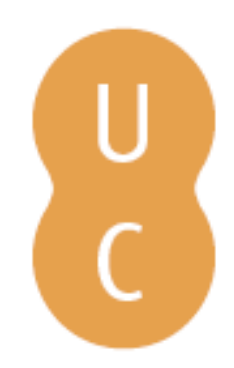

\title{
pompalina
}

\section{O pitagorismo como categoria historiográfica}

\author{
Autor(es): $\quad$ Cornelli, Gabriele
}

Publicado por: Centro de Estudos Clássicos e Humanísticos; Imprensa da Universidade

URL

persistente: URI:http://hdl.handle.net/10316.2/2382

DOI: $\quad$ DOI:http://dx.doi.org/10.14195/978-989-8281-96-8

Accessed : $\quad$ 26-Apr-2023 09:40:05

A navegação consulta e descarregamento dos títulos inseridos nas Bibliotecas Digitais UC Digitalis, UC Pombalina e UC Impactum, pressupõem a aceitação plena e sem reservas dos Termos e Condições de Uso destas Bibliotecas Digitais, disponíveis em https://digitalis.uc.pt/pt-pt/termos.

Conforme exposto nos referidos Termos e Condições de Uso, o descarregamento de títulos de acesso restrito requer uma licença válida de autorização devendo o utilizador aceder ao(s) documento(s) a partir de um endereço de IP da instituição detentora da supramencionada licença.

Ao utilizador é apenas permitido o descarregamento para uso pessoal, pelo que o emprego do(s) título(s) descarregado(s) para outro fim, designadamente comercial, carece de autorização do respetivo autor ou editor da obra.

Na medida em que todas as obras da UC Digitalis se encontram protegidas pelo Código do Direito de Autor e Direitos Conexos e demais legislação aplicável, toda a cópia, parcial ou total, deste documento, nos casos em que é legalmente admitida, deverá conter ou fazer-se acompanhar por este aviso.

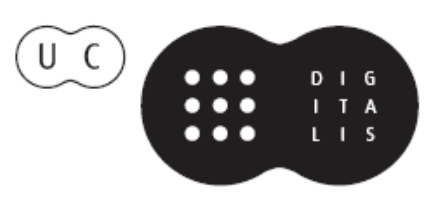




\section{O pitagorismo como categoria historiográfica}

Gabriele Cornelli 


\section{O pitagorismo como categoria historiográfica}

Gabriele Cornelli 
Todos os volumes desta série são sujeitos a arbitragem científica independente.

Autor

Gabriele Cornelli

Título

O pitagorismo como categoria historiográfica

EDitor

Centro de Estudos Clássicos e Humanísticos da Universidade de Coimbra

Imprensa da Universidade de Coimbra

EDIÇÃO:

1a/ 2011

Coordenador Científico do Plano de Edição

Maria do Céu Fialho

Conselho editorial

José Ribeiro Ferreira, Maria de Fátima Silva, Francisco de Oliveira e Nair Castro Soares

Director Técnico da Colecção:

Delfim F. Leão

Concepção Gráfica e Paginação:

Rodolfo Lopes, Nelson Ferreira

IMPRESSÃO:

Simões \& Linhares, Lda. Av. Fernando Namora, n. ${ }^{o} 83$ Loja 4. 3000 Coimbra

ISBN: 978-989-8281-95-1

ISBN DigITAL: 978-989-8281-96-8

Depósito LegAL: 331578/11

DOI: http://dx.doi.org/10.14195/978-989-8281-96-8

(C) IMPRENSA DA UNIVERISDADE DE COIMBRA

CCentro de Estudos Clássicos e Humanísticos da Universidade de Coimbra

(C) Classica Digitalia Vniversitatis Conimbrigensis (http://classicadigitalia.uc.pt)

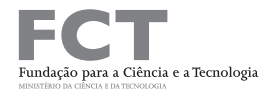

$\mathrm{POCI} / 2010$

Reservados todos os direitos. Nos termos legais fica expressamente proibida a reprodução total ou parcial por qualquer meio, em papel ou em edição eletrónica, sem autorização expressa dos titulares dos direitos. É desde já excecionada a utilização em circuitos académicos fechados para apoio a lecionação ou extensão cultural por via de e-learning. 


\section{SUMÁRIO}

Lista de Abreviações $\quad 7$

Apresentação

INTRODUÇÃo

$\begin{array}{ll}\text { Nota prévia } & 18\end{array}$

Agradecimentos $\quad 19$

Parte I. História da crítica: de Zeller a Kingsley

1.1 Zeller: o ceticismo dos começos 23

1.2 Diels: uma coleção "zelleriana” 30

1.3 Rohde: a reação ao ceticismo $\quad 32$

1.4 Burnet: o duplo ensinamento dos acusmáticos e matemáticos 34

1.5 Cornford e Guthrie: em busca da unidade entre ciência e religião 37

1.6 De Delatte a De Vogel: pitagorismo e política 42

1.7. O testemunho único de Aristóteles e a incerta tradição acadêmica 52

1.8 De Burkert a Kingsley: terceira-via e misticismo na tradição pitagórica 59

$\begin{array}{ll}1.9 \text { Conclusão } & 69\end{array}$

Parte II. O Pitagorismo como CATEgoria historiográfica

2.1 Interpretar interpretações: dimensão diacrônica e sincrônica 73

$\begin{array}{ll}2.2 \text { Identidade pitagórica } & 77\end{array}$

2.3 A koinonía pitagórica $\quad 83$

2.4 Acusmáticos e matemáticos 98

$\begin{array}{lr}2.5 \text { Conclusão } & 104\end{array}$

Parte III. Imortalidade dA Alma E Metempsicose

3.1 "É a alma?" (Xenófanes) 112

3.2 "Sábio mais do que todos" (Heráclito e Íon de Quios) 118

$\begin{array}{ll}3.3 \text { "Dez ou vinte gerações humanas" (Empédocles) } & 121\end{array}$

$\begin{array}{ll}3.4 \text { Platão e orfismo } & 123\end{array}$

3.4.1 "Compreender o lógos de seu ministério" 124

$\begin{array}{lr}\text { 3.4.2 Hierarquia das encarnações } & 129\end{array}$

$\begin{array}{lr}3.4 .3 \text { Sôma-sêma } & 130\end{array}$

$\begin{array}{ll}\text { 3.4.4 Mediação pitagórica } & 138\end{array}$

$\begin{array}{ll}3.5 \text { Heródoto, Isócrates e o Egito } & 143\end{array}$

$\begin{array}{ll}\text { 3.6 Lendas sobre a imortalidade } & 146\end{array}$

$\begin{array}{ll}3.7 \text { Demócrito pitagórico? } & 149\end{array}$ 
3.8 Aristóteles e os mitos pitagóricos 152

$\begin{array}{ll}3.9 \text { Conclusão } & 157\end{array}$

Parte IV. Números $\quad 159$

4.1 Tudo é número? $\quad 163$

4.1.1 Três versões da doutrina pitagórica dos números $\quad 163$

$\begin{array}{ll}\text { 4.1.2 Duas soluções } & 171\end{array}$

4.1.3 A "solução" filolaica $\quad 174$

4.1.3.1 Um livro ou três livros? 174

4.1.3.2 Autenticidade dos fragmentos de Filolau $\quad 176$

$\begin{array}{ll}\text { 4.1.3.3 A tradição pseudoepigráfica dórica } & 178\end{array}$

4.1.4 A exceção aristotélica (Met. A 6, 987b) 182

4.1.5 O testemunho platônico (Phlb. 16c-23c) 189

$\begin{array}{ll}4.2 \text { Os fragmentos de Filolau } & 195\end{array}$

4.2.1 Ilimitados/limitantes $\quad 195$

4.2.2 O papel dos números em Filolau 200

$\begin{array}{ll}4.3 \text { Conclusão } & 208\end{array}$

$\begin{array}{ll}\text { Conclusão } & 213\end{array}$

$\begin{array}{ll}\text { Bibliografia } & 223\end{array}$

Fontes Primárias 223

$\begin{array}{ll}\text { Fontes Secundárias } & 228\end{array}$

$\begin{array}{ll}\text { INDEX LOCORVM } & 247\end{array}$

$\begin{array}{ll}\text { INDEX NOMINVM } & 253\end{array}$

$\begin{array}{ll}\text { INDEX RERVM } & 259\end{array}$ 


\section{Lista DE ABREVIAÇões}

Ael. $=$ Aeliano

$\mathrm{aEC}=$ antes da Era Comum (= a.C.)

Aesch. $=$ Ésquilo

Anon. Phot. $=$ Anônimo de Fócio. Thesleff

Arist. $=$ Aristóteles

Crat. $=$ Platão. Crátilo

D. L. = Diógenes Laércio

De Abst.= Porfírio. A abstinência dos animais

De an. $=$ Aristóteles. De anima

De Comm. Mathem. = Jâmblico. De communi mathematica scientia

Diod. Sic. $=$ Diodoro Sículo

DK $=$ Diels-Kranz

$\mathrm{EC}=$ Era Comum $(=$ d.C. $)$

$\mathrm{EN}=$ Aristóteles. Ética Nicomaqueia

FGrHist $=$ Die Fragmente der Griechischen Historiker. Jacoby

Gell. $=$ Aulus Gellius, Noctes Atticae

Gorg. = Platão, Górgias

Herodt. $=$ Heródoto

Iambl. = Jâmblico

I1. $=$ Homero. Iliada

In Metaph. $=$ Alexandre de Afrodísia. Comentários sobre a Metafísica de Aristóteles

Leg. $=$ Platão. Leis

lit. = literalmente

Men. = Platão. Mênon

Met. $=$ Aristóteles. Metafísica

Metam. $=$ Ovídio. Metamorfoses

Mete. $=$ Aristóteles. Metereologica

$\mathrm{n}=$ nota

Od. $=$ Homero. Odisséi $i$

Orig. $=$ No original

P. Derv. $=$ Papiro Derveni

Phaed. = Platão. Fédon

Phaedr. $=$ Platão. Fedro

Phot. Bilb. = Biblioteca

Phlb. = Platão. Filebo

Phys. $=$ Aristóteles. Física

$\mathrm{PL}=$ Patrologia Latina. Migne

Porph. $=$ Porfírio

Procl. In Tim. = Proclo. Comentário ao Timeu

Prom. = Ésquilo. Prometeu

Resp. $=$ Platão. Repuiblica 
Retr. $=$ Agostinho. Retractationes

Schol. In Phaedr. = Escólios sobre o Fedro. Greene

Schol. In Soph. = Escólios sobre Sófocles. Elmsley

Soph. El. = Sófocles. Electra

Speusip. = Espeusipo

Stob. $=$ Estobeu. Anthologium

Syrian In Met. $=$ Siriano, Comentário à Metafísica de Aristóteles

Theophr. Met. $=$ Teofrasto. Metafísica

$\mathrm{VH}=$ Aeliano. Varia Historia

Vitae = Diógenes Laércio. Vidas e doutrinas dos filósofos ilustres

VP = Porfírio: Vida de Pitágoras ou Jâmblico: Vida Pitagórica 


\section{Apresentação}

Este trabalho não pretende ser, programaticamente, uma ulterior interpretação das doutrinas pitagóricas a acrescentar às muitíssimas interpretações já existentes. Parafraseando uma afirmação de Dodds a propósito dos Orficos, mas que se poderia retomar mesmo a propósito dos primeiros Pitagóricos, poder-se-ia afirmar, de facto, que quanto mais lemos sobre o assunto, menos o conhecemos. $\mathrm{O}$ trabalho de Cornelli, pelo contrário, se apresenta declaradamente como uma contribuição para o esclarecimento da "questão pitagórica", quer dizer, o autor segue os indícios da história das muitas interpretações que, desde a antiguidade, se sucederam na caracterização da complexa articulação do fenómeno do pitagorismo. Isto é o que Cornelli entende por compreensão do pitagorismo como "categoria historiográfica". O que não significa que, ao joeirar as diversas doutrinas pitagóricas no momento em que aparecem e quando determinam a imagem de um tipo de pitagorismo ou de outro, Cornelli não deixe de tomar uma posição própria. Posições com as quais quem escreve por vezes concorda, por vezes não. Mas isso é normal, no nosso campo de estudos. Aquilo com o qual se concorda absolutamente, creio, é quer a metodologia de abordagem dos vários problemas, quer aquela com que se enfrenta o estudo deles para chegar a eventuais soluções.

Portanto, o trabalho propõe-se como uma atenta apresentação das fontes primárias e das secundárias: as fontes primárias são muitíssimas, diria quase completas, e é riquíssimo o exame dos estudos historiográficos citados, que abarcam quase todas as tendências e interpretações do pitagorismo, de Zeller aos nossos dias. Neste "labirinto", Cornelli mostra saber orientar-se bem e possuir os instrumentos filológicos e filosóficos necessários para fazer isso. Naturalmente, parafraseando desta feita uma citação de Maria Timpanaro Cardini que Cornelli também usa, o seu trabalho, embora não seja definitivo (como, de resto, todos os nossos trabalhos), escapa a dois perigos das pesquisas 
deste gênero, isto é, não é inútil nem é insuficiente. Eu diria que o seu maior valor consiste precisamente em ter oferecido aos estudiosos do assunto um "mapa" inteligente e cuidadoso para nos orientarmos no labirinto da "questão pitagórica", dando-nos a possibilidade de enveredar por novos estudos sobre o assunto com uma maior consciência histórica e hermenêutica.

O trabalho está estruturado em quatro capítulos. O primeiro é dedicado precisamente à história da crítica, de Zeller aos nossos dias. Cornelli mostra que já na antiguidade se tinha colocado a questão espinhosa da autenticidade dos escritos atribuídos aos Pitagóricos, questão que, se com Iâmblico o fazia suplicar aos deuses que lhe dessem a capacidade de orientar-se, já no seu tempo, por entre a quantidade de escritos espúrios e "falsos" sobre a filosofia pitagórica, com Zeller o fazia pôr em dúvida a possibilidade mesma de falar da existência de um sistema pitagórico. Problemas antigos, portanto, que se apresentavam aos que enveredavam pelos estudos do pitagorismo. (Gostaria agora de observar, entre parênteses, que a existência destes problemas, além da sua precisa consciência, não impediu Jâmblico, nem Zeller, nem todos os estudiosos que enfrentaram o assunto, até mesmo Cornelli, de tomar uma posição específica quanto a ele, e de oferecerem uma interpretação própria do fenómeno do pitagorismo. Mas penso que isto é inevitável, porque se é verdade que o passado é por definição o que já não existe, as interpretações do passado sucedem-se e constituem o modo específico com o qual esse passado continua a existir). Cornelli reconstrói, portanto, a história destes problemas, começando pela famosa controvérsia sobre a distinção entre a dimensão religiosa e a dimensão científica presentes no primeiro pitagorismo, que de Burnet a Cornford até aos nossos dias continua a fazer discutir os estudiosos, e que viu emergir as soluções mais diversas, que ainda hoje se mostram dificilmente conciliáveis.

O segundo capítulo enfrenta precisamente a questão do pitagorismo como "categoria historiográfica" e ele é visto com a consciência da sua dupla dimensão, diacrônica e sincrónica. Cornelli está justamente da parte de quem se propõe superar as rígidas dicotomias de uma historiografia habituada a distinguir ciência de magia, ou escrita de oralidade. E com este método enfrenta questões importantes como o caráter elitista da "escola" pitagórica, a questão da vida em comum e da comunhão de bens, a questão da amizade, até chegar à famigerada distinção entre acusmáticos e matemáticos no interior da escola e, por conseguinte, à questão do "silêncio pitagórico". É precisamente do exame destas questões que Cornelli faz emergir as contradições que derivam da rígida aplicação daquelas dicotomias: Hípaso, por exemplo, era e é apresentado ou como acusmático ou como matemático. E a propósito desta última distinção, acho que talvez se possa concordar com Cornelli quando diz que ela não dizia respeito a dois graus distintos da afiliação à koinonía pitagórica, mas a dois grupos no interior do próprio movimento pitagórico. E este é precisamente um daqueles casos de que falava antes, isto é, de uma "tradição" consolidada, sim, mas que deve ser completamente interpretada com os nossos instrumentos hermenêuticos. 
O terceiro capítulo enfrenta um dos temas mais candentes da tradição pitagórica, o da imortalidade da alma e da metempsicose. Pessoalmente, reconheço,estou convencido de que este tema sempre foi tratado inevitavelmente partindo de convicções pessoais e próprias do intérprete, que em seguida reflete sobre os documentos antigos. É uma questão sobre a qual, mais do que sobre todas as outras, as posições dos intérpretes são decisivamente contrapostas e tenazmente defendidas com uma capacidade, para não dizer casmurrice, de encontrar nos antigos documentos suportes para a própria e pessoal perspetiva. Este é também o ponto sobre o qual as opiniões de quem escreve e as do Autor divergem; mas naturalmente este não é o momento para expor as minhas argumentações. Cornelli examina as fontes antigas, de Heraclito a Heródoto, até Platão e Aristóteles, para chegar a uma aceitação das duas doutrinas da imortalidade da alma e da metempsicose referidas aos primeiros Pitagóricos. Embora discorde pessoalmente das conclusões de Cornelli, quero realçar pelo menos um ponto sobre o qual não há desacordo, que é o destaque do sentido com o qual Platão se apropria de (segundo Cornelli), usa as (na minha opinião) doutrinas pitagóricas e as órficas, que é precisamente um sentido ético, com vista a uma refundação moral da vida humana.

O quarto capítulo diz respeito a outro aspeto importante das doutrinas pitagóricas, o dos números. Naturalmente os testemunhos mais importantes sobre este aspeto são os aristotélicos, que Cornelli examina de maneira crítica, juntamente com as mais importantes tomadas de posição historiográfica, como a de Cherniss, por exemplo. No âmbito deste problema o Autor enfrenta uma questão muito debatida hoje, a da autenticidade dos fragmentos de, e das informações sobre, Filolau de Crotona. Questão que Cornelli resolve positivamente, grosso modo, parece-me, na esteira das recentes e sólidas tomadas de posição historiográficas. Para chegar, por fim, a uma tese historiográfica própria e partilhável: Filolau não defende, ao contrário do que the atribui Aristóteles, que toda a realidade é número, mas - coerentemente com o que me parece ser uma conotação importante do primeiro pitagorismo - que a realidade é cognoscível através do número.

Concluindo, penso, como já disse, que este trabalho constitui uma utilíssima ferramenta para quem queira orientar-se com uma maior consciência histórica e hermenêutica na intrincada "questão pitagórica".

Giovanni Casertano (tradução de Maria da Graça Gomes de Pina) 


\section{INTRODUÇÃo}

Segundo Kahn (1974: 163), não são necessárias, em nossos dias, novas teorias sobre o pitagorismo.

Interpretações muito díspares acabaram, de fato, ao longo da história da crítica, por resultar em conclusões diversas e incompatíveis, ao ponto de Kahn sugerir que, no lugar de mais uma tese sobre o pitagorismo, seria preferível um trabalho de avaliação das tradições que pudesse resultar em uma boa apresentação historiográfica. ${ }^{1}$ Essa observação de Kahn, formulada há mais de trinta anos, orienta a presente opção por uma obra de marca fundamentalmente historiográfica e não filológica, isto é, que não se dedique exclusivamente à exegese de fontes como Filolau, Arquitas ou mesmo de uma das Vidas helenísticas, por exemplo; ou, ainda, à abordagem teorética de uma das temáticas que receberam a específica contribuição do pitagorismo, como matemática, cosmologia, política, teoria da alma. Assim, a presente monografia propõe-se a reconstituir a maneira como a tradição estabeleceu a imagem do pitagorismo.

Não que uma apresentação historiográfica não tenha em suas bases uma hermenêutica ou uma precompreensão teorética da filosofia pitagórica a partir de suas fontes. Todavia, a opção pela historiografia possui ao menos duas vantagens

${ }^{1} \mathrm{~A}$ oportunidade de voltar à tese de Kahn foi sugerida por Casertano, que se referiu a ela em seu mais recente livro sobre os pré-socráticos (Casertano 2009: 56). Cf. Kahn (1974: 163 n6): "It's hard enough to satisfy minimal standards of historical rigor in discussing the Pythagoreans, without introducing arbitrary guesswork of this sort where no two students can come to the same conclusion on the basis of the same evidence. In fact, the direct testimony for Pythagorean doctrines is all too abundant. The task for a serious scholarship is not to enrich these data by inventing new theories or unattested stages of development but to sift the evidence so as to determine which items are most worthy (or least unworthy) of belief”. O contexto próprio da observação de Kahn é aquele da crítica ao apriorismo, na reconstrução do pitagorismo a partir de evidências circunstanciais, de autores como Guthrie, conforme será discutido adiante (1.5). 
incontestáveis. A primeira delas diz respeito à postura necessariamente crítica e, até certo ponto, relativista que o trabalho historiográfico pressupõe. Esta postura está bem expressa por Luciano Canfora:

Trata-se de ter noção da constante e consubstancial relatividade do trabalho do historiador. Dependendo da distância do evento tratado, os historiadores fornecem um perfil e revelam faces cada vez diferentes: todas no fundo, de alguma maneira, verdadeiras e muitas vezes complementares entre elas: nenhuma exaustiva, como não seria exaustiva a soma mecânica de todas elas (Canfora 2002: 8-9). ${ }^{2}$

A primeira vantagem da abordagem historiográfica ao pitagorismo é, portanto, aquela da tomada de consciência inicial do fato que nenhuma das teses sobre o pitagorismo poderá ser exaustiva - nas palavras de Canfora-, deixando assim, de certo modo, as mãos livres para uma articulação historiográfica que possa apresentar o pitagorismo em sua complexa diversidade. Talvez seja este o maior problema da monografia mais recente sobre o pitagorismo, escrita por Riedweg (2002), e justamente criticada, nesse sentido, por Huffman (2008a): trata-se de uma abordagem geral ao pitagorismo que se alinha a uma ou outra interpretação global do movimento. Pode seguir, em sentido mais místicoreligioso, por exemplo, Detienne (1962; 1963), Burkert (1972) e Kingsley (1995) ou, em perspectiva mais política, Von Fritz (1940) e Minar (1942). Contudo, se esquece de dar conta daquela que é talvez a questão fundamental: a presença de uma história da interpretação que, já na antiguidade - basta ver o prólogo da Vida Pitagórica, de Jâmblico -, quis reunir experiências e doutrinas totalmente diversas (quando não mesmo contraditórias) na categoria historiográfica do pitagorismo. Dessa forma, pensar o pitagorismo como categoria historiográfica significa, antes de tudo, superar metodologicamente a ilusão da possibilidade de alcançar a coisa em si, a história verdadeira, aceitando confrontar-se conscientemente com a necessária mediação representada por quem a escreve a cada momento.

A segunda vantagem comparativa de uma abordagem historiográfica, no lugar do desenvolvimento de mais uma interpretação dessa filosofia, diz respeito a um dos problemas centrais que caracterizam o pitagorismo quando comparado com outros movimentos filosóficos do mundo antigo: aquele do terreno especialmente movediço da crítica das fontes. É certamente o caso de enfrentar, ao longo desta obra, com renovado esforço interpretativo e filológico, a questão central da expansão da tradição, de zelleriana memória, e a deriva cética que esta impõe normalmente aos comentadores.

A vantagem de uma abordagem historiográfica é aquela, portanto, de tentar abraçar o pitagorismo em sua totalidade, isto é, abordando a problemática

2 Orig.: "Si tratta di prendere nozione della costante e consustanziale relatività del mestiere dello storico. A seconda della distanza dall'evento trattato, gli storici ne danno um profilo e ne rileveranno delle facce volta a volta differenti: tutte in fondo in qualche modo vere, e spesso tra loro complementari: nessuna esaustiva, come esaustiva non sarebbe neanche la meccanica somma di tutte queste facce". 
de suas fontes para poder compreendê-lo por meio de, e não apesar de sua complexa articulação ao longo de mais de um milênio de história da filosofia antiga. Ainda que essa perspectiva tenha sido de fato inaugurada por Burnet (1908), e depois reafirmada por Cornford (1922; 1923) e Guthrie (1962), é possível encontrar uma abordagem especialmente compreensiva sobretudo na tradição historiográfica italiana sobre o pitagorismo, inaugurada por autores clássicos como Rostagni (1922) e Mondolfo (na edição revista e comentada de Zeller, 1938). O problema das fontes pré-socráticas (mas não somente delas, veja-se o caso da traditio dos próprios textos de Platão e Aristóteles, nesse sentido), que se baseia em sua elaboração tardia, assume, diante da expansão da tradição pitagórica, conotação de especial dramaticidade. Se é verdade - como demonstra, de forma convincente, Burkert (1972: 15-96) - que a existência de uma filosofia pitagórica depende em larga medida da invenção de uma vulgata pitagórica (pesadamente transfigurada) por parte dos acadêmicos; e, ainda, se é provável que os assim chamados pitagóricos de Aristóteles sejam fundamentalmente filósofos como Filolau, ou seja, uma segunda (ou terceira) geração do movimento; é, então, certamente o caso de perguntar-se o que as fontes mais tardias teriam para nos dizer de historicamente confiável sobre o protopitagorismo, isto é, sobre aquele momento inaugural do desenvolvimento da tradição do pitagorismo que corresponde a Pitágoras e seus primeiros discípulos. ${ }^{3}$ Contudo, é, ainda, o caso de perguntar-se se seria possível falar algo deste sem as três Vidas (bem posteriores, com quase um milênio de diferença) de Diógenes Laércio, Porfírio e Jâmblico.

Procedem, nesse sentido, as dúvidas de Zhmud:

Por que as diferenças doutrinárias são tão grandes no pitagorismo? Primeiramente, porque ele não surgiu como uma escola filosófica, e, portanto, não foi jamais fundamental o seguir a totalidade de determinadas doutrinas (Zhmud 1989: 289). ${ }^{4}$

Como também é possível concluir, com Centrone (1996: 91), que o pitagorismo antigo seria uma associação fundada sobre particular estilo de vida, seguindo as regras de um bios específico, expressas por akouismata, fundamentalmente escatológicos.

No entanto, esta koinonía de vida foi reconhecida pela filosofia já antiga (veja-se Xenófanes e Heráclito) como referência de uma maneira de fazer filosofia e identificada por uma complexa série (ainda que nem sempre coerente, como será visto) de personagens e ensinamentos que passaram a

\footnotetext{
${ }^{3}$ Introduz-se, aqui, de forma inédita, o termo protopitagorismo, por considerar-se necessária uma distinção entre esse primeiro momento, fundador do pitagorismo, e um segundo momento, de elaboração do pitagorismo ao longo do V século aEC, ainda "pré-socrático", que se utiliza da escrita e corresponde ao estágio das fontes imediatas de Platão e Aristóteles. Para os modos de utilização e o sentido do uso do termo análogo protofilosofia, cf. Boas (1948: 673-684).

${ }^{4}$ Orig.: "Why are the doctrinal differences so great in Pythagoreanism? First of all, because it had not arisen as a philosophic school, and belonging to it had never been determined by following the sum of certain doctrines".
} 
ser chamados de pitagóricos; isto é, o termo pitagorismo foi associado a uma filosofia também, não apenas a um estilo de vida.

É sobretudo esta identificação da categoria "pitagórico" que atrai a atenção do historiador da filosofia. Por esses motivos, portanto, uma discussão historiográfica será o objetivo da presente monografia.

$\mathrm{O}$ esforço por traçar um perfil inclusivo e compreensivo das condições e das possibilidades de definir-se o que seja pitagorismo ou pitagórico, no interior de um movimento filosófico de tamanha amplidão histórica e teorética, acaba por confundir-se com a intenção de contribuir metodologicamente para uma revisão historiográfica da filosofia antiga em geral; pois compreender esse movimento é determinante para a compreensão das origens da filosofia e, de forma mais geral, do pensamento ocidental. Os elementos sensíveis da historiografia do pitagorismo tornam-no um locus privilegiado para um exercício que almeja alcance historiográfico maior e que se encontra nas entrelinhas da presente obra.

Uma boa apresentação historiográfica tratará, assim, de fazer emergir dos arquivos da história da interpretação do pitagorismo os pontos sensíveis que contribuíram para a formação de tantas e diversas lectiones sobre o pitagorismo. É mister concordar com Huffman quando afirma que "o pitagorismo é uma área de estudo repleta de tópicos controvertidos" (Huffman 2008b: 225). ${ }^{5}$ Ao mesmo tempo, todavia, não é correto conjecturar que a imagem multifacetada do pitagorismo, conforme se apresenta ao longo da história da tradição, possa derivar simplesmente de uma série de acidentes de percurso, que teriam transformado uma imagem pretensamente homogênea em suas origens em um conjunto poliédrico de doutrinas e personagens.

O próprio Burkert afirma isso no Prefácio à edição alemã de sua obra fundamental sobre o pitagorismo, Lore and Science in Ancient Pythagoreanism:

Se Pitágoras não se apresenta às nossas mentes como uma figura bem delineada, em pé na luz brilhante da história, isto não é simplesmente o resultado de acidentes ao longo do percurso da tradição histórica (Burkert 1972: Prefácio à edição alemã). ${ }^{6}$

Ao contrário, essa imagem é o resultado de escolhas historiográficas bem precisas e que obedecem, a cada momento, à compreensão do que era a filosofia em suas origens (em perspectiva genealógica) e, por consequência, do que é a filosofia desde suas origens (em perspectiva histórica). Desde o prólogo da Vida Pitagórica, de Jâmblico (Iambl. VP: 1), até às Lições sobre história da filosofia, de Hegel, e às recentes interpretações de Kingsley (1995), é possível confrontar-se com as precompreensões que levaram a privilegiar esta ou aquela imagem e a resolver de uma ou outra forma a questão pitagórica (Burkert 1972: I).

\footnotetext{
${ }^{5}$ Orig.: "Pythagoreanism is an area of study that is full of controversial issues".

${ }^{6}$ Orig.: "If Pythagoras does not present himself to our minds as a sharply outlined figure, standing in the bright light of history, this is not merely the result of accidents in the course of historical transmission".
} 
Esta obra pretende, portanto, acompanhar o percurso dessas escolhas, verificando onde for possível seus pressupostos e revelando as consequências destas para a interpretação, não somente de algumas temáticas centrais, mas especialmente da própria construção do pitagorismo como categoria.

O Capitulo Primeiro será, portanto, dedicado à compreensão das linhas mestras que definiram, durante especialmente os últimos dois séculos, o quadro geral da moderna história da crítica sobre o pitagorismo. A imagem da ciência que deste resultará é a de uma intricada sucessão de controvérsias e refutações, na alternância entre ceticismo e confiança nas fontes que marca a crítica da tradição sobre a filosofia antiga como tal. A dificuldade fundamental, que emerge ao longo da história das interpretações, da poliedricidade do fenômeno estudado, indicará a necessidade de cuidados metodológicos que conscientemente permitam descrevê-lo como tal, em sua irreduzível diversidade.

O Capitulo Segundo, com a intenção de resolver as dificuldades acima indicadas, explorará as modalidades da definição do pitagorismo como uma categoria historiográfica. Começando pela definição de duas dimensões, uma sincrônica e outra diacrônica, que, imbricadas entre elas, permitam descrever um fenômeno de outra forma incompreensível em sua diversidade, chega-se à discussão dos critérios de identificação do pitagórico e da comunidade pitagórica. Ainda que com a consciência de que o quebra-cabeça hermenêutico das tradições sobre o pitagorismo ficará sempre inacabado, será proposto um caminho por meio das duas temáticas que mais decididamente contribuíram para a definição da categoria pitagorismo ao longo da história da tradição: metempsicose e matemática. A intenção desta análise será, por um lado, verificar a possibilidade de atribuição da origem das duas temáticas ao protopitagorismo e o pitagorismo do século V a.C; por outro, a de sinalizar de que maneira essas temáticas colaboraram para a categorização do pitagorismo ao longo da história da tradição.

O Capitulo Terceiro, portanto, enfrentará as tradições sobre a imortalidade da alma e sua transmigração. A análise considerará tanto testemunhos flosóficos pré-socráticos, platônicos e aristotélicos como outras tipologias de fontes antigas: entre elas, Heródoto, a literatura órfica, recentes documentos arqueológicos e a tradição das lendas sobre as viagens ao além-túmulo. A tradição pitagórica será encontrada em um lugar intermediário entre as teorias da imortalidade órficas e a reelaboração que destas faz a filosofia dos séculos $\mathrm{V}$ e IV a.C, notadamente Platão. Na referência de Aristóteles aos mitos pitagóricos, será reconhecido o testemunho mais sólido da existência de uma teoria protopitagórica da imortalidade da alma.

O Capitulo Quarto, partindo da constatação de que comumente a matemática e o interesse pelos números têm sido atribuídos como características fundamentais da filosofia pitagórica, submeterá tais tradições a uma revisão historiográfica. Como no capítulo terceiro, a análise do testemunho de Aristóteles será decisiva. A afirmação dele pela qual para os pitagóricos "tudo 
é número" será considerada como, ao mesmo tempo, fonte da matemática do pitagorismo antigo e testemunho do amplo processo de recepção desta em âmbito acadêmico. Novamente aparecerá decisiva, portanto, a reelaboração acadêmica das doutrinas pitagóricas. Todavia, Aristóteles demonstrará certa independência desta última, fundamentalmente graças ao fato de ele poder atingir as fontes pré-socráticas independentes, que nomeia enigmaticamente como os "assim chamados pitagóricos". Será demonstrado que essas fontes correspondem fundamentalmente aos fragmentos de Filolau. A "questão filolaica", portanto, será enfrentada a partir da análise comparativa entre uma célebre página da Metafísica $A$, algumas páginas do Filebo e o próprio livro de Filolau. Resultará dessa uma confirmação, por um lado, da possibilidade de atribuição de uma teoria numérica, senão ao protopitagorismo, ao menos ao pitagorismo do século $\mathrm{V}$ aEC; por outro lado, mais uma vez, da influência determinante da (quase) onipresente mediação acadêmica sobre a categorização da filosofia pitagórica.

\section{Nota prévia}

Antes de adentrar propriamente na leitura desta obra,fazem-se necessárias algumas observações sobre sua apresentação. Para facilitar a leitura, o corpo do texto é integralmente em língua portuguesa. Optou-se por sempre transliterar, no corpo do texto, os termos gregos, conforme o padrão internacional ISO 843:1997; utiliza-se o alfabeto grego somente nas notas; assim como, nas mesmas notas, mantêm-se as citações de autores modernos em língua original. Em muitos casos optou-se por reproduzir, em notas, o texto original do autor citado, por causa do difícil acesso a uma bibliografia muito especializada. Optou-se para, em geral, não fazer o mesmo com as passagens gregas das obras de maior uso: o acesso às mesmas é de fato hoje quase que universal, graças ao Thesaurus e outras ferramentas digitais. A grafia de nomes gregos e romanos segue, sempre que possível, o Vocabulário Onomástico de Caldas Aulete (1958). Todas as traduções são minhas, salvo explícitas indicações em contrário. As normas de referências bibliográficas utilizadas são aquela do sistema de Harvard. O texto foi revisado e está em conformidade com o Acordo Ortográfico da Lingua Portuguesa (2009). 


\section{Agradecimentos}

A presente obra é resultado de quase uma década de pesquisas, que acabou confluindo numa tese doutoral, defendida no Programa de Pós-Graduação em Filosofia da Universidade de São Paulo, em Setembro de 2010. Grande parte da presente obra deriva daquela. Agradeço, por este motivo, a generosa acolhida de Roberto Bolzani Filho. Ao longo destes anos diversos colegas, das mais variadas formas, contribuíram para o aprimoramento desta monografia. De maneira especial os amigos Gianni Casertano, André Chevitarese e Marcelo Carvalho; como também Alberto Bernabé, Bruno Centrone, Carl Huffman, Christoph Riedweg, Dennys Garcia Xavier, Edrisi Fernandes, Emmanuele Vimercati, Fernando Rey Puente, Fernando Santoro, Francisco Lisi, Franco Trabattoni, Gerson Brea, Hector Benoit, José Gabriel Trindade Santos, Laura Gemelli Marciano, Livio Rossetti, Luc Brisson, Constatinos Macris, Marcelo Perine, Marcus Mota, Maurizio Migliori, Miriam Campolina Peixoto, Pedro Paulo Funari, Rachel Gazolla, Thomas Szlezák, Tom Robinson, que tiveram a gentileza de discutir comigo, em diversas circunstâncias, partes da pesquisa que originou esta obra. Devo um agradecimento especial também aos alunos do Archai, que com sua dedicação e entusiasmo ainda me surpreendem e confirmam as razões de minha paixão pela filosofia antiga. Ao Departamento de Filosofia da Universidade de Brasília, que me concedeu o tempo necessário para concluir este projeto, e um lugar onde poder compartilhá-lo. A CAPES e ao CNPq, que me permitiram ter acesso a quase toda a bibliografia relevante sobre o tema, além de realizar alguns estágios de pesquisa. À Maria do Céu Fialho e ao Delfim Leão, do Centro de Estudos Clássicos e Humanísticos da Universidade de Coimbra, por acolher esta obra em sua preciosa Coleção Classica Digitalia.

Um agradecimento especial merecem Maria da Graça Gomes de Pina e Edrisi Fernandes e Jonatas R. Alvares por contribuírem significativamente na preparação final do texto. 
Agradeço, enfim, especialmente, a paciência e ao abraço de quem divide comigo a vida: Monique. Por mostrar-me todo dia, com doçura e força, que metade é uma medida que se supera.

Obrigado. 


\section{Parte I}

História dA CRÍtica: DE Zeller A KingSLEY 
$\mathrm{Na}$ labiríntica confusão da tradição da sabedoria pitagórica e da sociedade pitagórica que, em grande parte, nos foi transmitida por escritores e compiladores tardios e ingênuos, como que encoberta por uma sagrada escuridão, os fragmentos de Filolau sempre representaram para mim como um ponto cintilante. ${ }^{1}$

(Boeckh 1819: 3)

Assim principia Boeckh, em 1819, a obra que marca a pré-história da crítica moderna sobre o pitagorismo. Um incipit altamente significativo, especialmente quando considerado, em perspectiva, à luz dos dois séculos de interpretação que a ele se sucederam e que desenham o sinuoso percurso da história da tradição moderna sobre o pitagorismo. Um início que revela com precisão dois dos maiores loci hermenêuticos da crítica: de um lado, pela expressão labyrintischen Gewirre, a significar inconfundivelmente a opinião comum da grande dificuldade de assimilação da literatura pitagórica; por outro lado, pela imediata individuação de um lichter Punkt, um "ponto cintilante" em alguma parte desta (e que corresponde geralmente a um autor ou uma temática específica) que possa iluminar a escuridão do labirinto historiográfico: um fio de Ariadne, que permita sair da "confusão" com a qual o historiador do pitagorismo é tradicionalmente levado a confrontar-se.

A percepção dessa mesma dificuldade não é exclusiva da crítica moderna: Jâmblico, também logo no início de sua Vida Pitagórica, apelava para os deuses, com o objetivo expresso de solicitar que o assistissem na difícil empreitada de superar dois obstáculos para o desenvolvimento de sua biografia histórica: de um lado, a estranheza das doutrinas e a obscuridade dos símbolos; do outro, a quantidade de escritos espúrios e mentirosos sobre a filosofia pitagórica que circularam até então:

No começo de toda filosofia, é costume dos sábios apelar para um deus; isso vale ainda mais para aquela filosofia que, pelo que parece, leva justamente o nome do divino Pitágoras. Esta de fato foi concedida desde o início pelos deuses e não é possível compreendê-la se não com a ajuda deles. Além disso, sua beleza e sua grandeza superam as capacidades humanas, de maneira que é impossível abraçá-la imediatamente e com um único olhar. Portanto, somente se um deus benigno nos guiar será possível aproximar-se lentamente dela e gradativamente apropriar-se de alguma parte. Por todas estas razões, após ter

${ }^{1}$ Orig.: Im dem labyrinthischen Gewirre der Uberlieferungen über die Pythagorische Weisheit und Pythagorische Gesellschaft, welche großentheils durch späte und urtheilslose Schriftsteller und Zusammenträger wie in heiliges Dunkel gehüllt zu uns herübergekommen sind, haben des Philolaos Brüchstüke sich mir immer als ein lichter Punkt dargestellt”. 
invocado os deuses como nossos guias e confiado a eles nós mesmos e nosso discurso, vamos segui-los aonde eles nos queiram conduzir. Não devemos dar importância ao fato de que esta escola de pensamento, há algum tempo, encontra-se abandonada, nem da estranheza das doutrinas e da obscuridade dos símbolos nos quais ela está envolvida, nem dos muitos escritos falsos e apócrifos que lançaram sombras sobre ela, nem das muitas dificuldades que tornam o acesso a ela árduo (Iambl. VP: 1).

Uma sensação de pânico labiríntico parece acompanhar, portanto, desde os albores dessa história, o encontro do historiador com o pitagorismo. A ela segue, da mesma forma, uma imediata tentativa de sair do labirinto, de achar uma ordem no caos, de individuar uma constante que permita ao discurso historiográfico alcançar certa estabilidade hermenêutica.

Os dois séculos que se seguiram à obra inaugural de Boeckh sobre Filolau constituem o objeto principal das páginas a seguir. ${ }^{2} \mathrm{~A}$ intenção é a de acompanhar o proceder - nem sempre calmo e arrazoado - da crítica, sabendo de antemão que resultará deste uma história em que cada fato e cada testemunho serão colocados em discussão, à exceção, provavelmente, da própria existência dos assim chamados pitagóricos: "na controvérsia acadêmica que seguiu dificilmente um único fato permaneceu indisputado, com a exceção de que nos dias de Platão e, mais tarde, no primeiro século a.C, existiram Pythagoreioi" (Burkert 1972: 2). ${ }^{3}$

Apesar disso, será possível revelar sinais de continuidade de uma lectio do pitagorismo que o entregará à história com as características de um movimento especial, complexo e de difícil interpretação no interior do panorama dos estudos normais (no sentido kubniano) da filosofia pré-socrática.

Obviamente, o pitagorismo compartilha o ponto de partida da moderna história de sua crítica com o restante da filosofia grega antiga. Nesse caso, o precursor é certamente Zeller, que, em sua Die Philosophie der Griechen in ihrer geschichtlichen Entwicklung (1855), traça as bases para a moderna historiografia da filosofia antiga.

${ }^{2}$ É preciso notar que a maioria dos comentadores (Thesleff 1961: 31; De Vogel 1966: 8; Burkert 1972: 2; Centrone 1996: 193) não considera a obra de Boeckh (1819) como inaugural da história da crítica do pitagorismo, preferindo fazê-la começar mais tradicionalmente com a obra de Zeller (1855; esta obra será citada daqui para frente na edição italiana complementada e anotada por Mondolfo, em 1938).

${ }^{3}$ Orig.: "In the scholarly controversy that followed scarcely a single fact remained undisputed, save that in Plato's day and then later, in the first century B.C., there were Pythagoreioi". 


\subsection{ZELLER: O CETICISMO DOS COMEÇOS}

Significativamente, a primeira página do capítulo de Zeller dedicada ao pitagorismo põe-se em continuidade com os textos de Jâmblico e Boeckh anteriormente citados, indicando especial dificuldade para o estudo do pitagorismo na mistura de fábulas e poesias que teria encoberto a doutrina filosófica:

Entre todas as escolas filosóficas das quais temos conhecimento não há nenhuma cuja história não tenha sido frequentemente envolvida e quase encoberta por fábulas e poesias, e cuja doutrina não tenha sido mesclada na tradição com uma quantidade enorme de elementos posteriores, como foi aquela dos pitagóricos (Zeller e Mondolfo 1938: 288). ${ }^{4}$

Zeller enfrenta o problema, por assim dizer, de peito, perguntando-se imediatamente sobre a própria possibilidade de existência de um sistema filosófico pitagórico: "poderia se levantar a questão seria o caso de falar em geral do sistema pitagórico como de um complexo científico e histórico" (Zeller e Mondolfo 1938: 597).

A dúvida é potencialmente paralizadora, pois coloca em cheque a própria possibilidade de abordagem do pitagorismo no interior daquelas que se convém considerar Histórias da Filosofia. $\mathrm{O}$ risco, a dizer de Zeller, é que o pitagorismo, a bem ver, não seja outra coisa senão uma selva de mitos e ritos estranhos, sem alguma relevância para a filosofia. Por sorte, a resposta de Zeller é positiva: "tudo aquilo que nos é transmitido com relação à filosofia pitagórica, ainda que entre todas as divergências de determinações subordinadas, ainda coincide nos traços fundamentais" (1938: 599).6 Isto é, há, no pitagorismo, algo de filosófico que poderá ser salvo para futura sistematização.

Para realizar essa salvação in principio do pitagorismo, todavia,Zeller precisa operar historiograficamente de forma decididamente desenvolvimentista, para não dizer positivista, aplicando sobre esse movimento, com a precisão cirúrgica do erudito alemão do século XIX, um rí́ido esquema historicista. Para que esse esquema possa funcionar, Zeller precisa criar diversos gaps hermenêuticos, várias fraturas controladas com precisão e bem demarcadas. De maneira especial, é possível observar, no interior da estratégia zelleriana de salvação do pitagorismo, a operacionalização de três fraturas, realizadas: a) entre a maioria das fontes e dos testemunhos do pitagorismo, que são tardios, notadamente

${ }^{4}$ Orig.: "Fra tutte le scuole filosofiche che noi conosciamo non ve n’è alcuna, la cui storia non sia stata tanto spesso avvolta e quasi coperta di favole e poesie, e la cui dottrina sia stata mescolata nella tradizione con una tal massa di elementi posteriori, quanto quella dei Pitagorici".

${ }^{5}$ Orig.: "Si potrebbe sollevare la questione se sia il caso di parlare in genere del sistema pitagorico come di un complesso scientifico e storico".

${ }^{6}$ Orig.: "Tutto ciò che ci è riferito della filosofia pitagorica, pur fra tutte le divergenze di determinazioni subordinate, coincide tuttavia nei tratti fondamentali”. 
neopitagóricos, de um lado, e as origens da filosofia pitagórica do outro; b) entre a doutrina filosófico-científica e outras formas de expressão míticoreligiosas; c) entre cultura grega e cultura oriental, para que o pitagorismo possa resultar como um movimento genuinamente grego.

Dessa forma, para resolver a questão das fontes, Zeller elabora a célebre teoria da expansão da tradição, a qual observa como, com o passar do tempo, as fontes sobre o pitagorismo, em vez de diminuir - como era de se esperar -, aumentam:

Dessa forma, a tradição relativa ao pitagorismo e ao seu fundador consegue nos dizer tanto mais quanto mais se encontre distante no tempo dos respectivos fatos históricos, e, ao contrário, ela se encontra na mesma proporção tanto mais silenciosa na medida em que nos aproximamos cronologicamente a seu mesmo objeto (Zeller e Mondolfo 1938: 299). ${ }^{7}$

Zeller pode assim concluir que "a pretensa doutrina pitagórica que não é recebida pelos testemunhos mais antigos, é neopitagórica" (1938: 300). ${ }^{8}$ Isto é, utilizando-se de um argumento, de certa forma circular, e recusando-se a uma distinção mais cuidadosa do material relevante no interior da literatura pitagórica tardia, pretende fundar o que é pitagórico exclusivamente sobre os testemunhos por ele considerados como os mais antigos. Entre eles, Zeller privilegiará Aristóteles e os fragmentos de Filolau, que, na esteira do Boeckh considera, em bloco, como autênticos. ${ }^{9}$

Por consequência da escolha acima, o material mais relevante para a história do pitagorismo é aquele que o aproxima e o identifica com os outros sistemas pré-socráticos e que diz respeito à filosofia da natureza:

O objeto da ciência pitagórica, na base de tudo o que foi dito até este momento, resulta aquele mesmo do qual se ocupavam todos os outros sistemas da filosofia pré-socrática, isto é os fenômenos naturais e seus princípios (Zeller e Mondolfo 1938: 585). ${ }^{10}$

${ }^{7}$ Orig.: "Cosí dunque la tradizione riguardante il Pitagorismo ed il suo fondatore ci sa dire tanto di più quanto più si trovi lontana nel tempo dai relativi fatti storici, e per contro essa è nella stessa proporzione tanto più taciturna a misura che ci avviciniamo cronologicamente al suo oggetto medesimo".

8 Orig.: "la pretesa dottrina pitagorica, che non è conosciuta dai testimoni più antichi, è neopitagorica”.

${ }_{9}^{9}$ Cf. a ampla discussão da nota 2 da p. 304. Na mesma nota, todavia (p. 307), Zeller afasta-se de Boeckh em relação à autenticidade do fragmento sobre a alma-mundo (44 B21 DK), por considerar estranha a Filolau uma teoria da alma dividida em diversas partes, como aquela expressa na tradição platônico-aristotélica. Com ele concordarão em seguida Burkert (1972: 242-243) e Huffman (1993: 343). Cf. Cornelli (2002) para mais ampla discussão da teoria zelleriana da expansão da tradição.

${ }^{10}$ Orig.: "L'oggetto della scienza pitagorica, in base a tutto ciò che si è detto fin qui, risulta quel medesimo di cui si occupavano tutti gli altri sistemi della filosofia presocratica, vale a dire i fenomeni naturali e i loro principi”. 
Com base nesses critérios temáticos, portanto, Zeller, em argumento circular, acaba por definir quais sejam os testemunhos válidos para uma história do pitagorismo em suas origens. Da mesma maneira, excluindo por parti pris a consideração das doutrinas míticas do pitagorismo, Zeller não pode senão declarar adesão irrestrita a Aristóteles e seu juízo sobre os pitagóricos:

Não podem ser aqui tomadas em consideração às doutrinas míticas da transmigração das almas e da visão da vida fundada sobre esta: estes são dogmas religiosos, que além do mais não eram exclusivos da escola pitagórica, e não proposições científicas. Por aquilo que diz respeito à filosofia pitagórica, eu posso somente concordar com o juízo de Aristóteles, que ela tenha se consagrado inteiramente à pesquisa natural (Zeller e Mondolfo 1938: 585-587). ${ }^{11}$

Mais especificamente, se não for possível verificar com precisão quanto do pitagorismo do século V a.C (Filolau, Arquitas) possa ser referido ao próprio Pitágoras, Zeller sugere, contudo, que as principais doutrinas devam derivar diretamente dele: in primis a doutrina de "tudo é número", "que constitui o caráter diferencial mais geral da filosofia pitagórica" e que pode se resumir na afirmação pela qual "o número é a essência de todas as coisas, ou seja, que tudo, em sua essência, seja número" (Zeller e Mondolfo 1938: 435). ${ }^{12}$ Da mesma forma, devem ser atribuídas a Pitágoras as doutrinas da harmonia, do fogo central e a teoria das esferas: todas elas presentes nos fragmentos de Filolau, que - como vimos - eram considerados autênticos por Zeller.

$\mathrm{Na}$ mesma linha, Zeller, apesar de demonstrar conhecer bem tanto os testemunhos antigos quanto os estudos orientalistas alemães a ele contemporâneos, os mesmos que aproximam a filosofia grega em geral, e o pitagorismo em especial, às tradições de pensamento egípcias, persas e indianas, ainda assim intitula o capítulo dedicado a este tema, de maneira incontrovertida, Contra a Origem Oriental. Zeller declara imediatamente a improbabilidade de uma origem oriental das doutrinas (Zeller e Mondolfo 1938: 602-606) e aposta, ao contrário, nas origens gregas do pitagorismo e na possibilidade de "compreendê-lo perfeitamente com base nas característias próprias e nas condições de cultura do povo grego no século VI a.C" (Zeller e Mondolfo 1938: 607). ${ }^{13}$ O pitagorismo será, portanto, compreendido como parte de um movimento maior de reforma moral e religiosa, do qual fazem parte figuras como Epimênides, os poetas gnômicos, os sete sábios; ainda que se eleve acima destes outros pela "poliedricidade e a potência com a qual ele

11 Orig.: "Non possono essere qui prese in considerazione le dottrine mitiche della transmigrazione delle anime e della visione della vita fondata sopra di essa: questi sono dogmi religiosi, che oltre tutto non eran limitati alla scuola pitagorica, e non sono proposizioni scientifiche. Per ciò che riguarda la filosofia pitagorica, io posso soltanto associarmi al giudizio di Aristotele, che essa sia stata consacrata tutta quanta alla ricerca naturale”.

${ }^{12}$ Orig.: "che constituisce il carattere differenziale più generale della filosofia pitagórica" e "il numero sia l'essenza di tutte le cose, ossia che tutto di sua essenza sia numero".

${ }^{13}$ Orig.: "comprender[lo] perfettamente sulla base delle caratteristiche proprie e delle condizioni di cultura del popolo greco nel VI secolo a. C.”. 
abraçou dentro de si a inteira substância da cultura de seu tempo, o elemento religioso, o ético-político, e o científico" (1938: 607). ${ }^{14}$

O esforço de Zeller no sentido de separar o pitagorismo de possíveis relações perigosas com o Oriente obriga-o a fazer derivar a matemática pitagórica de Anaximandro: "aos estudos matemáticos, dificilmente podia ter sido introduzido naquele tempo por alguma outra pessoa" (1938: 609); $;^{15}$ assim como a negar qualquer influência dos povos itálicos autóctones, anteriores à colonização dórica, que sem nenhum pudor chama de bárbaros (1938: 610-611). ${ }^{16}$ Insere-se neste mesmo projeto a insistência na profunda relação da Magna Grécia com aquele que Zeller chama de "caráter próprio da estirpe dórica", do qual dependeriam as instituições das cidades dórico-aqueias que foram palco da atividade de Pitágoras (1938: 607). Como exemplos desse caráter Zeller enumera, entre outros: a política aristocrática, a música ética, a sabedoria enigmática, a participação das mulheres na educação e na sociedade, a firme doutrina moral toda baseada na medida e que não conhece nada de mais alto do que a subordinação dos indivíduos ao todo, o respeito pelos genitores, pela autoridade e pela velhice (1938: 608-609). ${ }^{17}$ Com uma impostação historiográfica como esta, marcadamente hegeliana (vejam-se deste, nesse sentido, as Licções sobre a História da Filosofia), a conclusão não poderia ser outra senão aquela de um argumento circular e a posteriori da supremacia grega (e pitagórica): a prova da superioridade do caráter dos povos da Magna Grécia é que ali surgiu a filosofia: "o terreno que a filosofia encontrou para si nas colônias da Magna Grécia era a tal ponto favorável. A flor à qual ela pôde chegar é a prova disso" (1938: 611)..$^{18}$

Vale, portanto, também para Zeller, aquilo pelo que, mais recentemente, Centrone chamava a atenção de Zhmud e que, de certa forma, é um leitmotiv de toda história da crítica filosófica, não somente pré-socrática: tem-se sempre a impressão de que o historiador acha no autor clássico estudado a figura de si mesmo ou de suas afinidades eletivas:

Tem-se a impressão que, por uma feliz coincidência, a imagem de Pitágoras reconstruída por Zhmud, o mais possível depurada das componentes religiosas

${ }^{14}$ Orig.: "poliedricità e la potenza, con cui esso ha abbracciato entro di sè tutta quanta la sostanza della cultura del suo tempo, l'elemento religioso, quello etico-politico, e quello scientifico".

15 Orig.: "agli studi matematici, difficilmente poteva a quel tempo essere introdotto da qualcun altro".

${ }^{16} \mathrm{E}$, todavia, já Mondolfo, em sua nota, lembra-se da figura de Mamerco e de um possível centro de cultura matemática na Itália antes de Pitágoras (Zeller e Mondolfo 1938: 359).

${ }^{17}$ Ainda que a primeira formulação desta distinção tenha sido aquela de Boeckh, que distinguia entre a Sinnlichkeit jônica, cujo espelho seria o materialismo filosófico, e o Volk dórico, que remete para a busca da ordem (1819: 39-42). Não deve ser esquecido, além do mais, que Boeckh era discípulo de Schleiermacher, que por primeiro havia postulado este modelo de divisão étnica da filosofia em diversas tendências geopolíticas, e com modalidades evolucionistas, em suas aulas de 1812 publicadas postumamente sob o título de Etbik 1812/3 (Schleiermacher 1990).

${ }^{18}$ Orig.: "tanto più favorevole era il terreno che la filosofia trovò per sè nelle colonie della Magna Grecia. Il fiore al quale essa vi potè pervenire ne è la prova”. 
e restituída à dignidade filosófico-científica, seja também aquela que ele próprio prefere (Centrone 1999: 426). ${ }^{19}$

O privilégio concedido por Zeller à lectio aristotélica sobre os pitagóricos tornou-se, ao longo da história da crítica moderna, um trópos historiográfico predominante, contribuindo para definir a filosofia pitagórica sobretudo a partir da tese "tudo é número". ${ }^{20} \mathrm{Da}$ mesma forma, tanto a clara fratura entre o pitagorismo antigo e o neopitagorismo como o quase absoluto desprezo pela dimensão política da koinonía pitagórica influenciaram decididamente os estudos posteriores.

Exemplo da influência do ceticismo zelleriano são certamente as lições sobre os filósofos pré-platônicos que o amigo Nietzsche ministra em Basileia a partir do ano de 1872. É signifitiva a tese que Nietzsche defende em sua aula sobre Pitágoras:

Aquilo que se denomina filosofia pitagórica é algo de muito posterior, que é possível colocar somente na segunda metade do século V [a.C]. Portanto, ele não tem nenhuma relação com os filósofos mais antigos, pois não foi filósofo, mas algo diferente. A rigor, se poderia excluí-lo de uma história da filosofia mais antiga. Todavia, ele produziu um tipo de vida filosófica: e isso os gregos lhe devem. Esta imagem exerce uma notável influência, não sobre a filosofia, mas sobre os filósofos (Parmênides, Empédocles). Somente nestes termos deve-se falar dele (Nietzsche 1994: 39-40).

A própria possibilidade de falar de Pitágoras no interior da história da filosofia é colocada em sérias dúvidas, pois sua contribuição para ela é minimizada nos termos de uma influência sobre um genérico estilo de vida filosófico, privado de conteúdos. A posição de Nietzsche revela um ceticismo bastante radical, portanto. ${ }^{21}$

${ }^{19}$ Orig.: "Si ha l'impressione che, per felice coincidenza, l'immagine di Pitagora ricostruita da Zhmud, depurata il più possibile dalle componenti religiose e restituita a dignità filosoficoscientifica, sia anche quella che egli predilige".

${ }^{20}$ Ao menos até os estudos de Zhmud (1989: 272ss.; 1997: 261ss.), conforme será visto com mais detalhes, no capítulo quarto.

${ }^{21}$ Com a pergunta 'Pithagoras Philosophus?', Bechtle (2003) intitula, de forma inédita para um trabalho manualístico, seu capítulo sobre Pitágoras. 


\subsection{Diels: Uma Coleção “Zelleriana”}

Sobre a premissa aristotélico-zelleriana de que o pitagórico seria alguém que fala dos números, Diels organiza sua seleção de fragmentos e testemunhos nos Vorsokratiker (Diels 1903; Diels-Kranz 1951):

Foi exatamente este o critério que $H$. Diels usou para selecionar quem representaria a escola pitagórica em sua edição dos fragmentos dos présocráticos. A fonte primária (ainda que não única) foi o célebre catálogo dos pitagóricos encontrado em Jâmblico (VP: 267). Diels acreditava que este catálogo remontasse ao peripatético Aristóxeno (Zhmud 1989: 273).22

A anotação inicial ao capítulo XIV sobre Pitágoras não pode ser mais esclarecedora da dependência de Zeller:

Antes da época de Filolau não existia qualquer escrito de Pitágoras e havia somente uma tradição oral da escola mesma; por consequência não havia uma doxografia segura. [...] Cf. os testemunhos de Xenófanes, Heráclito, Empédocles, Íon sobre Pitágoras em correspondência dos próprios autores (Diels 1903: 22). ${ }^{23}$

A influência da coleção dielsiana para todos os estudos sobre o pitagorismo é indiscutível. ${ }^{24}$ De Vogel (1964: 9) mostra com razão que Diels recolhe da tradição mais tardia sobre Pitágoras e os pitagóricos somente o que diz respeito diretamente a Aristóxeno e suas Pythagorikai apophaseis (D), os Acusmata e Symbola (C), os testemunhos aristotélicos e de escola peripatética (B) e alguma pouca referência aos pitagoristas da Comédia ática intermediária (E). Com isso, exclui praticamente qualquer referência à atividade política de Pitágoras. Mesmo a revisão da coleção feita por Kranz para a sexta edição dessa obra (1951) mantém a impostação inicial de Diels: Kranz decide sim inserir, no capítulo sobre Pitágoras, o testemunho (14 A8a) sobre os discursos políticos de Pitágoras em Crotona de Porfírio (VP: 18-19). No entanto - anota De Vogel

${ }^{22}$ Orig.: "It was just this criterion which H. Diels used for selecting representatives of the Pythagorean school in his edition of the fragments of the presocratics. The main source (but not the only one) he had relied on was the well-known catalogue of Pythagoreans found in Iamblichus (Vit. Pyth. 267). Diels believed that this catalogue went back to the Peripatetic Aristoxenus".

${ }_{23}$ "Da es keine Schriften des Pythagoras gab und überhaupt vor Philolaos' Zeit nur mündliche Tradition der eigentlichen Schule bestand, so gibt es hier keine Doxographie. [...] Die Zeugnisse des Xenophanes [11 B7], Heraklit [12 B40.129(?)], Empedokles [21 B129], Ion [25 B4(?)] über P. s. bei diesen!”. Na VI Edição revista, Kranz (1951) qualificará como entscheidend wichtigen, importantes e decisivos, Die Zeugnisse dos outros presocráticos acima citados. Será preciso notar também que - contrariamente ao que afirma na nota introdutória acima citada - Diels acaba inserindo arbitrariamente, no fim, dois testemunhos doxográficos (A 20 e 21) sobre a descoberta da identidade entre os astros Espero e Lucífero e sobre o fato de ter

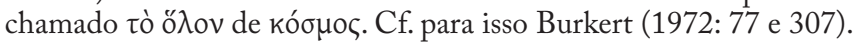

${ }^{24}$ Para uma resenha exaustiva do processo de elaboração da coleção, cf. Calogero (1941). 
- "é difícil que leve isso a sério" (1964: 9: "hardly took it seriously"), como demonstraria o fato que a respectiva redação dos discursos em Jâmblico (VP: 37-57), como os paralelos de Pompeu Trogo, continua não encontrando lugar na coleção. Os poucos testemunhos, nesse sentido, que Diels-Kranz coleta 14 A13 sobre matrimônio de Pitágoras, 14 A16 sobre a crise da comunidade pitagórica (Iambl. VP: 248-257) - são inseridos na seção Leben. Por outro lado, Kranz não muda nada no capítulo sobre a Pythagoreische Schule (58): o material aqui citado, que diria respeito diretamente a Pitágoras, é mantido com todos os cuidados bastante separado dele, a significar uma lectio que quer afastar os conteúdos deste material da autêntica filosofia pitagórica..$^{25}$

É mister lembrar que a arbitrariedade das escolhas de Diels-Kranz será objeto de todos os estudos que revisarão, ao longo do século XX, pontualmente, essa coleção. ${ }^{26}$

${ }^{25}$ Chama atenção, todavia, que em um artigo de 1890 Diels havia sugerido atribuir ao próprio Pitágoras alguns textos pitagóricos do período helenístico, entre eles especialmente o Kopides, um escrito retórico reconstruído a partir de uma referência em Heráclito, e o Paideutikón, Politikón, Physikón, na realidade escrito no século II a.C , em dialeto jônico, para parecer mais antigo que o dórico Perì Physios, de Filolau. Para os textos, veja-se agora a coleção de Thesleff (1965). De certa forma, portanto, ainda que inicialmente propenso a dar algum valor histórico à literatura pitagórica mais tardia, Diels parece mudar de ideia logo em seguida à publicação da obra de Zeller, em 1855.

${ }^{26}$ Philip (1966: 38) é categoricamente fatalista em afirmar que a parte dedicada ao pitagorismo é certamente a pior da coleção: "the fragments of Pythagoras and the Pythagoreans are, perhaps inevitably, the least satisfactory part of the Vorsokratiker". Não escapa da mordacidade de Philip nem sequer a coleção de Timpanaro Cardini (1958-1962): "Miss Cardini is as ready as Iamblichus to baptize as a Pythagorean anyone having the remotest connection with that 'brotherhood". 


\subsection{ROHDE: A REAÇÃO AO CETICISMO}

A primeira reação ao franco ceticismo de Zeller em relação às fontes pitagóricas não demora a aparecer: seu ponto de partida são certamente os dois artigos que Rohde publica, já na segunda metade do século XIX, na Rheinisches Museum, sobre as fontes da Vida Pitagórica, de Jâmblico (Rohde 1871; 1872). É exatamente nesse campo de trabalho da obra de Jâmblico que surgem os primeiros questionamentos relativos à pretensa verdade absoluta da equação entre fontes tardias e sua confiabilidade. Rohde mostra, com uma análise minuciosa, as dependências do texto de Jâmblico, não da vida paralela de Porfírio, como era opinião comum até então (Porphyrius, 1884: x), e, sim, de fontes neoplatônicas datadas dos séculos I e II EC, portanto, anteriores àquela: notadamente Nicômaco e Apolônio. Rohde procura fundamentar essa "teoria mecânica das duas fontes" (Burkert 1972: 100) partindo da ideia de que tanto Porfírio quanto Jâmblico escreveram seus textos em exercício nem sempre bem-sucedido do ponto de vista estilístico de corte e colagem. A confiança em sua teoria estende-se até o ponto de ironizar o "divino Jâmblico" por sua "pobreza mental e alma malemolente" (Rohde 1872: 60); em outro passo de seu segundo artigo (1872), volta a acusar Jâmblico por

Demonstrar significativa independência em nível tão vergonhoso, ao ponto de preparar uma mistura multicolorida arrumada a partir de recortes de suas leituras, enquanto a sequência desordenada e as improvisadas passagens conectivas seriam sua própria contribuição à obra (Rohde 1872: 48).27

Apesar de não resistir às sucessivas críticas que se queixavam da impiedosa arbitrariedade da compreensão do processo de confecção do trabalho de Jâmblico, de fato, o trabalho de Rohde abriu o caminho para uma longa Quellenforschung: as edições da Vida Pitagórica, de Jâmblico, de Bertermann (1913) e de Deubner (1937), dependem amplamente das pesquisas de Rohde, assim como os estudos de Corrsen (1912), Lévy (1926) e Frank (1923). ${ }^{28} \mathrm{Da}$ mesma forma, os comentadores que o acompanharam neste caminho puderam, em seguida, detectar no texto referências a autores do século IV a.C, como

${ }^{27}$ Orig.: "Hier zeigt Jamblich eine bei einem so elenden Stoppler schon bemerkenswerthe Selbständigkeit, indem er meist aus Brocken seiner Lektüre ein buntes Allerlei herstellt, an dem wenigstens die unruhige Unordnung der Reihenfolge und die das Einzelne nothdürftig verknüpfenden Betrachtungen sein eigenes Werk sind”.

${ }^{28}$ E significativo notar que somente quatro anos antes da publicação do primeiro artigo de Rohde, na mesma Rheinisches Museum für Philologie de 1868, Friedrich Nietzsche havia publicado um artigo (1868) dedicado ao mesmo tema das fontes das biografias tardias, desta vez em Diógenes Laércio. Nietzsche identifica, da mesma maneira que fará logo mais Rohde, em autores do I século aEC (Favorino e Díocles de Magnésia) as fontes das notícias biográficas esparsas na obra de Diógenes. O trabalho de Rohde, portanto, deve ser compreendido, ao lado daquele de ilustres colegas, como parte de amplo esforço de validação das fontes tardias por meio do estudo da "TraditionGeschichte" de suas obras. 
Aristóxeno, Dicearco, Heráclides Pôntico e Timeu. ${ }^{29}$ Entre eles certamente devemos considerar, in primis, Delatte, que, em seu trabalho sobre a literatura pitagórica, antes (1915), e sobre a Vida de Pitágoras, de Diógenes Laércio, depois (1922b), recolhe em amplo espectro cronológico e interdisciplinar as mais diferentes fontes desta obra, inspirado exatamente na metodologia de trabalho inaugurada por Rohde. $\mathrm{Na}$ mesma linha metodológica, situa-se o trabalho sobre a política pitagórica de Von Fritz (1940), que procura identificar material que possa ser referido a Aristóxeno, Timeu e Dicearco.

Assim, ao lado de Aristóteles, começam a aparecer, na literatura crítica moderna, nomes de autores quase tão antigos como referenciais para os estudos do pitagorismo em seu nascer. Deve-se notar, nesse sentido, que já os Doxographi Graeci, de Diels (1879), indicam Teofrasto como a fonte última do amplo material doxográfico reportado pela tradição: dessa forma, àquela que Diels chama de antiga tradição peripatética (58 B DK) será atribuído um papel central daqui para frente para a reconstrução do pitagorismo.

${ }^{29}$ Cf. Burkert 1972: 4. Para uma crítica da articulação dos argumentos de Rohde nos dois artigos citados, cf. Norden (1913) e depois Philip (1959). 


\subsection{BURNET: \\ O DUPLO ENSINAMENTO DOS ACUSMÁTICOS E MATEMÁTICOS}

Iniciador de uma brilhante tradição de scholars anglossaxões que se dedicaram aos estudos sobre as origens da filosofia antiga, Burnet, em sua obra Early Greek Philosophy (1908), é ainda devedor da lectio inaugural operada por Zeller: com efeito, desenvolve sua teoria tendo como pressuposto a clara separação entre a dimensão religiosa de Pitágoras e o desenvolvimento sucessivo do movimento, assim como certa distância entre as preocupações políticas e aquelas científicas das koinoníai pitagóricas. Com base nesse denominador comum, Burnet elabora uma lectio própria que não desdenha as recentes posições menos céticas, como aquela de Rohde (Burnet 1908: 91 n1), inaugurando uma linha interpretativa baseada na célebre distinção no interior do movimento pitagórico, entre os acusmáticos e os matemáticos. Distinção esta que se tornará tradicional na história da crítica e distingue, de um lado, o interesse por parte de alguns nos tabus tradicionais de uma religiosidade arcaica (os akoúsmata e sýmbola) e, do outro, a franca dedicação à pesquisa de princípios científicos, notadamente matemáticos. Distinção, enfim, já presente nas fontes relacionadas à menção à didaskalía dítton, ao duplo ensinamento de Pitágoras em Porfírio e à distinção entre os Pitagoreus e os Pitagoristas (estes últimos imitadores dos primeiros, e que corresponderiam aos acusmáticos) em Jâmblico (Porph. VP: 37, Iambl. VP: 80). ${ }^{30}$ É preciso notar que, apesar de os usos sucessivos dessa distinção inicial tenderem a sublinhar o gap entre os dois grupos, a bem ver, essa mesma distinção não pressupõe, nas intenções iniciais de Burnet - assim como nas Vidas anteriormente citadas -, alguma separação definitiva entre dois lados no interior do mesmo pitagorismo das origens. Ao contrário, o mesmo Burnet identifica em dois lugares pontos de contato: a) na complexa figura do próprio Pitágoras, que estaria na origem de ambas as didaskaliai (Burnet 1908: 107); b) no conceito de kathársis, de purificação, que conecta o aspecto religioso e aquele científico, uma vez que ciência também se torna, ela própria, um instrumento de purificação:

Precisamos considerar que há aqui um reavivamento da filosofia religiosa, principalmente porque se sugere a ideia de que a filosofia seja acima de tudo um "estilo de vida". Mesmo a ciência era uma purificação, uma maneira de fugir da "roda" [da geração]. Esta é a visão expressada tão fortemente no Fédon de Platão, o qual foi escrito sob a influência das doutrinas pitagóricas (Burnet 1908: 89). ${ }^{31}$

Assim, não é possível concordar com a acusação um tanto sumária de De

${ }^{30}$ Cf. para uma discussão sobre as fontes da distinção entre acusmáticos e matemáticos a seção 1.2, a seguir.

${ }^{31}$ Orig.: "We have to take account of the religious Philosophy as revival here, chiefly because it suggested the view that a philosophy was above all a 'way of life'. Science too was a 'purification', a means of escape from the 'wheel'. This is the view expressed so strongly in Plato's Phaedo, which was written under the influence of Pythagorean ideas". 
Vogel, pela qual "Burnet não presta atenção para o caráter ético-religioso do bios fundado por Pitágoras e para a conexão essencial deste aspecto com os assim chamados princípios científicos" (1964: 11)..$^{32}$ Ao contrário, é exatamente pelo conceito de purificação que essa conexão é afirmada e compreendida em sua profundidade teórica, para além da realidade histórica concreta do movimento. ${ }^{33}$

Contudo, é certamente merecedora de críticas, em Burnet, uma abordagem formalmente apriorística da questão das fontes: por ela, tudo o que é arcaico seria religioso, enquanto tudo o que é mais recente seria científico. Assim, o pitagorismo das origens estaria ligado a modos de pensamento primitivos, facilmente detectáveis na tradição dos akoúsmata e sýmbola:

Seria fácil multiplicar as provas de uma conexão próxima entre o pitagorismo e os modos de pensamento primitivos, mas o que foi dito é já suficiente para nosso propósito. $\mathrm{O}$ parentesco de homens e animais, a abstinência da carne e a doutrina da transmigração estão todas juntas e formam um conjunto perfeitamente inteligível (Burnet 1908: 106). ${ }^{34}$

O divisor de águas da questão das fontes torna-se, em Burnet, o matemático Aristóxeno, que inaugura esta distinção entre o grupo mais iluminado da escola e a parte supersticiosa e - daqui para frente - herética do pitagorismo. Nas palavras do próprio Burnet:

À época deles, a parte simplesmente supersticiosa do pitagorismo foi abandonada, com a exceção de alguns zelotas que a direção da Sociedade recusava-se a reconhecer. Eis porque ele apresenta o próprio Pitagóras em luz tão diferente seja das tradições mais antigas como das mais recentes; é porque ele nos concedeu o ponto de vista da seita mais iluminada da Ordem. Aqueles que colaram fielmente às velhas práticas eram agora considerados heréticos, e todo tipo de teorias era colocado na situação de ter de dar razão de sua existência (Burnet 1908: 106)..$^{35}$

A maior purificação é a ciência desinteressada (disinterested science), e, portanto, o ser humano que a ela se dedicar devotamente, isto é, o filósofo, poderá se livrar do ciclo da geração (1908: 107). Contudo, não foge obviamente a

32 Orig.: "Burnet had no eye for the ethico-religious character of the ßíos founded by Pythagoras and for the essencial connection of this aspect with the so-called scientific principles".

${ }_{33}$ Burnet cita (1908: 98 n3) e desenvolve aqui a intuição sobre a unidade entre ciência e

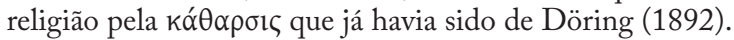

${ }^{34}$ Orig.: "It would be easy to multiply proofs of the close connexion between Pythagoreanism and primitive modes of thought, but what has been said is really sufficient for our purpose. The kinship of men and beasts, the abstinence from flesh, and the doctrine of transmigration all hang together and form a perfectly intelligible whole".

${ }_{35}$ Orig.: "in their time, the merely superstitious part of Pythagoreanism had been dropped, except by some zealots whom the heads of the Society refused to acknowledge. That is why he represents Pythagoras himself in so different a light from both the older and the later traditions; it is because he gives us the view of the more enlightened sect of the Order. Those who clung faithfully to the old practices were now regarded as heretics, and all manner of theories were set on foot to account for their existence". 
Burnet que a grande questão é quanto dessa visão pós-aristoxênica é atribuível ao próprio Pitágoras:

Seria imprudente afirmar que Pitágoras havia se expressado exatamente desta maneira; mas todas essas ideias são genuinamente pitagóricas, e é somente dessa forma que podemos cobrir a distância que separa Pitágoras, o homem da ciência, do Pitágoras, o mestre religioso (1908: 107-108). ${ }^{36}$

A ponte que pretende separar os dois Pitágoras, o homem da ciência e o mestre religioso, é o problema central que acompanha, daqui para frente, a história da crítica do espinhoso problema da complexidade multifacetada do pitagorismo.

Ao mesmo tempo em que Burnet declara a necessidade de superá-la, para encontrar em Pitágoras a origem das duas vertentes, está de fato pressupondo a existência delas: pois que haja uma distância a ser superada entre pensamento científico e pensamento religioso, tanto na antiguidade quanto hoje, é esta mesma uma afirmação a ser provada e, certamente, é um preconceito hermenêutico, tanto amplamente em uso quanto indemonstrado.

Assim, em conclusão ao seu capítulo dedicado ao pitagorismo, Burnet reconhece ter elaborado sua reconstrução da figura de Pitágoras "simplesmente atribuindo a ele aquelas porções do sistema pitagórico que parecem ser as mais antigas" (1908: 123). ${ }^{37}$ Todavia, a definição do que é o mais antigo corresponde à quase totalidade do problema a ser enfrentado, e não pode ser resolvida sucintamente com uma cronografia positivista, como Burnet parece querer.

Ainda assim,é o caso de voltar a anotar aqui: o esforço de Burnet para manter juntas as diversas tradições sobre Pitágoras é fundamental para compreender as sucessivas intervenções hermenêuticas sobre a literatura pitagórica, que, de Cornford a Guthrie, desenham lentamente o caminho da composição da diversidade de tradições em que tanto a figura de Pitágoras quanto o imediato desenvolvimento do movimento encontram-se mergulhados.

${ }^{36}$ Orig.: "It would be rash to say that Pythagoras expressed himself exactly in this manner; but all these ideas are genuinely Pythagorean, and it is only in some such way that we can bridge the gulf which separates Pythagoras the man of science from Pythagoras the religious teacher".

37 Orig.: "simply assigned to him those portions of the Pythagorean system which appear to be the oldest". 


\subsection{Cornford e Guthrie: EM BUSCA DA UNIDADE ENTRE CIÊNCIA E RELIGIÃO}

Em um artigo, publicado em duas partes sucessivas, na Classical Quarterly (em 1922 e 1923), intitulado significativamente Mysticism and Science in the Pythagorean Tradition, Cornford aborda a questão, de certa forma deixada em aberto por Burnet, da correta abordagem das relações entre religiosidade e interesses científicos no pitagorismo, evitando reducionismos e anacronismos de matriz positivista que este último aparentemente não teria conseguido evitar. Os dois artigos seguem de perto a já consolidada perspectiva historiográfica do autor inglês: em sua obra inaugural sobre as complexas relações entre mito e história em Tucídides, Thucydides Mythistoricus (1907), o objetivo é o de afastar-se das tendências da história moderna, que seria vítima da típica "falácia modernista”, por projetar na obra do historiador ateniense noções de cientificidade derivadas em seus fundamentos da biologia darwiniana e da física contemporânea. ${ }^{38}$

Sobre esse pano de fundo teórico, Cornford enfrenta a vexata quaestio da presença, nos séculos VI e V a.C, de dois "sistemas de pensamento diferentes e radicalmente opostos elaborados no interior da escola pitagórica. Eles podem ser chamados respectivamente de sistema místico e sistema científico" (Cornford 1922: 137)..$^{39}$ Enquanto todas as tentativas hermenêuticas a ele contemporâneas procuram articular os dois sistemas em uma imagem coerente do movimento, Cornford reconhece haver certa confusão entre os dois sistemas. Essa confusão é já perceptível nas obras de Aristóteles e precisará ser desvendada. A solução proposta por Cornford é a de distinguir, no interior do pitagorismo, dois momentos históricos diferentes e sucessivos, cujo divisor de águas - no começo do século $\mathrm{V}$ a.C - seria a polêmica eleática contra a derivação da multiplicidade da realidade de uma única arché. Cornford resume da seguinte forma a imagem do pitagorismo que resulta dividido por essa polêmica:

Podemos, em uma palavra, distinguir entre (1) o sistema original de Pitágoras, datado no século VI [a.C], criticado por Parmênides - o sistema místico e (2) o pluralismo datado no século $V$, construído para confrontar as objeções de Parmênides, e por sua vez criticado por Zenão - o sistema científico, que pode ser chamado de "atomismo numérico" (Cornford 1922: 137). ${ }^{40}$

Essa divisão entre misticismo e ciência no pitagorismo encontra-se apenas aparentemente em continuidade com a separação entre religião e

38 Para uma análise mais ampla desta obra, assim como da posição historiográfica de Cornford, cf. Murari (2002).

39 Orig.: "different and radically opposed systems of thought elaborated within the Pythagorean school. They may be called respectively the mystical system and the scientific".

${ }_{40}$ Orig.: "We can, in a word, distinguish between (1) the original sixth-century system of Pythagoras, criticized by Parmenides - the mystical system, and (2) the fifth-century pluralism constructed to meet Parmenides' objections, and criticized in turn by Zeno - the scientific system, which may be called 'Number-atomism”'. 
ciência proposta por Burnet. De fato, imediatamente após indicar a separação acima descrita, Cornford anota que há um terceiro momento do pitagorismo, aquele de Filolau, que também pertence à margem mística, mas que se coloca cronologicamente mais tarde:

Há também (3) o sistema de Filolau, que pertence ao lado místico da tradição, e procura acomodar a teoria empedocleia dos elementos. Este, para nossos atuais propósitos, pode ser deixado de lado (Cornford 1922: 137). ${ }^{41}$

O ponto mais significativo aqui é a sutil mudança de perspectiva - no interior da história da crítica - que esta divisão de Cornford representa: colocando a ênfase da distinção entre as duas margens do pitagorismo no debate histórico com o eleatismo, retira-se o apriorismo - acima citado - que postula uma anterioridade da religiosidade à ciência. Com efeito, ao descrever o lado místico do movimento, Cornford afirma britanicamente - é mesmo o caso de dizer - sua "não evidente inconsistência" com a filosofia:

Toda tentativa de resgatar o sistema original do fundador deverá, eu diria necessariamente, basear-se no pressuposto pelo qual sua filosofia e cosmologia não estariam evidentemente inconsistentes com sua religião (Cornford 1922: 138). ${ }^{42}$

Com um argumento francamente antievolucionista, Cornford afirma, portanto, que, diferentemente da primeira fase jônica da filosofia em suas origens, em que o elemento religioso havia sido deixado de lado, nesse segundo momento itálico recupera-se a dimensão religiosa da vida filosófica:

É óbvio que a tradição filosófica itálica difere radicalmente daquela jônica com respeito à sua relação com a crença religiosa. Diferentemente dos Jônicos, ela começa não pela eliminação dos fatores que uma vez possuíam significado religioso, mas ao contrário com uma reconstrução da vida religiosa. Para Pitágoras, conforme é geralmente admitido, o amor pela sabedoria, a filosofia, era um estilo de vida. Pitágoras foi tanto um grande reformador religioso, o profeta de uma sociedade congregada pela reverência à sua memória e pela observância de uma regra monástica, e também um homem de excepcionais poderes intelectuais, em destaque entre os fundadores da ciência matemática (Cornford 1922: 138-139). ${ }^{43}$

41 Orig.: "There is also (3) the system of Philolaus, which belongs to the mystical side of the tradition, and seeks to accommodate the Empedoclean theory of elements. This may, for our present purpose, be neglected".

42 Orig.: "Any attempt to reconstruct the original system of the founder must, I would urge, be based on the presupposition that his philosophy and cosmology were not openly inconsistent with his religion".

43 Orig.: "It is obvious that the Italian tradition in philosophy differs radically from the Ionian in respect of its relation to religious belief. Unlike the Ionian, it begins, not with the elimination of factors that had once had a religious significance, but actually with a re-construction of the religious life. To Pythagoras, as all admit, the love of wisdom, philosophy, was a way of life. 
Assim, a figura de Pitágoras poderá ser ao mesmo tempo compreendida como a de um reformador religioso e de um homem de ciência. A distinção final dessas duas margens acontecerá só em seguida, em ocasião da polêmica eleata, notadamente zenoniana; ainda que não de forma tão definida, se for considerada a terceira margem filolaica por ele próprio indicada (ainda que não discutida).

Raven (1948) bem compreendeu a novidade da posição de Cornford, ao afirmar em seu Pythagoreans and Eleatics: "uma das razões pelas quais a reconstrução de Cornford do pitagorismo mais antiga é tão atrativa é que ela imagina poder reconciliar o motivo religioso com aquele científico" (Raven 1948: 9).44

Seguindo de perto os argumentos de Cornford e a imagem coerente e plausível que deles resulta, Raven, todavia, propõe-se à precisa tarefa de verificar se as conclusões às quais Cornford chega seriam de fato as únicas possíveis. Pois a questão não é tanto - segundo Raven - aquela de ter uma visão coerente do movimento, e, sim, o quanto esta "condiz com todas as nossas evidências disponíveis"('tallies with all our avaliable evidence'), a começar pelos testemunhos aristotélicos, sem os quais qualquer tentativa de construção de um discurso histórico sobre o pitagorismo é, em seu dizer, "uma casa construída sobre areia" ("a house built upon sand" - Raven 1948: 6).45

É exatamente essa a leitura que propõe Guthrie (1962), provavelmente o último grande comentador pertencente à tradição de intérpretes ingleses que tem suas origens em Burnet. Não por acaso, Guthrie refere-se diretamente aos estudos citados de Cornford (1922; 1923) e, depois, aos de seu discípulo Raven (1948), para exemplificar aquele que chama de método "a priori" da história da filosofia pré-socrática. O método consiste fundamentalmente em deixar de lado, por um instante, os testemunhos diretos ou indiretos e procurar imaginar aquilo que os referidos filósofos teriam provavelmente ('likely') dito ou não, dadas as circunstâncias históricas em que se achavam. Guthrie comenta assim os pressupostos teóricos do método:

[Esse método] parte do pressuposto de que possuímos certa familiaridade geral com outras escolas contemporâneas e filósofos individuais e com o ambiente de pensamento no qual os pitagóricos trabalharam. Este conhecimento geral da evolução da filosofia grega dá a alguém - é o que aqui se reivindica - o direito de fazer julgamentos pelos quais os pitagóricos, vamos dizer, antes de

Pythagoras was both a great religious reformer, the prophet of a society united by reverence for his memory and the observance of a monastic rule, and also a man of commanding intellectual powers, eminent among the founders of mathematical science".

${ }^{44}$ Orig.: "One of the reasons why Cornford's reconstruction of early Pythagoreanism is so attractive is that is contrives to reconcile the religious with the scientific motive".

45 É certamente o caso de sublinhar que Cherniss (1977), apoiando o esforço de Raven, chega a diminuir polemicamente o impacto da divisão proposta por Cornford sobre os estudiosos "fora de Cambridge": "Raven was justified in feeling that the evidence does not support Cornford's interpretation, which incidentally has never been so widely accepted outside of Cambridge as he appears to believe" (1977: 376). 
Parmênides, devem provavelmente ter sustentado a doutrina A, e é impossível que tenham, naquele estágio do pensamento em que se encontravam, já terem desenvolvido doutrina B (Guthrie 1962: 172). ${ }^{46}$

Esses pressupostos levam, assim, a postular a existência de duas correntes da filosofia em seu nascer: a jônica e a itálica. ${ }^{47}$ Todos os autores, de certa forma, serão assim posicionados teoreticamente de um ou outro lado. $\mathrm{O}$ apriorismo do método é evidente: talvez por isso, ainda que simpatizando por ele, Guthrie sugere a "máxima cautela possível em seu uso"(1962: 172).E, com esta admoestação, encerra-se a preocupação metodológica tendente a controlar o evidente risco de circularidade das conclusões..$^{48}$

Nessa linha metodológica,com a intenção declarada de querer compreender o pitagorismo pré-platônico, sob pena de, caso contrário, não entender Platão, Guthrie afirma em geral a unidade do primeiro:

Este pitagorismo pré-platônico pode ser considerado em larga parte como uma unidade. Poderemos verificar desenvolvimentos e diferenças como e quando quisermos, mas seria pouco sábio esperar que estes, diante do estado fragmentário de nosso conhecimento, sejam suficientemente distinguíveis ao ponto de permitir um tratamento separado entre fases mais recentes e outras mais tardias (1962: 147). ${ }^{49}$

Novamente, como no caso de Cornford, a distinção deverá ser definida, no interior do pitagorismo pré-platônico, exclusivamente em termos cronológicos. Porém, dessa forma, a unidade teórico-doutrinária do movimento, ao menos no interior de suas diferentes fases históricas, é garantida.

Ao mesmo tempo em que, provavelmente influenciados pelos esforços da escrita das grandes Histórias da Filosofia do século XX, os estudiosos

${ }^{46}$ Orig.: "It starts from the assumption that we possess a certain general familiarity with other contemporary schools and individual philosophers, and with the climate of thought in which the Pythagoreans worked. This general knowledge of the evolution of Greek philosophy gives one, it is claimed, the right to make judgments of the sort that the Pythagoreans, let us say, before the time of Parmenides are likely to have held doctrine A, and that it is impossible for them at that stage of thought to have already evolved doctrine B".

${ }^{47}$ É mesmo o caso de notar que essa divisão remonta já à clássica divisão entre filosofia

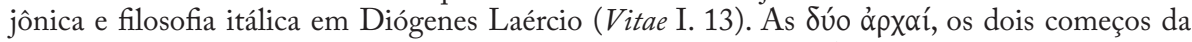
filosofia, são identificados por Diógenes Laércio, de um lado em Anaximandro para a vertente jônica, da qual farão parte Anaxímenes, Anaxágoras, Arquelau e, enfim, Sócrates; do outro lado, em Pitágoras, inventor do termo $\varphi \imath \lambda o \sigma o \varphi i ́ \alpha$, para a outra vertente, aquela itálica, sendo este seguido pelo filho Telauge, depois Xenófanes, Parmênides, Zenão, Leucipo, Demócrito até Epicuro (D. L. Vitae I. 13-14). Para uma discussão historiográfica mais aprofundada dos modelos historiográficos das origens da filosofia antiga, cf. Sassi (1994).

${ }^{48}$ Para uma crítica veemente a este apriorismo metodológico no interior dos estudos sobre o pitagorismo, cf. Kahn (1974: 163 n6).

${ }^{49}$ Orig.: "This pre-Platonic Pythagoreanism can to a large extent be regarded as a unity. We shall note developments and differences as and when we can, but it would be unwise to hope that these, in the fragmentary state of our knowledge, are sufficiently distinguishable chronologically to allow the separate treatment of earlier and later phases". 
preocupavam-se em compreender essa mesma unidade e, portanto, procurar dar conta da filosofia pitagórica como um todo; começaram a surgir, no panorama da crítica, obras dedicadas ao estudo de algumas áreas particulares e alguns problemas específicos da Quellenforschung do pitagorismo: é o caso certamente dos estudos sobre a política, das relações entre pitagorismo e Platão e da compreensão das relações entre o pitagorismo e o mundo religioso em sua volta. Infelizmente - é mesmo o caso de dizer -, após a Segunda Guerra, os dois tipos de literatura dificilmente voltarão a dialogar entre si: os manuais de História da Filosofia continuarão seguindo, em sua grande maioria, a impostação zelleriana, enquanto os estudos monográficos sobre o pitagorismo revelarão complexidades até hoje - de maneira geral - desconhecidas aos primeiros. 


\subsection{De Delatte a De Vogel: pitagorismo e política}

Uma especial atenção na história da crítica foi dedicada à dimensão política do pitagorismo, desde que, em 1830, a monografia de Krische afirmou, peremptoriamente, o caráter eminentemente político da societas pitagórica: "o escopo da Sociedade foi meramente político, não somente para restituir inicialmente o poder decaído dos aristocratas, mas para consolidá-lo e amplificá-lo" (Krische 1830: 101).50

Estudos arqueológicos das evidências numismáticas já revelavam, no começo do século XX, uma dominação das cidades pitagóricas sobre todo o território da Magna Grécia, o que foi comprovado pelos estudos de Kahrstedt sobre as moedas cunhadas por Crotona e espalhadas por todo o território, especialmente após a derrota de Síbaris em 510 a.C (Kahrstedt 1918, 186). ${ }^{51}$ A dominação de Crotona sobre o restante das cidades-colônias dóricas da Magna Grécia confirmaria as notícias da influência política pitagórica: de fato, grande parte dessas moedas apresenta símbolos pitagóricos..$^{52}$

E, todavia, conforme já foi dito, as primeiras abordagens historiográficofilosóficas à política pitagórica dependem fortemente da influência do ceticismo de Zeller, que, por sua vez, orientou a coleção de Diels dos Vorsokratiker: ambos concorriam para levar a maioria dos comentadores a considerar o tema da política pitagórica como simplesmente acidental (Centrone 1996: 196).

É mister concordar com a opinião de que a relação entre pensamento filosófico e prática política (reformista ou menos) na história do pitagorismo desafiou a ingenuidade dos classicistas (D. S. M. 1943: 79): ingenuidade esta que tenderia - se deixada à sua sorte - a rejeitar as conexões políticas com base no argumento apriorístico pela qual um homem como Pitágoras não poderia estar envolvido nesse tipo de atividade (Minar 1942: 15).

Portanto, o problema do envolvimento político dos pitagóricos apresenta um quadro de questôes multifacetado: não somente por causa das relações imbricadas entre fontes antigas e mais recentes, pela incerta cronologia da dominação (e da derrota) dos pitagóricos na Magna Grécia e pela pouco clara influência de Pitágoras sobre sua forma; mas também, quiçá principalmente, pela dificuldade teórica dos comentadores em articularem uma relação entre filosofia e política que, já a partir de Aristóteles, começa a ser vista como um tanto inapropriada.

Nesse sulco hermenêutico insere-se certamente a obra fundamental de Delatte (1922a), Essai sur la politique pythagoricienne. Este, ao mesmo tempo

${ }^{50}$ Orig.: Societatis scopus fuit mere politicus, ut lapsam optimatum potestatem non modo in pristinum restitueret, sed firmaret amplificaretque.

${ }^{51}$ Cf. também Seltman (1933), De Vogel (1957: 323) e May (1966).

${ }^{52}$ Cf. as moedas em Seltman (1933: 76-80, 100, 118, 144) e May (1966: 157, 167). De maneira especial, a moeda n. 28 (Seltman 1933: 144), representando um homem barbado com a inscrição PUTHAGORES, poderia ser um retrato do próprio Pitágoras, e como tal já foi utilizada por Guthrie para a capa do primeiro volume de sua History of Greek Philosophy (1962). Philip (1966: 194) é, todavia, cético com a possibilidade de a imagem representar o semblante real de Pitágoras. 
em que realiza um exaustivo estudo das fontes para a política pitagórica, que o leva a confiar na plausibilidade de efetiva ação política protopitagórica em Crotona, remete para um período sucessivo, notadamente para o século IV aEC, século de Arquitas e dos testemunhos de Aristóxeno, a imbricação dessa atividade com as linhas fundamentais do pensamento filosófico: até lá, sustenta Delatte, as primeiras koinoníai pitagóricas procuravam, mais diretamente, a "paz interior", abstendo-se de uma ação reformista ou mais em geral muito envolvida nas instituições políticas de suas cidades: "a Sociedade deseja somente a paz interior, que lhe assegure sua própria tranquilidade e mantenha as instituições existentes, das quais ela se tornara mantenedora"(Delatte 1922a: 21)..$^{53}$

Ademais, se é verdade que a comunidade pitagórica está de certa forma envolvida na atividade política, não é necessariamente o caso de pensar que o próprio Pitágoras estivesse envolvido diretamente com isso:

Alguém poderia concluir que a política de tendências aristocráticas que, segundo Timeu, marca o fim da história da Sociedade, não seja um impulso de Pitágoras, como também que a política seja, ao que parece, estranha ao seu plano de reformas (Delatte 1922a: 18). ${ }^{54}$

Por consequência, Delatte explica o fato central das revoltas democráticas antipitagóricas como o resultado não tanto do compromisso político da comunidade como tal em sentido aristocrático e conservador (pelo contrário, considerada mais apropriadamente como uma força moral), mas, sim, das atitudes de alguns indivíduos que se utilizavam de seu prestígio e que acabaram arrastando-a para o conflito em movimento reativo aos ataques que se seguiram, e, portanto, na forma de autodefesa (1922a: 19-20).

Jaeger (1928), por sua vez, sustenta a tese, em verdade originalmente zelleriana, de que o que diz respeito à política pitagórica resume-se em uma projeção do ideal tardio da vida prática por parte de autores como Aristóxeno e Dicearco: o Pitágoras de Jaeger, na mesma linha de Delatte, seria mais um educador, mestre de uma educação baseada na música e na matemática.

Em seguida, Von Fritz (1940) pergunta-se se de fato é possível afirmar que a comunidade pitagórica antiga controlasse politicamente, e de forma direta, o poder das cidades da Magna Grécia. Por meio de uma "austera investigação das fontes" (Tate 1942: 74), identifica em Aristóxeno a testemunha mais confiável para uma reconstrução da trajetória política das comunidades pitagóricas, e conclui ceticamente que:

${ }^{53}$ Orig.: "la Société désire seulement la paix intérieure, qui lui assure sa propre tranquillité, et le mantien des instituitions existantes, dont elle est devenue maîtresse".

${ }^{54}$ Orig.: "On peut done conlure que la politique à tendances aristocratiques qui, selon Timée, caractérise la fin de l'historie de la Société, n' est pas née d'une impulsion de Pythagore, et même que la politique était, selon toute vraisemblance, étrangère à son plan de reformes". 
As tradições antigas não fornecem a menor evidência da existência de algo que possa ser considerado como um poder real dos pitagóricos em nenhuma cidade da Itália Meridional em qualquer época (Von Fritz 1940: 95 ).55

A posição de Von Fritz, portanto, não difere substancialmente, em última análise, daquela de seus predecessores: o compromisso político dos pitagóricos é algo que deve ser atribuído mais diretamente a escolhas pessoais, por vezes motivadas religiosamente, de alguns membros isolados da koinonía, e não a uma ação filosófica do grupo como tal.

É somente Minar (1942), em sua obra dedicada à política pitagórica originária, que primeiramente revela estar consciente de todos os perigos e as precompreensões historiográficas inerentes ao tratamento da questão política do pitagorismo. No prefácio dessa obra, declara imediatamente querer enfrentar aquele que considera o paradoxo representado por uma escola filosófica envolvida em atividades políticas:

Que a sociedade pitagórica tenha exercido uma influência política nas cidades do Sul da Itália nos séculos sexto e quinto antes de Cristo tem sido um fato reconhecido. Contudo, o paradoxo de uma escola filosófica envolvida na atividade política trouxe muita dificuldade para o juízo histórico sobre os fatos $(1942: v) .^{56}$

Minar não esconde o fato de vários autores antigos afirmarem explicitamente que os pitagóricos (e mesmo Pitágoras) teriam exercitado formalmente o controle do governo em Crotona e em outras cidades (Minar 1942: 16): Diógenes Laércio, Porfírio, Jâmblico, Cícero, entre outros. ${ }^{57}$ Desse modo, opõe-se ao argumento, recorrente entre seus predecessores, de que a atividade política era uma opção isolada de alguns membros, por um lado o caráter fortemente centralista da comunidade, por outro o fato histórico de a revolta ser dirigida contra a comunidade como um todo. Ambas as tradições indicariam como pouco provável que a opção política se limitasse a uma atividade marginal de alguns poucos membros:

O caráter altamente centralizado da Sociedade, conforme admite Von Fritz, torna improvável que a atividade política pitagórica reduza-se simplesmente àquela de membros individuais; e o fato de que a revolta contra o governo no poder era a mesma coisa que um ataque contra a Sociedade, ou, ao menos que um ataque deste gênero a envolveria de forma integral, sugere fortemente que a

55 Orig.: "Ancient tradition does not provide the slightest evidence for the existence of anything like a real rule of the Pythagoreans in any of the cities of Southern Italy at any time".

56 Orig.: "That the Pythagorean Society exercised a political influence in the cities of southern Italy in the sixth and the fifth centuries B.C. has long been a recognized fact. But the paradox of a philosophical school being involved in political activity has brought a certain amount of difficulty into the historical evaluation of the facts".

${ }^{57}$ D. L. Vitae VIII. 3; Porph. VP: 20, 21, 54; Iambl VP: 30, 130, 249, 254; Cicero. Tuscul. 5.4.10. 
Sociedade pitagórica era reconhecida como o verdadeiro governo em Crotona e na maioria das cidades da Magna Grécia (Minar 1942: 18)..$^{58}$

O pitagorismo constituiria, assim, o verdadeiro poder dominante em diversas cidades da Magna Grécia. Caberá depois aos historiadores modernos, em geral pouco acostumados a essa estreita relação entre filosofia e política, compreender a imbricação das duas dimensões - que Minar define como teórica e prática - do pitagorismo em uma unidade dinâmica.

A parte menos convincente da leitura de Minar é provavelmente aquela que tenta articular essas duas partes entre si, fundamentalmente por acabar dando à componente doutrinária da filosofia política pitagórica um peso muito inferior ao que se esperaria (Minar 1942: 95-132), reduzindo Pitágoras e seu movimento a uma sociedade política marcada por certo oportunismo e pragmatismo..$^{59}$

Não é obviamente por mero acaso que diversos estudiosos italianos interessaram-se pelo pitagorismo e, de maneira especial, por sua dimensão política: sem chegar aos extremos chauvinistas de Capparelli (1941), diversos autores, a começar por Rostagni (1922) e pela revisão da obra de Zeller feita por Mondolfo (1938), procuraram articular as duas dimensões (mística e científica) em um complexo conjunto historiográfico em que a dimensão política ocupa um papel central. $O$ sentido dessa tradição pode ser compreendido com precisão pela definição que abre a obra clássica de Ferrero, Storia del Pitagorismo nel mondo romano:

O pitagorismo, à prova dos fatos, demonstrou-se algo maior e diferente de um abstrato fenômeno de cultura, da manifestação de um especial endereço religioso-dogmático, ou, enfim, de mera expressão intelectualística. Esse foi, se não estamos errados, notadamente a expressão de um fato social e político conectado a uma estrutura permanente do mundo antigo; foi a expressão característica de uma organização dos intelectuais que respondia às exigências de um grupo dominante, de uma eleita política, a qual em um primeiro momento, como as teocracias, identificou-se e foi uma só realidade com os mesmos intelectuais (Ferrero 1955: 21). ${ }^{60}$

${ }^{58}$ Orig.: "The highly centralized character of the Society, which von Fritz recognizes, makes it unlikely that Pythagorean political activity was merely that of individual members; and the fact that a revolt against the government in power was the same thing as an attack against the Society, or at least involved such an attack as an integral part, strongly suggests that the Pythagorean Society was recognized as the real ruler in Croton and most of the cities of Magna Graecia”.

${ }^{59}$ Deve-se concordar aqui com De Vogel (1966: 13), quando sugere que Minar concluiria que "Pythagoras was rather a shrewd politician, an aristocratic reactionary at a time of rising democracy - and that all this had nothing to do with philosophy”. Minar (1942: 99) parece creditar à doutrina política dos pitagóricos a simples função de uma superestrutura, afirmando que "the relationship between practice and theory will be seen most clearly through an analysis of the doctrinal superstructure which this group built up about its political activity".

${ }^{60}$ Orig.: "Il pitagorismo alla prova dei fatti si dimostró qualcosa di più e di diverso di un astratto fenomeno di cultura, della manifestazione di un particolare indirizzo religiosodogmatico, o infine di una mera espressione intellettualisica. Esso fu, se non andiamo errati, 
A apropriação italiana do pitagorismo tem suas origens já em época romana. Um breve excursus sobre essa tradição pode mostrar claramente a profundidade da identificação étnico-política do pitagorismo com a cultura itálica.

Baseando-se na ambiguidade inerente ao termo "filosofia itálica", e utilizando-se de uma variação das lendas sobre Pitágoras pela qual seria este filho de um tirreno, isto é, de um etrusco, Pitágoras é considerado como um dos antepassados da cultura política, filosófica e religiosa de Roma. ${ }^{61} \mathrm{O}$ filósofo sâmio acaba, assim, por ser inscrito nas listas dos cidadãos romanos (Plinio, Hist. Nat. XXXIV 26) e acreditado como mestre do rei-sacerdote Numa Pompílio (Plutarco, Numa 8). Significativamente, Cicero, ao mesmo tempo em que quer dissipar o erro do patente anacronismo desse discipulado de Numa, acaba confirmando a tradição patriótica da qual este deriva:

Considero que por admiração aos pitagóricos até o rei Numa foi identificado pelos posteriores como pitagórico. Estes de fato conheciam a teoria e as regras de Pitágoras, e de seus antepassados haviam recebido a notícia da equidade e sabedoria daquele rei; mas ignorando a idade daqueles homens e as épocas, por causa da distância temporal, acreditaram que este, que se destacava por sabedoria, fosse discípulo de Pitágoras (Cicero. Tusc. Disp. IV: $1-2) \cdot{ }^{62}$

Em diversos passos ciceronianos, os pitagóricos, definidos como "quase nossos concidadãos, eles que eram então chamados de filósofos itálicos” (Cato Maior XXI: 78), tornam-se um capítulo central da gloriosa história romana (Tusc. Disput. IV). ${ }^{63}$ Uma famosa passagem das Metamorfoses, de Ovídio (XV: 1-447), assim como outra da Vida de Numa, de Plutarco (I: 8 e 11), reafirmam a conexão entre Numa e Pitágoras, consolidando, dessa forma, a tradição anterior da romanidade e da italianidade de Pitágoras. ${ }^{64}$

A própria literatura filosófico-teológica da Idade Média, apesar de não ter tido acesso às Vidas de Diógenes Laércio, Porfírio e Jâmblico, assim como a

specialmente l'espressione di un fatto sociale e politico collegato ad una struttura permanente del mondo antico; fu l' espressione caratteristica di un' organizzazione degli intellettuali rispondente alle esigenze di un gruppo dominante, di un' eletta politica, la quale in un primo tempo, al pari delle teocrazie, si identificò e fu una cosa sola con i proprii intellettuali”.

${ }^{61} \mathrm{O}$ testemunho de Aristóxeno sobre o pai etrusco de Pitágoras encontra-se, entre outros, em Plutarco Quaest. Conv. VIII; 7, 1.

62 Orig.: Quin etiam arbitror propter Pythagoreorum admirationem Numam quoque regem Pythagoreum a posterioribus existimatum. Nam cum Pythagorae disciplinam et instituta cognoscerent regisque eius aequitatem et sapientiam a maioribus suis accepissent, aetates autem et tempora ignorarent propter vetustatem, eum, qui sapientia excelleret, Pythagorae auditorem crediderunt fuisse (Cicero. Tusc. Disp. IV: 1-2). 78).

${ }^{63}$ Orig.: incolae paene nostros, qui essent italici philosophi quondam nominati (Cato Maior XXI:

${ }^{64}$ Tito Livio recorda, nesse sentido, um fato muito significativo: foi achada, em Roma, em 181 EC, uma caixa contendo livros que se pensavam ter sido escritos pelo próprio Numa (Liv. XL: 29). Definidos como pitagóricos, dedicados a temáticas religiosas e sapienciais, foram queimados (sic) a mando das autoridades, que temiam ameaças à religião oficial. 
outras fontes menores, contudo, manteve viva a tradição de Pitágoras: Ambrósio lembra os ditos pitagóricos e diversos placita; Agostinho, que inicialmente abundava em citações e referências a Pitágoras e à filosofia pitagórica, acaba, todavia, voltando atrás, e afirma: "eu acreditava que não houvessem erros na tal doutrina pitagórica, mas são muitos e até capitais" (Retr., PL 32: col589). ${ }^{65}$ Tanto ele como também Tertuliano e Latâncio não deixam de lembrar os erros do samius sophista: in primis - como não podia ser diferente - a teoria da metempsicose. ${ }^{66}$

O Quattrocento italiano marca um franco "revival" da tradição itálica de Pitágoras, na esteira da recuperação do platonismo. Nesse sentido, a recuperação das fontes latinas exerce um papel fundamental. Assim, a partir da primeira Vida de Pitágoras, escrita por Baldi em vulgar (1888), por meio da recuperação da figura de Pitágoras por Petrarca (Triumphus fame III: 7-8), há uma lenta apropriação do pitagorismo. Esta não se limita a um exercício literário, mas alcança também uma dimensão especulativa com Nicolau de Cusa: o erudito intelectual da Igreja Romana utiliza para sua teologia negativa a aritmogeometria pitagórica do Timeu e da República. A doutrina da trindade é também referida a Pitágoras: "esta é aquela unidade trina que Pitágoras, primeiro entre todos os filósofos, glória da Itália e da Grécia, nos ensinou a adorar" (Cusano 1972: 68). ${ }^{67}$

Duas figuras intelectuais italianas de primeira ordem, desse período, dedicam-se ao pitagorismo: Marcílio Ficino e Pico della Mirandola. O primeiro, procurando colocar a Florença dos Médici no interior da história intelectual ocidental como sucessora de Atenas (e Roma) e a si mesmo como continuador da Academia, empreende o projeto de tradução do corpus platônico fortemente influenciado pela exegese neopitagórica. Dessa forma, já na sua introdução à tradução de Plotino, Ficino resume o lugar que reserva para Pitágoras nessa história:

A sagrada filosofia nasceu sob Zoroastro entre os Persas, sob Mercúrio entre os Egípcios, tanto aqui como lá coerente e conforme com si mesma; cresceu depois entre os Trácios sobre Orfeu e Aglaofemo, foi adolescente entre os gregos e os itálicos sob Pitágoras e tornou-se adulta, em Atenas, sob o divino Platão (Ficino 1576: 1537). ${ }^{68}$

65 Orig.: me credidisse nullos errores in Pythagorica esse doctrina, cum sint plures, iidemque capitales (August. Retr., PL 32: col. 58-9).

${ }^{66} \mathrm{Cf}$., para os autores citados, as seguintes páginas: Tertuliano, De Anima, PL 2: col. 697701; Latâncio, Div. Inst., PL 6, col. 405-9 e De vita beata, PL 6: col. 777; Agostinho, Contra Acad., PL 32: col. 954; Ambrósio. In salm., PL 15: col. 1275.

${ }^{67}$ Orig.: "Questa è quella unità trina che Pitagora, primo tra tutti i filosofi, gloria d'Italia e di Grecia, ci ha insegnato ad adorare".

${ }^{68}$ Orig.: Divina providentia volente videlicet omnes pro singulorum ingenio, ad se mirabiliter revocare, factum est, ut pia quaedam philosophia quodam et apud Persas sub Zoroastre, et apud Aegyptios sub Mercurio nasceretur, utrobique; sibimet consonas: nutriretur deinde apud Thraces sub Orpheo atque Aglaophemo: adolesceret quoque mox sub Pythagora apud Graecos et: in Italos tandem vero a Divo Platone consumaretur Athenis (Ficino 1576: 1537). 
Em outro passo, em que reconstrói uma genealogia da filosofia antiga, ou, melhor, da prisca theologia, que antecipa a filosofia propriamente dita e parte de Hermes Trismegisto, Pitágoras aparece novamente em primeiro plano:

[A Hermes] seguiu Orfeu, ao qual foram atribuídas as partes seguintes da teologia antiga; a Aglaofemo, que havia sido iniciado aos ritos sagrados de Orfeu, sucedeu depois na teologia Pitágoras, do qual Filolau foi discípulo, o mesmo que foi preceptor de Platão. Portanto, uma única seita de filosofia antiga, em todo lugar coerente consigo mesma, foi instituída por seis teólogos, em uma ordem maravilhosa, que é inaugurada por Mercúrio e se cumpre plenamente com o divino Platão (Ficino 1576: 1836). ${ }^{69}$

O lugar de Pitágoras como priscus philosophus, nesse panorama articulado por sabedorias outras, pressupõe a mesma visão universalista que Pico della Mirandola desenvolverá em seguida: a de uma articulação da filosofia pitagórica com a Cabala, os Oráculos Caldaicos e a sabedoria árabe. Pico, mestre da concórdia, preparava-se para discutir, em Roma, novecentas proposições retiradas das mais diversas tradições sapienciais quando, com a urgência que todo pesquisador bem conhece, pede desesperadamente a Ficino que lhe empreste o códice que continha a Vida Pitagórica, de Jâmblico: "neste momento muito necessário aos meus estudos" (hoc tempore ad mea studia plurimum necessarium - 1572: 361), exatamente por considerar o pitagorismo como a ponte principal para a sabedoria antiga oriental.

A economia dessas páginas não permitirá seguir mais de perto este caminho itálico da tradição sobre o pitagorismo. ${ }^{70} \mathrm{O}$ que interessa mais imediatamente anotar aqui é que modernos historiadores italianos recuperam essa tradição de estudos sobre a política pitagórica no interior dos estudos arqueológicos e históricos sobre a Magna Grécia, como é o caso de Prontera (1976; 1977), Mele (1982: 2000, 2007) e Musti (1990). Contudo, isso vale também para historiadores da filosofia: entre eles, além do já citado Ferrero (1955), destacam-se os estudos a este respeito de Casertano (1988 e 2009) e os sóbrios capítulos dedicados ao tema por Centrone (1996). Especialmente

${ }^{69}$ Trata-se aqui do Argumentum Marsilij Ficini Florentini, in librum Mercurij Trismegisti, ad Cosmum Medicem, isto é, da carta dedicatória dirigida a Cosimo de Medici em ocasião da tradução dos primeiros 14 opúsculos do Corpus Hermeticum. Assim, no original: cum secutus Orpheus, secundas antiquae theologiae partes obtinuit. Orphei sacris initiatus est Aglaophemo successit in theologia Pythagoras, quem Philolaus sectatus est, divi Platonis nostri praeceptor. Itaque una priscae theologiae undique sibi consona secta, ex theologis sex miro quodam ordine conflata est, exordia sumens a Mercurio, a divo Platone penitus absoluta. O que Ficino aqui quer realizar foi definido de forma instigante como uma arqueologia do saber, em busca dos textos e dos autores de referência mais antigos para explicar a sucessiva história do pensamento (Tambrun-Krasker 1999: 20-22).

${ }^{70}$ É certamente o caso, para isso, de seguir o percurso bem traçado por Casini (1998), entre outros. Para a influência do pitagorismo sobre a arte e a arquitetura da Europa renascentista, cf. agora a amplíssima monografia de Joost-Gaugier (2009), que concorda com a primazia italiana no revival pitagórico acima descrito: "the enlivening inspiration of Pythagoreanism spread primarily from Italy, where interest in ancient works was at first most intense, to the rest of Europe" (2009: 240). 
relevante é a contribuição de Musti (1990) que evidencia nas fontes sobre as revoltas antipitagóricas uma característica de acronia, que permitiria resolver a espinhosa questão cronológica (além de topográfica) das revoltas:

A narração dos fatos apresenta-se com uma viscosa continuidade. [...] À análise atenta daquilo que se tem por detrás, esta narração revela uma modalidade particular (bem mais que uma simples contradição) do formar-se das tradições pitagóricas e sobre o pitagorismo (Musti 1990: 38). ${ }^{71}$

A solução proposta por Musti é a de considerar que as condições culturais, nas quais se desenvolve a literatura pitagórica, não criavam as condições para uma verificação crítica das fontes em relação às patentes contradições cronológicas e topográficas: notadamente, Musti indica no sectarismo, na diáspora dos pitagóricos e na circulação oral das memórias os motivos centrais dessa acronia da tradição (1990: 39).

Um capítulo à parte merecem as tentativas de Rostagni (1922), antes, e de De Vogel (1964), posteriormente, de creditar validade historiográfica à definição do papel político do próprio Pitágoras aos célebres quatro discursos políticos que teria proferido quando de sua chegada em Crotona. A história da tradição e da crítica moderna desses quatro lógoi é extremamente significativa para a compreensão da tentativa de negação da relevância da política pitagórica da qual se falava.

A redação completa dos quatro discursos, referida por Porfírio (VP: 18), citando Dicearco, é presente em Jâmblico (VP:37-57), que, por sua vez, devia ter como fontes Timeu, provavelmente via Apolônio de Tiana. ${ }^{72}$ Rostagni (1922), concentrado em um escólio de Antístenes ao primeiro verso da Odisseia, a propósito da polytropia de Ulisses, no interior de uma interessantíssima (e ainda pouco explorada) hipótese de trabalho que conecta o pitagorismo às origens da retórica (de maneira especial a Górgias), empenha-se em conferir confiabilidade ao testemunho de Dicearco sobre os lógoi de Pitágoras. A intenção declarada é a de superar a tese clássica de Rohde, mencionada anteriormente, pela qual a tradição teria sido inventada por Dicearco, que assim teria criado a figura de um Pitágoras educador político como modelo anacrônico da vida prática peripatética. Dessa criação derivariam depois tanto os testemunhos de TimeuApolônio quanto a redação dos discursos em Jâmblico (1871: 561; 1872: 27). A essa tese, Rostagni (1922: 151) opõe a "evidência" de um testemunho de Antístenes relativo à tradição dos discursos de Pitágoras:

Antístenes diz que Homero nem louva nem critica Ulisses, chamando-o polýtropos [...]. Por esse motivo deu a Ulisses o epíteto de polýtropos: pois sabia conversar com os homens de muitas maneiras. Assim, narra-se que Pitágoras,

${ }^{71}$ Orig.: "Il racconto dei fatti si presenta con una vischiosa continuità. [...] All' analise attenta di quello che c' è dietro, questo racconto rivela un modo particolare (assai più che una occasionale contraddizione) di formarsi delle tradizioni pitagoriche e sul pitagorismo".

${ }^{72}$ Bertermann (1913), Zucconi (1970), Centrone (1996), Brisson e Segonds (Jamblique 1996). 
convidado a proferir discursos às crianças, compôs para elas discursos infantis (lógoi paidikoi), e para as mulheres outros adequados às mulheres, e para os arcontes arcónticos, e para os efebos, efébios. Pois encontrar o tipo de sabedoria conveniente para cada um é próprio da sapiência. Ao contrário, é sinal de ignorância utilizar-se de uma só forma de discurso (monotrópos toû lógou) com aqueles que estão variavelmente dispostos (Schol. In Hom. Odyss. I, 1: 50-63).

Sua solução pressupõe a compreensão de uma genealogia do lógos e da retórica que remonta suas origens ao pitagorismo:

É muito útil considerar que a tradição, acolhida por Aristóteles e pela crítica alexandrina, atribuia a Empédocles e até mesmo ao próprio Pitágoras a invenção da arte retórica. Esta tradição - que, até hoje, é considerada vazia - possui um fundamento real, na medida em que a Empédocles e aos pitagóricos deviam remontar as experiências e os preceitos relativos ao valor da psicagógico da palavra, os mesmos que depois formaram a base da téchne de Górgias (Rostagni, $1922,149) \cdot{ }^{73}$

Assim, o escólio e os lógoi acima citados confirmariam essa vocação político-retórica do pitagorismo, em estreita conexão com um modelo bastante pragmático de relação entre política e filosofia como aquele da primeira sofística. $^{74}$

De Vogel (1966) empenha-se em amplo estudo dos quatro lógoi em busca da definição de uma imagem pré-zelleriana - a terminologia é de Thesleff (1968: 298) - de Pitágoras como educador político, no interior, todavia, de uma visão dele que seja onicompreensiva das diversas imagens transmitidas pela história, diferentemente do homônimo e contemporâneo trabalho de Philip (1966), que confia unicamente a Aristóteles a construção de uma imagem de Pitágoras e do pitagorismo antigo centrada no ensino moral. De Vogel reforça os argumentos já citados de Rostagni baseando-se supostamente em argumentação de Thesleff (1961), segundo a qual haveria uma continuidade ininterrupta da escola pitagórica no sul da Itália desde o início até o século IV a.C. ${ }^{75}$ Essa continuidade permitiria considerar como relevante uma parte

${ }^{73}$ Orig.: "È assai utile considerare che la tradizione, accolta da Aristotele e dalla critica alessandrina, attribuiva ad Empedocle e perfino a Pitagora stesso, l'invezione dell'arte retorica. Questa tradizione - che fino ad oggi si considera vacua - ha un reale fondamento, nel senso che ad Empedocle e ai Pitagorici dovevano risalire gli esperimenti e precetti riguardanti il valore psicagogico della parola, che formarono poi la base della téchne di Gorgia”. E ainda, segundo Rostagni, o surgimento da retórica "rappresentava un'evoluzione verificatasi nel seno stesso del pitagorismo pel naturale procedere della scienza e dello spirito greco" (1922: 169).

${ }_{74}$ Não será obviamente aqui possível seguir toda a argumentação de Rostagni. Remete-se para isso a uma recente discussão da posição de Rostagni em Cornelli (2010, 24-25).

75 Ainda que Thesleff, em sua resenha ao livro de De Vogel, não reconheça ter afirmado esta continuidade: "[De Vogel's] account of the argumentation in my Introduction (1961) is however somewhat misleading. For instance, I did not argue, as would appear from d. V. p. 28 ff., that the Pythagorean school continued to live on in Southern Italy from the end of the 4th century. Certainly there was a break in the tradition. And I did not lay stress on the evidence of the pentagrams" (Thesleff 1968: $300 \mathrm{nI}$ ). 
do material das Vidas helenísticas, e - certamente - devem ser assim pensados os testemunhos da atividade política de Pitágoras fornecidos pelos lógoi. As críticas contra essa lectio de Rostagni e De Vogel não demoraram (Thesleff 1968, Kerferd 1965 e Feldman 1968): paralelos com apócrifos dóricos e outros sinais textuais indicam imediatamente uma necessária prudência no tratamento das conclusões de De Vogel. O que mais importa, talvez, é aquilo sublinhado por Centrone (1996), isto é, a existência, nas fontes, de sinais dessa atividade político-retórica independentemente da antiguidade ou menos dos lógoi:

Um núcleo originário historicamente confiável, confirmado inclusive por alguns acenos à história local e à topografia de Crotona, assim como um reflexo histórico da organização societária da aristocracia arcaica tem-se na rígida divisão de grupos sociais, aos quais Pitágoras profere discursos separadamente (coisa que é atestada por todas as fontes) (Centrone 1996: 31). ${ }^{76}$

De Vogel (nas pegadas de Rostagni) certamente contribui para recolocar no devido lugar, no interior da literatura histórico-filosófica, a discussão sobre a dimensão política do pitagorismo desde suas origens. Com uma vantagem comparativa inestimável: a de obrigar, daqui para frente, a considerá-la como parte integrante de uma imagem complexa, articulada juntamente com as dimensões científica e religiosa do pitagorismo.

${ }^{76}$ Orig.: "un nucleo originario storicamente attendibile, confermato peraltro da alcuni accenni alla storia locale e alla topografia di Crotone, così come un riflesso storico dell'organizzazione societaria dell'aristocrazia arcaica si ha nella rigida divisione dei gruppi sociali, ai quali Pitagora tiene discorsi separatamente (cosa che è attestata da tutte le fonti)". 


\subsection{O testemunho único de Aristóteles e A INCERTA TRADIÇÃO ACADÊMICA}

A história da crítica dedicou-se, desde o começo, também à análise da imagem do pitagorismo antigo que resulta das fontes indiretas, isto é, tanto das pretensas polêmicas antipitagóricas de autores contemporâneos como das influências e das referências de autores posteriores ao movimento (Zeller e Mondolfo 1938: 313-364).

Nessa busca, a obra de Tannery (1887b ) é certamente o primeiro passo: sua tese central é que a seção da dóxa do Poema de Parmênides seria um desenvolvimento argumentativo dedicado à refutação da cosmologia pitagórica. Tannery parte da observação pela qual no começo da seção da dóxa, no Poema, Parmênides não poderia senão referir-se aos pitagóricos:

Já disse que o prólogo de Parmênides sobre a opinião (v. 113-121) nos joga em pleno pitagorismo; sobretudo o último verso parece-me digno de atenção. Parmênides quer fazer conhecer a ciência tal qual é professada por seus contemporâneos; mas, na Itália, somente os pitagóricos gozam de uma reputação de ciência. Pelo fato de não termos provas decisivas de que o Eleata preocupa-se com os Jônicos, nos achamos no direito de pensar que não visa a outros senão os Itálicos (Tannery 1887b: 226). ${ }^{77}$

Da mesma forma, a polêmica de Zenão (como também a de Xenófanes, antes) seria dirigida diretamente contra a teoria dos números pitagóricos, pois este "tira consequências totalmente novas, e notadamente aquelas sobre a unidade, a continuidade, a imobilidade do universo, contradizem as doutrinas dos pitagóricos" (Tannery 1887b:250). ${ }^{78} \mathrm{O}$ ponto central da discordância estaria na definição do que seria um ponto:

Então, qual foi o ponto fraco reconhecido por Zenão nas doutrinas pitagóricas de seu tempo? De que modo as apresenta como sendo uma afirmação da pluralidade das coisas? A solução nos é dada de uma famosa definição do ponto matemático, definição ainda clássica na época de Aristóteles, mas à qual os historiadores não deram muita atenção. Para os pitagóricos o ponto é a unidade que tem uma posição, ou, dito de outra maneira, a unidade considerada no espaço. Resulta imediatamente desta definição que o corpo geométrico é uma pluralidade, soma de pontos, da mesma forma como o nome é uma pluralidade, soma de unidades. No entanto, essa proposta é absolutamente falsa [...] (Tannery 1887b: 250, grifo do autor). ${ }^{79}$

${ }^{77}$ Orig.: "J'ai déjà dit que le début de Parménide sur l'opinion (v. 113-121) nous jette en plein pythagorisme. Le dernier vers surtout me parait digne d'attention. Parménide veut faire connaître la science telle que la professaient ses contemporains; mais, en Italie, seuls les pythagoriens avaient une réputation de science. Tant que nous n'aurons pas de preuve décisive que l'Eléate se préoccupe des Ioniens, nous axons droit de penser qu'il ne vise que les Italiques".

${ }^{78}$ Orig.: "il tirait des conséquences toutes nouvelles, et notamment celles sur l'unité, la continuité, l'immobilité de l'univers contre-disaient les doctrines pythagoriennes".

${ }^{79}$ Orig.: "Quel était donc le point faible reconnu par Zenon dans les doctrines pythagoriennes de son temps? de quelle façon le présente-t-il comme étant une affirmation de la pluralité des 
Essa posição pitagórica passou a ser chamada de atomismo numérico e encontra diversas aproximações com o atomismo dos séculos V e IV a.C. ${ }^{80}$

Segundo Tannery (1887b:, 251), o sucesso de Zenão teria sido a tal ponto avassalador que os pitagóricos nem sequer puderam esboçar alguma tentativa de contestação. ${ }^{81}$

O problema dessa reconstrução é que carece, em boa parte, de fundamentação histórica. Certamente, devemos concordar com Burkert quando sugere que a imagem de um diálogo - todo pré-socrático - entre o pitagorismo e outras escolas, apesar de muito tentador, é carente de bases textuais sólidas:

Dessa forma, pode ser construído um capítulo tentador da história da filosofia; massas erráticas e cascalho inidentificável unem-se em uma estrutura abrangente. A suspeita interação entre eleatas e pitagóricos, em particular, torna-se um diálogo vivo. Parmênides, o pitagórico apóstata, configura seu próprio sistema em oposição àquele da escola; em resposta, os pitagóricos revisam suas teorias, apenas em tempo para ser submetidas a novos ataques por parte de Zenão; isso os obriga a empreender uma nova revisão [...] (sic) Essa estrutura, no entanto, repousa sobre uma base instável (Burkert 1972: 278). .82

De fato, ainda que seja bastante provável que outros pensadores da Magna Grécia tenham recebido forte influência pitagórica, uma sólida abordagem histórica não pode se basear em probabilidades e plausibilidade, pois "unicamente um estudo meticuloso da evidência interna e externa pode levantar esta possibilidade para um patamar de probabilidade - para não dizer de certeza" (Burkert 1972: 280). ${ }^{83}$

choses? La clef nous est donnée par une célèbre définition du point mathématique, définition encore classique au temps d'Aristote, mais que les historiens n'ont pás considérée assez attentivement. Pour les pythagoriens, le point est l'unité ayant une position, ou autrement l'unité considérée dans l'espace. Il suit immédiatement de cette définition que le corps géométrique est une pluralité, somme de points, de même que le nombre est une pluralité, somme d'unités. Or, une telle proposition est absolument fausse [...]".

${ }^{80}$ Para uma discussão mais geral da relação do pitagorismo com Demócrito e o atomismo, cf. Zeller e Mondolfo (1938: 332-335); Alfieri (1953: 30-54); Gemelli (2007a: 68-90).

${ }^{81}$ Tanto Cherniss (1935: 215) quanto Lee $(1936: 34,104)$ seguem as linhas-mestras da interpretação de Tannery da polêmica zenoniana.

${ }^{82}$ Orig.: "In this way a tempting chapter of the history of philosophy may be built; erratic boulders and unidentifiable gravel coalesce into a comprehensive structure. The suspected interaction of the Eleatics and Pythagoreans, in particular, becomes a living dialogue. Parmenides, the apostate Pythagorean, sets up his own system in opposition to that of the school; in response, the Pythagoreans revise their theories, only to be subjected to new attacks, by Zeno; this forces them to undertake further revision [...] (sic) This structure, however, rests on a shaky foundation".

${ }^{83}$ Orig.: "only meticulous study of the internal and external evidence can raise this possibility to a probability to say nothing of certainty". Cf. Casertano (2007b: 4) para um exemplo de discussão da influência pitagórica sobre Parmênides. 
Ainda que marcado pelas imprecisões anteriormente indicadas, esse primeiro passo tornou possível não somente trazer para a discussão sobre a Quellenforschung diversos textos antigos, como também começar a colocar em questão a presunção do testemunho único de Aristóteles. Não obstante, a importância da tese de Tannery faz que, de Kranz (Diels-Kranz 1951) até Raven (1948), a maioria dos comentadores se proponha seguir um diálogo entre eleatismo e pitagorismo, utilizando-se das fontes mais antigas para isso. ${ }^{84}$

Acenou-se há pouco a presunção de validade do testemunho único de Aristóteles. Um papel central nessa reavaliação do testemunho aristotélico sobre os pré-socráticos (e depois sobre Platão) é desempenhado certamente pelos trabalhos de Cherniss (1935: 1944): por meio de um agudo trabalho sobre as fontes, ainda hoje insuperado, Cherniss chega a concluir, já em 1935, que:

Aristóteles não está, em nenhum dos trabalhos que possuímos, procurando fornecer um relatório da filosofia mais antiga. Ele está usando essas teorias como interlocutoras em um debate artificial que ele prepara para que conduza 'inevitavelmente' às suas próprias conclusões (Cherniss 1935: xii).85

Cherniss, dessa forma, analisa os procedimentos historiográficos de Aristóteles em busca de uma solução ao problema central que o corpus constitui para a reconstrução da filosofia pré-socrática: apesar de pouco confiável em sua reconstrução das teorias dos primeiros filósofos, suas constantes contradições, omissões, erros e desentendimentos, Aristóteles é ainda a principal, senão a única, fonte para o estudo dos pré-socráticos (1935: 347-350). Dessa forma, caberá ter aquilo que Cherniss chama de "o maior cuidado" (the greatest care) na análise do material aristotélico.

Com esse intuito, Cherniss irá desenvolver uma metodologia de abordagem ao texto que lhe permitirá definir procedimentos para uma espécie de controle de viés (para utilizar uma terminologia estatística) que busca identificar fatores de confusão, permitindo definir um uso acertado, isto é, adequado do ponto de vista historiográfico, do corpus: dois tipos de omissões, sete fontes comuns de erros etc. (1953: 351-358).

Dois erros são especialmente importantes por modelar profundamente toda a história da crítica dos pré-socráticos. O primeiro diz respeito à concepção de Aristóteles de que os pré-socráticos teriam fundamentalmente

${ }^{84}$ Cf. Diels-Kranz (1951: 226); Zeller e Mondolfo [(1938: 326) - na nota sobre as fontes de Mondolfo, pois Zeller, assim como Gomperz (1893), não concordava com isso]; Burnet (1908: 183); Rey (1933: 183); Cornford (1939: I); Raven (1948: 211). Contrários a essa tese, Reinhardt (1916: 24, 69, 85) e Calogero (1932: 28) consideram a seção da dóxa como derivação interna à própria metafísica de Parmênides.

${ }^{85}$ Orig.: "Aristotle is not, in any of the works we have, attempting to give a historical account of earlier philosophy. He is using these theories as interlocutors in the artificial debates which he sets up to lead 'inevitably' to his own solutions”. Cf. também Cherniss (1935: 349-50, 356-357). Já Burnet (1908: 56) havia começado a suspeitar das escolhas editoriais de Aristóteles, falando do costume deste de agir "putting things in his own way, regardless of historical considerations". 
um único problema ao qual dedicaram sua investigação, isto é, o da matéria que constitui todas as coisas que são. Ao contrário, olhando mais atentamente (o mesmo Aristóteles não negaria isso), é possível reconhecer os pré-socráticos empenhados na tentativa de compreensão e descrição de diversos processos e problemas específicos. O segundo erro depende do primeiro, pois constitui o motivo pelo qual Aristóteles quis restringir a riqueza e a complexidade dos temas tratados pelos pré-socráticos a uma única Grundfrage - como diria Hegel (a citação dele, como se verá, não é casual): no sistema aristotélico, a divisão fundamental da natureza dá-se entre matéria e forma. E se Platão é visto como um partidário exagerado da causa formal, o é exatamente por opor-se aos pré-socráticos, dos quais constituiria a antítese. Jogando assim um contra os outros, Aristóteles reserva para si mesmo o confortável lugar de sintese, resultado filosófico do agôn dos dois momentos anteriores a ele. ${ }^{86}$

É certamente o caso de anotar, finalmente, que a contribuição de Cherniss para a historiografia dos pré-socráticos é inquestionável, ao ponto de ser possível considerar que, depois dele, os estudos dos pré-socráticos tenham se tornado uma luta incessante com Aristóteles, ainda que certamente não contra ele.

$\mathrm{Na}$ esteira de Cherniss, diversos comentadores poderão em seguida concordar com o fato de que "Aristóteles é totalmente alheio à concepção moderna de história da filosofia" (Reale 1968: I, 151), e considerar assim Aristóteles como um testemunho necessário, mas a ser tratado com todos os cuidados possíveis. ${ }^{87}$ Laks (2007: 230) resume a historiografia da filosofia pré-socrática após Cherniss como um processo de "desaristotelização da escrita sobre as origens da filosofia grega" ${ }^{88} \mathrm{~A}$ economia destas páginas não permite, obviamente, aprofundar como mereceria essa questão da validação do testemunho aristotélico como tal, com suas consequências para a historiografia da filosofia em suas origens.

Cabe somente sublinhar, como um novo marco para a questão, um recente artigo de Collobert (2002) que, pretendendo reabrir a questão, desafia, a seu modo, o consenso estabelecido a partir de Cherniss. Collobert revela como Aristóteles estaria seguindo ante litteram, em sua historiografia dos présocráticos, os princípios de uma lectio analítica (no sentido contemporâneo de não-continental). Por esse motivo, à pergunta se Aristóteles deva ser considerado um historiador da filosofia, ela continua respondendo, ainda que com diversos distinguos, que não. Pois

Aristóteles não escreveu uma história da filosofia em sentido moderno ou, ao menos, no sentido 'continental' quando ele transmitiu os pensamentos de seus

${ }^{86}$ Cherniss (1935: 349) não deixa de anotar a dependência deste método agônico e aporético de Aristóteles de seus mestres: indiretamente Sócrates, mas, sobretudo, Platão.

${ }^{87}$ Orig.: "il moderno concetto di storia della filosofia è totalmente estraneo ad Aristotele". Por outro lado, Mansfeld afirma com razão que os primeiros passos de uma historiografia da filosofia são anteriores ao próprio Aristóteles, podendo ser encontrados na literatura sofística: "the rudimentary beginnings of the historiography of Greek philosophy may be dated to the period of the Sophists” (Mansfeld 1990: 27).

${ }^{88}$ Orig.: "désaristotélisation de l'écriture des débuts de la philosophie grecques". 
predecessores. Por essa razão, alguém poderia dizer, com Wilamowitz, que "não se deve culpar o historiador Aristóteles, pois Aristóteles jamais foi ou quis ser um historiador (Collobert 2002, 294-295). ${ }^{89}$

De fato, Aristóteles, em sua Metafísica, no que diz respeito aos pitagóricos, parece não somente querer tratá-los de certa forma separadamente em relação aos outros pré-socráticos (985b 23ss), mas também, em constante intenção polêmica contra o platonismo, compara-os o tempo todo com este último (Met. 987a 29ss, 989b 29ss; 990a 27ss, 996a 4s): dessa forma, o pitagorismo torna-se mais uma ocasião para atacar os argumentos platônicos (Met. 1083b 8ss; 1090a 30) do que um tópico de interesse per se. ${ }^{90}$

Porquanto essa aproximação entre o pitagorismo e o platonismo obedeça, em Aristóteles, a uma precisa estratégia polêmica, a crítica, ainda no interior do esforço de validação das fontes indiretas sobre o pitagorismo, tentou explorar as relações dos pitagóricos com Platão. Para além das relações históricas deste com o rei-filósofo Arquitas de Tarento, como testemunharia, entre outras fontes, a própria Carta VII (339d), uma já antiga tentativa de avaliação dos diálogos platônicos como fontes históricas confiáveis levaria a aprofundar radicalmente a dependência de Platão em relação aos pitagóricos. Tanto Burnet (1908) quanto Taylor (1911), por considerarem de fato os diálogos platônicos como testemunhos históricos, chegam a fazer diversos deles dependerem diretamente da influência pitagórica: dessa forma, o Sócrates do Fédon revela-se pitagórico, defensor da metempsicose e da anamnese (Taylor 1911: 129-177); enquanto o Timeu aparecerá como uma obra quase que completamente informada pelo pitagorismo (Burnet 1908: 340ss.). ${ }^{91}$

Obviamente os resultados dos esforços sobre as fontes indiretas estão bem longe de serem consensuais. De fato, já Frank (1923) - em direção totalmente

${ }^{89}$ Orig.: "Aristotle did not write a history of philosophy in a modern sense or at least in a 'continental' sense when he transmitted the thoughts of his predecessors. For this reason, one can say with U. Wilamowitz that 'one does not have to blame the historian Aristotle, because Aristotle never was nor wanted to be an historian"'. A Collobert deve ser reconhecida a intenção de recolocar em termos mais atuais (os termos da querelle analítico-continentais) a questão. Todavia, grande parte de sua solução hermenêutica é ainda dependente do excelente trabalho de Cherniss (1935), como demonstra, por exemplo, a seguinte afirmação deste em relação aos testemunhos contidos no corpus aristotélico: "one cannot safely wrench them away to use as building-blocks for a history of Presocratic philosophy. There are no 'doxographical' accounts in the works of Aristotle, because Aristotle was not a doxographer but a philosopher seeking to construct a complete and final philosophy" (Cherniss 1935: 347). É esta ainda uma boa descrição ante litteram do Aristóteles analítico de Collobert.

${ }^{90}$ Sobre a lectio aristotélica do pitagorismo antigo, será o caso de voltar obviamente, em seguida, a anotar seus problemas e sucessos. É suficiente por enquanto lembrar que, tanto na Física quanto no De Caelo, Aristóteles dedica alguns comentários às doutrinas científicas dos pitagóricos, assim como - na mesma Metafísica (986a: 12) - refere-se a uma mais exata discussão sobre estes. A referência seria aos famosos dois livros (perdidos) que ele dedicara especificamente ao pitagorismo. Para as fontes dessa tradição e uma exaustiva discussão historiográfica destas, cf. Burkert (1972: 29).

${ }^{91}$ Da mesma forma, a tese doutoral de Cameron (1938) sugere uma base pitagórica para a teoria da anamnese. 
contrária ao colocado acima e, de certa forma, radicalizando o ceticismo zelleriano - considera impossível qualquer tentativa de acessar a tradição pitagórica antes de Platão. Sua obra intitula-se significativamente Plato und die sogenannten Pythagoreer ("Platão e os assim chamados pitagóricos"), pois apoia sua argumentação de maneira muito decidida na repetida referência de Aristóteles aos kaloúmenoi pitagóricos: segundo Frank, Aristóteles estaria se referindo a pitagóricos do século IV aEC, como Arquitas, para além dos próprios acadêmicos, entre eles Espeusipo (Frank 1923: 77). O pressuposto geral de Frank é que não se pode imaginar um pensamento científico no mundo grego antes de Anaxágoras:

Anaxágoras foi o primeiro a formular o princípio da ciência moderna, distinguindo, em suas investigações ópticas, a imagem do mundo subjetivapsicológica pelo ponto de vista objetivo de um observador absoluto (1923, 144). ${ }^{92}$

Dessa forma, tudo o que diz respeito aos pitagóricos deverá ser considerado invenção de Espeusipo e dos primeiros acadêmicos. Por consequência, tanto os fragmentos de Filolau como toda a teoria matemática deverão ser reconduzidos para o período acadêmico. O hipercriticismo de filólogos como Frank é confrontado veementemente por Santillana e Pitts: para eles, Frank é o ponto de partida de uma escola de historiadores que

Foram atraídos para a companhia de vários filólogos modernos, que haviam caído na armadilha de aceitar alguns dos argumentos destrutivos de Frank, sem compreender a íntima dependência destes de sua inaceitável alternativa (Santillana e Pitts 1951: 112).93

Ao longo de todo o percurso historiográfico em busca das fontes indiretas sobre o pitagorismo, a lectio communis parece ter sido exatamente aquela de um ceticismo por parti pris, que revela de um lado certa postura todo-poderosa dos estudiosos de Platão e Aristóteles, que tendem a considerá-los como inventores de praticamente qualquer ideia que tenha aparecido antes deles,

${ }^{92}$ Orig.: "Anaxagoras formuliert zuerst das Prinzip der modernen Wissenschaft, indem er das unmittelbare subjectiv-psycologische Weltbild in seinen optischen Forschungen von der objektiven Anschauung eines ideellen, absoluten Beobachters unterscheidet".

${ }^{93}$ Orig.: "were attracted by the company of various modern philologists, who have been trapped into accepting some of Frank's destructive arguments without noticing their intimate dependence upon his unacceptable alternative". A alternativa à qual os autores se referem, e que constitui um dos pontos fundamentais da argumentação de Frank, é aquela entre uma origem grega e uma simples e tardia importação oriental da matemática: Frank optaria obviamente pela segunda. Por consequência: "relying on Frank, these authors have dismissed the entire tradition about early Greek mathematics, and supplanted it either with a most improbably late transference of Babylonian mathematics to Greece in the Vth century" (Santillana e Pitts 1951: 112). Para uma resenha desta questão, cf. Salas (1996). Thesleff $(1961 ; 45)$ reclama da veemência de Santillana e Pitts, por causa da "ridicularização irreverente" de Frank por parte dos dois autores. Estes de fato afirmaram que, se quisermos ser coerentes com o hipercriticismo de Frank (1951: 116), "we may begin to suspect Frank himself of being an imaginary character in the lost dialogues of George Santayana”. 
O pitagorismo como categoria historiográfica

à custa de uma atenta análise das fontes pré-socráticas; por outro lado, certa preguiça da pesquisa sobre as origens do pensamento grego, que prefere repetir os chavões manualísticos a empenhar-se em uma atenta revisão das práticas normais de pesquisa. 


\subsection{De Burkert a Kingsley: TERCEIRA-VIA E MISTICISMO NA TRADIÇÃO PITAGÓRICA}

Uma verdadeira terceira-via para a crítica, entre o ceticismo zelleriano (na versão extremizada por Frank) e uma excessiva confiança nas fontes que sempre assola os estudiosos menos advertidos do pitagorismo, é constituída pelo trabalho de Walter Burkert dedicado ao pitagorismo, Weisheit und Wissenschaft, traduzido posterioremente por Minar (Burkert 1972) para o inglês e publicado em edição revisada como Lore and Science in Ancient Pythagoreanism. Ponto de referência obrigatório, desde então, para qualquer percurso crítico dedicado ao estudo do pitagorismo, a obra de Burkert revela, no mesmo processo de sua confecção, o difícil caminho da validação das fontes a serem utilizadas para apresentar a filosofia do pitagorismo. No prefácio à primeira edição de Weisheit und Wissenschaft, em 1962, Burkert revela fundamentalmente uma postura cética em relação à efetiva contribuição do pitagorismo para os avanços da matemática grega antiga, notadamente na questão dos irracionais, referindo a sabedoria dos números pitagóricos a um ambiente intelectual pré-científico:

Nesse período de penumbra entre antigo e novo, quando os gregos, em um feito historicamente único, estavam descobrindo a interpretação racional do mundo e as ciências naturais quantitativas, Pitágoras representa não a origem do novo, mas a sobrevivência ou o renascimento da sabedoria antiga, pré-científica, baseada na autoridade sobre-humana e expressa na obligatio ritual! A sabedoria do número é múltipla e mutável (Burkert 1972, Prefácio à edição alemã). ${ }^{94}$

Ao contrário, no prefácio à edição inglesa, dez anos depois, Burkert é obrigado a reconhecer que - em suas próprias palavras -: "Eu aprendi nestes anos [...] sobre a questão da 'descoberta' do irracional, e tomei uma posição que é menos crítica da tradição”. ${ }^{95}$

Para Burkert, em relação à matemática, existiria um profundo gap entre a atividade dos pitagóricos do século $\mathrm{V}$ a.C. - relegada ao mundo dos acusmata e da numerologia (ainda que se deva preferir, em âmbito acadêmico, o termo aritmologia, conforme observado por Delatte, 1915) - e aquela dos

\footnotetext{
${ }^{94}$ Orig.: "In that twilight period between old and new, when Greeks, in a historically unique achievement, were discovering the rational interpretation of the world and quantitative natural science, Pythagoras represents not the origin of the new, but the survival or revival of ancient, pre-scientific lore, based on superhuman authority and expressed in ritual obligation! The lore of number is multifarious and changeable".

${ }_{95}$ Orig.: "I have learned in these years [... about the question of the 'Discovery' of the irrational, I have taken a stand which is less critical of the tradition”. Não é a intenção, neste momento, dar conta da ampla tradição crítica sobre a contribuição do pitagorismo para a matemática e sobre o desenvolvimento da teoria dos números no interior da filosofia pitagórica. Estudos clássicos da questão são os de Tannery (1887a; 1887b), Becker (1957), Von Fritz (1945) e, sobretudo, Van der Waerden (1947-1949). Mais recentemente, podem-se conferir Huffman (1988; 1993; 2005), Zhmud (1989; 1992; 1997), Centrone (1996), Salas (1996) e Casertano (2009). Cf. a seguir, o capítulo quarto, para um desenvolvimento desta questão.
} 
matemáticos jônicos como Hipócrates de Quios. Assim, para Burkert (1972), o tipo de matemática dos primeiros pitagóricos, incluindo aqueles do século $\mathrm{V}$ a.C (e, portanto, Filolau), de maneira alguma corresponderia ao tipo de exercício dedutivo rigoroso de contemporâneos como Hipócrates de Quios e Teodoro de Cirene: aqui se trataria, ao contrário, de um culto aos números, no contexto dos acusmata, que a tradição continuamente recorda, e que poderá ser assim aproximado mais facilmente à numerologia das culturas primitivas. ${ }^{96}$

Burkert afirma serem as duas preocupações, científico-matemática e numerológica, radicalmente distintas:

Número e ciência matemática não são de maneira alguma equivalentes. Números remetem em origem para as névoas dos tempos pré-históricos, mas a ciência matemática, propriamente, não surgiu mais cedo do que na Grécia do século $\mathrm{VI}$ ou $\mathrm{V}[\mathrm{aEC}]$. As pessoas conheciam os números antes da matemática stricto sensu; e foi na era pré-científica que surgiu o "misticismo númérico", ou "simbolismo numérico" ou "numerologia", que ainda hoje continua a exercer certa influência. Ninguém pode ignorar o fato de que esse tipo de coisa estava presente no pitagorismo; Aristóteles nomeia em primeiro lugar, entre os homoiomata que os pitagóricos acreditavam subsistir entre números e coisas, a equação de certos números com dikaiosŷne, psychê kai nous e kairós (Met. 987b: 27ff) e somente com um "além disso" acrescenta a teoria matemática da música (Burkert 1972: 466). ${ }^{97}$

É preciso aqui notar que algo de muito significativo acontece na argumentação de Burkert. O ceticismo de marca zelleriana continua inspirando o tratamento das fontes: uma atenta e precisa desconstrução da doxografia acaba por chegar ao descrédito de grande parte desta como fonte direta, por indicar claramente sua origem no interior da Academia: Pláton pythagorizei (Platão pitagoriza) é o adágio fundamental que acompanha as suspeitas de

${ }^{96}$ Não faltaram revisões críticas à postura cética de Burkert a respeito das fontes sobre a contribuição dos pitagóricos à matemática. Muitas delas serão citadas nos capítulos seguintes, pois constituem um obstáculo central para qualquer interpretação do pitagorismo após 1972. Basta, por ora, lembrar a crítica sagaz que Von Fritz faz a ela em sua recensão de Weisheit: "It is not very good method to deny categorically the occurrence of an event the details of which are reported in a somewhat contradictory manner. If this methodical principle is strictly and consistently applied, it becomes possible to prove that no automobile accident ever happened" (Von Fritz 1964: 461).

${ }^{97}$ Orig.: "Number and mathematical science are by no means equivalent. Numbers go back in origin to the mists of prehistoric times, but mathematical science, properly speaking, did not emerge earlier than sixth- and fifth-century Greece. People knew numbers before mathematics in the strict sense; and it was in the pre-scientific era that the "number mysticism" arose, or "number symbolism" or "numerology", which continues even now to exert a certain influence. No one could overlook the fact that this kind of thing was present in Pythagoreanism; Aristotle names first of all, among the omoiomata which the Pythagoreans thought subsisted between numbers and things, the equation of certain numbers with dikaiosyne, psychê kai nous and kairós (Met. 987b:27ff), and only with a "furthermore" goes on to add the mathematical theory of music". 
toda a tradição (desde Met. 987a: 29).98 Daí a dificuldade em admitir uma contribuição significativa do pitagorismo aos progressos da matemática do século V a.C. A essa pars denstruens da crítica das fontes, em Burkert, segue uma hermenêutica que, articulando admiravelmente estudos de antropologia religiosa com uma sólida abordagem filológica e historiográfica, leva ao inédito resgate do Pitágoras histórico e do protopitagorismo em toda sua componente primitiva, pré-racionalista: Pitágoras deverá ter sido então um mago e xamã (ainda que cientista, ao menos à maneira dele), baseando esta sua cientificidade em um esforço para dar aquele que, para Burkert, constitui "um passo a mais" ('a step beyond'). Este passo a mais, que distinguiria Pitágoras no interior do mundo mágico-taumatúrgico primitivo, pode ser detectado, por exemplo, pela presença no interior dos testemunhos mais antigos de noções como as de kathársis e de anamnésis (1972: 211).

$\mathrm{Na}$ gangorra entre o ceticismo e a confiança nas fontes na qual todo filólogo é obrigado a movimentar-se ("a vida mesma da filologia é uma luta entre as tendências a confiar na tradição e o ceticismo com respeito à mesma" 99 - reconhece lucidamente Burkert, 1972: 9), acaba por surgir um caminho intermediário, uma terceira via, conforme foi dito, que, ainda que radicalmente cética em relação às fontes acadêmicas, consegue, todavia, desenhar uma imagem historicamente coerente e metodologicamente eficaz das origens do pitagorismo e de seu fundador.

Certamente, a obra de Burkert, com a vantagem da dupla postura acima desenhada, constitui uma pedra fundamental para a história da crítica, como bem nota Von Fritz:

O trabalho apresenta os resultados do maior esforço empreendido para resolver os problemas colocados por uma antiga tradição complicada e confusa, para chegar a uma reconstrução plausível e consistente do pensamento e das doutrinas do próprio Pitágoras (Von Fritz 1964: 459). ${ }^{100}$

Sinal inequívoco do impacto central da obra de Burkert para a história da crítica são certamente as diversas atenções e respostas que mereceu desde sua publicação. Foi especialmente seu ceticismo, mais que a reconstrução de um Pitágoras originalmente xamã, que sofreu as críticas mais precisas. Huffman sugere inicialmente que a atribuição a Filolau de uma matemática exclusivamente teológico-numerológica, conforme sugerido por Burkert, não seria um ponto pacífico (Huffman 1988: 3). O mesmo Huffman reabrirá o caso definitivamente com sua própria monografia dedicada a Filolau (Huffman 1993), dando inversamente a ele um papel proeminente, não já na matemática,

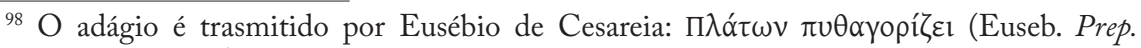
Evang. 1903:15, 37, 6).

${ }_{99}$ Orig.: "The very life of philology is the struggle between the tendencies toward faith in the tradition and skepticism of it".

${ }^{100}$ Orig.: "The work presents the results of a most energetic effort to solve the problems posed by a complicated and confused ancient tradition and to arrive at a plausible and consistent reconstruction of the thought and the doctrines of Pythagoras himself". 
e sim na filosofia da matemática antiga: "Filolau merece um lugar de destaque na história da filosofia grega como o primeiro pensador a empregar consciente e tematicamente ideias matemáticas para resolver problemas filosóficos" (Huffman 1988: 2). ${ }^{101}$

Huffman, ao contrário de Burkert, atribui a Filolau, com base fundamentalmente no fr. 4 (44 B4 DK), uma postura epistemológica, que se utilizaria dos números para compreender a realidade (Huffman 1993:64ss.) por esta última ser cognocível somente graças às relações aritmo-geométricas. ${ }^{102}$

Em outra frente, o próprio Minar, tradutor da obra para o inglês, reclama da ausência de qualquer abordagem à questão social e política (Minar 1964: 121), que se já antiga - como a discussão acima desenvolvida sobre o tema parece indicar -, deverá desempenhar um papel central na reconstrução da filosofia dos primeiros pitagóricos.

Em contrapartida, é exatamente o distanciamento que Burkert consegue estabelecer com certa precisão entre as tradições do protopitagorismo e aquelas dos pitagóricos em contato com a Academia (especialmente Arquitas) que permite, de certa forma, liberar o campo para os estudos do protopitagorismo como experiência relativamente independente das sucessivas reapropriações dela pela literatura.

O resgate de um pitagorismo das origens como fortemente marcado pelo aspecto místico-religioso é certamente inaugurado por Detienne. Este dedica ao pitagorismo diversas incursões ao longo de sua obra, definida por uma abordagem antropológica e comparativista ao mundo antigo ${ }^{103} \mathrm{~A}$ começar por seu ensaio sobre a poesia filosófica do pitagorismo antigo (1962) que, em busca de relações históricas entre poesia e metafísica, isto é, entre os ambientes dos poetas e dos filósofos antigos, ocupa-se das tradições que remetem à invenção de uma leitura filosófica de Homero e Hesíodo, em âmbito pitagórico. Essa exegese pitagórica inaugura aquela que, somente depois, Platão e Aristóteles chamarão de theologia:

O trabalho de construção que pressupõe o diálogo entre Homero, Hesíodo e Pitágoras define-se fundamentalmente, como vimos, no plano do pensamento religioso. [...] É essencialmente uma "teologia" aquela que os poemas de Homero e Hesíodo representam para os gregos e, em particular, para os pitagóricos (Detienne 1962: 95). ${ }^{104}$

${ }^{101}$ Orig.: "Philolaus deserves a prominent place in the history of Greek philosophy as the first thinker self-consciously and thematically to employ mathematical ideas to solve philosophical problems".

${ }^{102}$ Ver-se-á com mais detalhes esta polêmica no capítulo quarto.

${ }^{103}$ Para a síntese madura da abordagem antropológica e comparativista ao mundo antigo de Detienne, veja-se especialmente seu mais recente Comparer l'incomparable (2000).

${ }^{104}$ Orig.: "Le travail de construction que suppose le dialogue entre Homère, Hésiode e Pythagore s'est defini de plus em plus, nous l'avons vu, sur le plan de la pensée religieuse. [...] C'est essentiellement une 'théologie' que les poèmes d'Homère et d'Hésiode représentent pour les Grecs et, en particulier, pour les Pythagoriciens”. A tese fundamental desta obra de Detienne está baseada no testemunho de Neantes, cf. referido por Porfírio (VP: 1), de uma formação inicial de Pitágoras no âmbito da poesia homérica: Pitágoras teria sido discípulo de Hermodamante, 
A tese da leitura teológica dos poetas arcaicos entre os pitagóricos é recuperada por Detienne em relação aos estudos sobre a interpretação demonológica dos versos de Os trabalhos e os dias, de Hesíodo: sobre a noção de daimon no pitagorismo antigo, Detienne (1963) dedica uma obra inteira, que, em linha com a obra imediatamente precedente, considera que o pitagorismo tenha estabilizado o conceito de daimon, até então extremamente vago, para indicar com ele a intermediação entre homens e deuses. Na exegese pitagórica, portanto, o conceito adquire uma consistência teológico-filosófica que não possuía anteriormente. ${ }^{105}$ Os sucessivos estudos de Detienne, dedicados às prescrições dietéticas dos pitagóricos $(1970 ; 1972)$, seguem a mesma linha teórica de considerá-las fundamentalmente uma expressão de sua compreensão da relação com os deuses, em sentido teológico:

O sistema de alimentação determinado pelas principais práticas alimentares dos pitagóricos aparece assim como uma linguagem por meio da qual este grupo social traduz suas orientações e revela suas contradições (1970: 162). ${ }^{106}$

Fundamentada na recusa em provocar a morte do animal para o sacrifício, a ritualidade da alimentação pitagórica procura instaurar uma comensalidade com os deuses, que, dessa forma, elimina a separação clara dos alimentos divinos e humanos que subjaz ao sacrifício olímpico tradicional, operando uma inversão na antropologia teológica:

De um sacrifício para outro, não somente as oferendas mudam de natureza, mas os modos da relação com os deuses se invertem. A inversão é marcada em especial no caso do estatuto religioso dos cereais. No sacrifício olímpico, são os grãos de trigo e cevada (inteiros) (oulochutai), a serem espargidos sobre as vítimas animais, representando a alimentação especificamente humana, reservada aos mortais que cultivam a terra e comem o pão (1970: 152). ${ }^{107}$

que pertencia a uma família tradicional de rapsodos homéricos, os Creofiléus. Isso permite a Detienne afirmar que Samos seria o lugar do primeiro encontro entre poesia e filosofia. Para uma crítica a esse pressuposto e à sucessiva argumentação de Detienne, cf. Feldman (1963: 16) e Pollard (1964: 188).

${ }^{105}$ A obra foi precedida por pelo menos dois artigos em que o autor inaugurava a pesquisa e definia suas linhas fundamentais (Detienne 1959a e 1959b). Para uma crítica à leitura de Detienne, cf. Kerferd (1965), que observa como o conceito de daimon seja, com toda probabilidade, uma atribuição platônica ao pitagorismo antigo (1965: 78), não permitindo, dessa maneira, sustentar a tese da original conceituação teológica em âmbito protopitagórico. Uma recepção mais calorosa, ainda que reclamando de certa audácia na questão das fontes, lhe é reservada por Vidal-Naquet (1964).

106 Orig.: "Le systeme des nourritures fernie par les principales pratiques alimentaircs des Pythagoriciens apparait done comme un langage a travers le quel ce groupe social traduit ses orientations et revele ses contradictions".

${ }^{107}$ Orig.: "D'un sacrifice a l'autre, non seulement les offrandes changent de nature, mais le mode de relation avec les dieux s'inverse. Le renversement se marque en particulier dans le statut religieux des céréales. Dans le sacrifice olympien, les grains d'orge et de ble (entiers) (oulochutai), que les sacrifiants répandent sur les victimes animales, represéntent le nourriture spécifiquement 
Longe das tentativas teologizantes das expressões da religião pitagórica operadas por Detienne, seguem os estudos de grandes historiadores e arqueólogos da religião antiga. Entre eles: Cumont (1942a;1942b) e Carcopino (1927; 1956) dedicam-se à recepção das tradições pitagóricas no interior do simbolismo funerário romano; diversos artigos de Festugière, muitos deles recolhidos finalmente nos Études de religion grecque e hellenistique (1972), e as duas importantes obras de Lévy $(1926 ; 1927)$ sobre a lenda de Pitágoras. Todos eles reconhecem, na recepção de motivos pitagóricos no interior das expressões da religiosidade helenística orientalizante, uma continuidade entre pitagorismo antigo e pitagorismo tardio, no que diz respeito às questões religiosas; tanto de fazer pensar em uma espécie de rio subterrâneo de tradições religiosas atribuídas ao pitagorismo que flui ao longo de mais de mil anos (Burkert 1972: 6). ${ }^{108}$

Um capítulo especial dessa relação do pitagorismo com o mundo religioso é certamente aquele das relações perigosas do pitagorismo com o mundo de ritos e mitos que se convencionou reunir debaixo da definição orfismo. A conexão do pitagorismo com o orfismo, para além de estéreis petitiones principii presentistas, que reclamam uma suposta separação entre filosofia e misticismo, é ligada provavelmente a temáticas e experiências específicas, como aquelas relativas à teoria da imortalidade da alma, de maneira especial à metempsicose ou à cosmologia. A segunda metade do século XX marca a descoberta de novos documentos órficos. Uma descoberta que, a bem da verdade, nunca parou desde a edição moderna dos fragmentos de Kern (1922): entre eles, especialmente as lâminas de ouro (Zuntz 1971; Pugliese Carratelli 2001) e novos papiros, especialmente o papiro Derveni, datado do século IV a.C, que contém uma exegese alegórica de um mais antigo poema cosmogônico. ${ }^{109} \mathrm{De}$

humaine, réservée aux mortels qui cultivent la terre et mangent le pain”. Da mesma forma, isto é, sublinhando o processo de racionalização teológica, Detienne interpretará as indicações dietéticas pitagóricas relativas ao uso de um tipo especial de alface, que eles chamavam de eunuco. Esta era especialmente indicada para o período estival, pois suas propriedades diminuíam o desejo sexual, considerado pernicioso à saúde na referida estação, por causa da debilitação provocada pelo forte calor. Evidencia-se aqui um uso dos mitos, neste caso do grupo de mitos relativos aos jardins de Adonis, para fins ético-teológicos (Detienne 1972: 125-130).

${ }^{108}$ De grande interesse histórico, além de inequívoco sinal da erudição e do amplo raio de investigação à qual Lévy dedicava-se, é a coleção póstuma de suas Recherches esséniennes et pythagoriciennes (1965): uma série de ensaios em que o autor dedica-se a desvendar possíveis influências não-judias e, notadamente, pitagóricas, no movimento religioso judaico dos essênios, tido como depositário da célebre biblioteca de Qumram, próximo ao Mar Morto.

${ }^{109} \mathrm{Cf}$., para a primeira edição oficial do papiro, Kouremenos, Parássoglou e Tsantsanoglou (Derveni Papyrus, 2006). Para um estudo mais aprofundado do papiro, cf. as atas de um recente colóquio realizado em Princeton (Laks e Most 1997). Um grupo de estudiosos liderado por Pierris e Obbink, com a ajuda da moderna tecnologia de imagem multispectral a raios infravermelhos, em colaboração com a Brigham Young University, está empenhado em um estabelecimento paralelo do texto. Para os impactos da descoberta para o estudo do orfismo pré-platônico, cf. especialmente Burkert (1982; 2005), Kingsley (1995), Betegh (2004), Tortorelli Ghidini (2000; 2006), Bernabé (2002; 2007a). Entre outros papiros recentemente descobertos, vejam-se especialmente o Papiro de Bologna e diversos papiros mágicos gregos. Para uma resenha 
especial relevância, pela sobriedade e o cuidado filológico, é o estudo dedicado às relações entre orfismo e pitagorismo por Bernabé (2004), assim como as mais recentes observações sobre o tema em Bernabé e Casadesús (2009).

O'revival' de estudos que seguiu as descobertas relacionadas anteriormente confirma, em geral, a profunda relação do orfismo com o dionisismo e o pitagorismo. Pugliese Carratelli $(2001,18)$ propõe uma solução para a eterna questão das modalidades dessas interpenetrações, identificando "um particular caráter conferido ao genuíno orfismo por uma íntima conexão deste com a escola pitagórica". Substancialmente baseado na análise original das lâminas de ouro órficas, a tese de Pugliese Carratelli é de que teria havido uma mescla teórica entre os dois movimentos naquela que pode ser considerada uma reforma do orfismo, operada pelos pitagóricos da primeira hora, provavelmente já nos séculos VI e V a.C. Surgiria assim uma nova "filosofia da imortalidade", de maneira distinta de um grupo de lâminas contendo fórmulas para práticas rituais e invocações às divindades ctônicas (entre elas Perséfone, Dioniso Zagreu e Hades) ou viáticos para enfrentar as terríveis provações pelas quais o iniciado deve passar (desse grupo fazem parte lâminas como a de Thurii, Pelinna, Eleutherna, Pherai). Um segundo grupo, resultado dessa reforma pitagórica mencionada há pouco, enfatiza, ao contrário, as temáticas de um empenho ético e espiritual, por sua vez intimamente ligado ao exercício intelectual de compreender, com o auxílio de Mnemosýne, os princípios cósmicos e do viver humano. Uma imortalidade que passaria pelo exercício da memória e pela sabedoria que dela deriva, portanto. A prova disso, para além desta dimensão científica da memória, é que não há dúvidas de que a mnemê seja um dos elementos fundamentais do estilo de vida pitagórico: a tradição é unânime em recordar que o membro da koinonía pitagórica era instruído a dedicar um período específico do dia (de manhã ou de noite) para a anamnésis, a recollectio, de todos os eventos do dia anterior (Iambl. VP: 165). Uma provável consequência da imbricação dos dois movimentos é o fato de tanto Heródoto quanto Platão revelarem forte tendência a confundi-los, sinal da dificuldade - de certa maneira e sob certos pontos de vista doutrinários e sociais - de distingui-los. ${ }^{110}$

Com essa referência ao orfismo, conclui-se este panorama da história da crítica, que, conforme anunciado no próprio título da presente seção, é ocupado pelos recentes trabalhos de Kingsley. De fato, a obra de Kingsley constitui o ponto de fuga, não somente desta linha de interpretação do pitagorismo como movimento intelectual profundamente marcado pelas relações com o mundo religioso de seu tempo, mas também de grande parte das questões centrais até aqui levantadas em relação à história da crítica do pitagorismo. Há nele uma perspectiva de solução da maioria dessas questões, que se apresenta de forma bastante incomum. Kingsley dedica-se a uma releitura, conscientemente original e polêmica, dos pressupostos subjacentes à crítica das tradições dos

das descobertas de novos fragmentos órficos após a segunda guerra mundial, cf. Bernabé (2000).

${ }^{110}$ Cf. Heródoto (II, 81); Para Platão, além do Fédon, cf. Górgias (492e), Crátilo (400c), Fedro (62b, 67c-d, 81e, 92a) e Mênon (81a). A questão será retomada em detalhe no capítulo terceiro. 
filósofos da Magna Grécia: tanto a primeira monografia, dedicada ao pitagórico Empédocles (1995), quanto as duas seguintes, dedicadas ao também pitagórico Parmênides (1999; 2003), representam uma "radical inversão hermenêutica" no interior do panorama dos comentadores (Gemelli 2006: 657).

Kingsley é devedor, ao mesmo tempo, de três das mais significativas contribuições hermenêuticas do século XX: de um lado do ceticismo de Cherniss (1935), em relação ao valor a ser dado ao testemunho aristotélico; de outro, da tradição - de autores como Detienne e Festugière - da inserção da filosofia em seu nascer no interior das tradições religiosas de seu tempo. Em terceiro lugar, possuem uma influência decisiva os estudos orientalistas aplicados às noções fundamentais da filosofia antiga. ${ }^{111}$

A articulação dessas importantes tradições, somada a uma ampla competência tanto histórico-arqueológica como de antropologia da religião, por sua vez acompanhada por um dever de casa filológico francamente cuidadoso, permite a Kingsley enveredar por um caminho extremamente ousado de resolução do obstáculo da doxografia de matriz aristotélica. A novidade de sua obra (ainda que não totalmente original em cada uma de suas partes, sem dúvida original na articulação consciente delas) encontra-se na utilização de outros textos, alternativos aos normais, fundamentalmente advindos tanto da tradição árabe da filosofia antiga quanto da literatura alquimística e hermética. A eles, acrescenta-se a proposta de uma renovada confiança nos escritos da tradição neopitagórica e neoplatônica. ${ }^{112}$ As conclusões às quais Kingsley declara chegar pretendem mudar radicalmente o eixo da pesquisa sobre os pré-socráticos em geral, e sobre o pitagorismo de maneira especial, de duas formas.

De um lado, recolocando metodologicamente em questão a abordagem historiográfica normal da filosofia pré-socrática, oferecendo instrumentos e perspectivas inéditas, muitas delas ainda a serem exploradas. É certamente o caso da afirmação pela qual, naquilo que é considerado comumente como perversão mágico-teúrgica da filosofia racional nas fontes neopitagóricas, ao contrário

111 Veja-se como exemplo dessa marca orientalista na lectio de Kingsley, sua resenha, extremamente crítica, à monografia de Huffman (1993) sobre Filolau e sua tese sobre a perspectiva epistemológica deste (Kingsley 1994).É também significativo, nesse sentido, o fato de Kingsley ter sido orientado em seu doutorado em Oxford por Martin West (Stroumsa 1997: 212).

112 É o caso de sublinhar que a recente descoberta de diversos versos atribuídos a Empédocles, no célebre Papiro de Strasburgo (Martin e Primavesi 1998), que teve lugar na cidade egípcia de Akhmîn, parece confirmar a tese central de Kingsley, pela qual haveria uma circulação independente dos textos pré-socráticos em âmbito alquimístico: é certamente o caso da tradição que é remetida a Zósimo de Panópolis (isto é, da cidade de Akhmîn), gnóstico de âmbito alquimístico, e à importante obra alquimística Turba Philosophorum, que viu sua luz na mesma cidade. Ambas as tradições referem-se, de forma independente da tradição doxográfica normal, a Empédocles e à tradição pitagórica (Kingsley 1995: 56-67). Cf. também Nucci (1999). Para a mais recente coleção da obra de Zosimo, cf. o volume de Mertens (1995) de Les alchimistes grecs. Para uma recente discussão das relações entre alquimia e filosofia antiga, cf. Viano (2005). 
Os pitagóricos posteriores permaneceram fiéis ao impulso inicial do pitagorismo. [...] Historicamente, como é natural, a importância do consenso entre o pitagorismo mais antigo e aquele mais tardio é sublinhada ainda pelas evidências, já citadas, de que tradições pitagóricas e a estas relacionadas passaram diretamente do Sul da Itália e da Sicília para o Egito helenístico (Kingsley 1995: 339). ${ }^{113}$

\section{Isto é, sem passar por Platão e Aristóteles. ${ }^{114}$ \\ De outro lado, como bem viu Gemelli, Kingsley opera}

Um questionamento não somente dos critérios interpretativos comumente utilizados para enfrentar estes textos, do enorme peso atribuído à força tranquilizadora da "racionalidade", da própria concepção de filosofia como exercício intelectual, mas também, e sobretudo, do éthos polýpeiron que guia nossa vida (Gemelli 2006: 670-671). ${ }^{115}$

Em sintonia com uma compreensão da filosofia antiga que procuraria fundamentalmente alcançar certo tipo de bios, isto é, pensada antes de tudo como exercício a serviço de uma vida melhor, Kingsley recoloca não somente a filosofia pitagórica, mas também a história da crítica a esta, nos trilhos de uma sabedoria que, articulando mistérios e magia, cura e dietética, contribui de fato para uma vida melhor. ${ }^{116}$ Não por acaso, de forma francamente pouco ritual, o mesmo Kingsley apresenta assim o objetivo de sua monografia sobre Parmênides e os lugares obscuros da sabedoria: "E o que é aquilo que desejamos? É disso que esta história trata” (1999: 4). ${ }^{117} \mathrm{E}$, logo em seguida, busca introduzir de forma existencial sua releitura mística dos dois caminhos de Parmênides: "se tiver sorte, em algum momento de sua vida, você chegará a um ponto completamente sem saída" (1999: 5). ${ }^{118}$ Um estilo de escrita, esta de Kingsley, que corresponde a um estilo de historiografia que sai decididamente das regras tácitas da aceitabilidade acadêmica e coloca-se em lugar alternativo e marginal, que o próprio autor parece cavar para si mesmo com uma satisfação que não faz questão de esconder. ${ }^{119}$

${ }^{113}$ Orig.:"The later Pythagoreans were simply remaining true to the inicial impetus of Pythagoreanism. [...] Historically, of course, the significance of the accord between early and later Pythagoreanism is further underlined by the evidence already considered of Pythagorean and related traditions passing directly from southern Italy and Sicily into Hellenistic Egypt".

${ }^{114}$ Para mais ampla resenha dessa questão, cf. Cornelli (2002; 2003a).

115 Orig.: "una messa in discussione non solo dei criteri interpretativi comunemente adottati per affrontare questi testi, dell'enorme peso attribuito alla forza tranquillizzante della 'razionalità', della concezione stessa di filosofia come esercizio intellettuale, ma anche e soprattuto dell' éthos polýpeiron che guida la nostra vita”.

${ }^{116} \mathrm{Cf}$. nesta mesma linha a síntese que faz Hadot (1999), ainda que manualística, da filosofia pensada em suas origens como fundamentalmente um estilo de vida.

${ }^{117}$ A referência dos lugares obscuros da sabedoria é ao titulo da obra de Kingsley (1999): "In the dark places of wisdom". Orig.: "And what is it that we long for? That's what this story is about".

${ }^{118}$ Orig.: "If you're lucky, at some point in your life, you'll come to a complete dead end".

119 É certamente este o caso de sua monografia mais recente (Kingsley 2010) sobre 
Obviamente, a proposta de Kingsley encontra diversas resistências e dificuldades. Algumas internas ao próprio sistema argumentativo do autor, como a de dar conta, de maneira adequada, da articulação de testemunhos tão tardios e tão diferenciados entre si para elaborar uma visão da filosofia pré-socrática e do pitagorismo de maneira especial, de certa forma coerente, ao menos do ponto de vista historiográfico. É preciso concordar com Morgan (1997: 1130) que, de vez em quando, "ele não junta as peças" ('he does not tie the pieces together'), e não fica clara qual seria com precisão a configuração histórica do protopitagorismo, tanto do ponto de vista social quanto doutrinário, para além de vaga referência à magia, aos mistérios e à cura. Outras resistências são levantadas por comentadores que não compartilham da confiança no novo caminho metodológico indicado por Kingsley. ${ }^{120}$ Provavelmente, os próximos anos irão mostrar se o caminho por ele revelado terá mais seguidores ou menos. ${ }^{121}$

Pitágoras, que pretende trazer uma nova evidência documental, dramática e revolucionária, ao dizer do próprio autor. Notadamente relativa à conexão de Pitágoras com a figura de Abáris, o sacerdote de Apolo Hiperbóreo, que chega na Grécia com toda probabilidade do altiplano mongólico, do Tibete, como o próprio deus, como purificador e entrega exatamente a Pitágoras sua flecha mágica. Ainda que, como é usual, repleta de notas e referências bibliográficas de amplo raio, a obra de Kinsgley mantém um ritmo e um estilo bastante distantes da calma e sóbria argumentação histórico-filológica. Baste pensar no título da mesma: A Story Waiting to Pierce you: Mongolia, Tibet and the Destiny of the Western World.

${ }^{120}$ Para todos, cf. a seca resenha de O'Brien (1998).

${ }^{121}$ Tanto na mais recente monografia dedicada a Pitágoras (Riedweg 2002) como no capítulo sobre Pitágoras na edição dos Vorsokratiker pela Tusculum (Gemelli 2007b), Kinsgley começa a deixar sua marca hermenêutica. Não é certamente um acaso o fato de que ambos os autores sejam discípulos de Burkert. 


\subsection{Conclusão}

Entre circularidades hermenêuticas e pânicos historiográficos, a breve história da crítica moderna sobre o pitagorismo agora esboçada resultou em uma narrativa em que cada fato e cada testemunho foram colocados em discussão, gerando controvérsias e recíprocas refutações. A dúvida, já zelleriana, de que, no caso do pitagorismo, estaríamos diante de um intrincado tecido de tradições escassamente relevantes para uma séria história da filosofia acompanha sub-repticiamente grande parte das tentativas de interpretação do pitagorismo. Desde o historicismo evolucionista de Zeller, que influencia diretamente a coleção de Diels, passando pela abordagem apriorística de Burnet, que identifica o arcaico com o elemento religioso do pitagorismo, e o mais recente com aquele científico, a ponte que pretende separar os dois pitagorismos tornou-se o problema central da história da crítica do espinhoso problema da complexidade multifacetada do pitagorismo.

As primeiras reações ao ceticismo dos comentadores não demoraram a aparecer. Estudos de Rohde e Delatte levantaram os primeiros questionamentos relativos à pretensa verdade absoluta da equação entre fontes tardias e sua confiabilidade. As sucessivas intervenções hermenêuticas, a partir de Cornford e Guthrie, desenharam o caminho da composição da diversidade das tradições referidas ao pitagorimo. Criticando a falácia modernista, Cornford inverte a lógica presentista, indicando no lado místico do pitagorismo sua herança mais importante, não estando este em aberta inconsistência com a filosofia. Guthrie, de sua parte, propondo um método apriorístico, afirma a coerência interna do pitagorismo pré-platônico. A influência da escrita das grandes Histórias da Filosofia do século XX contribuiu certamente para estabelecer essa busca unitarista. Ao mesmo tempo, todavia, surgiam obras dedicadas ao estudo de algumas áreas particulares e alguns problemas específicos da questão das fontes; in primis, a questão do envolvimento político das comunidades pitagóricas. Uma questão à qual diversos comentadores dedicaram-se, de maneira especial na tradição italiana destes estudos, desde a época romana, atravessando o Quattrocento renascentista, até a um renovado interesse pela questão em historiadores contemporâneos.

Em contrapartida, uma série de comentadores dedica-se ao estudo das fontes indiretas, tanto pré-socráticas quanto platônicas, do pitagorismo antigo. Ainda que a imagem de um diálogo pré-socrático entre o pitagorismo e outras escolas, apesar de tentadora, pareça carecer de bases textuais sólidas, a importância da tese de Tannery sobre as relações teoréticas entre eleatismo e pitagorismo inaugura uma área de pesquisa que começa a colocar em questão a presunção do testemunho único de Aristóteles, trazendo para a crítica outras fontes. $\mathrm{O}$ valor a ser dado tanto aos testemunhos de Platão quanto aos de Aristóteles está longe de ser um consenso. Posições mais ingênuas, do ponto de vista historiográfico, como as de Burnet e Taylor, alternaram-se a posições céticas como as de Cherniss e Frank. Enquanto o trabalho de Burkert pareceu 
significar uma verdadeira terceira-via da crítica entre o ceticismo zelleriano e uma excessiva confiança nas fontes, a gangorra hermenêutica em que se encontra parece pender mais para uma compreensão do pitagorismo originário como um movimento religioso.

Os estudos desse lado religioso do pitagorismo, a partir de Detienne e Cumont, marcam fortemente a história da crítica. Um locus privilegiado para esses é certamente aquele das relações com o orfismo: um revival de estudos sobre o tema seguiu-se à ampliação de seu corpo documental graças às recentes descobertas arqueológicas.

Enfim, a radical inversão hermenêutica, representada pela obra de Kingsley, encerrou o panorama da história da crítica moderna, demostrando ser o ponto de fuga de três das mais significativas contribuições hermenêuticas do século XX, isto é, do ceticismo em relação ao valor a ser dado ao testemunho aristotélico, da inserção da filosofia em seu nascer no interior das tradições religiosas de seu tempo, e da influência dos estudos orientalistas sobre a história da filosofia antiga. Kingsley oferece soluções relativamente originais e ousadas às questões sensíveis de crítica das fontes. Destaca-se especialmente a recolocação no centro do interesse da questão do bios e, nesse sentido, a proposta de uma continuidade maior que aquela geralmente admitida entre protopitagorismo e neopitagorismo, e, portanto, na própria história da tradição da filosofia pitagórica.

O breve panorama, aqui resumido por meio de seus motivos e autores principais, resulta em uma imagem poliédrica e bastante contraditória do pitagorismo. Emerge, assim, a questão central para a compreensão do pitagorismo: aquela de considerá-lo como categoria historiográfica, superando metodologicamente a pretensão de alcançar uma única compreensão. No lugar disso, conscientemente, será preciso percorrer os caminhos das diversas interpretações e dos diversos estratos da tradição, em busca de uma imagem suficientemente plural ao ponto de permitir compreender o pitagorismo na diversidade em que ainda se apresenta à interpretação atual.

É o que se ensaiará nos capítulos a seguir. 


\section{PARTe II}

O PITAGORISMO COMO CATEGORIA HISTORIOGRÁFICA 


\subsection{INTERPRETAR INTER PRETAÇÕES: DIMENSÃO DIACRÔNICA E SINCRÔNICA}

No início do percurso da história da crítica sobre o pitagorismo, desenhado no capítulo anterior, destacou-se que Zeller já enfrentava o problema da categorização historiográfica do pitagorismo - por assim dizer - de peito, ao se perguntar se, no emaranhado de fontes e tradições, haveria algo no pitagorismo que pudesse ser considerado como um sistema propriamente filosófico e científico (Zeller e Mondolfo 1938: 597).

A suspeita zelleriana, compartilhada, conforme visto, por muitos comentadores que a ele se seguiram, introduz bem aquela que foi prenunciada na Introdução como a problemática central desta tese, isto é, de como deverá ser tratada a diversidade de doutrinas e experiências que a tradição reuniu debaixo do guarda-chuva histórico-teorético do pitagorismo. Em termos mais precisos, isso significa perguntar-se a que corresponderia exatamente essa categoria historiográfica que a tradição convencionou chamar de pitagorismo.

A descoberta do alcance histórico e teorético dessa categoria passa por duas dimensões-chave do problema: uma dimensão que se chamará diacrônica, outra que será identificada como sincrônica. Ainda que complementares, as duas dimensões desenham cada uma um campo de investigação distinto.

Descrever a categoria historiográfica pitagorismo em sua dimensão diacrônica implica seguir seu processo de construção através da história da tradição, desde Platão e Aristóteles até a literatura neoplatônica, em busca de formas e conteúdos que possam indicar continuidade e até mesmo possível homogeneidade.

Seu pressuposto é que, obviamente, não é possível alcançar em última análise um Pitágoras histórico, ou um pitagorismo das origens, pois essa tradição é virtualmente inexistente. Tratar-se-á, portanto, nas palavras de Burkert, de interpretar interpretações:

A primeira coisa a ser feita, uma vez que o fenômeno original não pode ser alcançado diretamente, é interpretar interpretações, identificar e destacar as diferentes camadas da tradição e procurar as causas que originaram uma transformação na imagem de Pitágoras (Burkert 1972: 11). ${ }^{1}$

O esforço da categorização diacrônica do pitagorismo será aquele de destrinchar os diferentes estratos da tradição. Tarefa esta, a bem da verdade, hoje francamente mais fácil do que era no tempo de Zeller, especialmente graças aos avanços dos estudos sobre a tradição acadêmica e peripatética. ${ }^{2}$

${ }^{1}$ Orig.: "The first task must be, since the original phenomenon cannot be grasped directly, to interpret interpretations, to single out and identify the different strata of the tradition and to look for the causes that brought transformation to the picture of Pythagoras".

${ }^{2}$ A partir das demonstrações de Jaeger (1934) da existência de projeções sobre o pitagorismo, tanto acadêmicas como peripatéticas, de seus próprios ideais; assim como dos estudos de Wehrli (1944-1960) sobre Dicearco (1944), Aristóxeno (1945), Clearco (1948), Heráclides (1953) 
Não será objetivo deste esforço de categorização do pitagorismo tentar reduzir sua característica básica de um movimento filosófico extremamente controvertido (Huffman 2008a: 225). Ao contrário, a proposta é mais propriamente aquela de compreender como, na imbricação das dimensões diacrônicas e sincrônicas, a categoria pitagorismo tem sobrevivido à previsível diluição de um movimento não somente radicalmente multifacetado e extensivamente diverso em seus autores e temáticas, mas que, além disso, atravessa diacronicamente mais de mil anos de história do pensamento ocidental. Assim, o desafio da pesquisa e sua originalidade no interior das normais problemáticas da história da filosofia pré-socrática residem no fato de o pitagorismo não ter propriamente nunca morrido, o que torna ainda mais complicado o trabalho de articulação das notícias advindas da tradição. Para o arqueólogo do pensamento filosófico antigo, como uma cidade que permaneceu continuamente habitada, o pitagorismo apresenta, de fato, uma especial dificuldade.

De maneira muito mais complicada do que um lugar destruído por uma única catástrofe e, em seguida, abandonado, a dificuldade especial no estudo do pitagorismo vem do fato de que ele nunca morreu como, por exemplo, o sistema de Anaxágoras ou até mesmo aquele de Parmênides (Burkert 1972: 10). ${ }^{3}$

Para que o caminho através das tradições sobre o pitagorismo seja de fato percorrível, apresenta-se a necessidade de desenhar um percurso metodológico original - uma régua de Lesbos, de aristotélica memória - que se adeque à natureza do objeto a ser pesquisado:

O que a natureza da situação requer é um tratamento do problema tanto multifacetado quanto for possível. Pois muitas das conclusões contraditórias resultaram da investigação e do rastreamento do curso de caminhos únicos de desenvolvimento, sem alguma ideia da forma em que estes mesmos pudessem convergir com outras linhas igualmente importantes (Burkert 1972: 12). ${ }^{4}$

O comentador encontra-se na frente de uma bifurcação que o obriga a uma opção metodológica, isto é, ou o pitagorismo será compreendido como uma multifacetada e complexa categoria historiográfica, a ser desenhada acompanhando tanto o longo percurso da história da tradição como a relação

e Eudemo (1955). Não devem ser também esquecidas as fundamentais contribuições para a compreensão da relação entre platonismo e pitagorismo que advêm dos trabalhos da assim chamada escola de Tübingen-Milão sobre a doutrina dos princípios em Platão e na Academia Antiga: cf., para isso, Krämer (1959), Gaiser (1963), Szlezák (1985), Reale (1991).

${ }^{3}$ Orig.: "far more complicated problems than a site destroyed by a single catastrophe and then abandoned, the special difficulty in the study of Pythagoreanism comes from the fact that it was never so dead as, for example, the system of Anaxagoras or even that of Parmenides".

${ }^{4}$ Orig.: "What the nature of the situation demands is a many-sided treatment of the problem as is possible. For many of the contradictory conclusions have come from investigating and tracing the course of single paths of development, with no thought of the way in which these may converge with other, equally important lines". 
desta com o mundo intelectual da filosofia que nasce entre os séculos VI e V a.C, ou não será compreendido "tout court".

Uma consequência disso é que a abordagem deverá ser necessariamente interdisciplinar: a normal (ainda que discutível) divisão do trabalho nos estudos clássicos, entre historiadores, arqueólogos, filólogos e filósofos, não parece funcionar muito bem no caso do pitagorismo:

Pode acontecer que o historiador da ciência tenha feito sua reconstrução sobre fundamentos filologicamente inadequados; que o filólogo assuma o resultado aparentemente exato do historiador da ciência; que o filósofo, partindo deste critério, rejeite evidências contraditórias - e assim por diante (Burkert 1972: 12).5

Ver-se-á, em muitos casos, a seguir, a importância de uma articulação das informações arqueológicas e da abordagem antropológica, de um lado, com a análise filológica, do outro: será este certamente o caso do problema das relações entre orfismo e pitagorismo na Magna Grécia dos séculos VI e V a.C; ou da necessária articulação da história da filosofia com a história da ciência antiga, que é especialmente importante para a resolução da pretensa crise dos lógoi incomensuráveis ou irracionais.

Uma polymathia metodológica (pace Heráclito) será, portanto, o caminho adequado para que a categoria historiográfica do pitagorismo possa emergir das névoas, tanto de uma complexa história da tradição, como da identificação do que seria filosofia em suas origens. ${ }^{6}$

Esta última identificação introduz a segunda dimensão do pitagorismo, a dimensão sincrônica. Compreender sincronicamente o pitagorismo significará fazê-lo caber no interior das categorias pelas quais normalmente descrevemos a filosofia antiga, e a filosofia pré-socrática de maneira especial. Categorias como pré-socrático, escola, ciência, religião, política, ou até mesmo filosofia (quando distinta de outras atividades intelectuais e literárias) são comumente utilizadas para compreender o lugar do pitagorismo em suas origens. Nenhuma dessas categorias normais será obviamente aplicável "tout court" ao pitagorismo. Ao contrário, ainda que nos limites do objeto aqui desenvolvido, a presente investigação pretende apontar para a necessidade de ajustes na mesma abordagem metodológica à filosofia pré-socrática normalmente em uso, com consequências facilmente aplicáveis, portanto, para além do estreito âmbito dos estudos sobre o pitagorismo antigo. $\mathrm{Na}$ linha do que se propõe, por exemplo, Gemelli, que, na introdução à nova edição dos Vorsokratiker (2007b) afirma:

A partir do momento em que se colocam os problemas fora do rígido esquema historicista do necessário progresso do pensamento filosófico e se observam os

${ }^{5}$ Orig.: "It can happen that the historian of science builds his reconstruction on a philologically inadequate foundation; the philologist takes over the seemingly exact result of the historian of science; the philosopher, on the basis of this criterion, rejects contradictory evidence-and so on".

${ }^{6}$ Heráclito parece criticar a $\pi 0 \lambda u \mu \alpha \theta i ́ n$ de Pitágoras em seus fragmentos 40 e 129 (22 B 40, 129 DK). 
textos na perspectiva de sua própria tipologia e do contexto pragmático em que foram concebidos, estes adquirem valores e significados bem mais complexos do que aqueles da simples "filosofia natural" (Gemelli 2007b: 440). ${ }^{7}$

No caso do pitagorismo, será necessário superar as rígidas dicotomias de uma historiografia demasiadamente acostumada a distinguir, por exemplo, entre ciência e magia, escrita e oralidade, jônicos e itálicos. Pois nenhuma destas, sozinha, parecerá dar conta da complexidade com que se apresentam as linhas fundamentais da organização social e da doutrina pitagóricas.

Ambas as dimensões, tanto a sincrônica como a diacrônica, aparecerão fortemente imbricadas ao longo da monografia, operacionalizando a definição de uma categoria historiográfica, aquela do pitagorismo, que compreenda a amplidão e a pluralidade da tradição em uma imagem que resulte quanto mais possível coerente.

Antes mesmo de adentrar, no capítulo terceiro e no quarto, nas duas questões fundamentais que contribuíram mais decididamente para a definição da categoria historiográfica do pitagorismo, será importante verificarmos aquele que pode ser considerado o ponto de partida, a questão vestibular para a historiografia do pitagorismo: a pergunta sobre quem poderia chamar a si mesmo de pitagórico.

\footnotetext{
${ }^{7}$ Orig.: "Sobald man die Probleme also ausserhalb des starren historistischen Entwurfs von der unabdingbaren Entwicklung des philosophischen Denkens angeht um die Text unter dem Blickwinkel ihrer Typologie sowie des pragmatischen Kontextes, in dem sie abgefasst worden sind, betrachtet, gewinnen sie Bedeutungen und Sinngehalte, die weit komplexer sind als die einfache "Naturphilolophie".
} 


\subsection{IDENTIDADE PITAGóRICA}

A definição da categoria pitagorismo não pode senão começar de uma pergunta que somente na primeira impressão pode parecer simples, mas que, em verdade, se demonstrará de difícil solução: quem pode ser definido como pitagórico no mundo antigo?

Muitos autores, a partir de Aristóteles, tentaram responder a essa pergunta procurando um critério temático que permitisse identificar certa unidade doutrinária. É certamente este o caso, há pouco citado, do privilégio concedido por Zeller exatamente à lectio aristotélica sobre os pitagóricos: privilégio este que se tornou, ao longo da história da crítica moderna, um consenso quase indiscutível: pitagórico é alguém que fala de números.

Este critério identitário resistiu majoritariamente até o divisor de águas representado pelo artigo de Zhmud (1989), que revela quanto de circular há na utilização do critério dos números para identificar um pitagórico:

$\mathrm{Na}$ grande maioria dos trabalhos sobre o pitagorismo, este problema não é sequer abertamente considerado, e um critério doutrinário é implicitamente usado como o principal método de trabalho. Um pitagórico é alguém que fala sobre o número. Estamos aqui na frente de uma óbvia petitio principii: pois aquilo que necessita ele próprio de uma prova é tomado como uma premissa inicial (Zhmud 1989: 272). ${ }^{8}$

Zhmud volta, com ainda mais força, nessa recusa de um critério doutrinário em sua monografia de 1997, ao ponto de Centrone (1999) observar que a tese deste autor coloca um ponto final na questão, não sendo mais possível identificar um pitagórico pela adesão a uma doutrina:

Uma das teses centrais desta monografia (Zhmud 1997), isto é, a ideia pela qual o critério de identificação de um pitagórico não seria a profissão de uma doutrina filosófica, encontra aqui uma base sólida e bem argumentada, e não penso possa ser colocada novamente em discussão (Centrone 1999; 424). ${ }^{9}$

Por outro lado, a história da filosofia acostumou-se a utilizar um critério geográfico, ao menos desde Diógenes Laércio (D. L. Vitae I. 13-15) para identificar, entre outras escolas filosóficas, aquela itálica ou pitagórica. Depois do fundador, o restante dos pitagóricos é elencado não tanto seguindo um

${ }^{8}$ Orig.: "in the overwhelming majority of works on Pythagoreanism this problem is not raised openly, and a doctrinal criterion is implicitly used as the main working method. A Pythagorean is one who speaks about Number. Here we are faced with an obvious petitio principii: that which itself is in need of being proved is taken as a starting premise".

9 Orig.: "Una delle tesi centrali di questa monografia (Zhmud 1997), e cioè l'idea che il criterio di individuazione di un pitagorico non consista nella professione di una dottrina filosofica, trova qui un fondamento solido e ben argomentato, e non penso possa più essere rimessa in discussione". Cf. também Centrone (2000: 145). Nesse ensaio, Centrone retoma os mesmos argumentos para tratar do que significa ser pitagórico na época imperial. 
estrito critério doutrinário (como é o caso de Empédocles ou Eudoxo, ou mesmo de Demócrito, cf. D. L. Vitae IX), mas por uma relação pedagógica direta, algum tipo de dependência intelectual de Pitágoras ou outro célebre pitagórico. No caso específico e único do pitagorismo, pela primeira vez, um grupo de filósofos é identificado não a partir de sua coerência doutrinária (physikoi), ou proximidade geográfica (eleatas), mas, sim, a partir do nome de seu fundador: pythagoreioi. ${ }^{10}$

Se o que faz alguém pitagórico não é a adesão a uma doutrina, sê-lo-á, então, a adesão a outra grande dimensão que a tradição aponta como essencial para a identificação de um pitagórico, isto é, a do bios, de determinado estilo de vida, expresso por akouismata e sýmbola, isto é, preceitos ouvidos e sinais de reconhecimento.

Parece ser este o caso do longo catálogo de pitagóricos que Jâmblico insere no final de sua Vida (Iambl. VP: 267) e que, com toda probabilidade, é de origem aristoxênica. ${ }^{11}$ Trata-se de uma longa sequência de 218 nomes, ordenados por um critério geográfico. Destes, a maioria, 34, são tarentinos, como o próprio Aristóxeno.

Entre todos os pitagóricos muitos ficaram anônimos e desconhecidos, de outros ao contrário conhecemos os nomes. De Crotona: Ipostratos, Dimantes, Égon, Émon, Cleóstenes, Ágela, Episilo, Ficiada, Écfanto, Timeu, Butão, Érato, Itaneu, Rodipo, Briantes, Evandro, Milias, Antimedontes, Agea, Leofrontes, Ágilo, Onata, Ipóstenes, Cleofontes, Alcmeão, Dámocles, Milon, Mênon.

De Metaponto: Brontino, Parmisco, [...] De Eleia: Parmênides. De Tarento: Filolau, Eurito, Arquitas, Teodoro, [...]. As mulheres pitagóricas mais conhecidas são: Tímica, mulher de Milias, Filtides, filha de Teofrio de Crotona e irmã de Bindaco, Ocelo e Ecelo, irmãos de Ocelo e Ocilio de Lucânia, Quilónides, filha de Quilon de Esparta, Cratesicleia de Lacônia, esposa de Cleánoros de Esparta, Teano [...] (Iambl VP: 267).

É significativo notar que, em seu formato de classificação com base geográfica, o catálogo pode ser aproximado ao modelo da tradição epigráfica antiga grega; ao contrário, o estilo de classificação mais em uso na literatura é

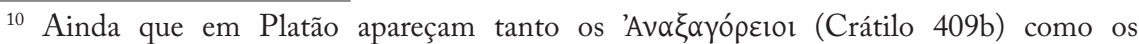

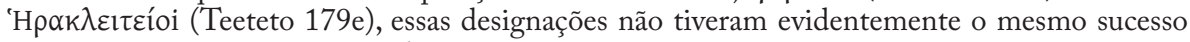
histórico daquela dos ПuӨ $ү$ үo cf. Minar (1942: 21-22).

${ }^{11}$ Com essa identificação concorda a maioria dos comentadores, a partir de Rohde (1872). Como ele também Delatte (1922: 182), Zhmud (1988: 273), Centrone (1996: 11), Giangiulio (Pitagora 2000: II 545) e Brisson e Segonds (Jamblique 1996). Burkert (1972:105 n40) afirma: "the only possible candidate for authorship seems to be Aristoxenus himself, working in the documentary method of the earliest Peripatos". Já Huffman (2008c) levantou recentemente algumas dúvidas em relação a esta atribuição, que o levam a uma conclusão cautelosa: "is does seem most plausible to assume that Aristoxenus is responsible for the core of catalogue, but it is important to recognize both that the arguments for Aristoxenus's authorship are not ironclad and that, even if the core is assigned to Aristoxenus, this does not mean that the catalogue has not undergone modifications" (Huffman 2008c: 297). 
construído com base nas relações familiares ou de discipulado, resultando na imagem de uma árvore genealógica. Um exemplo disso é Diógenes Laércio e mesmo no capítulo imediatamente anterior da própria Vida de Jâmblico (Iambl. VP: 266). Essa particularidade, com a inclusão de 17 mulheres e o desconhecimento de qualquer nome sucessivo ao século IV a.C e de grande parte dos apócrifos da literatura pseudopitagórica helenística (Thesleff 1965), tornam o catálogo um achado, com toda probabilidade muito antigo e extremamente valioso para o objetivo aqui declarado de procurar os critérios de identificação dos pitagóricos. ${ }^{12}$ De fato, não há aparentemente qualquer aproximação possível entre pitagóricos como Filolau, de um lado, e Apolônio, do outro, tanto do ponto de vista teorético-doutrinário, como das relações históricas entre eles ou de cada um com Pitágoras. O único critério plausível de sua identificação como pitagóricos torna-se o de uma adesão de cada um, antes que a alguma doutrina específica, a um estilo de vida, a um bios, que ambos reconhecem como pitagórico. Se é possível concordar com Huffman (1993: 11), quando fala de um estilo de vida que, todavia, "indubitavelmente devia incluir alguns princípios morais como a exortação a viver uma vida simples e a praticar a temperância”, esses princípios morais são tão genéricos ao ponto de, novamente, não poderem constituir propriamente um sinal de distinção do pitagórico com relação ao sophós antigo em geral. O próprio Hesíodo poderia, com toda probabilidade, compartilhá-los. ${ }^{13}$

É significativo o insucesso da recente tentativa de formulação, por parte de Huffman, de critérios que permitiriam identificar, no catálogo de Jâmblico - assim como para além dele -, determinado filósofo como pitagórico. Huffman (2008b, 299) postula três desses critérios: a) a existência de um testemunho indiscutível e antigo, isto é anterior ao século IV aEC, de que tal filósofo foi considerado pitagórico; b) evidência indiscutível de que tal filósofo tenha adotado o esquema metafísico básico dos pitagóricos, que Huffman faz coincidir com aquele descrito por Aristóteles e encontrado nos fragmentos de Filolau, e que a seu ver, corresponderia fundamentalmente com a doutrina "tudo pode ser conhecido através do número"; ${ }^{14} \mathrm{c}$ ) evidência de que a personagem está incorporada na tradição biográfica pitagórica, tendo sido discípulo ou interlocutor de algum pitagórico.

Ainda que o esforço de Huffman seja de fato original e louvável, seu resultado não permite chegar àquela "vigorosa" (vigorous) tradição pitagórica (2008c: 301) que o autor pretendia. Pois a resposta aos três critérios dependerá ainda e fortemente de uma pré-compreensão - esta sim, discutível - do que seja um testemunho indiscutivelmente antigo (a) ou de qual seja o pretenso esquema metafísico pitagórico (b). O próprio Huffman, ainda que não pelos

\footnotetext{
${ }^{12}$ Para uma coleção anotada dos escritos atribuídos a mulheres pitagóricas, fundamentalmente baseada em Thesleff (1965), vejas-e agora Montepaone (2011).

${ }_{13}$ Orig.: "indoubtely also included certain moral principles such as the exortation to live a simple life and to practice temperance".

${ }^{14}$ A mesma ideia estava já em Huffman (1993: 74). A questão receberá a atenção que certamente merece no capítulo quarto.
} 
mesmos motivos agora sugeridos, acaba reconhecendo que uma longa lista de pitagóricos ainda resulta da aplicação destes critérios "rigorosos". Contudo, essa não passaria de um

reflexo do fato que Pitágoras era famoso por ter deixado atrás dele um estilo de vida, de forma que, junto com pitagóricos de tendência cosmológica e metafísica, como é o caso de Filolau e Arquitas, existiu grande número de outras figuras que podem ser chamadas de pitagóricos simplesmente com base na maneira com que eles viviam suas vidas (Huffman 2008c: 301). ${ }^{15}$

Assim, novamente, o critério mais confiável, aquele do bios conforme transmitido pela tradição, exclui qualquer possibilidade de distinção com base nas doutrinas. É, portanto, o caso de concordar com Centrone quando conclui que:

O pitagorismo não surgiu como uma escola filosófica, e não pode ser uma doutrina filosófica o que permite identificar um pitagórico. Um critério mais confiável consistiria em considerar pitagóricos aqueles que a tradição antiga qualifica como discípulos ou sucessores de Pitágoras. [...] isso exclui a delimitação do fenômeno pitagórico a um âmbito específico bem preciso ou a uma filosofia monotemática (Centrone 1999: 441). ${ }^{16}$

Dessa forma, autores com interesses que vão da fisiologia à botânica, como é o caso de Alcmeão ou Menestor, podem ser considerados pitagóricos a todos os efeitos.

Porém, a adesão a um particular estilo de vida pressupõe, ao menos em seu momento inaugural pré-socrático, a existência real de uma comunidade que se estrutura a partir do mesmo estilo de vida. Mesmo depois, em idade helenística, quando a definição do bios poderá ser uma escolha individual, a comunidade dos inícios terá o sentido de um modelo distante no tempo a ser seguido. ${ }^{17}$ Contudo, que tipo de comunidade seria aquela da koinonía pitagórica?

Platão, na República, cita duas vezes nominalmente os pitagóricos: na primeira referência dá a entender que a comunidade compartilhava de um saber privado (idion):

15 Orig.: "reflexion of the fact that Pythagoras was famous for leaving behind him a way of life, so that in addition to Pythagoreans of a cosmological and metaphysical bent, such as Philolaus and Archytas, there were a number of other figures who can be called Pythagoreans merely on the basis of the way they lived their lives".

${ }_{16} \mathrm{Cf}$. também Zeller e Mondolfo (1938: 434). Orig.: "Il pitagorismo non è sorto come una scuola filosofica, e non può essere una dottrina filosofica ciò che permette di identificare un pitagorico. Un criterio più affidabile consiste nel considerare pitagorici coloro che la tradizione antica qualifica come discepoli o successori di Pitagora e aderenti all'associazione. [...] ciò esclude la delimitazione del fenomeno pitagorico a un ambito scientifico ben preciso o a una filosofia monotematica".

17 Para ampla discussão desta mudança da concepção do bíos em época helenísitica, cf. Vegetti (1989: 271-300). 
Mas então, senão na vida pública, ao menos naquela privada se diz que Homero, enquanto era vivo, tenha seguido pessoalmente a educação dos discípulos que amavam sua frequentação e que tenha transmitido às futuras gerações certo caminho de vida homérico, da mesma maneira que Pitágoras, que, por esse motivo, foi sobremaneira amado; e seus discípulos até hoje chamam pitagórico este estilo de vida, e por este parecem distinguir-se dos outros (Resp. X: 600ab).

O objeto desta paidéia pitagórica não seria tanto uma doutrina filosófica ou científica, e, sim, um trópos tồ bios, um estilo de vida. Em sentido contrário, todavia, na segunda referência ao tema, Platão parece querer identificar o pitagorismo com uma escola filosófica e de pesquisa:

É provável que, como os olhos são conformados pela astronomia, assim os ouvidos o sejam para o movimento harmônico, e que estas duas ciências sejam de alguma forma irmãs, como afirmam os pitagóricos, e também nós (Resp. VII: 530d).

A mesma ideia parece estar expressa na página seguinte da República, quando são opostos, de um lado aqueles que torturam as cordas e antepõem os ouvidos ao pensamento fazendo pesquisas musicológicas empíricas e, do outro, a pesquisa metódica dos pitagóricos (Resp. VII: $531 \mathrm{a}-\mathrm{d}) .^{18}$

Um fragmento de Arquitas, cuja autenticidade foi defendida recentemente por Huffman $(1985 ; 2005,112-114)$, apresenta a mesma ideia da irmandade entre astronomia e música:

Parece que os que se dedicaram às ciências matemáticas alcançaram bons resultados; e não é estranho que eles raciocinassem apropriadamente sobre cada coisa, pois, conhecendo bem a natureza do todo, deviam ver bem, mesmo nas coisas particulares, como estas eram. Assim nos forneceram claras noções a respeito da velocidade dos astros, o amanhecer e o pôr do sol, como também sobre a geometria, a aritmética e não menos sobre a música. Essas ciências parecem de fato serem irmãs (47 B1 DK).

A aproximação desse fragmento de Arquitas ao segundo testemunho de Platão acima sugere um caminho de solução para a aparente contraditoriedade da tradição platônica: enquanto, na primeira passagem, Platão entenderia referir-se ao protopitagorismo, a segunda diria respeito ao pitagorismo a ele contemporâneo, notadamente à figura de Arquitas. Pois, não somente as comunidades pitagóricas já teriam desaparecido após as revoltas antipitagóricas de meados do $V$ século a.C, mas o próprio Arquitas aparece sempre na tradição como um pensador e cientista independente, e, portanto, não utilizável para

${ }^{18}$ Cf. para a mesma aproximação entre música e astronomia também Crátilo (405d). Para uma resenha da recusa do empirismo e a irmandade das duas ciências, cf. Vegetti (1999: 86-88) e Meriani (2003). 
falar da comunidade pitagórica e seu bios. ${ }^{19} \mathrm{O}$ que se vê em ação aqui é a dimensão diacrônica em busca de um caminho pelos diferentes estratos das tradições que contribuem para a definição da categoria historiográfica do pitagorismo. ${ }^{20}$

Em relação ao testemunho aristotélico, para além da discutida expressão oi kaloúmenoi pythagoreíoi, mencionada anteriormente, as referências às contribuições pitagóricas à matemática e à física (cf. Met. 985b23) fariam pensar em uma identificação prioritária do pitagorismo com uma comunidade científica e filosófica. E, todavia, os fragmentos que restam das obras do corpus aristotélico expressamente dedicadas ao estudo dos pitagóricos (fr. 191-205 Rose) parecem, ao contrário, revelar outras abordagens: Aristóteles se ocupa aqui da vida de Pitágoras e dos akoúsmata e sýmbola que orientam a vida comunitária pitagórica. Célebre é o testemunho do fr. 192 Rose:

Aristóteles em sua obra Sobre a filosofia pitagórica dá notícia do fato de que seus seguidores custodiam entre os segredos mais rígidos esta distinção: dos seres viventes dotados de razão, um é o deus, o outro é o homem, o terceiro possui a natureza de Pitágoras (14 A7 DK = Iambl. VP: 31).

Portanto, mesmo o testemunho de Aristóteles, como é o caso daquele de Platão, não é decisivo para compreender qual seria a característica principal da comunidade, se a da investigação científica ou aquela da vida em comum orientada por akoúsmata e sýmbola, como aquele acima citado.

É provável que a pergunta, feita idealmente a Platão e Aristóteles sobre qual seria a característica saliente da koinonía pitagórica, seja de fato mal colocada. A aporía sugere que seja preciso, portanto, por um lado, rever metodologicamente a própria tentativa de separação entre as duas alternativas, por outro, retomar a busca pelas modalidades dessa comunidade de um ponto de vista textual alternativo.

\footnotetext{
${ }^{19}$ Aristóteles, de fato, trata de Arquitas não no interior dos assim chamados pitagóricos, mas dedica ao filosofo-rei de Tarento uma consideração a parte. Cf. também abaixo (4.1.2).

${ }^{20}$ Sobre a autenticidade do fr. 1 de Arquitas, levantaram dúvidas Burkert (1972: 379) e Centrone (1996: 70n 21). Para a ideia da inatualidade de Arquitas para uma discussão sobre a comunidade protopitagórica, cf. Centrone (1996: 70).
} 


\subsection{A KOINONía PITAgórica}

Os modelos históricos gregos de associações são fundamentalmente de dois tipos: o thiasos e a hetairía. Enquanto o primeiro está mais diretamente ligado à prática comum de cultos, à partilha de ritos e saberes mistéricos, a hetairía está mais ligada à ideia de uma associação de philoí, no sentido político de aliados e confrades que se encontram em um clube privado. A comunidade pitagórica é quase que unanimemente considerada pela tradição uma hetairía, ainda que bastante sui generis: de fato, procurando justificar a violenta revolta contra os pitagóricos, Jâmblico revela o sentimento de estranhamento da população com relação à comunidade:

Tomaram a frente da revolta exatamente aqueles que estavam em relações de parentesco mais próximas com os pitagóricos. $\mathrm{E}$ a razão era que estes exatamente como a população em geral - ficavam irritados com a conduta dos pitagóricos em praticamente qualquer aspecto dela, na medida em que esta era diferente daquela dos outros (Iambl. VP: 255).

Essa diferença da comunidade, ligada a algumas práticas estranhas à cultura e economia daquele tempo, como aquela da partilha dos bens, era, com toda probabilidade, parte essencial do motivo da inimizade - acenada no testemunho acima - por parte das próprias famílias dos membros da comunidade. Sublinha-se acima, no interior do panorama da crítica, a questão da presença política da comunidade pitagórica: essa presença sugeriria que a melhor identificação seria mesmo com o modelo da hetairía. E, todavia, as fontes são bastante insistentes em nos apresentarem uma comunidade francamente dedicada ao culto e a uma vida comunitária baseada em akoúsmata e sýmbola, isto é em palavras secretas e sinais de identificação. Com isso, ganharia força a hipótese contrária, isto é, de a comunidade pitagórica encontrar seu lugar tipológico mais próprio no âmbito do thiasos. ${ }^{21}$

Baseando-se na inegável característica da diferença da comunidade, Burkert (1982: 2-3, 19), seguido por Riedweg (2002: 166-171), considera que a melhor definição para a comunidade pitagórica seja o termo seita. ${ }^{22}$ Consciente do uso comum depreciativo do termo, que leva diversos autores, incluindo o presente, a preferir uma designação mais neutra, como aquela até aqui usada de comunidade, a traduzir o grego koinonía, Burkert reclama para

${ }^{21}$ Para ampla resenha da terminologia utilizada pelas fontes antigas para designar a comunidade pitagórica, cf. Minar (1942: 15-35). Tanto Philip (1966: 144) quanto Zhmud (1992: 241-1) consideram improvável a associação dos pitagóricos com o modelo do thíasos por causa da evidente atuação política da comunidade. Centrone (1996: 67-68) adota uma posição menos cética, reconhecendo que, ainda que alguns traços esotéricos da comunidade fossem de fato sublinhados pela tradição tardia, esse fato não autoriza a negar tout court qualquer valor histórico a eles.

22 O primeiro a usar o termo sekte é Rohde (1898: 103ss.). O uso de uma terminologia advinda da sociologia da religião não é incomum: Toynbee (1939: 84) e Jaeger (1947: 61) chegam a utilizar o termo "church" para referir-se à comunidade pitagórica. 
o termo seita a vantagem de um uso mais técnico, sociológico, na esteira dos trabalhos de Bryan Wilson e Arnaldo Momigliano (Burkert 1982: 3).

Dessa forma, poder-se-ão identificar, no pitagorismo, as características mínimas que definem uma seita, do ponto de vista da sociologia dos grupos religiosos. Essas características contribuem para a descrição da comunidade pitagórica como de um grupo de proporções numéricas bastante reduzidas, de caráter elitista, modos alternativos e algum nível de sigilo: encontros regulares ou vida em comum, certa partilha econômica e espiritual, submissão à autoridade de um guia carismático e forte sentimento identitário que leva à separação das pessoas entre nós e eles. Ações de vingança contra os apóstatas, prescrições reprodutivas que garantam a sobrevivência diacrônica da comunidade e intensa mobilidade geográfica concluem um retrato no qual, como se verá, podem ser reconhecidas as características salientes do estilo de vida pitagórico.

$\mathrm{Na}$ peneira da tradição, de fato, a classificação proposta por Burkert revela-se em geral bastante apropriada. Serão visitadas algumas das tradições mais salientes que dizem respeito a essa possível identificação do pitagorismo com uma seita. As duas Vidas, de Porfírio e Jâmblico (de maneira especial esta última), são ricas fontes de informação sobre a comunidade e as regras de seu bios. Ainda que marcadas por interpolações tardias, é certamente possível identificar estratos mais antigos da tradição em muitos dos testemunhos que irão receber nossa atenção a seguir. ${ }^{23}$

Número limitado. Os pitagóricos, ainda que influentes nas cidades por eles administradas na Magna Grécia, constituíram sempre uma comunidade minoritária, tanto no interior dos grupos aristocráticos das mesmas cidades como no âmbito maior da cultura intelectual de seu tempo. Apesar de os quatro discursos políticos de Pitágoras, na ocasião da chegada em Crotona, terem conquistado - segundo Porfírio (VP: 20) e Jâmblico (VP: 30) - um auditório de duas mil pessoas, somente seiscentas delas se tornaram mesmo discípulos, "não somente conduzidos por ele à filosofia, mas também prontos a 'viver em comum', como se dizia, conforme seus preceitos" (Iambl. VP: 29). ${ }^{24}$ A tradição parece sugerir já uma seleção inicial, portanto. $\mathrm{O}$ mesmo catálogo de Jâmblico acima citado, em sua intenção de contar os pitagóricos, pressupõe certamente um número limitado deles.

Caráter elitário. A tradição anteriormente referida dos discursos públicos de Pitágoras, por ocasião de sua chegada em Crotona (Porph. VP; 20, Iambl. $V P$ : 30), e que resulta na adesão dos seiscentos, poderia sugerir que fazer parte da comunidade e ter acesso aos seus ensinamentos fosse algo fácil. Uma tradição de Antifonte, citada por Porfírio (VP: 9), recorda que, ainda em Samos, Pitágoras teria fundado um didaskaleion, uma escola: chamada de

\footnotetext{
${ }^{23}$ Para uma avaliação da influência da tradição pitagórica sobre a evolução do gênero literário das Vidas de filósofos no mundo antigo, cf. Goulet (2001: 23-61, espec. 32-34, com uma análise de Porph. VPe Iambl. VP).

${ }^{24}$ Com o número de 600 concorda Diógenes Laércio (Vitae VIII. 15). Já para Apolônio de Tiana o número era ainda mais restrito, limitando-se a 300 (FGrHist 1064 F; 254).
} 
hemiciclo de Pitágoras, que reunia os que discutiam sobre negócios públicos. Ele próprio, todavia, refugiava-se em um ántros, uma gruta, onde poderia consagrar-se exclusivamente à filosofia, a sugerir que este caráter elitário e exclusivo da comunidade pitagórica estaria presente já mesmo nos anos iniciais da formação de Pitágoras.

O mesmo caráter exclusivista pode ser observado no rígido critério de admissão à própria comunidade, marcado por um período probatório de dokimasía:

Quando alguns jovens chegavam com o desejo de conviver com ele, não os admitia imediatamente, esperando que fossem examinados e julgados. Primeiramente, inteirava-se das relações que eles mantiveram com seus genitores e os outros parentes antes de se aproximarem a ele; depois, verificava quem entre eles ria de maneira inconveniente, calava ou falava de modo despropositado e ainda quais eram suas paixões, quem eram seus parentes, que relações mantinham com estes, a que atividades dedicavam a maior parte do dia e qual era o motivo de sua alegria e dor [...]. Aqueles que superavam este exame eram desprezados por três anos, com a intenção de colocar à prova sua firmeza e real amor pelo conhecimento [...]. Após esse período, impunha aos aspirantes um silêncio de cinco anos, para testar sua continência. Pois de todas as provas de autocontrole, aquela de frear a língua é certamente a mais dura, como bem demonstram os fundadores dos ritos mistéricos (Iambl. VP: 71-72).

A fonte da qual bebem tanto Porfírio como Jâmblico para estas referências ao bios pitagórico é Nicômaco. A suspeita de que essa extrema rigidez da organização do acesso à comunidade pitagórica (três anos de descaso, aos quais eram seguidos mais cinco de silêncio) seja, na realidade, uma retroprojeção dele, é levantada tanto por Von Fritz (1940: 220) como por Philip (1966: 140). E, todavia, há testemunho paralelo em Diógenes Laércio (VIII 10), cuja fonte seria desta vez Timeu, que confirmaria uma provável antiguidade do testemunho:

[Seus discípulos] permaneciam em silêncio por cinco anos, limitando-se a escutar seus discursos, sem nunca ver Pitágoras, até que não superassem a prova; a partir desse momento, tornavam-se parte de sua casa e eram admitidos à sua presença (D. L. Vitae VIII 10). ${ }^{25}$

Vida em comum (cenóbio) e comunhão dos bens. O testemunho acima citado é rico de outros sinais sectários, como o do sigilo, e, de maneira especial, da comunhão dos bens. A mesma passagem de Jâmblico acima citada, referida à dokimasia dos jovens aspirantes, detalha as modalidades dessa partilha:

Nesse período, os bens de cada um, isto é, suas propriedades, eram colocadas em comum e confiadas aos membros notáveis da comunidade encarregados disso, chamados políticos: alguns deles eram administradores, outros legisladores (Iambl. VP: 72).

\footnotetext{
${ }^{25}$ Cf. para esta referência Centrone (1996: 74).
} 
O testemunho mais antigo da comunhão dos bens parece ser novamente o de Timeu: um escólio ao Fedro (Schol. In Phaedr: 279c), corresponde literalmente a uma passagem do livro IX de Timeu:

Ora, quando os jovens vinham até ele e queriam viver com ele, não lhes permitia fazê-lo, mas respondia que era necessário que colocassem em comum seus bens (Schol. In Phaedr.: 279c = FGrHist: 566 F 13).

Trata-se aqui do célebre dito koinà tà phílôn (ou koinà tà tôn phílôn) que aparece referido aos pitagóricos por Platão. ${ }^{26}$ Não procede a observação de Philip (1966: 142) pela qual em Aristóteles, ao contrário, "seu significado é bastante não pitagórico" (its meaning is quite un-Pythagorean”): o trecho da Ética Nicomaqueia por ele citado (EN 1159b: 25-32), ao contrário, ainda que sem uma referência direta à origem pitagórica do dito, insere o koinà tà philôn no interior de uma discussão, de marco notadamente pitagórico, sobre a comunidade de amigos como promotora de justiça e, por consequência, em evidente sentido econômico:

Parece, portanto, conforme dissemos no início, que amizade e justiça digam respeito às mesmas coisas e se deem entre as mesmas pessoas. De fato, em cada comunidade parece haver algo de justo e amizade. Assim chamam-se amigos os companheiros de navegação e de armas, e da mesma maneira aqueles que fazem parte de outras comunidades. Conforme participam da comunidade, há amizade, e também justiça. E diz bem o provérbio "as coisas dos amigos são comuns”, pois a amizade está na comunidade (EN 1159b: 25-32).

Não por acaso, diversos autores utilizaram a expressão comunismo, ainda que muitas vezes entre aspas, considerando o evidente anacronismo do termo - para indicar essa prática do mote koinà tà phílôn entre os pitagóricos. ${ }^{27}$ Essa mesma relação entre phíloi e dikaion é encontrada em Platão, que, por outro lado, não tem dúvidas em referir o dito diretamente aos pitagóricos. Não casualmente essa ligação entre pitagorismo e a philía aparece em um passo central de República. No começo do livro V (449c), Adimanto, a convite de Polemarco, repreende Sócrates por ter deixado de lado, em sua argumentação sobre a cidade justa e perfeita, o problema levantado pelo dito koiná tà phílôn aplicado a mulheres e filhos, fazendo assim surgir a suspeita de querer fugir da questão:

Parece-nos que você esteja querendo se safar rapidamente, roubando uma parte inteira do discurso (e não certamente a menor) para não ter que discuti-lo, que tenha pensado em fugir deixando cair, de leve, aquele dito pelo qual, com relação às mulheres e às crianças, para todos deveria ser evidente que tudo deve ser em comum entre os amigos (Resp. V: 449c).

${ }^{26} \mathrm{Cf}$. as referências aos passos platônicos nos parágrafos imediatamente a seguir.

${ }^{27}$ Entre eles, Minar (1942: 29, 32, 35), Conybeare, em sua tradução da Vida de Apolônio de Tiana de Filostrato (1948-50) e Burkert (1982: 15). 
O dito, introduzido phauloss, de leve, no livro IV (424a), requer ao contrário - ao dizer de Adimanto - uma explicação com relação ao trópos tês koinonías (V: 449d), ao tipo, aos modos dessa comunhão. Dessa forma, Sócrates passará a representar em detalhes o gynaikeion dráma da cidade. O léxico dessa página é impregnado de pitagorismo: tanto a comunhão dos bens (e de mulheres e filhos), como a importância da escuta como característica do bios e da cidade justa, remetem imediatamente para as características da vida pitagórica apontadas pela tradição. ${ }^{28}$

As modalidades da comunhão dos bens deviam alcançar articulação maior do que a da simples organização da partilha dos bens em comunidades de vida cenobítica. É certamente o que sugere o caso de Clínias de Tarento e Proros de Cirene:

Narra-se que Clínias de Tarento, quando soube que Proros de Cirene, um seguidor da doutrina pitagórica, estava correndo o risco de perder seu patrimônio, recolheu uma soma de dinheiro e embarcou em direção a Cirene, colocando em ordem os negócios de Proros, sem importar-se não somente com suas perdas financeiras, como também com os perigos da navegação (Iambl. $V P: 239)$.

A anedota revelaria mais uma vez a radicalidade desta comunhão.

Reveladora é também a história edificante de um pitagórico que havia ficado gravemente doente durante longa viagem. Ao dono da pensão que o hospedava em seus últimos dias de vida e que cuidava dele com grande generosidade, o pitagórico, após ter gravado um símbolo sobre uma tabuinha:

Pediu que o pendurasse fora da porta da pensão e que ficasse atento caso algum transeunte reconhecesse o sinal; pois, nesse caso, esta pessoa reembolsaria a ele todas as despesas e o agradeceria por sua conta. Quando o hóspede morreu, o dono da pensão o sepultou e cuidou com toda atenção do caixão - sem preocupar-se com as despesas ou em receber algum reconhecimento de quem eventualmente fosse identificar a tabuinha. E, todavia, por curiosidade com relação à ordem recebida, quis colocá-la à prova, expondo a tabuinha para que pudesse ficar sempre visível. Muito tempo depois, um pitagórico que passava por lá reconheceu o símbolo. Perguntou então o que havia acontecido e deu para o dono da pensão uma quantia muito maior daquela que foi desembolsada (Iambl. VP: 238).

A história não diz de que símbolo se trata. Todavia, com base em uma página de Luciano (Jacoby I: 330), apreendemos que o sinal de reconhecimento dos pitagóricos era o pentagrama, sendo utilizado até mesmo como assinatura em suas cartas. ${ }^{29}$ Essas histórias são facilmente datáveis em época tardia. Ainda

${ }^{28}$ Platão refere o dito aos pitagóricos também em Lisis 207c e Leis 739c.

${ }^{29}$ Cf. para esta tradição também Jâmblico (Iambl. VP: 88), em relação ao fato que teria sido exatamente a revelação do segredo do pentagrama a fazer Hipaso merecer a expulsão da comunidade. 
assim, referem-se a uma tradição já antiga e que devia ser muito forte, resistindo como memória da centralidade da comunhão de bens entre os pitagóricos.

A amizade pitagórica. O tema da philía é presente desde aqueles que são considerados os primeiros discursos públicos de Pitágoras, os célebres quatro lógoi, proferidos quando de sua chegada em Crotona. Entre outros, no Primeiro Discurso, dirigido aos jovens, Pitágoras os exorta a cuidar bem dos amigos:

Afirmava que teriam sucesso se mesmo nas relações entre eles se comportassem deixando claro que não seriam nunca hostis aos próprios amigos; ao contrário, estariam prontos a qualquer momento a se tornarem quanto antes amigos de seus próprios inimigos (Iambl. VP: 40). ${ }^{30}$

A discussão pitagórica sobre a philía extrapola o âmbito da gestão da vida comunitária, para alcançar o patamar de um conceito-chave para a compreensão de toda a realidade. Um exemplo disso é o testemunho de Jâmblico (Iambl. $V P:$ 229-230; VP: 69-70) que enumera os seis aspectos da philía ensinada por Pitágoras: dos deuses para com os homens, das doutrinas entre elas, da alma com o corpo, dos homens entre eles e com os animais, e do corpo mortal em si mesmo. ${ }^{31}$

Por ser tão proverbial, esta philía entre os pitagóricos mereceu diversas histórias que beiram o lendário, mas que, ainda assim, são significativas para compreender a ética da philía que regia as comunidades pitagóricas: uma das mais significativas é certamente aquela, lembrada por Aristóxeno, da prova radical da amizade entre dois pitagóricos, Fintias e Damon, planejada pelo tirano de Siracusa, Dionísio. Aristóxeno afirma tê-la ouvido da boca do próprio tirano que - caído em desgraça - foi ser professor em Corinto:

Um dia Dionísio quis colocá-los à prova, pois alguns asseguravam que se os tivesse preso e aterrorizado, não teriam permanecido fiéis uns aos outros. Ele

${ }^{30}$ Cf. o que foi dito acima em relação ao valor dos discursos como testemunhos da fundação da comunidade pitagórica, especialmente em relação aos estudos neste sentido, de Rostagni (1922) e De Vogel (1966) - no entanto, com a necessária prudência acima indicada.

31 Iambl. (VP: 229-230): "Pitágoras ensinou com muita clareza a $\varphi \imath \lambda i ́ \alpha$ de todos para com todos a começar pela $\varphi \imath \lambda i^{\alpha}$ : 1$)$ dos deuses para com os homens, por meio da piedade e de um culto baseado no conhecimento; 2) das doutrinas entre elas; 3) em geral da alma com o corpo e da parte racional da alma com a parte irracional graças à filosofia e à contemplação que lhe é própria; 4) dos homens entre eles: dos cidadãos pela estrita observância da lei, entre seres humanos de diversas etnias por meio do correto conhecimento da natureza [humana], do homem para com a mulher ou filhos ou irmãos ou parentes por meio de uma comunhão indestrutível; em resumo $\varphi$ i $\lambda$ ía de todos para com todos e até 5) de alguns animais irracionais por causa de um sentimento de justiça e de uma natural proximidade e solidariedade; 6) enfim, do corpo mortal com si mesmo, pacificação e conciliação das forças contrárias que nele se escondem por meio da saúde e do regime [de vida] que a essa tende, e temperança por meio da imitação da condição de bem-estar que caracteriza os elementos celestiais. O fato de uma única

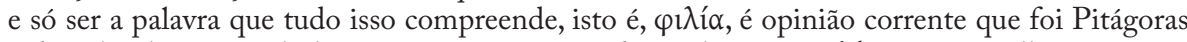
a descobri-lo e torná-lo lei; este ensinava a seus discípulos uma $\varphi \imath \lambda i ́ \alpha$ tão maravilhosa, que até hoje muitos dizem, a respeito daqueles que são ligados entre si por uma recíproca benevolência, tratar-se de pitagóricos". 
então agiu da seguinte forma: Fintias foi preso e conduzido na frente do tirano, que o acusou de conspiração contra ele, acrescentando que o fato já havia sido comprovado e que, portanto, o condenaria à pena capital. Fintias respondeu: "se assim decidiste, me seja ao menos concedido o restante deste dia para acertar meus negócios e aquele de Damon (era de fato companheiro e sócio dele e, como mais idoso, havia tomado conta de seus negócios). Fintias, portanto, pedia para ser deixado ir e oferecia Damon como fiador [para ficar no lugar dele]. Dionísio concordou e foi chamado Damon que, ao saber o que havia ocorrido, aceitou imediatamente ser fiador de Fintias e ficou esperando este voltar. (61) Dionísio, de sua parte, havia ficado impressionado com o ocorrido, enquanto aqueles que haviam inicialmente proposto a prova zombavam de Damon, dizendo que seria ali abandonado. Mas ao pôr do sol, Fintias chegou, pronto para morrer. E todos ficaram maravilhados; Dionísio, de sua parte, abraçou afetuosamente os dois e pediu para ser acolhido como terceiro na philía deles (Porph. VP: 60-61).

Portanto, a insistência da tradição é para com a proverbial fidelidade da philía pitagórica. Outra narrativa que representa bem esta fidelidade ao amigo, mas que Rohde (1872: 50) define simplesmente como boba (eine alberne Geschichte), é a da philía entre Lísis e Eurífamo:

Quanto aos pactos estabelecidos, Pitágoras preparou com tamanha eficácia seus discípulos para respeitá-los sinceramente, que se narra que uma vez Lísis, saindo do tempo de Hera, após ter feito suas orações, encontrou Eurífamo de Siracusa, seu companheiro, que por sua vez estava entrando no templo. Por ter este último solicitado a ele que o aguardasse enquanto realizava suas orações, Lísis sentou-se em um banco de pedra próximo à saída do templo. Após as orações, Eurífamo, imerso em seus pensamentos e tomado como estava por uma profunda reflexão, saiu do templo por outra porta. Lísis, de sua parte, permaneceu imóvel, esperando durante o dia todo e a noite inteira, e boa parte do dia seguinte. E provavelmente teria ficado muito mais, se, no dia seguinte, Eurífamo, que se havia dirigido ao auditório, não se tivesse recordado do fato, após ouvir que Lísis estava cercado de companheiros da comunidade. Somente então foi encontrá-lo: este, conforme o pacto, estava esperando por ele. Levou-o embora, explicando assim o motivo de seu esquecimento: "foi um deus a causar em mim este esquecimento, para que pudesse colocar à prova tua firmeza em observar os pactos" (Iambl. VP: 185).

Por trás da anedota, esconde-se certamente a memória da dimensão incondicional da fidelidade na philía pitagórica, que instaura uma identidade de grupo tão forte a ponto de configurar as relações a partir da alternativa nós e eles, e tornar-se proverbial no mundo antigo.

Vingança contra os apóstatas. É com toda probabilidade novamente Timeu a descrever, no trecho imediatamente sucessivo àquele acima citado em relação ao critério de admissão e às formas da dokimasía, os procedimentos de expulsão dos apóstatas, isto é, dos que, por algum motivo, traindo as regras do bios, eram excluídos da koinonía: 
No caso em que fossem recusados, recuperavam, em dobro, seus pertences, enquanto "aqueles que ouviam juntos" (homakooi), como eram chamados todos os seguidores de Pitágoras, levantavam para eles uma lápide fúnebre, como se fossem mortos [...]. Se em outra ocasião acontecia de encontrar quem havia sido recusado, o consideravam como um estranho qualquer, e não como um companheiro, pois havia morrido para eles (Iambl. VP: 73-4).

Tratava-se de uma exclusão definitiva, portanto, que não previa evidentemente alguma possibilidade de volta, como é indicado inconstestavelmente pela comparação com a própria morte.

Modos alternativos. A vida cotidiana na comunidade pitagórica previa uma organização do tempo e do espaço pouco comuns para os padrões da época. A descrição mais coerente desta pode ser encontrada em Jâmblico:

$\mathrm{Na}$ parte da manhã realizavam passeios solitários em lugares onde houvesse quietude e tranquilidade, como templos e bosques, e algo que alegrasse o espírito. Estavam de fato convencidos de que não se devia encontrar ninguém antes de ter arrumado a alma e ordenado o pensamento [...]. Depois do passeio matutino, reuniam-se entre eles, normalmente em santuários, ou em lugares de natureza semelhante. Dedicavam estas ocasiões ao ensino e à aprendizagem e à correção do caráter. Em seguida, dedicavam-se à cura de seus próprios corpos. [...] No almoço, comiam pão, mel, mel misturado com cera, e não tomavam vinho ao longo do dia. Dedicavam as horas da tarde aos negócios políticos, tanto os internos quanto os externos. [...] Ao aproximar-se do entardecer, voltavam a fazer os passeios, todavia não sozinhos, como de manhã, e sim em grupos de dois ou três, relembrando as coisas aprendidas e exercitando-se com belas ocupações. Depois do passeio, tomavam banho e se dirigiam ao banquete comum [...]. Após o banquete, ofereciam libações e acontecia a leitura [...]. Uma vez pronunciadas estas palavras, cada um voltava para a sua própria casa. Vestiam vestes brancas e puras, e usavam lençóis também brancos e puros, de linho, pois não usavam peles [de cordeiro]. (Iambl. VP: 96-100). ${ }^{32}$

A imagem cenobítica, tipicamente monástica, da vida pitagórica, pertence certamente a uma tradição tardia, provavelmente mediada pela tradição estoica medioplatônica, obedecendo mais diretamente ao ideal de vida calma e transcorrida em lugares bucólicos do ideal da vida filosófica helenística e depois imperial. Chama especialmente atenção a indicação da leitura em comum, mais bem especificada por Jâmblico logo em seguida (VP: 104) com relação ao que é chamado de didaskalía diá tôn sýmbolôn, isto é, da explicação dos sinais: uma forma de exegese que incluiria, ao lado da prática oral, a utilização de uma série de diferentes tipos de escritos, desde anotações até publicações ecdóticas. É obviamente impensável uma complexidade literária como esta para os séculos $\mathrm{VI}$ e $\mathrm{V}$ aEC. A imagem deverá, portanto, corresponder mais provavelmente

32 Passagem paralela em Porfírio (VP: 32). O testemunho é com toda probabilidade aristoxênico, de maneira especial em sua parte final (Burkert 1982: 16). Sobre a recepção por Aristóxeno da ética pitagórica, no quarto século aEC e em âmbito peripatético, cf. os recentes estudos de Huffman (2006; 2008). 
à descrição de uma mesa de estudo da Biblioteca de Alexandria, em época helenística. ${ }^{33}$

O vegetarianismo é certamente outro sinal de um estilo de vida culturalmente alternativo dos pitagóricos. Como vimos acima, nos estudos de Detienne, a dieta vegetariana implica a recusa radical de uma prática religiosa e social, aquela do sacrifício animal, que constitui um dos pilares da cultura grega antiga. $\mathrm{O}$ vegetarianismo está diretamente ligado à crença na metempsicose e no parentesco universal entre todos os seres viventes, conforme mencionado no resumo inicial das doutrinas de Pitágoras por Porfírio (VP: 19):

Algumas de suas [de Pitágoras] afirmações ganharam notoriedade praticamente geral: 1) afirma que a alma é imortal; 2) que transmigra em outras espécies de seres vivos; 3) que, periodicamente, o que já aconteceu uma vez volta a acontecer, e nada é absolutamente novo; e 4) que todos os seres animados devem ser considerados como do mesmo gênero. Ao que parece, foi mesmo Pitágoras a introduzir pela primeira vez estas crenças na Grécia (Porph. VP: 19).

A menção à introdução desta crença na Grécia pressupõe, mais uma vez, estranheza geral a ela, configurando-se com isso a imagem de uma seita marcada por uma subcultura alternativa. ${ }^{34}$

Consequência do vegetarianismo é o outro sinal da postura alternativa dos pitagóricos: a famosa tradição de recusar-se a realizar sacrifícios de animais. Todavia, por ser ponto central do sistema de crenças tradicionais e elemento fundamental das festas religiosas políades, a prática devia entrar em conflito de forma tão radical com o sistema religioso tradicional ao ponto de merecer uma flexibilização quase imediata. É o que revelaria certa racionalização do sacrifício de animais conforme aparece em Jâmblico (VP: 85) e, sobretudo, em uma página do De Abstinência de Porfírio:

Por esse motivo, os pitagóricos, acolhendo essa tradição, abstinham-se ao longo de toda a vida de comer animais e, quando oferecíam aos deuses algum animal no lugar de si mesmos, depois de tê-lo somente degustado, viviam na realidade intocados pelos outros animais (Porph. De Abst. 2.28: 2).

Ainda que desarmada, a tradição de uma prática contracultural como esta, todavia, permanence ao longo dos séculos, apontando mais uma vez para uma postura alternativa e sectária da comunidade. ${ }^{35}$

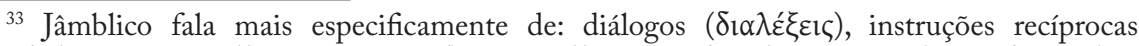

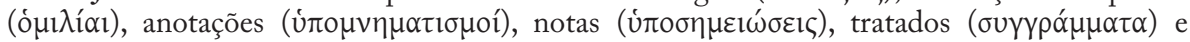

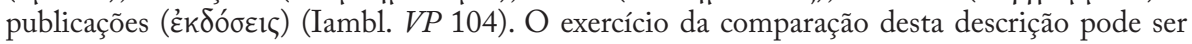
estendido ainda mais, englobando a semelhança dela com a descrição dos essênios em Flávio Josefo (A Guerra Judaica II, 128-33) e dos terapeutas judeus do lago de Mareótida descritos por Fílon (De vita contemplativa II), apesar das reservas expressas por Centrone (2000: $161 \mathrm{n} 47) \mathrm{em}$ relação a esta última.

${ }_{34}$ À confirmação disso, Burkert define a metempsicose como "um corpo estranho no interior da religião grega" (1977: 430).

35 Burkert (1972: 182) assim comenta a acomodação à cultura majoritária da prática da 
Silêncio e segredo. Diversas citações acima recordam a obrigação do silêncio e do segredo com relação às doutrinas. É esta uma das características mais lembradas pela tradição. $\mathrm{O}$ testemunho mais antigo é certamente aquele do orador Isócrates, contemporâneo de Platão: "ainda hoje mais são admirados aqueles que se professam seus discípulos [de Pitágoras] e se calam, do que aqueles que obtêm grandíssima fama através da palavra" (Isócrates, Busiris 29 = 14 A4 DK). Mesmo alguns fragmentos da Comédia Intermediária (DK 58 E) recordam essa obrigação do silêncio: "era necessário suportar a escassez de comida, a sujeira, o frio, o silêncio, a severidade e a falta de higiene" (Alexis. $A$ Pitagorizante, fr. 201 Kassel-Austin $=58$ E1 DK).$^{36}$

Um célebre caso, melodramático, de quebra desta obrigação do segredo é o da revelação, por parte de Hipaso, da doutrina da incomensurabilidade, ou, em outra versão, da inscrição do dodecaedro em uma esfera. ${ }^{37} \mathrm{~A}$ tradição matemática do pitagorismo atribui a Hipaso, além disso, o roubo da originalidade da descoberta, que foi certamente Dele (tồ andrós, Iambl. VP: 88), isto é, do também inominável Pitágoras. Nessa atribuição, revela-se um dos motivos comuns da insistência no segredo das doutrinas: diante da resistência dos acusmáticos em considerarem como parte fundamental da tradição pitagórica questões matemáticas desse gênero, o lado dos matemáticos utiliza a escamoteação típica do argumento de autoridade, atribuindo-as diretamente a Ele. De fato, da mesma maneira, quando - em época helenística - se inicia vasta produção de apócrifos, o argumento da consignação do segredo sobre as doutrinas entre os primeiros pitagóricos servirá ao propósito de justificar o aparecimento somente tardio de cartas atribuídas falsamente a Pitágoras ou aos primeiros familiares ou discípulos. ${ }^{38}$ Com razão, anota Huffman (2008a), uma testemunha importante como Aristóteles não revela em seus escritos alguma dificuldade em ter acesso aos textos pitagóricos (ao contrário, escreve três livros sobre Arquitas). Disso deriva que: ou grande parte das doutrinas

renúncia ao sacrifício de animais: "It would have meant a complete overturn of traditional ways. As far as we can judge, the Pythagoreans sought compromise the matter; an acusma asks, "What is most just?" and answers, "To sacrifice." An accommodation of the doctrine of metempsychosis and the traditional way was found, because it had to be found".

${ }^{36}$ Para uma visão geral sobre o pitagorismo na comédia intermediária cf. Bellido (1972) e Chevitarese (2004).

${ }^{37}$ É Burkert (1972: 455) quem fala de um "veritable melodrama in intellectual history" em relação a essa tradição dos incomensuráveis. Refere-se provavelmente a Hipaso o capítulo de Jâmblico (VP: 74) que menciona a possibilidade de alguém instruído nas ciências ser expulso da comunidade, ainda que não o cite nominalmente. Para a referência explícita a Hipaso, cf. Iambl. VP: 88, 247.

${ }^{38}$ Cf., para a coleção destes apócrifos, Thesleff (1965), além da Introdução a esta literatura (Thesleff 1961). Cf. também Szlezák (1972) para edição e comentário do célebre tratato Sobre as dez categorias do Pseudo-Arquitas; e Centrone (1990) para uma edição e comentário de alguns tratados morais pseudopitagóricos. Até mesmo de Filolau se recorda uma quebra do sigilo em ocasião da divulgação dos célebres três livros comprados por Platão (D. L. Vitae VIII. 85). E mesmo essa notícia é utilizada para legitimar um falso pitagórico de idade helenística (já mencionado em D. L. Vitae VIII. 6). Cf., para isso, Burkert (1972: 223-227), Huffman (1993: 12-14) e o que se dirá a seguir (4.1.3.1). 
pitagóricas não eram, de fato, sigilosas, ou o segredo foi "muito mal guardado" (Huffman 2008a: 218).

A controvérsia já antiga sobre a existência de escritos autênticos de Pitágoras deve ser também compreendida no interior dessa tradição. ${ }^{39}$

E, todavia, a presença da obrigação do segredo é tão significativa, especialmente com relação às tradições dos akoúsmata e sýmbola, ao ponto de não poder ser reduzida simplesmente a uma falsificação helenística: esta configura exatamente um dos critérios centrais para a constituição de uma seita, isto é, aquele de uma linguagem esotérica, que precise de senhas específicas para ser compreendida.

Boa solução da questão do segredo na comunidade e literatura pitagórica é aquela proposta por Gemelli (2007b). No interior de atenta análise da linguagem esotérica utilizada pelos pré-socráticos, Gemelli anota que:

É característica do texto esotérico uma estreita ligação entre linguagem e experiência, que nada diz a quem não tiver a capacidade de "tornar concreta" a palavra. $\mathrm{O}$ silêncio pretendido pelos pitagóricos não é um silêncio sobre as palavras, e sim sobre as experiências. Pois umas sem as outras permanecem um cofre trancafiado (Gemelli 2007b: 438). ${ }^{40}$

O segredo, portanto, seria uma estratégia da comunidade para manter as experiências que se desenvolvem em seu interior como prerrogativa exclusiva dos iniciados; a tese de Gemelli é muito convincente e impregnada de consequências para a compreensão da dinâmica esotérica do protopitagorismo.

Guia carismático. A presença carismática do fundador Pitágoras paira sobre as diversas características até aqui detectadas na seita pitagórica. Tanto a referência acima de Aristóteles, de sua natureza intermediária entre deuses e homens (Iambl. VP: 31), como a expressão toû andrós (Iambl. VP: 88) para referir-se a Pitágoras sem nomeá-lo, sugerem de fato a presença de mais esse critério de identificação do pitagorismo como de uma seita. Para além disso, é recorrente a tradição da atribuição da autoridade de praticamente qualquer doutrina ao mestre Pitágoras, lembrada pela expressão Autós épha, ipse dixit (Iambl. VP: 46). A figura de Pitágoras insere-se claramente no padrão do theiós anér, do homem divino da tradição grega antiga, cujas características foram habilmente resumidas por Achtemeier:

As características do theios anér podem ser brevemente resumidas: um nascimento maravilhoso, uma carreira marcada pelo dom de uma linguagem persuasiva e dominadora, a capacidade de fazer milagres, incluindo curas e

${ }^{39}$ Cf. Diógenes Laércio (Vitae VIII. 6-8). Para um comentário a esta controvérsia cf. Centrone (1992).

${ }^{40}$ Orig.: "ist ein Charakteristikum esoterischer Texte, die eben für denjenigen nichtssagend sind, dem die Fähigkeit fehlt, dem Wort 'einen konkreten Sinn zu verleihen'. Das Scheweigen, das die Pythagereer verlangten, bezog sich nicht auf das Gesagte, sondern auf das Erlebte. Denn das eine blieb ohne das andere ein versiegelter Schrein." 
adivinhações, e uma morte de alguma maneira extraordinária (Achtemeier 1972: 209).41

Os diversos testemunhos sobre os poderes sobrenaturais de Pitágoras e, de maneira especial, de seus milagres inserem-se no interior da construção desta figura extraordinária.

Macris (2003: 265-270), ainda que reconheça que o termo théios anér seja o mais aderente às fontes, prefere -, na esteira de Riedweg, utilizar o mais genérico "carismático", justificando a escolha da seguinte maneira:

Se preferimos o qualificativo 'carismático'é porque, em sua acepção sociológica propriamente weberiana, evoca inevitavelmente, para além dos dons excepcionais de Pitágoras, a relação de dominação que está estabelecida entre o mestre e os membros da comunidade que se formou em torno dele (Macris 2003: 270$) \cdot{ }^{42}$

O carisma de Pitágoras, portanto, deverá ser pensado como mais um elemento de coesão da koinonía.

Prescrições reprodutivas. Entre as doutrinas que constituem a comunidade pitagórica como alternativa aos hábitos comuns da sociedade grega, há certamente aquela da ascensão das mulheres ao mesmo status social dos homens. Não acaso a pitagorizante, acima citada como protagonista da comédia de Alexis, é uma personagem bastante recorrente na comédia intermediária. Desde a notícia do sucesso de seus discursos inaugurais em Crotona, a tradição lembra que a comunidade pitagórica que surge em consequência do sucesso deles é composta também por mulheres (Porph. VP: 19-20; Iambl. VP: 30). O primeiro nome lembrado é aquele de Teano: as fontes oscilam entre considerá-la filha ou esposa do fundador. ${ }^{43}$ Para além das anedotas elaboradas para mostrar a força e fidelidade à comunidade das mulheres - é este o caso da grávida Tímica, que resiste à tortura de Dionísio II (Iambl. VP: 194) -, destaca-se uma série de testemunhos relativos à regulação da reprodução e dos rituais a ela conexos, que revelam diferente relação de gênero entre os pitagóricos:

Dizem que, quando Teano foi interrogada sobre quantos dias depois de um intercurso sexual com um homem uma mulher recupera a pureza, teria respondido: "da relação com o próprio esposo, de imediato, daquela com um

${ }^{41}$ Orig.: "The characteristics of the theios anér can be summarized briefly: a wondrous birth, a career by the gift of overpowering persuasive speech, the ability to perform miracles, including healings and foreseeing the future, and a death marked in some way extraordinary".

${ }^{42}$ Cf. Riedweg (2002: 119ss.) para uma descrição aprofundada do modelo sociológico carismático que haveria por trás da figura de Pitágoras. Orig.: "Se nous lui avons préféré le qualificatif 'charismatique' c'est parce que, dans son acception sociologique proprement wébérienne, il evoque inévitablement, au-delà dês dons exceptionnels de Pythagore, la relation de domination qui s'est ètablie entre le maître et lês membres de la communauté qui s'est formée autour de lui" (Macris 2003: 270).

${ }^{43}$ Cf., para uma sinopse das fontes sobre Teano, Delatte (1922: 246-248). 
estranho, nunca”. Exortava a [esposa] que ia ter com seu próprio marido a abandonar, junto com os vestidos, o pudor; e uma vez levantada [do leito], a recuperá-lo junto com esses. E quando lhe foi perguntado: "Quais?", ela respondeu: "aqueles pelos quais me chamam de mulher"(D. L. Vitae VIII. 43).

Veja-se também, na mesma linha, uma das memórias da katábasis de Pitágoras ao Hades: entre outros castigados, ele teria visto os homens que não quiseram ter intercursos sexuais com suas esposas (D. L. Vitae VIII. 21). Jâmblico (VP: 132 e 195) lembra de Pitágoras convencendo os crotonenses a abandonar as concubinas. Aqui não estaria tanto em questão, ao que parece, a isonomia de obrigações morais conjugais entre homens e mulheres, e, sim, uma atitude típica de pequenas comunidades sectárias que, por meio do controle da reprodução no interior do próprio grupo, tende a garantir sua sobrevivência. Os vários ditos dedicados à necessidade de procriar para honrar os deuses, em si aparentemente genéricos, assumem, na relativamente pequena comunidade pitagórica, tons de autêntica dramaticidade..$^{44}$

Intensa mobilidade geográfica. Enfim, uma intensa mobilidade geográfica é implícita à narrativa da anedota acima citada de Tímica, que quando grávida - antes de cair na emboscada de Dionísio II, ser presa e, em seguida, torturada, viajava junto com outros nove companheiros, de Tarento para Metaponto (Iambl. VP: 189-194). A tradição é atribuída a Neantes e foi certamente elaborada conforme o modelo das anedotas biográficas helenísticas. Ainda assim, observa justamente Burkert (1982: 17), revela uma última característica típica de uma seita, aquela da mobilidade de seus membros, pois: "eles seguiam a mudança das estações e escolhiam lugares adequados para suas reuniões” (Iambl. VP: 189). A mobilidade da comunidade significa recusa à pertença a uma cidade específica e a subtituição da relação políade pela relação sectária.

Nesse mesmo sentido, aos critérios acima desenhados para identificar a separação da comunidade pitagórica em sentido identitário, é o caso certamente de acrescentar - à moda de conclusão - o esquema narrativo da fundação da comunidade pitagórica, tanto em Porfírio como em Jâmblico, nos trechos que se seguem imediatamente aos quatro discursos quando da chegada de Pitágoras a Crotona. Ambas as tradições remontam a Nicômaco e seguem esquema muito semelhante:

Com uma única lição pública, conforme afirma Nicômaco, ministrada na ocasião de seu desembarque na Itália, conquistou mais de dois mil ouvintes, tanto que estes não voltaram mais para casa e jamais o abandonaram; ao contrário, constituíram, junto com mulheres e filhos, uma imensa "casa dos ouvintes" e fundaram aquela que todos chamaram Magna Grécia da Itália. Tomaram dele [Pitágoras] leis e prescrições [...] e puseram em comum seus bens (Porph. VP: 20).

\footnotetext{
${ }^{44}$ Cf. Iambl. VP: 84.
} 
Em uma única lição, a primeira por ele ministrada publicamente após ter chegado só à Itália, soube conquistar com suas palavras mais de duas mil pessoas. Estas foram tomadas a tal ponto que não voltaram mais para suas casas e, ao contrário, constituíram, junto com mulheres e filhos, uma imensa "casa dos ouvintes" e fundaram aquela que foi chamada por todos de Magna Grécia. Tomaram de Pitágoras leis e prescrições [...] e puseram em comum seus bens (Iambl. VP: 30).

O esquema narrativo segue de perto o modelo da fundação de uma cidadecolônia: não voltar mais para as próprias casas (oukéti oikáde apéstesan), novo centro comum (omakoeion), enfim nova cidade da qual fazem parte mulheres e filhos, fundada na comunhão dos bens. ${ }^{45}$

A referência à Magna Grécia remete para algo inédito: o termo Megale Hellas não é um polinônimo, e sim um corônimo, isto é, não se refere a uma cidade específica, mas, sim, a um inteiro território (o sul da Itália). Por consequência, o pitagorismo aqui pretenderia mais do que simplesmente fundar uma cidade: em lugar disso, daria aos territórios da Magna Grécia uma unidade política (polizein é o verbo utilizado em ambas as tradições) anteriormente inexistente (Mele 2000: 329).

Visto "de fora", o sistema koinonía-pólis-khóra pitagórico não podia senão parecer como ameaçador para o restante dos poderes constituídos. As notícias das revoltas e das sucessivas crises da presença pitagórica na Magna Grécia revelam um claro incômodo com relação à escola. Entre todas, é significativa a tradição da recusa, por parte dos habitantes de Locros, de acolher Pitágoras fugitivo:

Ouvimos dizer, Pitágoras, que tu és sábio e excepcionalmente talentoso, mas, no que diz respeito a nossas leis, não temos nenhum motivo de pô-las em discussão e, portanto, iremos tentar nos ater a elas. Tu, de tua parte, dirija-te para outro lugar, mas toma o necessário do qual precisas (Porph. VP: 56).

Em que sentido esse projeto político-diplomático de refundar a Magna Grécia correspondia de fato a uma intenção das primeiras comunidades pitagóricas não está claro. Seguramente, todavia, Pitágoras e os seus eram percebidos como uma ameaça às leis e aos costumes autóctones, pois carregavam consigo uma fama de reformismo ético, político e jurídico muito grande: a comunidade pitagórica é percebida como uma metrópolis que permeia toda a Magna Grécia, pronta a refundar, colonizar o território inteiro. A mobilidade das lideranças pitagóricas (assim como do mesmo Pitágoras) e a arqueologia, especialmente das moedas da época, parecem apontar para o fato de que - até as crises do fim do VI e meados do século $\mathrm{V}$ a.C - esse projeto teve bastante sucesso. ${ }^{46}$ Do ponto de vista da literatura pitagórica, ao contrário, a koinonía

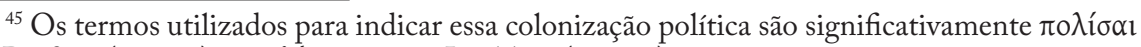

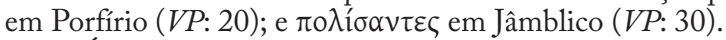

${ }^{46}$ É hoje opinião comum que as revoltas antipitagóricas tenham sido duas, e não somente 
aparece como projeto necessário em consequência da fuga de um regime político tirânico, que, como tal, impede a realização de um bios filosófico. ${ }^{47}$

Em ambos os casos, contudo, a koinonía é, assim, alternativa política à metrópolis real e à sua lógica. Um projeto fundado sobre duas sólidas instituições: o omakoeion, a "casa dos ouvintes", e a partilha dos bens. A comunidade pitagórica é, enfim, uma cidade que escuta e partilha, cujo projeto está baseado, de um lado, sobre o silêncio e a filosofia a ser escutada, do outro sobre um regime econômico comunista, como condições sine quibus non para a realização de um bios filosófico.

Com isso, resolve-se também aquela que poderia parecer como aparente contradição entre as notícias do envolvimento político dos pitagóricos e a característica sectária da comunidade. É, de fato, o caso de concordar com a afirmação de Burkert, pela qual não haveria lugar na Grécia antiga para esse tipo de contradição:

Não há inconsistência entre este lado [político] e o lado religioso e ritual do pitagorismo. De fato, sociedades de culto e clubes políticos são em origem virtualmente idênticos. Todo grupo organizado expressa-se em termos de uma devoção comum, e toda sociedade de culto é ativa politicamente como uma hetairia (Burkert 1972: 119). ${ }^{48}$

Por consequência, é procedente uma imagem da comunidade pitagórica como ao mesmo tempo política e sectária: esta, de fato, propõe-se, em última análise, como alternativa radical à cidade, como uma cidade dentro da cidade. ${ }^{49}$

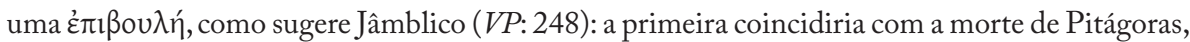
a segunda aconteceria em meados do século $\mathrm{V}$ a.C. Para uma resenha atualizada das posições dos comentadores sobre a crise das comunidades pitagóricas, cf. Musti (1990: 62).

${ }^{47}$ Trata-se da tradição que vê Pitágoras exilado por causa do desentendimento com o tirano de Samos Polícrates (Porph. VP: 16). Este, herdeiro de um célebre pirata, graças a um exército mercenário, havia tomado Samos em 538 a.C. Com um governo usurpador, havia provocado a emigração forçada de uma parte dos sâmios. A primeira diáspora da qual temos conhecimento é aquela em direção de Diceraquia, na atual região de Nápoles, em 524 a.C (Accame 1980). Apesar de alguma tradição recordar - é o caso de Antístenes (Porph. VP: 7; D. L. Vitae VIII. 3) - uma inicial colaboração entre Pitágoras e Polícrates (o primeiro havia solicitado que o rei do Egito, Amasi, acolhesse o segundo para que pudesse partilhar com ele a formação dos sacerdotes egípcios), a referência a uma tradicional oposição de Pitágoras à tirania, provavelmente já aristoxénica, e, portanto, do IV século a.C, serve como tal para representar a figura de um Pitágoras como "emigrante em busca da liberdade" (Burkert 1972: 119). Pois essa mesma liberdade será o tecido ideológico da refundação das cidades pitagóricas na Magna Grécia.

${ }^{48}$ Orig.: "There is no inconsistency between this [political] and the religious and ritual side of Pythagoreanism. In fact, cult society and political club are in origin virtually identical. Every organized group expresses itself in terms of a common worship, and every cult society is active politically as a hetairía". Mas vejam-se também os argumentos de Zhmud (1992: 247 n5), que discorda dessa interpretação, negando importância à componente religiosa da comunidade pitagórica. Da mesma forma Philip (1966: 138).

${ }^{49}$ Sobre isso cf. também Cornelli (2010). 


\subsection{Acusmáticos E MATEMÁticos}

No interior da própria comunidade pitagórica, a tradição demonstra conhecer aqueles que à primeira vista pareceriam revelar diversos graus de pertença à koinonía. Jâmblico recorda a pretensa divisão entre Pitagoreus, discípulos integrados totalmente à comunidade de vida, de um lado,e Pitagoristas, do outro: estes últimos, êmulos dos primeiros, seguiam os estudos e as doutrinas, mas não obedeciam às prescrições do bios em sua radicalidade (Iambl. VP: 80). O Anônimo de Fócio (Thesleff 1965:237, parágrafos 7-12) conhece um número ainda maior de graus de separação e progressiva pertença à comunidade: veneráveis, dedicados aos estudos teoréticos; políticos, que se ocupavam da gestão da vida humana; matemáticos, estudiosos da geometria e astronomia; pitagóricos, discípulos diretos de Pitágoras; pitagoreus, por sua vez discípulos destes últimos; e pitagoristas, simpatizantes, não membros da comunidade.

Contudo, a distinção mais comum na literatura pitagórica, constantemente retomada pela crítica contemporânea sobre o pitagorismo, é aquela entre acusmáticos e matemáticos. Em geral, a distinção entre os dois grupos corresponde ao esquema da separação entre, de um lado, o homem de ciência, como seria o caso do mathematikós, que se dedica aos estudos e à pesquisa geométrica, astronômica, musical; e, do outro, o homem de fé, no caso do akousmatikós, que se limitaria a seguir os akoúsmata e sýmbola que regulamentam a vida pitagórica..$^{50}$

Todavia, todas as distinções de graus de pertença no interior da comunidade pitagórica, incluindo esta última, encontram-se somente em fontes tardias. De fato, a primeira referência à distinção entre acusmáticos e matemáticos aparece somente no século II C, em Clemente Alexandrino (Stromata 5.59), e depois em Porfírio (VP: 37) e em Jâmblico (VP: 81, 87-88, De Comm. Mathem.76, 16s).

Além disso, a tradição dessa distinção carrega diversos problemas historiográficos. Primeiramente, o termo akoúsma não é encontrado, no sentido de preceito a ser seguido, antes de Jâmblico. Até Porfírio, os preceitos da vida pitagórica são chamados de sýmbola. ${ }^{51}$ Por consequência, o uso do termo acusmáticos deverá ser atribuído ao próprio Jâmblico e não poderá ser considerado como uma válida designação de um grupo real, historicamente presente à época dos primeiros pitagóricos. A mesma impossibilidade é sugerida pela própria errática complexidade das prescrições às quais um pitagórico deveria prestar atenção, caso quisesse seguir o conjunto dos akouismata. Segundo um testemunho de Jâmblico (VP: 82), haveria akouismata de três tipos, cada um respondendo a uma pergunta: tí ésti, o que é, ti málista, o que é maior, e tí prákteon, o que se deve fazer:

\footnotetext{
${ }^{50}$ A referida interpretação da distinção dos dois como entre o homem de ciência e o homem de fé é de Centrone (1996: 81).

${ }^{51} \mathrm{O}$ próprio Jâmblico utiliza sýmbola até o Protreptico. Cf. Zhmud (1992: 248 n15) para as referências das passagens de Aristóteles a Porfírio.
} 
Todos os assim chamados akoúsmata dividem-se em três grupos: os do primeiro indicam o que é algo; aqueles do segundo, o que é maior; aqueles do terceiro, o que se deve e não se deve fazer. Aqueles que definem o que é determinada coisa são deste tipo: "O que são as ilhas dos bem-aventurados? São o Sol e a Lua. O que é o oráculo de Delfos? A tétrada, isto é, a harmonia, na qual estão as sereias". Ao grupo que indica o que é maior, pertencem os seguintes exemplos: "O que é a coisa mais justa? Sacrificar. Qual a mais sábia? O número, mas imediatamente depois vem o que deu o nome às coisas. Qual a mais bela? A harmonia. E a mais forte? O raciocínio. E a melhor? A felicidade. E o que é a coisa mais verdadeira de se dizer? Que os homens são malvados” (Iambl. VP: 82).

O resultado é uma série de prescrições que Zhmud (1992: 241) define, como de costume sem meios termos, "um tremendo conjunto de coisas absurdas" ( $a$ tremendous amount of absurdities). Entre elas, é preciso calçar antes o par direito do sapato, não se devem frequentar as ruas principais, falar sem luz, carregar a imagem de um deus no anel, sacrificar o galo branco. ${ }^{52}$ Segundo Zhmud, é realmente difícil imaginar que, na prática, alguém pudesse seguir esta complexa rede de acusmata.

Em segundo lugar, a principal fonte da separação entre acusmáticos e matemáticos, isto é, Jâmblico, revela uma extraordinária contradição: nas duas vezes em que copia da mesma fonte (Iambl. VP: 81 e 87) acaba por se contradizer. ${ }^{53}$ Enquanto em $V P$ : 81, afirma:

Sua filosofia assumia duas formas, pois os que a praticam encontram-se distintos em dois gêneros: os acusmáticos e os matemáticos. Entre eles, os matemáticos eram reconhecidos pelos outros como pitagoreus, mas de sua parte não consideravam os acusmáticos como tais, não atribuindo a doutrina por eles professada a Pitágoras, mas a Hipaso (Iambl. VP: 81).54

Logo em seguida, no capítulo 87, Jâmblico afirma exatamente o oposto:

Aqueles pitagóricos que se ocupam das matemáticas reconhecem [os acusmáticos] como Pitagóricos. Estes afirmam sê-lo em maior medida e estar professando a verdade (Iambl. VP: 87).

${ }^{52}$ Zhmud chega a sugerir que seja impossível aceitar seriamente estes tabus $(1992,244)$. Todavia, para ampla discussão tendente a compreender o sentido dos akoúsmata como partes da cultura dos rituais mistéricos no mundo antigo, cf. Burkert (1992: 166-192).

${ }^{53}$ Inédita é a contradição que apresentam as duas versões, não certamente o já citado (1.3) procedimento de corte e colagem que, ao contrário, distingue os procedimentos redacionais de Jâmblico em relação a suas fontes. Cf., para isso, em geral, Rohde (1872: 60); e, para a passagem específica, Burkert (1992: 193).

${ }^{54}$ Hipaso parece ter sido o primeiro pitagórico a se ocupar claramente de pesquisas científicas: a ele é atribuída a experiência dos discos de bronze de igual diâmetro e diversa espessura, através dos quais teria compreendido as relações numéricas que presidem as harmonias musicais (Cf. Aristóxeno, Fr. 90 Wehrli). Centrone (1996) sugere que a autoria da acusação a Hipaso da divulgação do segredo poderia ser de âmbito matemático, como tentativa de legitimação das pesquisas matemáticas, fazendo-as remontar ao próprio Pitágoras (1996: 85-86). 
Paralelo a este último é outro testemunho de Jâmblico, presente no $D e$ communi mathematica scientiae (25: 76.16-78.8):

Entre eles, os matemáticos reconheciam como pitagóricos os acusmáticos, enquanto estes não reconheciam como pitagóricos os matemáticos, nem que sua doutrina fosse aquela de Pitágoras - seria, isto sim, de Hipaso. Alguns afirmam que Hipaso teria nascido em Crotona, outros em Metaponto. Os pitagóricos que se ocupam das matemáticas reconhecem que estes [os acusmáticos] são pitagóricos, mas afirmam sê-lo em maior medida e estar professando a verdade (Iambl. De Comm. Mathem. 25, 76.16-78.8).

A contradição é evidente: enquanto na primeira versão os matemáticos seriam os verdadeiros pitagóricos e, por esse motivo, negariam a homología pitagórica aos acusmáticos, na segunda versão (tanto na Vida de Pitágoras como na passagem paralela do De communi mathematica scientia), Jâmblico estaria afirmando o oposto: seriam os acusmáticos a negarem que os matemáticos professam a verdadeira doutrina pitagórica. Com um detalhe especialmente interessante: Hipaso acaba sendo identificado como acusmático na primeira, e matemático na segunda versão.

Essa contradição obriga a um trabalho de reconstrução de uma possível versão original do testemunho. Deubner (Iamblichus, 1937), e em seguida Burkert (1992: 193-208) demonstraram incontestavelmente que seria a segunda, isto é, seriam os acusmáticos a questionar a congruência dos matemáticos à verdadeira pragmatéia de Pitágoras. Não é, de fato, possível imaginar simplesmente uma escorregada de Jâmblico em VP: 81: algo nesta contradição deverá revelar seus motivos. Eles devem ser procurados para além do procedimento desajeitado de corte e colagem de Jâmblico, que se revela na improvável transformação de Hipaso de matemático a acusmático. ${ }^{55} \mathrm{O}$ motivo do erro é que provavelmente Jâmblico não consegue acreditar naquilo que recebe de suas fontes, isto é, que o pitagorismo originário seja aquele professado pelos acusmáticos, pois o que ele conhece do pitagorismo, mediado pela tradição acadêmica e peripatética, é exatamente a preocupação central com os mathémata, conforme se verá em detalhes no capítulo quarto. Burkert imagina o procedimento psicológico-redacional de Jâmblico da seguinte forma:

Parecia-lhe impensável que alguém pudesse contestar isso, para não mencionar o fato de esses descrentes serem reconhecidos por seus adversários como verdadeiros pitagóricos. Jâmblico conhece a tradição pela qual os acusmáticos eram uma classe inferior, os 'espúrios', os 'muitos' que não são os verdadeiros filósofos. Aqui ele só pode acreditar que seus olhos o estão enganando e rapidamente troca os dois nomes. Temos aqui, então, uma alteração arbitrária, cujo motivo é claro; mas não é mantido consistentemente, e o resultado disso é a confusão (Burkert 1972: 194-5). ${ }^{56}$

${ }^{55}$ Para uma análise das passagens em que Jâmblico demonstra análoga superficialidade na leitura das fontes, cf. Von Fritz (1940: 105-107).

${ }^{56}$ Orig.: "It seemed to him unthinkable that anyone could contest this, to say nothing of 
A reconstrução da confusão de Jâmblico e sua troca de nomes leva finalmente àquela que pode ser considerada a hipótese central destas últimas páginas: acusmáticos e matemáticos não seriam, ao contrário da vulgata dos estudos pitagóricos, dois graus distintos de filiação à koinonía, e sim duas correntes, dois grupos no interior do mesmo movimento pitagórico. Os matemáticos representariam o segundo momento de desenvolvimento com relação a um pitagorismo originário, que, ao contrário, seria marcadamente acusmático. Por esse motivo, estariam empenhados em uma luta pela legitimidade, diante da recusa, por parte dos primeiros, de reconhecê-los como portadores da mesma verdade. ${ }^{57}$

Como consequência dessa hipótese, surge obviamente um problema adicional a ser enfrentado e que diz respeito ao momento exato em que teria havido essa divisão, esse cisma. Trata-se, com toda probabilidade, de uma divisão que corresponde a um momento sucessivo do desenvolvimento do pitagorismo, ainda que seja difícil estabelecer quão sucessivo. As tentativas de conectar esse cisma interno com a crise gerada pelas revoltas antipitagóricas de meados do século $\mathrm{V}$ a.C não deram nenhum resultado concreto, ainda que Riedweg (2002: 176) sugira que seja possível pensar em uma maior separação entre os dois grupos após a diáspora que se seguiu às revoltas e o contemporâneo avanço da filosofia natural no fim do século $\mathrm{V}$ e início do século IV a.C. ${ }^{58}$

Apesar da procedência histórica desse cisma ser colocada em sérias dúvidas por Zhmud (1992), os argumentos de Delatte (1915, 273ss.) e, de maneira especial, de Burkert (1972: 196ss.), com relação à existência da possível autoridade de Aristóteles por trás do testemunho (original) de Jâmblico sobre a distinção entre acusmáticos e matemáticos, permitiriam confirmar a tradição da divisão entre os dois grupos. ${ }^{59} \mathrm{Um}$ argumento em favor da antiguidade

these doubters being acknowledged by their opponents as genuine Pythagoreans. Iamblichus knows the tradition that made the acusmatici the lower class, the "spurious", the "many" who are not true philosophers. Here he can only believe that his eyes have deceived him, and quickly switch the two nouns. We have here, then, an arbitrary alteration, whose motive is transparent; but it is not maintained consistently, and the result is confusion".

${ }^{57}$ Por esse motivo, outra é obviamente a genealogia do cisma na versão matemática dele: Pitágoras, por receber diversas lideranças políticas das cidades, teria precisado simplificar sua doutrina, isto é, eliminar de seus ensinamentos públicos as demonstrações científicas, que, ao contrário, reservaria para os mais jovens, desejosos de apreender: os matemáticos derivariam destes últimos (Cf. Iambl. VP: 87-89).

${ }^{58}$ Com ele parece concordar Huffman (2008: 220). Tannery (1887: 85ss.) e Von Friz (1940: $59,92)$, em sentido contrário à reconstrução do testemunho de Jâmblico, chegam a sugerir que possa haver alguma relação entre o cisma da comunidade e as revoltas antipitagóricas de meados do séc. V a.C: baseando-se em Jâmblico (VP: 257ss.) imaginam que a divisão interna da escola, cujo responsável foi Hipaso, teria levado em seguida a uma guerra civil e à crise final. Depois da diáspora que a ela se seguiu, os pitagóricos se teriam retirado à vida religiosa privada. Contra essa hipótese, todavia, está o fato de que os matemáticos continuam ativos depois da crise, como demonstram, entre outros, Filolau e Arquitas.

${ }^{59}$ Veja-se, nesse sentido, também o que foi dito acima (1.4) em relação à posição inaugural de Burnet $(1908,94)$ a esse respeito. Concordam, com Burnet, Delatte e Burkert, Rohde (1871), Minar (1942: 43ss.), Frank (1943: 69ss.), Huffman (1993: 11) e Guthrie (1962: 192ss.), esp.: 
do cisma é que, se fosse muito tardio, já não faria sentido a reivindicação de legimitidade dos matemáticos em uma conjuntura do pitagorismo que, já nos tempos de Timeu, é quase que exclusivamente matemático. ${ }^{60} \mathrm{Um}$ segundo argumento, mais diretamente ligado à hipótese da fonte aristotélica que estaria por trás dele, é que Jâmblico usaria diversas perífrases muito próximas a Aristóteles: uma delas é certamente a frase que introduz o testemunho do De communi mathematica scientia: "duas são as formas da filosofia itálica, que é chamada pitagórica" (Iambl. De Comm. Mathem., 25: 76.16), que encontra paralelos com semelhantes expressões aristotélicas em Metereologica (342b 30) e De Caelo (293a 20).

A tradição parece, enfim, confirmar o que se dizia anteriormente, isto é, que a definição de pitagórico estaria, no começo, mais diretamente ligada à pertença a uma comunidade e à partilha de um bios, constituído principalmente por acusmata e sýmbola, do que propriamente à consonância doutrinária sobre determinadas teorias filosófico-científicas, pois essas mesmas resultariam dos esforços, em boa parte isolados entre eles, de sucessivas gerações de pitagóricos. ${ }^{61}$

Até por esse motivo, não é o caso de enfatizar demasiadamente, na prática, para compreendermos a formação da categoria historiográfica do pitagórico, o pretenso cisma histórico que oporia, de um lado, o homem de fé, do outro, o homem de ciência, conforme os modelos acima citados, pois, mesmo pitagóricos de época já claramente matemática, como seria o caso de Filolau e Arquitas, se perguntados sobre o trópos de seu bios, responderiam provavelmente ser este propriamente o mesmo ouvido de Pitágoras. Isso significa que, até para os pitagóricos das sucessivas gerações, envolvidos mais diretamente na pesquisa científica, é ainda a vida o elemento definidor de sua identidade pitagórica. Todavia, se novamente perguntados sobre quais seriam as características fundamentais desse modo de vida, os pitagóricos dariam provavelmente respostas bastantes vagas (vegetarianismo, simplicidade, pureza em diversos níveis, dedicação aos estudos, pietas) e relativamente incongruentes. De fato, considerando a extensão temporal e permeabilidade cultural da filosofia pitagórica no mundo antigo, é possível concordar com a brilhante comparação de Huffman (1993), que aproxima o pitagórico antigo ao católico atual:

No mundo moderno, podemos dizer que alguém é um católico sem por isso estar completamente claro o que ele pensa sobre uma vasta gama de questões filosóficas. Ser um pitagórico no mundo antigo pode implicar mais em termos de crenças filosóficas do que ser um católico no mundo moderno, mas devemos

\footnotetext{
"the thesis that there were two kinds of Pythagoreans, the one chiefly interested in the pursuit of mathematical philosophy and the other in preserving the religious foundations of the school, is both inherently probable and supported by a certain amount of positive evidence"(1962: 193).

${ }^{60}$ São dessa opinião, entre outros, tanto Burkert (1972: 196) como Centrone (1996: 83).

${ }^{61}$ Em relação ao fato de a corrente matemática dos pitagóricos não se constituir em escola homogênea de pensamento, e, ao contrário, perseguir diferentes doutrinas físicas, cosmológicas e matemáticas, cf. a seguir o que se dirá no capítulo quarto.
} 
ser cuidadosos em assumir que esteja de fato implicado demais (Huffman 1993: 11). ${ }^{62}$

Como no caso do católico, portanto, o pitagórico definir-se-ia menos por uma teologia/filosofia e mais por um sentimento de pertença cultural, por um estilo de vida. Dessa forma, a razão pela qual a tradição consideraria Filolau como pitagórico, enquanto Alcmeão não, repousaria não tanto sobre a diferença doutrinária, mas, sim, sobre o fato de que, enquanto o primeiro teria vivido uma vida pitagórica, o outro não. ${ }^{63}$

É o caso de notar, também, que a contraposição entre acusmáticos e matemáticos acaba-se tornando o leitmotiv da história da crítica, retornando continuamente, quase como um tópos literário, nas hermenêuticas contrapostas de um Pitágoras (e um pitagorismo) científico versus mágico-religioso, por exemplo, ou místico versus político, conforme vimos na primeira parte deste capítulo. As modernas discussões parecem assim continuar nos trilhos de um debate já antigo.

Ao contrário, a proposta de interpretação que subjaz à presente monografia - em sua dimensão sincrônica - é aquela de superar esses esquemas interpretativos dicotômicos, considerando o pitagorismo como uma categoria historiográfica de amplo alcance e pluralidade de atribuições, irredutível aos esquemas troppo estanques da história da filosofia.

Em contrapartida - em sua dimensão diacrônica de categorização do pitagorismo -, a presente obra já reconheceu, com Burkert, que não é possível alcançar nem o Pitágoras histórico, nem o pitagorismo das origens.

De certa forma, o quebra-cabeças ficará sempre inacabado, equivoco, portanto, irreduzível à univocidade de uma única solução hermenêutica das tradições históricas.

${ }^{62}$ Orig.: "In the modern world we may say that someone is a Catholic without therefore being at all clear what he believes on a whole range of philosophical issues. Being a Pythagorean in the ancient world may entail more in terms of philosophical beliefs than being a Catholic does in the modern world, but we should be wary of assuming that too much is entailed".

${ }^{63}$ A questão da relação de Alcmeão com o pitagorismo é espinhosa e continua merecendo certo debate. Em Metafísica A (986), Aristóteles separa Alcmeão dos pitagóricos, mesmo anotando proximidades teóricas entre os dois. Jâmblico (VP: 104) diz que Alcmeão teria sido discípulo e ouvinte do próprio Pitágoras. O mesmo diz Diógenes Laércio (Vitae VIII. 83). Para os comentadores modernos da questão, cf. Timpanaro Cardini $(1958,119)$ e Centrone $(1989$, 116). Cf. também Cornelli (2009a). 


\subsection{Conclusão}

Pode ser útil, antes de passar ao próximo capítulo, refazer o percurso tecido neste segundo capítulo, recuperando as sugestões metodológicas e propostas hermenêuticas aqui desenvolvidas, pois serão colocadas em jogo na análise das duas tradições que mais decididamente contribuíram para a definição da categoria pitagorismo, cada uma delas com suas problemáticas específicas.

O ponto de partida foi a pergunta de Zeller se seria possível uma descrição coerente do complexo fenômeno do pitagorismo. O caminho seguido foi sair em busca da categoria pitagorismo em suas duas dimensões, diacrônica e sincrônica. O objetivo declarado da busca não foi reduzir a complexidade de significados e experiências que a categoria reúne em si. Ao contrário, o objetivo foi verificar como esta teria resistido à previsível diluição de um movimento que, em sua diversidade, estende-se ao longo de mais de mil anos. A especificidade do objeto sugeriu - sob pena de não compreensão do fenômeno - tratamento especial, do ponto de vista metodológico, que assuma conscientemente as características de um caminho interdisciplinar e multifacetado. Por outro lado, apontou-se que a compreensão sincrônica do pitagorismo implica compreendê-lo à luz das categorias pelas quais normalmente descrevemos a filosofia antiga: para isso, declarou-se a necessidade de superar as dicotomias entre ciência e magia, escrita e oralidade, jônicos e itálicos, às quais a historiografia usualmente nos acostumou, pois nenhuma delas, sozinha, parecer dar conta da complexidade da categoria do pitagorismo.

A primeira pergunta que surgiu, quase uma porta de entrada para a definição da categoria do pitagorismo, é certamente aquela sobre a identidade do pitagórico, isto é, sobre quem poderia dizer-se pitagórico no mundo antigo. Os critérios comumente utilizados para definir a questão não pareceram resistir ao crivo metodológico acima anunciado: pois não é possível pensar na escola pitagórica como em algo homogêneo do ponto de vista doutrinário, nem sequer utilizar o critério geográfico ou do discipulado direto, geralmente utilizado pela doxografia. Restou assim reconhecer que o que define o pitagórico é sua adesão a um particular estilo de vida.

Esta conclusão abre imediatamente o problema das modalidades históricas da comunidade pitagórica primitiva, protopitagórica, como detentora, ao menos etiológica e genealogicamente, das prescrições que regulamentam esse estilo de vida. Platão e Aristóteles não são de grande ajuda para compreender qual é a característica saliente dessa comunidade, por revelarem em seus testemunhos uma ambiguidade insuperável entre a imagem de uma escola de pensamento e aquela de uma comunidade de vida, marcada pela ritualidade e o culto.

Até mesmo a comparação sincrônica com os modelos correntes do thíasos e da hetairía não surtiu grande avanço hermenêutico: de certa forma, a comunidade pitagórica é, ao mesmo tempo, as duas coisas e nenhuma delas. A aporía da tradição obrigou a uma mudança de rumo, recolocando a questão em outro piso, tanto metodológico como textual. 
Por esse motivo, seguindo a sugestão de Burkert, procurou-se verificar a adequação das tradições sobre a comunidade pitagórica com o modelo sociológico da seita. Ainda que se prefira a designação mais neutra de comunidade, o exercício de comparação da koinonía pitagórica com a tipologia sociológica que identifica uma seita permitiu articular de forma bastante coerente grande diversidade de características expressas pela literatura que, juntas, compõem um quadro coerente para a categoria pitagorismo. Estas contribuem para a descrição da comunidade pitagórica como um grupo numericamente reduzido, com características elitárias, alternativo aos moldes de sua cultura e mantendo parte das informações sobre sua ideologia sob sigilo; vida em comum, comunhão dos bens, submissão à autoridade de um guia carismático levam a forte sentimento identitário: a philía entre os pitagóricos torna-se proverbial no mundo antigo. Expulsão dos apóstatas, prescrições reprodutivas e intensa mobilidade geográfica garantem a sobrevivência diacrônica da comunidade.

A análise do esquema narrativo da fundação da comunidade pitagórica, tanto em Porfírio como em Jâmblico, confirmou os sinais de uma comunidade que se define, mesmo do ponto de vista político, como alternativa à cidade. Enfim, os diversos graus de pertença à comunidade, aos quais a tradição parece referir-se, especialmente a separação entre matemáticos e acusmáticos, foram revelados, ao contrário, como duas correntes, dois grupos no interior do pitagorismo. A análise das tradições permitiu detectar que os matemáticos representariam um segundo momento de desenvolvimento com relação a um pitagorismo originário, marcadamente acusmático. $\mathrm{O}$ cisma teria acontecido já em época bastante antiga, o que confirmaria, mais uma vez, a hipótese inicial pela qual é ainda o bios, antes que uma unidade doutrinária, a definir a identidade pitagórica.

Duas temáticas contribuíram mais decididamente para a definição da categoria pitagorismo ao longo da história da tradição: metempsicose e matemática. As mesmas serão objeto do capítulo terceiro e do quarto, a seguir. A análise procurará, por um lado, verificar a originalidade das duas temáticas para o protopitagorismo e o pitagorismo do século $\mathrm{V}$ aEC, e por outro lado sinalizar de que maneira essas temáticas contribuíram para a categorização do pitagorismo ao longo da história da tradição. 


\section{Parte III}

IMORTALIDADE DA ALMA E METEMPSICOSE 
Porfírio, em uma passagem já citada no capítulo anterior (2.1) no contexto da discussão sobre os modelos possíveis de comunidade pitagórica, resume aquelas que a tradição passará a considerar como as doutrinas centrais do Pitágoras histórico, notadamente da imortalidade da alma (e de sua transmigração), do eterno retorno e do parentesco universal. É o caso de voltar mais uma vez para ela:

Algumas de suas afirmações ganharam notoriedade praticamente geral: 1) afirma que a alma é imortal; 2) que transmigra em outras espécies de seres vivos; 3) que, periodicamente, o que já aconteceu uma vez volta a acontecer, e nada é absolutamente novo; e 4) que todos os seres animados devem ser considerados como do mesmo gênero. Ao que parece foi mesmo Pitágoras a introduzir pela primeira vez estas crenças na Grécia (Porph. VP: 19).

Esse resumo porfiriano das doutrinas mais célebres de Pitágoras remete imediatamente para o coração da problemática da categorização histórica do pitagorismo. Não se pode fugir do fato de que, no bojo dessas doutrinas apontadas como originárias, não apareça nenhuma referência à matemática ou à teoria astronômica, por exemplo, ou mesmo à cosmologia e à política, que têm, ao contrário, papel fundamental para a definição do pitagorismo em outros estratos da tradição; entre eles, certamente, o estrato que corresponde aos textos aristotélicos.

A referência a pretensas doutrinas originárias do pitagorismo, portanto, coloca em pauta, desde o início, a questão da categorização historiográfica do movimento que estas páginas estão perseguindo: isto é, da grande diversidade de doutrinas e das dificuldades de articulá-las no interior de um sistema filosófico-científico coerente. É ainda a dúvida de Zeller sobre a possibilidade de uma descrição coerente da filosofia pitagórica (Zeller e Mondolfo 1938: 597) a desafiar um percurso por meio das fontes pitagóricas em busca das temáticas que, ao longo da história da tradição sobre o pitagorismo, contribuíram mais diretamente à definição da categoria pitagorismo.

Duas temáticas destacam-se como centrais nesse sentido: a teoria da alma, pressuposta direta ou indiretamente nas quatro afirmações acima citadas, e a matemática, ao contrário grande ausente na passagem acima. Em ambas, a compreensão do valor hermenêutico das questões envolvidas passará por articulação das duas dimensões historiográficas acenadas no capítulo anterior, isto é, da dimensão diacrônica e da sincrônica.

Ainda que resumo de época tardia, a passagem de Porfírio é certamente excelente porta de entrada para a discussão das tradições que o terceiro e o quarto capítulo, que aqui iniciam, e a que se propõem. Se não por outros motivos, ao menos porque a tradição remonta provavelmente já ao pupilo 
de Aristóteles, Dicearco. ${ }^{1}$ Não é acaso, de fato, que diversos comentadores já clássicos se deram conta da importância dessa passagem para reposicionar teoreticamente as origens da filosofia pitagórica em estreita conexão com as temáticas ético-religiosas. ${ }^{2}$ As sugestões de Porfírio nortearão, portanto, a busca da compreensão de um núcleo teórico que corresponde ao Pitágoras histórico e ao protopitagorismo, ainda que cientes de que esta mesma tradição porfiriana está longe de representar a solução de um problema historiográfico. Ao contrário, é provavelmente o começo dele. E como tal será enfrentado nas páginas a seguir.

A primeira doutrina citada por Porfírio (VP: 19), aquela da transmigração da alma,é ligada a uma tradição amplamente documentada sobre a competência de Pitágoras para assuntos ligados ao além-túmulo: trata-se de tradições que estão inseridas no modelo de sabedoria arcaico que Betegh (2006) definiu acertadamente como journey model (modelo de viagem). O sapiente filósofo adquire conhecimento por meio de itinerário que o leva a percorrer tempos e espaços distantes ou impraticáveis ao restante dos mortais, incluindo nestes também - ou, melhor, especialmente - o mundo do além-túmulo. ${ }^{3}$

Essa transmigração da alma foi chamada no mundo grego de metempsicose. O termo metempsychósis não revela especiais problemas de tradução: desde a Índia até a Grécia, remete ao mover-se (ação indicada comumente pelo termo "transmigração") de uma alma de um corpo para outro. O mover-se desenha idealmente um kiklos, um ciclo, ou círculo, de nascimento-morte-nascimento. ${ }^{4}$

É certamente o caso de notar que, todavia, não existe, ao menos até o final da época clássica, precisão terminológica na indicação desse ciclo da imortalidade da alma. Conforme veremos, diversas expressões e imagens são utilizadas para indicar esta transmigração: desde vestir, cobrir (Empédocles),

${ }^{1}$ Burkert (1972: 122-123), apesar da resistência por parte tanto de Rathmann (1933: 3ss.) como de Wehrli, que não acolhe o capítulo 19 de Porfírio em seu volume dedicado a Dicearco (Wehrli 1944), segue a tradição desta atribuição que conta com a anuência de Rohde (1871:566), Burnet (1908: 92), Lévy (1926: 50), Zeller e Mondolfo (1938: 314). E acrescenta argumentos francamente convincentes, fundamentados no tom cético que a passagem deixa transparecer e que não pode certamente ser atribuído ao crente Porfírio: deverá ser mais plausivelmente criação de Dicearco, cético pupilo de Aristóteles, que em outros fragmentos revela o mesmo ceticismo e ironia: este afirma, por exemplo, que alma seria uma simples palavra (fr. 7 Wehrli) e que Pitágoras teria sido, no passado, uma bela cortesã (fr. 36 Wehrli).

${ }^{2}$ Cf. para isso De Vogel (1964: 16) e Guthrie (1962: 186); e, mais em geral, o que foi dito acima (1.5).

${ }^{3}$ Nossa investigação não permite aprofundar essa temática da viagem para a construção da sabedoria arcaica. É certamente o caso de remeter para a discussão de Betegh (2006) para a formulação do modelo; assim como a dois estudos recentes que desenvolvem uma particularidade

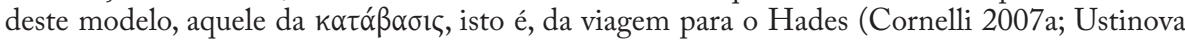

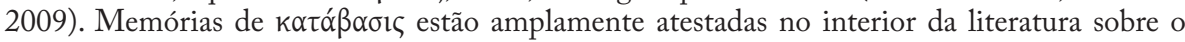
pitagorismo. Entre elas, certamente, a história do trácio Zalmoxis, narrada por Heródoto (IV, 94-95), que teria sido discípulo de Pitágoras, como se verá a seguir.

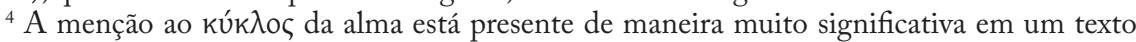
da literatura órfica antiga. A terceira lâmina de ouro órfica de Thurii (fr. 32c Kern, 4 A 65 Colli, II B1 Pugliese Carratelli) assim reza: "voei longe do círculo doloroso que provoca grave inquietação”. Agora também em Tortorelli Ghidini (2006: 74-75). 
penetrar de uma alma no corpo (Heródoto) até o nascer de novo, expresso pelo termo palingênese (pálin gígnesthai) de Platão. ${ }^{5}$

Ainda que o termo metempsychósis apareça pela primeira vez somente no primeiro século EC, com Diodoro Sículo $(\mathrm{X}, 6,1)$, e desde logo referido a Pitágoras, a própria etimologia aponta para origem bem mais antiga do termo: de fato - diferentemente do que se pensou tanto na antiguidade como entre muitos dos comentadores contemporâneos - a etimologia da palavra não indica a "entrada" de algo na alma; nem sequer deriva diretamente do termo psyché. Ao contrário, conforme anota com razão Casadio:

Formou-se a partir do verbo empsychoo, "animar"(que por sua vez está conectado, através de empsychos e psyche ao verbo psycho, "soprar"), ao qual foi acrescentado o prevérbio meta (lat. trans) que denota não somente a mudança, mas também a sucessão ou repetição, e o sufixo sis, denotando a ação abstrata (1991: 122-123). ${ }^{6}$

O campo semântico da metempsicose, portanto, em suas origens e mesmo em seu uso sucessivo, denota a ideia de um soprar novamente a alma para dentro de um corpo. O ciclo é assim concebido como uma série de novas inalações da alma-vida, imagem, esta, que remete àquela do pneûma no interior de um corpo e é claramente dependente, portanto, da concepção física jônica de aer. Como revela o fr. 2 de Anaxímenes, que articula os três termos, psyché,pneûma e aer na mesma frase: "como - dizem - nossa alma, que é ar, nos mantém juntos, assim o ar e o sopro mantêm junto o inteiro cosmo" (13 B2 DK). Sinal forte este da continuidade, ao menos em relação à semântica da metempsicose, com as concepções mais antigas da alma-sopro-vida. ${ }^{7}$

O que mais importa, todavia, a esta investigação, é que a tradição desde muito cedo aproxima a teoria da transmigração à figura de Pitágoras, como veremos a seguir. Sobre isso, até os dias atuais, conforme ficará claro a seguir, "ferve sempre viva a discussão" (Zeller e Mondolfo 1938: 560), já nas palavras de Mondolfo.

${ }^{5} \mathrm{Cf}$. abaixo para as referências.

${ }^{6}$ Orig.: "si è formato a partire dalo verbo empsychoo, 'animare' (che a sua volta è collegato, attraverso empsychos e psyche al verbo psycho, 'soffiare'), cui è stato aggiunto il preverbio meta (lat. trans) denotante non solo il cambiamento ma anche la successione o ripetizione e il suffissale -sis denotante l'azione astratta". Cf. para os antigos especialmente Olimpiodoro (in Phaed: 135 Westerink). Para os contemporâneos Kerényi (1950: 24) e Von Fritz (1957: 89 n1).

${ }^{7}$ Cf. para esta continuidade as observações de Casadio (1991: 142) e Bernabé (2004: 76-78). 


\section{1 "É A ALMA"? (XENÓfANES)}

A crença de Pitágoras neste movimento da alma é testemunhada no célebre fragmento, praticamente contemporâneo a Pitágoras, de Xenófanes:

E conta-se que passava [Pitágoras] ao ser castigado um cachorrinho; sentiu piedade e pronunciou as seguintes palavras: "Para de bater. Pois é a alma de um amigo meu, que reconheci ao ouvir os seus gemidos" (21 B7 DK = D. L. Vitae VIII. 36).

O fragmento é provavelmente a tradição mais antiga que possuímos sobre Pitágoras. Apesar de algumas poucas tentativas tendentes a negar a identificação de Pitágoras como autor do dito citado no fragmento, no contexto de um posicionamento cético generalizado em relação ao fato de a metempsicose poder ser considerada como doutrina pitagórica originária (Kern 1888: 499; Rathmann 1933:37-38; Maddalena 1954: 335; Casertano, 1987: 19ss.), há hoje amplo consenso sobre a referência da personagem citada por Xenófanes como Pitágoras, a começar por Zeller (1938: 314), Burnet (1908: 120ss.), Rostagni (1982: 55), Long (1948: 17), Dodds (1951: 143 n55), Timpanaro Cardini (1958-62) até os trabalhos mais recentes de Burkert (1972: 120s), Huffman (1993: 331), Centrone (1996: 54), Kahn (2011: 11) e Riedweg (2002: 104). ${ }^{8}$

Os argumentos de Maddalena contra a atribuição da doutrina a Pitágoras revelam, quase que pelo avesso, os motivos de sua quase certa atribuição. Ao afirmar que "o fato que a citação da passagem de Xenófanes dependa provavelmente de uma fonte antipitagórica torna ainda mais inadequada a presunção da segura atribuição" (Maddalena 1954: 336), ${ }^{9}$ Maddalena revela, de certa maneira, não ter compreendido o jogo irônico da memória. Ao contrário de Burnet (1908), quando afirma: "torna-se praticamente certo que se trata de Pitágoras, quando encontramos Xenófanes negando isso" (1908: 120). ${ }^{10}$ Pois é exatamente a zombaria, que revela uma intenção antipitagórica na fonte de Xenófanes, a confirmar a importância dada à teoria da metempsicose como elemento identificador do Pitágoras histórico. Como no caso paralelo dos fragmentos polêmicos de Heráclito, conforme se verá em seguida, o fato de o testemunho ser originário de ambientes contrários, e não pitagóricos, só faz aumentar seu valor como testemunho confiável. Pois não seria compreensível

${ }^{8}$ Cf. Casadio (1991: 119-123) para a argumentação sobre a oportunidade de usar o termo metempsicose, no lugar de metemsomatose, para indicar a doutrina da transmigração da alma. Em resumo, o segundo termo seria atestado mais precisamente somente a partir do século II a.C, com Celso e Clemente Alexandrino, e traduziria mais a ideia da reincorporação do que aquela da reencarnação; o uso desse termo, preferido pelo platonismo tardio (é certamente o caso da escola de Plotino), trai uma preocupação e uma tendência antissomática.

${ }_{9}$ Orig.: "il fatto che la citazione del passo di Senofane è molto probabilmente dovuta a uno scrittore antipitagorico rende ancor più inadeguata la presunzione della certa attribuizione".

${ }^{10}$ Orig.: "becomes practically certain that it was that of Pythagoras, when we find that Xenophanes denied it”. 
o porquê de a tradição da literatura pitagórica manter esta memória, não certamente simpática ao movimento, se esta não constituísse minimamente uma referência antiga a um dos pilares de sua doutrina, isto é, a imortalidade da alma (Cornelli 2003a: 203). ${ }^{11}$

Ao olhar o testemunho xenofânico em seu contexto, de uma traditio no interior das Vidas de Diógenes Laércio, é possível notar como a passagem aparece bem no meio de uma série de escárnios a Pitágoras e suas doutrinas. A citação do fragmento de Xenófanes é, de fato, precedida por um testemunho atribuído a Timão de Fliunte, que, nas próprias palavras de Diógenes Laércio, move críticas literalmente mordazes (o verbo utilizado é mesmo dákno, morder) a Pitágoras: "Pitágoras, que tende a usar encantamentos para caçar homens, cheio de palavras majestosas" (D. L. Vitae VIII. 36). À passagem xenofaneia, segue-se imediatamente depois uma crítica do comediógrafo Crátino, que dedica aos pitagóricos, nos Tarentinos, alguns versos cujo interesse historiográfico, apesar de grande, supera o âmbito próprio desta análise. $\mathrm{O}$ comediógrafo ateniense os apresenta de fato como hábeis sofistas:

Eles têm o costume, se alguma vez encontram alguém inexperiente, de fazer-lhe um exame completo da força de seus raciocínios, confundindo-o e arrasando-o com argumentos, definições, antíteses, equações e grandezas, com grande exibição de inteligência (D. L. Vitae VIII. 37). ${ }^{12}$

O mesmo Diógenes Laércio atesta, em outra passagem, as intenções polêmicas de Xenófanes contra Pitágoras. ${ }^{13} \mathrm{~A}$ confirmação de que se trata mesmo de Pitágoras, a expressão kai póte ("e outra vez...") no início dela sugere que outros testemunhos sobre Pitágoras teriam sido relatados anteriormente por Xenófanes, ainda que Diógenes Laércio não os tenha relacionado.

No entanto um detalhe torna o fragmento ainda mais interessante a esta investigação. Apesar de representar provavelmente a mais antiga referência à teoria da metempsicose de Pitágoras, o texto revela também de imediato grave

${ }^{11}$ É significativo que, em uma passagem das obras perdidas de Aristóteles - com toda probabilidade de seu Sobre os pitagóricos -, seja preservada uma anedota paralela, pela qual Pitágoras teria reconhecido, no cadáver de Milias de Crotona, a alma recém-reencarnada do rei Midas (fr. 1 Ross = Iambl. VP 140-143). Nesse caso, todavia, em um contexto distante de qualquer intenção polêmica ou irônica.

${ }_{12} \mathrm{O}$ interesse historiográfico da passagem de Cratino deve ser reconduzido à questão, apenas esboçada no capítulo primeiro (1.6), da ligação entre pitagorismo e primeira sofistica, a partir das sugestões de Rostagni (1922: 149). E este certamente um tópico que mereceria urgente revisão histórica.

${ }^{13}$ D.L. Vitae IX. 18 que lembra, na mesma passagem, de sua crítica também a Tales de Mileto. Xenófanes teria demonstrado ceticismo em relação à célebre memória da previsão do eclipse por Tales (21 B19 DK), criticando a filosofia da natureza de Anaximandro (21 B 27-29, 33 DK; 21 A 47 DK) e significativamente desconfiado de Epimênides (21 B19 DK) e da mântica em geral (21 A52 DK). Portanto, para além da célebre crítica à teologia de Homero e Hesíodo (21 A1 DK), Xenôfanes parece ocupar-se também de expressões religiosas não tradicionais como é o caso de Epimênides e Pitágoras. De fato, como anota corretamente Riedweg (2002: 105), para alguém como Xenófanes, Pitágoras e os pitagóricos, com suas pretensões ético-religiosas, deviam resultar particularmente irritantes. 
dificuldade historiográfica, que sugere cautela em atribuir indiscutivelmente ao Pitágoras histórico e ao protopitagorismo esta mesma doutrina. Notadamente pelo uso do termo central desta discussão, isto é, o termo psyché, no caso atribuído ao cachorrinho. Tanto Burkert (1972: 134: n77) como Huffman (1988; 1993: 331) anotam com razão que o testemunho de Xenófanes não atribui propriamente uma alma ao cachorrinho, e sim afirmaria que o cachorrinho "seria" (esti) a alma de um amigo. Este detalhe aparentemente mínimo é, em verdade, o sintoma de um problema mais profundo, certamente não simples de ser resolvido: qual teria sido a real concepção protopitagórica da imortalidade da alma, isto é, professada por Pitágoras e seus primeiros discípulos?

O caminho de resolução da questão passa certamente por uma análise do próprio termo psyché, conforme aparece no testemunho de Xenófanes. Ainda que o fragmento possa provar a relação de Pitágoras com as teorias da metempsicose, não é certamente razoável pensar que o termo em si possa constituir achado arqueológico dos pretensos ipsissima verba de Pitágoras ${ }^{14}$ Isto é, nada indica que a expressão estí psyché ("seria a alma") possa ser considerada como um fragmento de Pitágoras. A prova disso, o mesmo Empédocles, ele próprio pensador da imortalidade da alma, e também de âmbito pitagórico, ${ }^{15}$ ainda não utiliza o termo psyché em suas teorias da imortalidade, e sim o termo daimones (31 B115 DK). ${ }^{16}$

A primeira fonte pitagórica escrita a utilizar o termo psyché é Filolau, em seu fr. 13:

E quatro são os princípios do animal racional, como também Filolau diz em Sobre a natureza: cérebro, coração, umbigo e genitálias. A cabeça da mente, o coração da alma e da sensação, o umbigo do enraizamento e crescimento primitivo, as genitálias da jogada da semente e da geração. E o cérebro é o princípio do ser humano, o coração do animal, o umbigo da planta e as genitálias de todas as coisas juntas: pois da semente brotam e crescem (44 B13 DK)..$^{17}$

O coração é aqui dito arché da psyché e dos sentidos, portanto. No entanto, o fragmento de Filolau, no lugar de resolver a questão, parece complicá-la ainda mais. Pois aqui alma é indiscutivelmente uma realidade que diz respeito aos fenômenos da vida animal, e não algo que possa ser pensado como imortal. Por esse motivo, Burkert (1972: 270), seguido por Huffman (1993: 312) propõe que a tradução mais correta deva ser simplesmente vida, por tratar-se, neste caso, de um uso pré-platônico do termo psyché, que não quer indicar o complexo de faculdades psíquicas da forma que irá significar mais tarde.

${ }^{14}$ Cf. Huffman (1993: 331): "it seems perverse to seize upon the second-hand satirical remarks of Xenophanes and use it as the basis on which to reconstruct the Pythagorean doctrine of psyche".

${ }^{15}$ Como afirma Kingsley (1995), mas já antes o mesmo Burkert (1972: 57 n. 26).

${ }^{16}$ Cf. para isso Dodds (1951: 174s), Guthrie (1962: 319), Philip (1966: 157-158). Para uma resenha do uso pré-socrático do termo cf. Balaudé (2002).

17 Em favor da autenticidade do fragmento, amplamente discutida, cf. a argumentação mais recente de Huffman (1993: 307). 
Esta mesma acepção do termo é confirmada por um testemunho aristotélico que significativamente aproxima a teoria da alma pitagórica com aquela de Demócrito:

O que dizem os pitagóricos parece seguir o mesmo raciocínio [dos atomistas], pois alguns deles declaram que a alma são as poeiras no ar; outros, por sua vez, que ela é o que faz com que se movam (De an. 404a16). ${ }^{18}$

Já foi anotado anteriormente que é bastante plausível que, quando Aristóteles fala indistintamente de pitagóricos, esteja de fato pensando no pitagorismo do século $\mathrm{V}$ a.C, e mais propriamente em Filolau (cf. 1.1). O âmbito semântico da psyché pitagórica seria, portanto, aquele do movimento dos seres animados; e com uma conotação marcadamente materialista: a alma seria um amontoado de elementos minúsculos (xúsmata, poeiras), sempre em movimento, localizados no coração. A teoria da harmonía que é pressuposta a todo elemento material, pensada por Filolau como acordo de limitantes e ilimitados (44 B1 DK), revela as formas desse movimento, que seguirão, portanto, como todas as realidades, padrões rigorosamente harmônicos. ${ }^{19}$

No entanto, essa teoria da psychécomo harmonia e composição de elementos materiais é evidentemente contraditória com aquela de sua imortalidade..$^{20}$ Como conciliá-la, portanto, com a memória acima de Porfírio (VP: 19) pela qual a doutrina da metempsicose seria uma das doutrinas mais célebres de Pitágoras, e com o fragmento de Xenófanes, pelo qual o próprio Pitágoras teria demonstrado pensar na imortalidade da alma e em suas transmigrações?

Imaginar que Filolau não devia acreditar na imortalidade da alma, como sugere Wilamowitz (1920: II 90), é só aparentemente lectio facilior. ${ }^{21}$

${ }^{18}$ A tradução é de Maria Cecília Gomes dos Reis (Aristóteles 2006). Deve-se notar que a comparação entre os dois movimentos (pitagorismo e atomismo) é sublinhada pelo texto tradito de Ross com a inserção da qualificação esféricos ( $\tau \dot{\alpha} \sigma \varphi \alpha \iota p o \varepsilon ı \delta \tilde{\eta})$, atribuída aos átomos/poeira, na linha 2 a 4 de 404a. Diels propõe emenda desta, por considerá-la uma glosa daquilo que é depois dito dos pitagóricos na linha 16 e seguintes, na passagem (67 A28 DK) aqui em pauta.

${ }^{19}$ Não é o caso de subestimar um significativo ponto de conexão entre a concepção

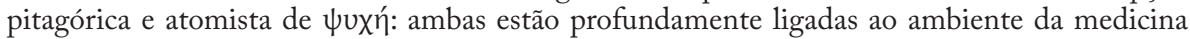
antiga. Burkert e Huffman falam, respectivamente, de medical mileu (Burkert 1972: 272) e medical background (Huffman 1993: 329) como estando por trás de ambos; Gemelli chega a postular não haver distinções entre filosofia e medicina até a terceira parte do século $\mathrm{V}$ a.C: keine Grenzen (Gemelli 2007). Certamente há profunda influência sobre a concepção da $\psi u x n ́$

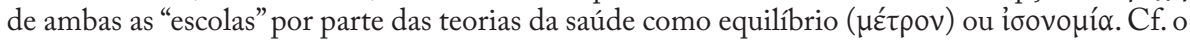
uso destes termos por Alcmeão (24 B4 DK), como também Peixoto (2009) e Cornelli (2009a).

${ }^{20}$ A ideia de Drosdek (2007: 66), pela qual o estágio final das reencarnações seria a harmonia, não passa de uma conjectura, como o próprio autor admite ("We can only guess an answer. And the answer is harmony"), sem bases filológicas para sua sustentação.

${ }^{21}$ Esta mesma doutrina é defendida por Platão no Fédon (85) por intermédio de Símias. Já Zeller e Mondolfo (1938: 563) e Cornford (1922) perceberam que, na verdade esta mesma contradição não deveria ter sido percebida como tal pelos pitagóricos do V século a.C. Seja porque a harmonia se referiria somente às partes da alma, e não aos seus elementos corpóreos (Rohde 1920), ou exclusivamente à parte da alma destinada à morte junto como o corpo (Rostagni 1982). A ampla discussão da questão por Guthrie (1964: 308-319) conecta a questão 
Pelos critérios desenvolvidos ao longo do capítulo segundo sobre a questão da identidade do pitagórico, que se dizia então estar ligada mais a um estilo de vida do que a uma coerência doutrinária, seria realmente muito difícil imaginar que Filolau não acreditasse na metempsicose. Pois essa mesma teoria é pressuposto de muita parte da ritualidade e da mitologia (e filosofia) pitagóricas, e Filolau teria tido muita dificuldade para ser identificado como pitagórico sem que professasse de alguma maneira essa teoria. Ao contrário, seria mais fácil imaginar que Filolau pensasse, sim, na imortalidade da alma, mas, como é o caso de Empédocles acima, utilizasse outra terminologia que não psyché para indicar essa parcela imortal do indivíduo.

Tratar-se-ia, portanto, no caso do pitagorismo pré-platônico, da coexistência de duas noções diferentes de alma, no resumo que Guthrie faz da questão (1964):

Duas diferentes noções de alma, portanto, existiam na crença daquele tempo, a psyché que 'esvaecia como fumaça' ao morrer, e que os escritores de medicina (incluindo sem dúvida alguns céticos e pitagóricos hereges) racionalizaram na harmonia dos opostos físicos que dão origem ao corpo; e o mais misterioso daimon no homem, imortal, e que sofre transmigração através de vários corpos, mas que em sua essência mais pura é divino. Isto também pode ser chamado psyché, e o é em Platão. Ambas sobrevivem lado a lado no pensamento religioso geral corrente, e ambas sobrevivem na curiosa combinação de filosofia matemática e misticismo religioso do qual é feito o pitagorismo (1964: 119). ${ }^{22}$

É certamente o caso, portanto, a partir desta introdução às questões historiográficas ligadas à teoria da alma pitagórica, de recolher provisoriamente duas sugestões hermenêuticas, a serem desenvolvidas ao longo das próximas páginas.

Em primeiro lugar, Pitágoras e seu movimento elaboraram com toda probabilidade uma teoria da imortalidade da alma que tem em sua metempsicose um dos elementos-chave. Essa elaboração parece ser reconhecida pelas fontes antigas, como será visto com mais detalhes a seguir, como um dos traços mais característicos do pensamento sobre a alma na antiguidade. $\mathrm{O}$ reconhecimento

à harmonia cósmica, enquanto Philip (1966: 163ss.) sugere que a concepção da alma como

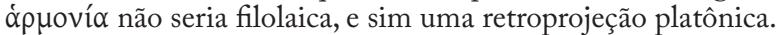

${ }^{22}$ Orig.: "Two different notions of soul, then, existed in contemporary belief, the psyché which 'vanished like smoke' at death, and which medical writers (including no doubt some sceptical and therefore heretical Pythagoreans) rationalized into a harmonia of the physical opposites that made up the body; and the more mysterious daímon in man, immortal, suffering transmigration through many bodies, but in its pure essence divine. This too could be called psyché as it was by Plato. Both survived side by side in the general current of religious thought, and both also survived in the curious combination of mathematical philosophy and religious mysticism which made up Pythagoreanism". Da mesma forma parecem compreender, metodologicamente, a questão da coexistência de diversas teorias da alma ao longo do desenvolvimento do pitagorismo Zeller e Mondolfo (1938: 563): "[nel pitagorismo] le concezioni vecchie paion continuare a sussistere accanto alle nuove, non che ad altri svolgimenti collaterali, pur derivati dall'unione di elementi preesistenti”. 
dessa atribuição não implica, todavia, a afirmação pela qual a teoria pitagórica da alma constitua um sistema articulado e dogmático de crenças, uma doutrina coerente. É possível concordar, nesse sentido, com as observações de cunho antropológico de Burkert, quando afirma que:

Concepções do além-túmulo são e sempre foram sincréticas. É somente a teologia, que dá as caras mais tarde na tradição, a interessar-se por nivelar as diferenças. [...] Somente um dogma sem vida é preservado sem mudanças; ao contrário, uma doutrina levada a sério é continuamente revisada ao longo de um processo contínuo de reinterpretação (Burkert 1972: 135). ${ }^{23}$

Dessa forma, toda coerência da qual o objeto precisa será aquela do estilo de vida que dessa crença ético-religiosa deriva, isto é, do lado acusmático do bios, nos moldes daquilo que se acenava acima em relação a Filolau e sua concepção da alma.

Em segundo lugar, o testemunho de Xenófanes, com seu uso extemporâneo do termo psyché, aponta para a necessidade de verificar em que medida a história da tradição apropria-se das teorias pitagóricas da imortalidade da alma, com seu léxico próprio e suas imagens míticas associadas, para construir uma categoria historiográfica que dialogue em cada um dos momentos históricos dessa transmissão.

As páginas a seguir serão tecidas a partir dessas duas sugestões acima. De um lado, por meio da busca por um conjunto doutrinário que corresponda a uma teoria da alma protopitagórica; por outro lado, acompanhando a construção da categoria do pitagorismo a partir de sua teoria da imortalidade da alma.

${ }^{23}$ Orig.: "Conceptions of the afterlife are and have always been syncretistic. It is only theology, corning along rather late in the tradition, that is interested in smoothing out the differences. [...] Only dead dogma is preserved without change; doctrine taken seriously is always being revised in the continuous process of reinterpretation". 


\section{2 “SÁbio mais do QUE TOdos”(Heráclito E Íon dE Quios)}

A começar por outro fragmento, atribuído a Íon de Quios, que, em versos elegíacos dedicados a Ferécides, nomeia da seguinte maneira Pitágoras:

Assim ele [Ferécides], insigne pela alma viril e pela dignidade mesmo falecido, goza com a alma de uma vida bem-aventurada se realmente Pitágoras, o sábio, mais do que todos havia compreendido as disposições mentais dos homens (36 B4 DK). ${ }^{24}$

Certa dificuldade de compreender a relação aqui estabelecida entre Pitágoras e Ferécides depende provavelmente do fato de que o contexto integral da citação foi perdido. É possível todavia conjecturar, como fazem Kranz (1934: 104) e Riedweg (2002: 110), que a conexão entre Ferécides e Pitágoras, no contexto de uma vida bem-aventurada além-túmulo, esteja ligada, de um lado, à avaliação geral pela qual Ferécides teria levado uma vida altamente moral, que consequentemente mereceu uma retribuição bem-aventurada, do outro lado, à renomada sabedoria de Pitágoras sobre assuntos como esses, isto é, às suas célebres teorias da imortalidade da alma.

Um argumento parece corroborar esta leitura: o mesmo Íon refere-se, em outro fragmento, a Pitágoras como o autor de alguns dos poemas órficos: "Íon de Quios, nos Triagmas, diz que Pitágoras atribuiu a Orfeu alguns poemas por ele escritos" (36 B2 DK). É este certamente o testemunho mais antigo da relação de Pitágoras com o orfismo. Ver-se-ão, em seguida, mais aprofundadamente, as consequências dessa relação para a compreensão da teoria da imortalidade da alma no pitagorismo. Há, de fato, imediatamente outro detalhe no fr. 4 de Íon que não pode passar despercebido: a expressão sophós perí pánton anthrópon, "sábio mais do que todos os homens", ecoa imediatamente o célebre fragmento 129 de Heráclito. ${ }^{25}$ A referência teria tom polêmico, como a querer corrigir o tiro de Heráclito que nos dois fragmentos que avaliaremos logo mais refere-se a Pitágoras sempre de maneira sarcástica.

Heráclito é, sem dúvida, outra fonte essencial para a compreensão do lugar intelectual de Pitágoras em seu tempo. O diálogo de Íon com o testemunho heraclítico pode, de fato, jogar uma luz toda especial sobre o sentido de sua crítica dirigida contra Pitágoras.

${ }^{24}$ Acolhe-se aqui para o v.3 a emenda de Sandbach (1958/59), que introduz uma ideia importante na citação como aquela do conhecimento que Pitágoras possui, conforme veremos, da história psicológica do indivíduo.

${ }^{25}$ Cf. 22 B129 DK. Não passou de fato despercebido. Cf. Kranz (1934: 227), pelo qual esta referência a Heráclito seria prova da autenticidade desse fragmento de Íon; mas também Zeller e Mondolfo (1938: 317s), Timpanaro Cardini (1958-62: I, 20), Burkert (1972: 123 n13), Riedweg (2002: 110-111), entre outros. 
Heráclito, no contexto de uma crítica ampla e irrestrita dirigida às autoridades intelectuais de seu tempo, notadamente Homero e Hesíodo, lança suas proverbiais flechas contra o próprio Pitágoras, identificado já como um dos mais importantes intelectuais de seu tempo:

Pitágoras, filho de Mnesarco, praticou a pesquisa mais de qualquer um e, tendo feito uma escolha desses textos, com isso conseguiu sua própria sabedoria, que é vária erudição, charlatanaria (22 B $129 \mathrm{DK})$.

A historíe é a pesquisa científica da escola iônica, que Heráclito bem conhece. Pitágoras é aqui compreendido como excelente nessa pesquisa. No entanto, essa mesma pesquisa, na qual Pitágoras se sobressaiu em relação a todos os outros e que parece valer-lhe um inédito elogio do próprio Heráclito ("praticou mais de qualquer um") é, ao contrário, compreendida por Heráclito como "multiciência" (polymathía) e como "charlataneria" (kakotecnia), com uma referência ambígua a certos "escritos" aos quais teria feito referência anteriormente, conforme sugeriria o termo taútas. Enquanto a história da crítica tentou adivinhar quais teriam sido esses escritos, o contexto imediato deles pode ser sugerido por outro fragmento crítico em relação a Pitágoras:

Muita erudição não ensina a compreensão. De outra maneira a teria ensinado tanto a Hesíodo como a Pitágoras, e também a Xenófanes e Hecateu (22 B 40 DK).

A proximidade de Hesíodo e Pitágoras no fragmento acima parece indicar que os escritos deste último estariam ligados à literatura que tem como seus primeiros expoentes tanto Hesíodo como Homero. Literatura, esta, que Heráclito, todavia, desdenha. ${ }^{26} \mathrm{Com}$ essas referências, não surpreende que a sabedoria de Pitágoras tenha tido um resultado tão inaceitável. ${ }^{27}$ Outras sugestões levantadas é que seriam, no interior das teorias de uma derivação oriental da doutrina pitagórica, escritos de matemática babilônios, por exemplo, ou quiçá egípcios. ${ }^{28}$

O fragmento de Íon considerado logo acima, conforme se anunciava, pode corroborar uma terceira hipótese de atribuição destas sýngraphai de Pitágoras, pela qual seriam textos de matriz órfica. Ao que parece, com precisas referências textuais, quase citações invertidas, Íon estaria querendo

${ }^{26}$ Cf. 22 B57 e 106 DK para Hesíodo; 22 A22 DK para Homero. Para uma discussão mais

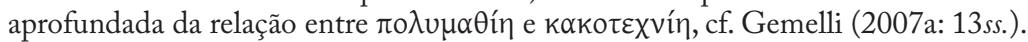

${ }^{27}$ Recentemente, Burkert (1998: 306) sugeriu a possibilidade de esses escritos serem do tipo dos escritos de Ferécides ou até mesmo poemas órficos. Kahn (2001: 17 n32) imaginá-los-ia mais provavelmente como algo intermediário entre os escritos de Anaximandro e de Filolau.

28 A ligação do pitagorismo com o Egito é testemunhada, senão já pelos mesmos estudos matemáticos, pela presença de um templo a Hera com formas arquitetônicas egípcias em Samos, no VI aEC. (Kingsley 1999: 16), assim como por algumas referências a isso do mesmo Heródoto que, em suas considerações sobre os usos sepulcrais dos egípcios (que sepultavam os mortos em vestes de linho e não de lã, como na Grécia), afirma: "Tal [costume] corresponde aos chamados Orfiká e Bakchiká, que na verdade são egípcios e pitagóricos” (Herodt. II, 81). 
defender Pitágoras, agora já em âmbito ateniense, dos ataques que Heráclito havia lançado contra ele. E faria isso, de um lado, identificando esses escritos, conforme se viu no fr. 2, como textos órficos pseudoepigráficos, por outro lado, identificando a historíe com a prática do conhecimento da palingênese das vidas pregressas, isto é, da história psicológica do indivíduo, como a mencionada emenda de Sandbach (1958/59) ao fr. 4 - acima citada - parece sugerir: "havia compreendido as disposições mentais dos homens" (36 B4 DK). A crítica de Heráclito, assim como a defesa de Íon, seriam todas voltadas à forte presença, na sophia de Pitágoras, de teorias da imortalidade da alma de matriz órfica. Ambas constituem, dessa forma, testemunhos preciosos da antiguidade da atribuição dessas doutrinas ao protopitagorismo, senão ao mesmo Pitágoras. ${ }^{29}$

A literatura pitagórica posterior irá identificar essa psicologia genealógica da alma, operada por Pitágoras, como fundamento de sua estratégia clínica: "Pitágoras conhecia suas existências prévias e iniciava a cura dos homens evocando a memória de suas vidas anteriores" (Iambl. VP: 63). A epiméleia pitagórica, portanto, da qual é repleta a tradição sobre Pitágoras, depende, em última análise, de suas capacidades de historiador da alma.

Diversos testemunhos apontam para a fama de suas capacidades de cura: dizia-se entre as cidades que frequentava que ele "não viria para ensinar, e sim para curar". A tradição da cura remonta, provavelmente, a uma expectativa neste sentido reservada para as figuras centrais da filosofia itálica. ${ }^{30}$ Veja-se, de fato, na mesma linha, o que diz Empédocles no prólogo de seu poema das Purificações: "milhares me seguem [...], uns com necessidade de oráculos, outros, há longo tempo tomados por fortes dores desejam ouvir palavras inspiradas que curem doenças de todos os tipos” (31 B112 DK).

Aqui também a cura está ligada a uma especial capacidade oracular, que pode ser aproximada, ainda que não perfeitamente, com a psicologia genealógica da alma de Pitágoras.

${ }^{29}$ Cf. Burkert (1972: 130-131). É interessante notar que já Kranz (1934: 227ss.) defendia que Heráclito devia conhecer esses escritos pitagóricos, sendo nisso seguido por Zeller e Mondolfo (1938), ainda que Mondolfo considere esta hipótese "alquanto ardita" (1938: 318).

${ }^{30}$ Cf. também Nucci (1999) e Macris (2003: 257). 


\section{3 “DeZ ou Vinte gerações humanas” (EMpédocles)}

Como pertencentes a esse mesmo âmbito intelectual e cultural devem ser considerados os testemunhos de Empédocles. Desde a antiguidade, o protagonista de suas Purificaçôes foi identificado com Pitágoras; ${ }^{31} \mathrm{e}$ as influências órficas sobre Empédocles são atualmente consideradas como altamente prováveis. ${ }^{32}$ É inegável que as duas figuras, de Pitágoras e de Empédocles, têm muito em comum: de maneira especial, aproxima-os seu papel dual - nas palavras de Kahn - enquanto ao mesmo tempo filósofos matemáticos e profetas religiosos (Kahn 2001: 16). Ambos são percebidos pelos contemporâneos (e pela literatura sucessiva) como théioi ándres, homens divinos, detentores de poderes e capacidade especiais. É certamente o caso de lembrar, nesse sentido, o fr. 112 de Empédocles: "Eu entre vocês ando como um deus imperecível, não mais mortal, por todos honrado" (31 B112 DK) e os diversos testemunhos sobre a divindade de Pitágoras, entre eles o célebre acusma que responde à pergunta: "Quem é Pitágoras?" com "Apolo Hiperbóreo" (Iambl. VP: 140).

A proximidade de Empédocles com o pitagorismo é comprovada, também, nos fragmentos, por grande quantidade de coincidências doutrinárias. Por esse motivo, de Zeller a Kingsley, chegou-se a imaginar um discipulado direto de Empédocles em relação ao protopitagorismo. As duplas enantiológicas dos fragmentos 122 e 123 lembram de perto a lista de opostos que Aristóteles atribui aos pitagóricos na célebre passagem do primeiro livro da Metafísica (986a). ${ }^{33}$ Como também a concepção cosmológica e antropológica, ambas baseadas no conceito de harmonía, que encontra paralelos nos fragmentos de Filolau e Arquitas; ${ }^{34}$ ou na epistemologia de Empédocles, que, por sua vez conforme o testemunho de Aristóteles no De Anima (404b8 = 31 B109a DK) - estaria fundada no princípio do semelhante que conhece o semelhante. ${ }^{35}$ Segundo o testemunho de Sexto Empírico, o princípio seria certamente já filolaico (44 A29 DK). ${ }^{36}$

${ }^{31}$ Cf. D. L. (Vitae VIII. 54- 56) e os testemunhos de Alcidamantes, Neantes e Timeu neste sentido. Para a crítica moderna: "Who could this be but Pythagoras?" se pergunta Trépanier (2004: 105). Cf. também Doods (1951: 182), Zuntz (1971: 183), Burkert (1972: 109 n65). Mais céticos Zeller e Mondolfo (1958: 329) e, como sempre, Rathmann (1933: 94-131).

${ }^{32}$ Cf. West (1983: 26), Riedweg (1995), Scarpi (2007: 150). Apesar das dúvidas de Trépanier (2004: 106).

33 "Lá estavam a ctônia e a solar de ampla mirada, o ódio sangrento e a harmonia de olhar severo, e a bela e a feia, a ágil e a lerda, a verdadeira amável e a obscura de cabelos pretos” (31 B122 DK). "O nascimento e a dissolução, o sono e a vigília, o móvel e o imóvel, a grandeza rodeada de muitas coroas e miséria, o silente e o vociferante" (31 B123 DK). Cf. para estes fragmentos o elegante comentário de Casertano (2007¹).

${ }_{34}$ Essas referências à harmonia em Empédocles fazem suspeitar que a proposição do conceito de harmonía no interior da história do pitagorismo antecede sua formulação canônica, elaborada por Filolau somente no século V a.C. Cf. Zeller e Mondolfo (1938: 331).

35 "Com a terra, vemos a terra; com a água, a água; com o éter, o éter divino; com o fogo, o fogo arrasador; com o amor, o amor; e a luta, com luta funesta" (31 B109 DK).

${ }^{36} \mathrm{O}$ mesmo critério de conhecimento é lembrado no Timeu de Platão (45c) em relação à criação do ser humano e, in primis, da visão. Um aceso debate tendente, nos últimos anos, a 
No entanto, o fragmento de Empédocles mais imediatamente relevante para essa discussão sobre os testemunhos mais antigos da teoria da imortalidade da alma pitagórica é o fr. 129. Não será preciso acatar a sugestão de Pascal (1904: 141ss.) de que os versos do fr. 129 constituam uma introdução a um discurso do próprio Pitágoras, conforme são citados em Ovídio (Metam. XV 60), pois todas as coincidências doutrinárias acima desenhadas vêm reforçar a compreensão majoritária de que seja mesmo Pitágoras o protagonista do fr. $129: 37$

Havia entre eles um homem de extraordinária visão, que adquiriu uma imensa riqueza de inteligência

e era excelente em uma grande quantidade de sábias atividades.

Quando de fato ele tensionava todas as forças de sua mente

Enxergava facilmente todas as coisas que são, em dez ou vinte gerações humanas (31 B129 DK).

Novamente, os termos da citação, como no caso de Íon acima citado, parecem ecoar as bem conhecidas críticas de Heráclito a Pitágoras, acima citadas. Expressões como extraordinária visão, imensa riqueza de inteligência, grande quantidade de atividades de sabedoria, não são certamente casuais. Há aqui, de fato, uma afirmação da polymathía de Pitágoras. Essa afirmação, diferentemente daquela de Heráclito, não é marcada pelo sarcasmo. Ao contrário. Essa sabedoria especial é qualificada, na segunda parte da citação, de forma muito precisa: toda a visão de Pitágoras é direcionada à palingênese, isto é, ao perscrutar a história da alma em seus movimentos de metempsicose. Tanto a própria como aquela dos outros. Ainda que a referência seja mais genericamente à capacidade de enxergar "todas as coisas que são", incluindo nelas, por exemplo, a capacidade de ouvir a harmonia do universo, no sentido de perceber o som das esferas (Porph. VP: 30), é evidente que o contexto da citação implica mais especificamente a célebre capacidade especial de Pitágoras.

O fr. 129, portanto, no contexto tanto das Purificações como da tradição sobre a figura de Empédocles como homem divino, constitui testemunho da atribuição ao protopitagorismo de uma teoria da alma que pressupõe tanto uma concepção de sua transmigração como uma capacidade especial de Pitágoras de percorrer essa história da alma. ${ }^{38}$

verificar as apropriações dessas teorias do conhecimento no interior daquela que foi em seguida definida como ótica revela um diálogo in fieri, sobre este tema, entre Platão e Aquitas. Cf. para isso Burnyeat (2005) e Huffman (2005: 551-569).

37 Enquanto Rostagni (1982: 232) segue a sugestão de Pascal, para exaustiva relação da história da crítica desta atribuição, cf. Zeller e Mondolfo (1938: 329) e Timpanaro Cardini (1958-62: I, 18). Comentadores mais recentes, entre eles Riedweg (2002), Trépanier (2004) e Gemelli (2007), seguem a tradição, concordando com a mesma atribuição.

${ }^{38}$ A esses argumentos, Philip (1966: 156) acrescenta mais um: os vetos alimentares, que aproximam Empédocles ao pitagorismo, dependem diretamente, a seu ver, da crença na transmigração que ambos partilhariam. 


\subsection{Platão e o orfismo}

O lugar mais generoso de referências e, ao mesmo tempo, mais sensível para a discussão da atribuição das teorias da imortalidade da alma e sua metempsicose ao pitagorismo é certamente a obra de Platão. Todavia, mesmo o testemunho platônico não está isento de problemas e incertezas. A falta de citações diretas do pitagorismo nos textos platônicos dedicados a essas teorias, por exemplo, consolidou desde cedo uma hipótese pela qual elas se refeririam mais propriamente ao orfismo, em vez do pitagorismo. ${ }^{39}$ É obviamente impossível, nesta investigação, esgotar exaustivamente as múltiplas facetas da relação entre Platão e o orfismo, que vai bem além da problemática da imortalidade da alma. ${ }^{40}$ Será o caso de limitar-se aqui a discutir as relações entre pitagorismo e orfismo no interior da problemática da metempsicose, deixando de lado outras possibilidades de abordagem dessa complexa questão, como aquela cosmológica ou política. Contudo, mesmo para as finalidades mais internas à nossa discussão, será preciso fazer continuamente referência à problemática mais geral. ${ }^{41}$

A dificuldade de tecer as relações entre Platão, pitagorismo e orfismo, antes mesmo do que nas sempre lembradas características dialógicas da obra platônica ou nas questões apontadas no capítulo anterior a respeito da tradição e sua categorização do pitagorismo, reside mais imediatamente na incerta determinação do que possa ser considerado orfismo. Em relação, por exemplo, às fontes literárias para esse assunto, é o próprio Platão a revelar a confusão representada pela existência de grande pletora de livros que passavam como obras de Orfeu e Museu (Resp. II, 364e). ${ }^{42}$ A dificuldade representada pela pseudoepigrafia, comum a toda a literatura antiga, torna-se ainda mais dramática no caso de Orfeu. ${ }^{43}$ Por outro lado, já Wilamowitz perguntava se o fato de existirem obras atribuídas a Orfeu implicava necessariamente também a existência histórica de órficos (1932: 192-199). Sua resposta foi negativa e, desde então, a crítica acostumou-se prudentemente a considerar a presença do orfismo no interior da obra platônica como algo indissociavelmente ligado à

${ }^{39}$ Defendem a atribuição das doutrinas ao orfismo Bluck (Plato, 1964: 274-276), Boyancé (1972: 85 n4); e mais recentemente Casadio (1991: 130-131), Centrone (1996: 61).

${ }^{40}$ É certamente o caso de remeter para isso a Bernabé (1998: 2002 e 2011). Cf. também Masaracchia (1993), Brisson (2000b) e Pugliese Carratelli (2001).

${ }^{41} \mathrm{Cf}$. acima para uma discussão historiográfica da questão do orfismo e do pitagorismo (1.8).

${ }^{42}$ A expressão usada por Platão é $\beta i ́ \beta \lambda \omega v$ ő $\mu \alpha \delta o v$ : com o termo ő $\mu \alpha \delta o v$ a indicar mais propriamente tumulto, como aquele dos combatentes em batalha (Cf. Il. IX, 573). Outra memória da grande e confusa literatura atribuída a Orfeu há também no Hipólito de Eurípides ("a fumaça dos muitos escritos", v. 954).

${ }^{43}$ É certamente o caso de recordar a introdução à monografia Orphica de Hermann (1805), um dos primeiros estudiosos modernos do orfismo, que assim começa: "si mea sponte eligendus mibi fuisset scriptor in quo edendo operam meam collocarem, in quemcumque alium facilius quam in Orpheum incidissem" (1805: v). A ele ecoa West (1983: 17), quando afirma que aquele de Orfeu foi o nome favorito pelos poemas pseudoepigráficos de natureza religiosa, metafísica ou esotérica. 
releitura que Platão teve desse movimento; com isso, porém, acabou por ser negada, em princípio, qualquer possibilidade de Platão ser considerado como fonte confiável para o orfismo pré-platônico. ${ }^{44}$ Todavia, recentes descobertas arqueológicas, de maneira especial aquela que trouxe à luz o papiro Derveni, contribuíram para confundir as águas paradas da tradição interpretativa, apontando para clara anterioridade a Platão de temas e referências órficas, cuja existência pré-platônica era normalmente colocada em dúvida. ${ }^{45}$

\subsection{1 "Compreender o lógos de seu ministério"}

Para além das pré-compreensões da crítica e da mais recente documentação arqueológica, todavia, é, em verdade, ainda o próprio testemunho de Platão a desencorajar um ceticismo exasperado em relação à existência de órficos e de um movimento a estes conexo. ${ }^{46}$ No Crátilo (400c), Platão refere-se aos oi amphi Orphéa, indicando com a expressão os autores das doutrinas órficas; na República, descreve-os como agyrtái e mánteis, sacerdotes itinerantes e adivinhos (Resp. II, 364b-c), com uma conotação bastante negativa, que os autores aproximam facilmente aos orpheoteléstai, os iniciados ao orfismo, que aparecem como impostores em autores como Teofrasto, Filodemo e Plutarco. ${ }^{47}$ Um bios orphikós é lembrando nas Leis (VI, 782c), no contexto da discussão sobre o vegetarianismo. Frequentemente, no interior da obra platônica, é recordada a antiguidade (e, portanto, anterioridade ao próprio Platão) de suas doutrinas; ${ }^{48}$ assim como são citados ou parafraseados textos órficos. ${ }^{49} \mathrm{E}$ impossível negar, portanto, que órficos e orfismo possuam lugar relevante e bastante significativo no interior do corpus platônico.

No entanto, a presença do orfismo na obra platônica é especialmente visível quando nela se faz referência a teorias sobre a alma. Os diálogos são de fato repletos de mitos, reflexões morais, imagens literárias que pressupõem ou enfrentam diretamente as temáticas relativas à imortalidade e à metempsicose da alma.

É esse certamente o caso de uma célebre página do Mênon, na qual Platão atribui a autoria da teoria da metempsicose a "grandes sacerdotes e sacerdotisas, que se preocupam em compreender o lógos de seu ministério"

${ }^{44}$ A posição cética de Brisson é, neste sentido, paradigmática (2000a: 253). Uma saída metodológica para o problema é certamente aquela proposta por Bernabé (2002: 239): "chaque foi que l'on parle d'influence orphique chez um auteur, on doit citer des textes soumis à une critique profonde et à une herméneutique minutieuse, pour éviter les lieux communs et les affirmations vides. Le travail reste em grande partie à faire et il est urgent de l'entreprendre". Mostrar os textos, portanto, eis o imperativo.

${ }^{45}$ Sobre o papiro Derveni, cf. o que foi dito acima 1.8 .

${ }^{46}$ Ainda que o termo 'O $\rho \varphi$ ıkó não seja registrado como tal no interior do corpus platônico, ele já aparece em Heródoto (II, 81, vide infra).

${ }^{47}$ Cf. para as citações Vegetti (1998: 229) e Burkert (1972: 125 n30 e 1982: 4 n13).

${ }^{48}$ Cf. Phlb. 66c; Leg. 715e.

${ }^{49}$ Cf. Phaed. 69c-d, Crat. 402b-c. Cf. para isso também Kingsley (1995:118) e Tortorelli Ghidini (2000: 12). 
(Men. 81a). O conteúdo desse logos é explicitamente afirmado em seguida: "ora a alma chega a um seu fim - este que é chamado morrer -, ora ela renasce, mas jamais é destruída por completo” (81b). Será o caso de examinar mais de perto a passagem em seu contexto. O tema do diálogo entre Sócrates e Mênon verte sobre a virtude, em chave mais propriamente de teoria do conhecimento. O problema em pauta é aquele de como reconhecer a verdade quando já não a se conheça antes: trata-se da questão, central para a filosofia platônica, da anamnese. Nesse contexto, Sócrates dialoga com Mênon nos seguintes termos:

SOCR. Pois ouvi dizer de homens e mulheres sábios das coisas divinas. MEN. O que eles diziam? SOCR. Coisas verdadeiras - parece-me - bonitas. MEN. Quais? E quem são estes que as falaram? SOCR. Sacerdotes e sacerdotisas, que se preocupavam em explicar o lógos do próprio ministério. $\mathrm{E}$ estas mesmas coisas [b] diz Píndaro e muitos outros poetas, os poetas divinos. $\hat{E}$ isso que ele dizem, mas veja se te parece que eles dizem a verdade: dizem, portanto, que a alma humana é imortal, e que ora ela tem seu fim, que se diz morrer, ora renasce, e que jamais é destruída; eis porque - dizem - precisa viver a vida o mais santamente possível.

Pois as almas daqueles de quem aceita expiação por uma antiga falta, Perséfone devolve, no nono ano, ao sol lá de cima. Delas brotam reis ilustres e homens poderosos e excelentes na sabedoria. E pelo resto de seus dias, como heróis imaculados, são invocados pelos homens.

A alma, portanto, por ser imortal e diversas vezes renascida, tendo visto o mundo deste e do outro lado, em uma palavra todas as coisas, não deixou de aprender nada. Não deve maravilhar que, portanto, pode chamar à mente novamente o que antes conhecia da virtude e do resto todo. Pois de fato a natureza é congênere (Men. 81a-c).

Sócrates, portanto, na passagem acima do Mênon, elabora uma espécie de súmula histórico-teorética das teorias da alma, articulando sua imortalidade com a ideia da metempsicose ("ora renasce, e jamais é destruída"). Atribui a autoria desta indiferentemente a dois sujeitos: antes a "sacerdotes e sacerdotisas que se preocupam em compreender o lógos do próprio ministério", e depois aos poetas divinos, entre eles Píndaro, do qual são também citados alguns versos. Não é difícil imaginar que, em relação aos referidos poetas, Sócrates devesse pensar também em Empédocles..$^{50} \mathrm{~A}$ função dialética da citação de Píndaro é fundamentalmente aquela de corroborar a ideia, expressa imediatamente antes por Sócrates, da palingênese (pálin gígnesthai) da alma, isto é, de seu nascer novamente (pálin gígnesthai).

${ }^{50} \mathrm{O}$ fr. 146 de Empédocles, de maneira especial, revela paralelismo muito significativo com os versos acima citados de Píndaro: "E, no fim, tornam-se adivinhos e poetas/ médicos e líderes para os homens que habitam a terra/ e deles brotam deuses, excelentes pela honras que recebem”. Vejam-se tanto as imagens biológicas para indicar a reencarnação (rebrotam em Píndaro, brotam em Empédocles), como as referências à excelência dos nobres reis de Píndaro, à qual pode ser

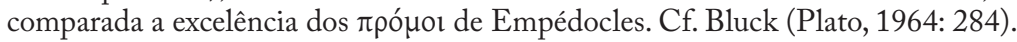


Deve-se notar que Platão - no lugar de citar algum poema órfico, que, como vimos, certamente deveria conhecer - recorre a versos de Píndaro. É este o primeiro sinal de algo que é, conforme se verá a seguir, uma marca da apropriação da teoria da imortalidade da alma pela obra platônica, isto é, de uma provável intenção de Platão de diluir a referência às origens órficas da teoria. Essa escolha platônica é ainda mais significativa se comparada com sua indicação da primeira referência à autoria da teoria, que é aos sacerdotes e sacerdotisas que se preocupam em compreender o lógos do próprio ministério. Wilamowitz (1920:II 249) e Burkert (1972:126) concordam que o objeto desta explicação do lógos (lógon didónai) de suas práticas rituais deva ser a mythología dos rituais ligados à metempsicose: tratar-se-ia, portanto, da exegese dos mitos que acompanham os rituais de iniciação da alma. A prática é aqui, geralmente, referida a personagens de âmbito pitagórico, contribuindo para recolocarmos Platão como fonte confiável da atribuição de teorias como a da imortalidade e da metempsicose aos pitagóricos antigos.

Prova disso seria a referência a sacerdotisas, em acordo com os diversos testemunhos que apontam para uma presença significativa e relativamente paritária das mulheres no interior da koinonía pitagórica; ${ }^{51}$ de fato, Kingsley (1995: 161-162) anota com razão que não há nenhuma tradição que permita considerar os rituais ou a mitologia órfica como inclusivos das mulheres: seria esta, portanto, uma indicação exclusiva do pitagorismo. ${ }^{52}$ Por outro lado, a ideia da explicação mito-lógica aponta provavelmente para aquela apropriação do orfismo que Pugliese Carratelli (2001: 18), baseando-se na análise das recém-descobertas lâminas órficas, identificava acima como pitagórica. ${ }^{53} \mathrm{Como}$ no caso da citação de Píndaro, portanto, Platão parece aqui querer referir-se mais diretamente àquela parte do complexo universo órfico mais próxima à sua sensibilidade filosófica e religiosa. E, em relação ao que interessa mais diretamente estas páginas, isto é, às teorias da imortalidade da alma e da metempsicose.

O testemunho mais contundente da historicidade dessa imagem de sacerdotes que, para além de cumprirem os ritos, demonstram interesse na sua explicação mitológica, é representado pelo próprio papiro Derveni. O papiro, que se apresenta como uma exegese alegórica de um antigo poema cosmogônico, em busca de uma explicação alegórica dos mistérios, na coluna $\mathrm{XX}$, empreende uma crítica sarcástica dirigida contra aqueles que não sabem fazer aquilo em que os sacerdotes e sacerdotisas acima citados no Mênon são ditos especialistas. Pois as personagens que são alvos da reprovação do autor do papiro se exibiriam em praça pública com rituais sagrados, mas não saberiam explicar os ritos que realizam:

${ }^{51}$ Cf. o que foi dito acima a este respeito (esp. 2.3), assim como De Vogel (1966: 238 n2); Dodds (1951: 175 n59), Burkert (1982: 17-18); Kingsley (1995: 162 n51).

52 Concorda com ele também Long (1948: 68-69). Casadio (1991: 130), porém, protesta que, se as mulheres eram admitidas nas comunidades pitagóricas, deviam sê-lo como filósofas, e não sacerdotisas. E Bernabé e Jiménez (2008: 59) apontam para o fato de diversas das mais recentes descobertas de lâminas órficas serem originárias de tumbas de mulheres. $\mathrm{O}$ consenso entre os comentadores é mais uma vez distante.

${ }^{53}$ Cf. acima (1.8). 
Em relação a estes quantos dos humanos que, nas cidades, realizaram ritos e viram as coisas sagradas, menos me espanto com eles não saberem (pois não é possível escutar e aprender as coisas ditas ao mesmo tempo). Mas quantos (se iniciam) junto a quem faz das coisas sagradas um artifício, estes (são) dignos de espanto e pena. Por um lado, espanto porque, achando, antes de realizarem o rito, que saberão, partem, tendo realizado os ritos, antes de saberem, nada perguntando, como se soubessem algo do que viram, escutaram e aprenderam. Por outro lado, pena porque não basta eles gastarem o dinheiro de antemão, mas também partem destituídos de razão. Antes de realizar os ritos das coisas sagradas, esperam saber, mas tendo-os realizado, partem destituídos também de esperança $\left(P\right.$. Derv. XX). ${ }^{54}$

Da mesma forma como Platão, portanto, o autor do papiro Derveni, ainda que no papel de exegeta órfico, parece tecer críticas a uma parte do mesmo universo órfico que recrimina por não saber explicar os ritos. A esta acusação de incompetência, somam-se outras, entre as quais a de promover tanto certa mercantilização do sagrado, considerando a menção a dinheiro cobrado aos fiéis, como a consequente descrença entre os fiéis.

Não surpreenderá, assim, que Platão use esta mesma imagem em uma célebre página de República (364b-c), no contexto da dura crítica a Museu e seu filho, Eumolpo, epônimo dos hierofantes de Eleusis. Platão não esconde críticas aos problemas que a difusão dos mistérios eleusinos estava criando para a cidade (Resp. II, 378a); chega até a fazer uma paródia destes para a iniciação do "homem democrático" (560d-e). ${ }^{55}$

[Eles] guiam os iniciados para o Hades com seu discurso, preparando para eles um simpósio de piedosos, no qual deitam-se com guirlandas, e daí adiante os fazem passar o tempo todo bebendo, pois acreditam que a melhor recompensa pela virtude seja uma eterna embriaguez (Resp. II, 363c-d).

Todavia, a passagem que nos interessa mais diretamente é aquela da página seguinte, na qual Platão descreve com tintas fortes um fenômeno social que devia ser bastante difundido naqueles anos, o de sacerdotes e adivinhos andarilhos:

Mas de todos esses discursos os mais surpreendentes são aqueles que fazem sobre os deuses e sobre a virtude, afirmando que os mesmos deuses destinaram para muitos homens bons infelicidade e uma vida ruim, e para quem é a eles contrário, uma contrária sorte. Sacerdotes mendigos e adivinhos, batendo às portas dos ricos, convencem-nos haver neles um poder que provém dos deuses, graças a sacrifícios e encantamentos, para emendar qualquer injustiça cometida pelo indivíduo ou por seus antepassados, por meio de prazeres e festas. Se alguém quer prejudicar um inimigo, a troco de uma módica quantia, o

${ }^{54}$ A tradução é de Gazzinelli (2007), a partir da proposta de organização do texto e da tradução de Laks e Most (1997).

${ }^{55}$ Cf. West (1983: 34ss.) e Vegetti (1998: 227 n5). 
convencem que poderá arruinar indiferentemente tanto o justo como o injusto, e com encantamentos e simpatias persuadir os deuses a se colocarem a seu serviço (Resp. II, 364b-c).

A página platônica revela significativamente quadro bastante parecido com aquele desenhado pela coluna XX do papiro Derveni: os andarilhos retiram da mesma forma a esperança dos fiéis, além de mercantilizarem seus serviços. Pelo fato de esses mesmos sacerdotes e adivinhos, imediatamente depois, exibirem aquela grande pletora de livros que passavam como obras de Orfeu e Museu (Resp. II, 364e), é lectio facilior identificá-los, ao menos parcialmente, com o orfismo. A crítica de Platão não deverá ser considerada, contudo, como uma crítica irrestrita ao orfismo, e sim - como no caso do papiro Derveni - como um posicionamento, quase que uma crítica interna, que implica a escolha de uma parte dele: certamente aquela mais afim à sua sensibilidade, que devia aproximá-lo, como já se acenou acima, mais imediatamente às teorias órficopitagóricas, no sentido dado ao termo pela lectio de Pugliese Carratelli (2001).

Por outro lado, a cobrança platônica não é algo inusual. Ao contrário, insere-se naquela que foi definida como uma "permeabilidade consciente" entre téchnai e Naturphilosophie (Gemelli, 2007b) e que é testemunhada pela polivalência - nesse sentido acima descrito - de personagens trágicas como o Prometeu da homônima obra pseudoesquileia (430 a.C?), que é, ao mesmo tempo, um adivinho e um prótos euretês em disciplinas como a astronomia, a medicina e a matemática. Ou mesmo Melanipe, na homônima tragédia de Eurípides ( $A$ sábia Melanipe), que proclama uma cosmogonia pré-socrática, afirmando tê-la apreendido de sua mãe, uma ninfa adivinha (fr. 495 Nauck).

As relações entre orfismo, pitagorismo e Platão, portanto, começam a se delinear de maneira mais clara, no sentido de uma apropriação do primeiro por este último, de certa forma mediada pelo segundo.

Nesse sentido, é certamente o caso de voltar para a página do Mênon $(81 \mathrm{a}-\mathrm{c})$ com a qual se iniciou esta análise do testemunho de Platão sobre as teorias da alma pitagóricas, para anotar dois outros detalhes realmente significativos para a interpretação aqui proposta. Primeiramente, a referência, no final dela, à syngéneia da natureza, que remete imediatamente para a ideia do parentesco universal do texto de Porfírio (VP: 19) com o qual começou este capítulo. Esta referência é mais um sinal de que Platão está entendendo remeter as teorias dos sacerdotes e poetas à vertente pitagórica do orfismo: não há de fato nenhuma referência na literatura ou nas lâminas órficas à ideia de parentesco universal. Em segundo lugar, é surpreendente a referência ao fato de que esses mesmos sacerdotes e poetas teriam pregado a necessidade de "viver a vida o mais santamente possível". A admoestação não é de fato necessária à leitura da passagem, pois a prova da tese epistemológica da anamnese, que, como vimos, representa o objeto central da passagem, é suficientemente demonstrada já pela pré-existência da alma ao longo de diversas encarnações. $\mathrm{E}$, todavia, Platão parece querer precisar que o movimento da metempsicose deve ser compreendido em sentido fundamentalmente moral. $O$ fato de mais 
uma vez não termos alguma referência clara a isso nas fontes órficas faz pensar que se trate, neste caso, mais uma vez, de uma variação pitagórica, certamente ao gosto platônico, da teoria da alma imortal.

\subsubsection{Hierarquia das encarnações}

A apropriação em sentido moral da metempsicose é também atestada em outra tradição sobre a imortalidade da alma, amplamente presente no corpus platônico: aquela da hierarquia das encarnações. Trata-se da célebre lei de Adrasteia, longamente discutida por Platão no Fedro, exatamente no contexto da demonstração da imortalidade da alma:

Eis agora a lei imposta por Adrasteia: cada alma que, havendo-se colocado ao séquito de um deus, contemple alguma das verdades eternas, estará livre de padecimentos até o próximo período, e no caso de sempre conseguir esta meta, será livre para sempre. Quanto ao contrário, incapaz de segui-lo, não alcança a contemplação, e por alguma desgraça, fica sobrecarregada por causa do esquecimento e da maldade que a invadem, enquanto, pesada como está, perde as asas e cai no chão, então a lei diz que esta alma não seja plantada em nenhuma natureza animal em sua primeira geração. Ao contrário, aquela que alcançou uma mais ampla contemplação, plantar-se-á na semente de um homem que será amante da sabedoria, ou amante do belo, ou das Musas ou do amor. Em segundo lugar, na semente de um rei legítimo ou um guerreiro ou um líder corajoso. Em terceiro, na de um político, de um administrador ou de homem de negócios; em quarto, na semente de um atleta, alguém que se dedica ao esforço, ou de alguém que se dedica à cura dos corpos; em quinto, a uma vida de adivinho ou de alguém que sabe iniciar-se aos mistérios; ao sexto lugar será conveniente a vida de um poeta ou de outro homem apto à imitação; na sétima... (Phaedr. 248c-e).

A imagética da plantação da alma em diversas sementes retoma diretamente os textos acima citados de Píndaro e Empédocles, assim como a ideia da hierarquia das reencarnações, já presente dos textos de ambos. Ainda que Platão coloque - como é de se esperar - no topo da hierarquia exatamente os filósofos, as posições imediatamente sucessivas lembram de perto aquelas dos dois antecedentes: reis, atletas e poetas em Píndaro, enquanto Empédocles prefere a eles adivinhos, poetas e médicos além, obviamente, dos próprios reis. Platão, polemicamente, empurra para baixo, no ranking das reencarnações, os políticos, os médicos e os atletas.

O fato, todavia, de não haver alguma fonte órfica direta que apresente esta hierarquia faz pensar na sua invenção em âmbito aristocrático e da Magna Grécia, imediatamente recebida por Platão novamente no interior de seu projeto moralizador da metempsicose acima citado. ${ }^{56}$ Isso explicaria também o porquê, na citação acima do Mênon (81a-c), de Platão preferir citar Píndaro no lugar dos órficos: a intenção, à qual se acenava acima, de diluir

\footnotetext{
${ }^{56}$ Cf. para esta hipótese Bernabé (2011, cap. 6).
} 
a referência às origens órficas da teoria pode responder diretamente a este projeto de moralização da metempsicose, para o qual a tradição da hierarquia das reencarnações devia servir muito bem. $\mathrm{O}$ âmbito aponta, novamente, para as tradições pitagóricas itálicas.

A economia destas páginas sugere evitar entrar diretamente em duas questões centrais da passagem acima citada do Fedro, isto é, no problema da duração do ciclo das sucessivas reencarnações e naquele da referência a Adrasteia como autora da lei. Baste aqui anotar que, por um lado, não há coerência doutrinária em relação ao número de anos que corresponderia ao completamento do ciclo. ${ }^{57}$ Por outro lado, Adrasteia (etim. "aquela da qual não se pode fugir"), antes de se tornar a temida vingadora de toda tentativa humana de desafiar o divino (Aesch. Prom. 936; Resp. V, 451a), aparece nas cosmologias órficas como companheira de Dike (fr. 23 Kern), associada a Nêmesis e ela mesma entidade cosmogônica (fr. 54 Kern). ${ }^{58}$ Corresponde fundamentalmente à mesma personificação da Anánke que rege o mundo no livro X de República, e cujo decreto é dito, em Empédocles, regular o ciclo da metempsicose (115 B1 DK). Em ambos os casos, de toda forma, Platão parece mais uma vez reelaborar criativamente os dados da tradição órfica, para que esta venha obedecer a seus próprios interesses teórico-redacionais.

\subsubsection{Sôma-sêma}

A mesma transposição Platão realiza em relação a outro grande motivo das teorias da imortalidade da alma, aquele que corresponde ao célebre mote sôma-sêma ${ }^{59}$ Novamente, a análise desta questão buscará, de um lado, perceber a maneira tipicamente platônica de apropriar-se de uma teoria órfica no interior de sua própria concepção da imortalidade da alma; por outro lado, apreender, no revés do tecido da fonte platônica, sinais das dependências entre orfismo e pitagorismo em relação a suas respectivas teorias da imortalidade da alma.

Em uma página do Górgias, Sócrates, em resposta à proposição de Cálicles sobre a necessidade de uma liberação total das paixões em busca do prazer, introduz, com o verso de Eurípides - "Quem sabe se viver é morrer e morrer é estar vivo?" - uma discussão sobre o corpo (sôma) como tumba (sêma) da alma, cuja autoria Sócrates refere a "um homem de refinada inteligência, siciliano ou itálico”. Assim reza o texto:

Mas mesmo a vida da qual você está falando é terrível, e nem ficaria maravilhado que Eurípides dissesse a verdade, quando se pergunta: Quem sabe se viver é morrer e morrer é estar vivo? $\mathrm{E}$ de verdade pode ser que nós, na realidade, estejamos mortos! Conforme ouvi dizer até dos sábios: que atualmente somos mortos e que nossa tumba é o corpo, e aquela parte da alma na qual tem sua sede as paixões, por sua natureza se deixa arrastar, e para cima e para baixo se deixa empurrar. Isso disse, sob a forma de mito, um homem de refinada

\footnotetext{
${ }^{57}$ Cf. para isso Bernabé (2011, cap. 6).

${ }^{58}$ Cf. para as citações Casadio (1991: 132).

${ }^{59}$ Utiliza-se aqui o termo transposição no sentido cunhado a partir de Diès (1927: 432ss.).
} 
inteligência talvez siciliano ou itálico; com um jogo de palavras chamou vaso aquela parte da alma que tão fácil de ser persuadida, e não iniciados chamou os homens "sem-juízo". Nestes, a parte da alma em que residem as paixões, sua devassidão e permeabilidade, desenhou como um vaso furado, querendo dessa forma significar sua insaciabilidade. No sentido contrário, invés àquele que você defende, Cálicles, ele mostra que entre todos os que estão no Hades - e com Hades entende o invisível - exatamente estes são os mais felizes, enquanto os não iniciados são condenados a entornar a água em um vaso furado com uma concha, também furada. A concha - dizia quem me relatou esta história significava a alma dos sem-cabeça, pois furada e incapaz de conter em si mesma qualquer coisa, por sua incredulidade e esquecimento ( Gorg. 492e-493c).

É o caso de notar, inicialmente, que Platão, como era de se esperar pelo padrão de suas estratégias de transposição até aqui notado, utiliza o motivo sôma-sêma em um contexto dialógico marcadamente ético-apocalíptico. ${ }^{60}$ Ao mesmo tempo, refere a origem deste, "sob a forma de mito, a um homem de refinada inteligência, talvez siciliano ou itálico". A referência de Platão faz pensar em uma origem órfica e/ou pitagórica do motivo. De fato, o kómpsos anér ao qual Sócrates se refere é comumente identificado com algum pitagórico. Há quem quis identificá-lo com o próprio Filolau, por causa da referência ao mesmo tema que aparece no fragmento 14 deste último:

Atestam os antigos conhecedores das coisas divinas e os adivinhos que, por causa de certas punições, a alma encontra-se conjunta ao ápice das carnes do corpo e está como sepultada neste túmulo (44 B 14 D-K).

Filolau, de sua parte, parece referir a doutrina do sôma-sêma, de maneira muito precisa, às tradições mágico-religiosas arcaicas: theologoi e mantiess. ${ }^{61}$

O problema é que, desde Wilamowitz (1920: II 90) e Frank (1923: 301), até Burkert (1972: 248 n.47), Casadio (1991: 124 n9) e mesmo Huffman (1993: 404-406), muitos comentadores duvidam seriamente da originalidade deste fragmento, e, por consequência, da possibilidade de considerar a ideia do sôma-sêma como originalmente filolaica. ${ }^{62}$ Os argumentos são basicamente os seguintes: a) há evidências de contaminação do texto, com as doutrinas de Platão (Crátilo 400c) e Aristóteles (fr. 6 Rose); b) reminiscências linguísticas aproximariam seu vocabulário àquele posterior, marcadamente de época platônica; c) seria estranho que um pitagórico como Filolau atribuísse a teoria do sôma-sêma, considerada comumente pitagórica, a antigos theologoi e adivinhos; d) o termo usado por Filolau, psyché, assume, neste fragmento,

${ }^{60}$ A referência do diálogo a doutrinas pitagóricas não se resume a este contexto. Veja-se,

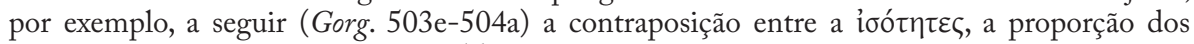
elementos da vida ética, e a $\pi \lambda \varepsilon o v \varepsilon \zeta i ́ \alpha$ de Cálicles, que ecoa diretamente a mesma discussão presente no fragmento 3 de Arquitas. Para um comentário a esta correspondência cf. Meattini (1983).

${ }^{61}$ Cf. Casadio 1987: 230.

${ }^{62}$ Sobre as questões historiográficas mais gerais relativas à originalidade dos fragmentos de Filolau, cf. acima (1.7). Cf. também Guthrie (1962: 329s). 
conotação muito próxima àquela posteriormente definida como complexo das faculdades psicológicas; isso estaria em contradição tanto com a concepção de alma como vida, acima analisada em relação a seu fr. 13 (no interior do comentário ao fr. 7 de Xenófanes), como àquela expressa pelo fr. 22, pelo qual "a alma ama o corpo" ${ }^{63}$ Enquanto os primeiros três argumentos em favor da consideração do fragmento como espúrio podem ser facilmente refutados, o quarto merecerá reflexão mais cuidadosa.

Em relação aos primeiros dois argumentos (contaminação doutrinária e reminiscência linguística), é fácil argumentar ao contrário que: a) as doutrinas expressas por Filolau não parecem de nenhuma forma anacrônicas, e o fato de serem citadas por Platão e Aristóteles pode sugerir que os três simplesmente a retiraram de uma fonte comum, provavelmente de tradição órfica, bastante difundida nos séculos $\mathrm{V}$ e IV aEC; b) ainda que o termo theologia apareça pela primeira vez somente em Platão (Resp. II, 379a), segundo Vlastos (1952: 12 n22) o termo é de uso geral. Significativamente, é Adimanto quem o traz à tona no diálogo, e não Sócrates, indicando com isso tratar-se mais provavelmente de um termo já em uso do que de uma criação platônica. ${ }^{64}$ Por outro lado, os argumentos de Wilamowitz e Frank sobre o vocabulário são subjetivos e dificilmente compartilháveis: o estilo do texto somente pareceria um falso dórico, enquanto esconderia de fato, por trás dele, inconfundível clareza ática. Trata-se de uma afirmação que não permite verificação. Em relação ao terceiro argumento, o da incongruência de um pitagórico relacionar uma teoria também pitagórica como a do sôma-sêma a antigos teólogos e adivinhos, podem-se apresentar ao menos dois contra-argumentos: primeiramente, não está demonstrada a origem pitagórica da doutrina, que, ao contrário, poderia ser de início uma tradição órfica; em segundo lugar, ainda que se admita a possibilidade de ser pitagórica, as modalidades da pertença do pitagórico Filolau ao movimento pitagórico, isto é, a imagem que este homem do século $\mathrm{V}$ aEC devia fazer da tradição da filosofia pitagórica em suas origens, não está de forma alguma esclarecida. Nada, de fato, impede de pensar - fora o costumeiro preconceito presentista - que Filolau considerasse as origens do movimento intelectual ao qual pertencia muito bem representadas por theologoi e manties, da sophia dos quais se considerava devedor.

Por outro lado, o quarto argumento merece uma consideração mais atenta, como se dizia, fundamentalmente por trazer à tona aquela que possui aparentemente todas as condições de ser considerada como uma contradição no pensamento de Filolau, em relação à sua concepção da alma. Os fr. 13 e 22 apresentam, nesse sentido, dois problemas distintos e complementares para a ideia de psyché que subjaz ao fr. 14 e fazem um atento leitor de Filolau como Huffman pender para considerar este último como duvidoso (1993: 405-406).

${ }^{63}$ Cf. para a resenha destes argumentos, tanto Burkert (1991: 404-406) como Bernabé (2011, cap.7).

${ }^{64}$ A prova disso, Burkert (1993: 405) anota com razão que a frase $\alpha \dot{\mu} \varphi \grave{i} \theta \varepsilon \tilde{\omega} v \lambda \lambda^{\prime} \gamma o \varsigma$ aparece, por exemplo, já no fr. 131 de Empédocles (31 B131 DK). 
No caso do fr. 13, acima analisado, concluímos que o termo psyché, que lá aparece com o sentido de harmonia e composição de elementos materiais, é evidentemente contraditório com aquele de sua imortalidade e que, portanto, Filolau - que, como pitagórico, deveria possuir alguma teoria ou crença na imortalidade da alma - deveria utilizar outro termo, que não psyché, para referir-se à parte do indivíduo que alcança a imortalidade. No caso do fr. 22, a expressão "a alma ama o corpo" (diligitur corpus ab anima), que aparece no fragmento citado por Claudiano Mamerto (44 B22 DK), sugere novamente evidente contradição com a ideia do corpo como tumba. ${ }^{65}$

E todavia, a querer procurar uma solução para os dois impasses, poderse-ia, em relação ao primeiro, conjecturar que, se de fato a presença do termo psyché obrigaria a considerar o fragmento quanto menos duvidoso, o restante do fragmento não cria mais dúvidas sobre sua autenticidade. Este fato permitiria imaginar que o termo psyché, e somente ele, seja fruto de uma correção de Clemente ao termo original filolaico (que podia ser daimon, por exemplo), ao qual substituiria o novo termo, mais congruente com seu vocabulário, e tradicionalmente (mas somente mais tarde) utilizado para indicar a parte imortal do indivíduo.

Em relação à contradição entre a ideia de um corpo-tumba e o amor da alma por ele do fr. 22, uma solução muito elegante e eficaz foi proposta já por Timpanaro Cardini:

Deve-se considerar que na misteriologia órfico-pitagórica o corpo é lugar e meio de expiação, para alcançar a libertação da alma; daí uma certa ligação afetiva da alma em relação à sua própria custódia (1962 II, 246-7).

Assim, o amor da alma pelo corpo é, coerentemente, o amor pela possibilidade de expiação das culpas das vidas anteriores. Expiação, esta, que só era possível através do corpo, portanto a solução tem o mérito de aproximar o fragmento do âmbito conceitual das teorias da metempsicose. Nesse mesmo sentido, na frase imediatamente seguinte, o fr. 22 acrescenta: "pois sem este não pode utilizar os sentidos" (quia sine eo non potest uti sensibus). O sujeito da frase é ainda a alma, que sem o corpo não pode utilizar os sentidos, receber e emitir sinais. Trata-se do mesmo campo semântico da teoria do sôma-sêma como interpretada, como ver-se-á logo a seguir, por Platão no Crátilo (400c), isto é, do corpo como sinal. O corpo apresenta-se, assim, no fr. 22 de Filolau, como uma custódia relativamente aberta, que permite a interação com o mundo, isto é, alguma forma de conhecimento e expressão. Ver-se-á em breve esta mesma ideia expressa na página platônica agora citada.

Em resumo, Filolau parece remeter, em seu fr. 14, à teoria da imortalidade da alma para uma origem certamente anterior a ele mesmo, com certa probabilidade de ser - até mesmo - externa ao próprio pitagorismo, ou, pelo

${ }^{65}$ Incisivo, nesse sentido, Casadio (1991: 124 n9): "per quanto ci si arrampichi sugli specchi non si riuscirà mai a far dire a Filolao che è un sepolcro l'involucro corporeo di cui l'anima si compiace". 
menos, certamente anterior ao pitagorismo do século $\mathrm{V}$ aEC do qual Filolau é o maior representante. $\mathrm{E}$, neste ponto, parece concordar com a página do Górgias de Platão acima citada, isto é, da origem em âmbito religioso e antigo dessas mesmas teorias. Ainda que não seja ele mesmo o kómpsos anér citado por Platão, portanto, Filolau constitui um testemunho central, ao mesmo tempo, da antiguidade das doutrinas e de sua acolhida muito cedo no interior da literatura pitagórica.

Achados recentes (datados em 1951) parecem confirmar a existência em âmbito órfico da teoria do sôma-sêma: trata-se mais especificamente das três placas de osso descobertas em Ólbia. ${ }^{66} \mathrm{Na}$ primeira (94a Dubois) e na terceira (94c Dubois), leem-se algumas sequências de nomes, que se iniciam ou terminam com o teônimo DION, uma abreviação de Dioniso:

Vida Morte Vida
Verdade
Dion(iso) Órficos
Dion(iso)
[Mentira] Verdade
Corpo Alma

$\mathrm{Na}$ primeira placa, a sequência vida-morte-vida é dita verdade e referida exatamente aos órficos. A placa contém pela primeira vez o nome Orphikoí. Antes da descoberta, o primeiro aparecimento do termo era atestado somente em Heródoto (II, 81), em uma página que será analisada a seguir. ${ }^{67}$ Há, nesta, uma inversão apocalíptica, tipicamente órfica, da valoração da morte como verdadeira vida (da alma, obviamente). Impossível não pensar, nesse mesmo sentido, na citação platônica acima dos versos de Eurípides: "Quem sabe se viver é morrer e morrer é estar vivo?" (Gorg. 492e), assim como em toda a argumentação de Sócrates na página do diálogo ${ }^{68} \mathrm{O}$ fato é que a expressão sôma-sêma acaba por tornar-se como um mote, ou melhor - utilizando um termo pitagórico - um sýmbolon da teoria órfica da imortalidade da alma.

Aceitando-se a reconstrução da terceira placa por Vinogradov (1991: 77-86) haveria nela, na terceira linha, exatamente a antonímia sôma-psyché que encontramos no texto platônico e em Filolau. Lidas em conjunto, as duas placas revelam indiscutivelmente - e em âmbito declaradamente órfico - crença na imortalidade da alma, enquanto algo que sobrevive ao corpo mortal. ${ }^{69}$

${ }^{66}$ Se ocuparam das placas de osso de Olbia especialmente West (1982); Zhmud (1992); Dubois (1996); Tortorelli Ghidini (2006).

${ }^{67}$ Cf. para mais ampla discussão da grafia exata e do sentido do termo, Graf (2000). O sufixo -lko indicaria um grupo marcado pela diferenciação, uma seita dionisíaca "herege" (Burkert 1982: 12).

${ }^{68}$ Cf. para uma análise exaustiva desta ideia na literatura órfica Bernabé (2007b).

${ }^{69}$ Cf. para isso também West (1982: 18-19) e Casadio (1991: 125). De ideia contrária Burkert (1980: 37 e 1972: 133). 
Na página do Górgias (492e-493c) com a qual começamos esta seção, a grandeinteligência do "homem siciliano ou itálico"é de certa forma exemplificada por uma série de jogos etimológicos que marcam significativamente a segunda parte da citação. Com um jogo de palavras (lit. uma mudança de termos, parágon tô onómati), o sábio chamou pithos (vaso) aquela parte da alma que é pithanos (facilmente persuadível), e amuétoi (não iniciados) os homens anoétoi (que não têm "juízo"). O jogo estende-se até o ponto de abranger a própria etimologia do Ádes (Hades), o reino do além-túmulo, que é entendido como áides (invisível).

Não maravilha, portanto, que o mesmo motivo sôma-sêma mereça um jogo etimológico refinadíssimo em célebre página do Crátilo (400c) já amplamente estudada pela crítica. ${ }^{70}$ Ao que parece, a própria ideia do mote sôma-sêma evoca esta tipologia antiga de reflexão sobre nomes e realidade. Ao mesmo tempo, o kompsós anér do Górgias e os antigos teólogos e adivinhos de Filolau encontram nesta página do Crátilo, pela primeira vez, uma atribuição mais precisa: tratase aqui de "discípulos de Orfeu":

De fato alguns dizem que [o corpo] seja tumba da alma, como sepultada nisso na vida presente; e pelo fato da alma por sua vez significar, por causa disso chama-se corretamente sinal. Todavia, parecem-me que foram em primeiro lugar os discípulos de Orfeu aqueles que deram este nome, como se a alma, enquanto está pagando a pena por aquilo pelo qual está pagando, possui, para que se salve, este revestimento feito à imagem de uma prisão: da alma este é assim denominado salvação até que não pague suas dívidas, e não é preciso mudar uma só letra (Crat.400c).

É preciso obviamente desvendar o articuladíssimo jogo de palavras que constrói o texto e que envolve não somente dois diferentes sentidos para o termo sêma (tumba e sinal), mas também a reinvenção - toda platônica - de um novo sentido para o termo sôma, que de corpo acaba por significar salvação.

Sócrates revela aqui, portanto, conhecer dois sentidos diversos do termo sêma: de um lado, tumba; do outro, sinal. A assonância tem evidentemente papel central na compreensão da página: Sócrates devia conhecer bem o mote órfico sôma-sêma, no sentido de corpo-tumba, mas conhece também uma exegese diferente do mote, que - de certa forma - diminui o impacto cruento e arcaico da imagem, provavelmente ligado originalmente aos ritos das teléstai, como as placas de Ólbia acima citadas parecem indicar, refinando-a para inseri-la em um âmbito semântico mais intelectualista. O jogo é possível, provavelmente, graças ao sentido arcaico do termo sêma, já homérico, que significaria não tanto a sepultura, e sim, mais precisamente, a lápide funerária que é erigida para indicar, sinalizar o lugar da sepultura e, por consequência, para lembrar da

${ }^{70}$ Cf. Rohde (1898: 130, n2); Tannery (1901: 314s); Wilamowitz (1932: I 199); Rathmann (1933: 65 e 82); Nilsson (1935: 205s); Dodds (1951: 148s); Guthrie (1952: 156s); Timpanaro Cardini (1962: II 228s); Burkert (1972: 126 n33 e 248 n47); Alderink (1981: 62); De Vogel (1981: 79s); Bestor (1980: 306s); Ferwerda (1985); Casadio (1987: 389s e 1991: 123s); Riedweg (1995: 46); Zhmud (1997: 123). Maravilha-se ao contrário Bernabé (2011, cap. 7). 
pessoa ali sepultada. ${ }^{71}$ Por outro lado, a exploração dessa translação semântica corresponde, provavelmente, ao mesmo âmbito exegético ao qual se refere o papiro Derveni, isto é, aquele de um trabalho de exegese alegórica dos mitos órficos antigos (cf. acima 1.8).

Diversos autores, desde Wilamowitz (1932: II 199), sugerem tratar-se aqui de uma exegese pitagórica do mote órfico. ${ }^{72}$ Todavia, esta atribuição não é consensual. De fato, ainda que Burkert afirme inicialmente: "podemos supor que, se não for órfico, seja possivelmente pitagórico”, por outro lado acaba por concluir, ceticamente, que "não sabemos nem sequer se existiu historicamente algo deste tipo" (1972: 248 n47). ${ }^{73}$ É certo que, se o fragmento de Filolau acima citado (44B14 DK) não autoriza atribuir a interpretação de sêma como sinal, e sim, mais precisamente, como tumba, por outro lado, a hipótese levantada por Pugliese Carratelli (2001) de um trabalho mito-lógico do pitagorismo sobre as tradições órficas poderia sugerir com certa probabilidade que esta etimologia fosse próxima aos ambientes pitagóricos, senão mesmo de autoria destes últimos. ${ }^{74} \mathrm{Um}$ argumento indireto que autorizaria a atribuição ao pitagorismo da ideia do corpo como sinal é o fato da prática didática simbólica que, conforme vimos acima (2.2) deveria marcar o estilo de vida pitagórica: sýmbola e acusmata indicando que uma coisa significa o tempo todo outra. ${ }^{75}$ Consequência esta, do ponto de vista teórico, da continuidade da realidade, de sua syngéneia, na qual tudo remete para tudo. ${ }^{76}$

No entanto, o que mais surpreende pela fineza do trabalho de textura etimológica é a terceira passagem do texto. O sucesso do jogo etimológico é sublinhado pelo mesmo Sócrates, que, ao final do argumento, declara

${ }^{71}$ Para as citações de Homero, cf. Il. II 814 e VII 319; Od. II 222, e XII 175. Para o sentido de $\sigma \tilde{\eta} \mu \alpha$, cf. Liddell-Scott (1996). Para a discussão do termo, cf. Prier (1978: 91-101).

${ }^{72}$ Cf. entre eles Thomas (1938: 51-52) e Dodds (1951: 171 n.95).

${ }^{73}$ Orig.: "we may suppose that if it is not Orphic, it is likely to be Pythagorean" e "we do not know whether this was a historical character".

${ }^{74}$ Esta é certamente boa maneira de resolver, na página platônica, a oposição entre aqueles

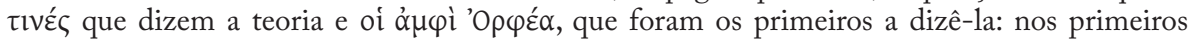

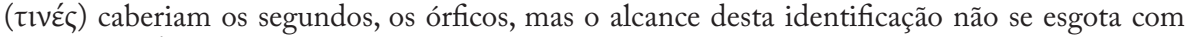

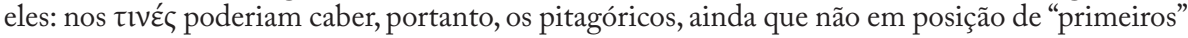
a sustentar esta teoria.

75 Significativa, nesse sentido, a página de Estobeu (Stob. Flor. 3.1.199): “de fato, não há nada de tão próprio da filosofia pitagórica como o simbólico, como uma forma de ensino na qual palavra e silêncio se misturam, como para não dizer". Por outro lado, a ideia da sinalização simbólica não seria algo restrito à tradição pitagórica, mas é amplamente presente no restante da literatura pré-socrática. Veja-se, como exemplo, o fr. 93 de Heráclito: "o senhor de que é o oráculo de Delfos, não fala nem esconde, sinaliza" (22 B 93 DK).

${ }^{76}$ Não procede a argumentação de Ferwerda (1985: 270-272) que tende a mostrar que - ao contrário - o primeiro sentido etimológico do corpo como tumba da alma não pode ser pitagórico. $\mathrm{O}$ autor argumenta que, por um lado, uma ideia tão pessimista não combinaria com a

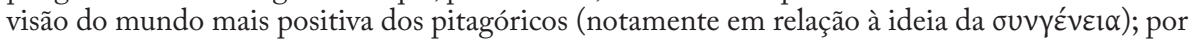
outro lado, argumenta que não faria sentido imaginar que um pitagórico pensasse na morte da alma durante a vida terrena no corpo. O equívoco do autor reside em considerar, nos dois casos, a morte da alma no corpo como algo definitivo, em vez de pensá-la como continuamente renascida, pensando assim na morte como ao começo de uma nova vida, no percurso da metempsicose. 
orgulhosamente “e não é preciso mudar uma só letra!". Trata-se aqui da aproximação de sôma com o verbo soízo, que acaba por deslizar semanticamente o termo sôma para o âmbito da salvação. Linguisticamente, o jogo é claro: Sócrates considera so-ma como um nome composto por so- (de soizo, salvar) e - ma, sufixo que indica ação. Sô-ma torna-se, assim, um nome de ação, uma hábil construção morfológica de Sócrates-Platão que quer significar que o corpo é salvação da alma. Por esse motivo, Sócrates pode afirmar não ser preciso mudar uma só letra, como, ao contrário, é pressuposto no caso do jogo sômasêma, no qual há uma troca entre ômicron e eta. Dessa forma, e somente em consequência dessa nova etimologia soteriológica, fará sentido para Sócrates a imagem do corpo como períbolos, revestimento da alma, feito à imagem de um desmotérion, de uma prisão. Entre os poucos comentadores desta passagem, De Vogel (1981) e Ferwerda (1985) concordam que, com essa proposta etimológica, Platão estaria de fato recusando a visão totalmente pessimista do corpo como tumba, em favor de uma imagem menos definitiva, como aquela do períbolos ou mesmo do cárcere. ${ }^{77}$ Aqui está o ponto teorético central: dizer que o corpo é revestimento e prisão da alma é algo bem mais leve do que dizer que é sua tumba. ${ }^{78}$ Como bem observou Timpanaro Cardini (1962), a etimologia "denota tendências culturais mais próximas à idade de Sócrates" e deverá corresponder, portanto, à sua própria lectio da tradição do motivo sômasêma, como sugere a própria expressão dokoûsi moi. ${ }^{79}$

Corresponderá, mais precisamente, à transposição platônica da tradição sôma-sêma no interior de seu próprio universo conceitual, bem exemplificada

${ }^{77}$ É significativa aqui a posição expressa por De Vogel: "all this, I think, brings out fairly clearly that those modern authors who write and speak as if the $\sigma \tilde{\omega} \mu \alpha-\sigma \tilde{\eta} \mu \alpha$ formula were the most adequate expression if Plato's view of man and human life, can do so only by a certain misinterpretation of the function of that formula in Plato's thought. For in fact, Plato took human life much more as a challenge than as some kind of penance" (1981: 98). Por outro lado, não parece fazer muito sentido demonstrar - como quer fazer Ferwerda (1985: 274) - que o termo

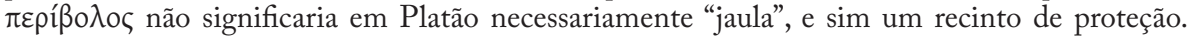
Ainda que a resenha proposta do termo ao longo do restante da obra platônica seja convincente,

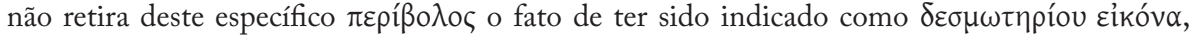
devendo ser de "jaula", no contexto da passagem, seu significado mais preciso.

${ }_{78}$ Ainda que Casadio as considere "metafore che esprimono con gradazione diversa lo stesso concetto" (1991: 124), todavia é possível pensar em mudança de rumo mais precisa na passagem platônica, como veremos a seguir. Concorda com ele Guthrie (1952: 311).

79 Timpanaro Cardini 1962 II, 229. Orig.: "risente di tendenze culturali più vicine all'età di Socrate". Cf. também Nilsson: "It may, however, seem doubtful whether the etymologies

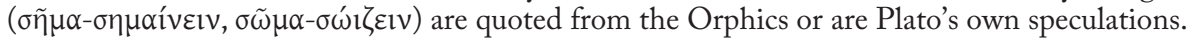
It may be doubted if such etymological speculations are appropriate for the Orphics, and it seems not unlikely that Plato added them as explanatory comments intended to illuminate the saying" (1935: 205). E Casadio "ciò che Platone attribuisce agli Orfici è l'idea dell'espiazione delle colpe, non necessariamente il legame etimologico tra sòma e sòzo" (1987: 390). Apesar disso, é certamente o caso de notar, com Bernabé (2011, cap. 7) que nas duas lâminas órficas de Pelinna, datadas do século IV a.C, encontramos a mesma ideia de libertação da alma do corpo: "acaba de morrer, acaba de nascer, ou três vezes bem-aventurado, neste dias. Diga a Perséfone que o próprio Baco te libertou” (Cf. Tortorelli Ghidini 2006: 84-85). Para argumentos a favor de uma atribuição já órfica da ideia do corpo como salvação, cf. Ferwerda (1985: 267). 
por uma página do Fédon em que o tema do cárcere da alma assume fortes conotações éticas:

Aqueles que amam o conhecimento bem sabem que a filosofia toma sua alma, que é realmente acorrentada, em uma palavra, colada ao corpo; condenada a perscrutar as coisas que são como através de uma prisão, e jamais por si mesma, e está envolvida em total ignorância. E ainda que intua que este cárcere é terrível por causa da paixão, enquanto quem se encontra nele acorrentado acaba por ser ele próprio o artífice de seu acorrentamento... (Phaed. 82e).

A prisão da alma no corpo, portanto, é constituída de ignorância e paixão. No entanto, ainda é passível da intervenção pedagógica da filosofia, que tenta "descolar" a alma do corpo, ampliando sua visão. O que importa sublinhar aqui, em perspectiva platônica, é que a imagem corpo-prisão permite esta intervenção da filosofia, enquanto a simples equação corpo-tumba não. $\mathrm{E}$, com isso, a moralização platônica das teorias da imortalidade da alma atinge seu ponto mais alto e, ao mesmo tempo, provavelmente mais distante de sua origem órfica.

Sinal inequívoco da nova síntese platônica das diversas etimologias é uma página do Fedro (250c) em que aparecem, novamente articuladas - e sem o mínimo sinal de tensão entre elas - as duas imagens do corpo como prisão e como tumba: as almas encontram-se no nível mais alto de sua iniciação, junto a Zeus, e são descritas como "estando puras e sem marcas deste que agora carregamos conosco e chamamos corpo, ao qual estamos presas à maneira das ostras" (Phaedr. 250c). A remissão ao jogo etimológico do Crátilo acima citado é evidente no uso do termo asématos, que traduzimos "sem marcas", mas que, enquanto composto de alfa+sema, pode carregar, e certamente carrega, o sentido de "não sepultado". Assim a página poderá ser lida como: "estando puras e não sepultadas neste que agora carregamos conosco, ao qual estamos presas à maneira das ostras". Novamente o tema sôma-sêma, portanto, a jogar entre os sentidos de tumba e sinal. ${ }^{80}$

\subsubsection{Mediação pitagórica}

O caminho aqui traçado, balizado pelos textos-chave da obra platônica, permite alcançar algumas conclusões, ainda que provisórias, sobre qual seja o sentido da presença das teorias da metempsicose órficas e pitagóricas no interior do corpus.

Primeiramente, é possível afirmar que há, na obra platônica, remissão bastante clara a uma origem, ao mesmo tempo antiga, religiosa e itálica, de teorias da imortalidade da alma que encontramos paralelamente na literatura órfica e na primeira literatura pitagórica, notadamente em Filolau. Foi certamente esse o caso do mote sôma-sêma, há pouco analisado.

${ }^{80}$ Cf. para isso Ferwerda (1985: 269), Casadio (1987: 389 n1) e Bernabé (2011, cap.7) que apresenta interessante quadro sinóptico desta passagem com a paralela do Crátilo (400c), no sentido de mostrar a derivação da primeira da segunda. 
Em segundo lugar, a apropriação platônica de teorias da imortalidade órficas supostamente originárias é marcada por uma intenção moralizante, como bem demonstraram a insistência na hierarquia das reencarnações e mesmo a original etimologia soteriológica platônica para o motivo do sôma-sêma. Não é impossível, por outro lado, concluir que essa transposição tenha sido mediada por um movimento, como aquele pitagórico, que, ainda que provavelmente próximo, tanto geograficamente como socialmente, à mitologia e à ritualidade das teléstai órficas, de certa forma contribui para "apolinizar o orfismo" na célebre expressão de Ciaceri (1931-32), ou seja - conforme a lectio em seguida partilhada também por Burkert (1972: 132-133) e Pugliese Carratelli (2001: 17-29) - a intelectualizar e aristocraticizar as tradições órficas. Estas, originalmente desenvolvidas por indivíduos andarilhos e à margem da cultura e religião políade, foram aos poucos (e sempre parcialmente) incorporadas no novo contexto sociocultural das colônias dóricas da Magna Grécia do século IV e depois $\mathrm{V}$ a.C. ${ }^{81}$

Não é possível avançar mais neste sentido da definição de uma precisa distinção, em relação às teorias da alma, entre a tradição órfica e aquela pitagórica. Alguns autores sugerem que o ponto de distinção possa ser aquele da culpa originária. Inicialmente, a metempsicose não deveria ter sido considerada, entre os pitagóricos, como um castigo, e sim como consequência lógica da imortalidade da alma. Em um segundo momento, a influência representada pelo mito antropogônico dos Titãs e de Dioniso, com a consequente antropologia da dupla natureza do homem e da necessária expiação do crime originário, levaria o pitagorismo a adotar a mesma concepção órfica, por esta servir muito bem a suas intenções moralizantes. ${ }^{82}$ No entanto, não há bases textuais sólidas para essas afirmações; o que sugere que seja mesmo o caso de parar por aqui.

$\mathrm{O}$ texto platônico frequenta, portanto, em diversos e muitos lugares as teorias da imortalidade da alma e da metempsicose, contribuindo - de certa forma - para acostumar nossos ouvidos a esse imaginário órfico-pitagórico da metempsicose. Isso, todavia, pode levar à impressão, enganosa, de que essa ideia deveria ser comum na cultura grega em que Platão se encontra. Ao contrário, Platão assume aqui uma ideia bastante estranha e exótica, recebida do orfismo, provavelmente pelo pitagorismo. Os próprios textos platônicos, em seu tecido dialógico, deixam transparecer a estranheza das teorias da imortalidade da alma para a cultura de seu tempo. É este o caso da resistência de Cebes, no Fédon (69e-70a) a aceitar que a alma tenha, longe do corpo, existência própria; como também de Glauco na República $(\mathrm{X}, 608 \mathrm{~d})$, que declara jamais ter ouvido falar da imortalidade da alma.

A estranheza das práticas e das doutrinas pitagóricas da imortalidade da alma coincide e articula-se com outra estranheza, já detectada anteriormente (cf. 1.6) nas fontes sobre o pitagorismo: aquela política, isto é, de uma koinonía que se apresenta como uma cidade dentro da cidade, alternativa aos modos de

${ }^{81}$ Orig.:"Something related to the Orphism - afirma Burkert (1972: 132) - had emerged from the anonymity of back-alley ritual to become respectable".

${ }^{82}$ Cf. Casadesús, apud Bernabé (2011, cap. 8). 
vida políades. A experiência política, religiosa e filosófica que uma concepção da alma como esta pressupõe vai em direção a uma quebra da ordem, à definição de uma alternativa decididamente contracultural. De fato, a descrição do indivíduo pela história pregressa de sua alma imortal contrasta diretamente os critérios biológicos e sociais que normalmente o definem no interior da pólis. Não mais a descendência sociobiológica, e sim a história das vidas anteriores determina seu lugar na sociedade. E essa história depende exclusivamente de sua responsabilidade ética. ${ }^{83} \mathrm{~A}$ consequência disso é o surgimento de comunidades e formas de vida relativamente autônomas e claramente sectárias no interior da estrutura social tradicional. Não acaso as mulheres encontravam nesses movimentos não somente uma franca acolhida, como, em certos casos, até mesmo lugar de destaque. Assim, por um lado, a saída radical proposta para o ser humano preso ao tempo e ao corpo "cidadãos" é a de uma eternidade sem corpo, resultando na definição escatológica de uma vida eterna e bemaventurada da alma. Por outro lado, a saída política é a mudança de estilo de vida, na qual o corpo esteja inserido profundamente em outra cidade, a koinonía dos "ouvintes", com suas prescrições morais próprias e, em muitos casos, bastante distintas daquelas poliades. ${ }^{84}$

Assim, a apropriação moralizante das teorias da imortalidade da alma platônica parece apontar diretamente para a sua derivação do ambiente pitagórico aristocrático e intelectualista da Magna Grécia a ele anterior e/ ou contemporâneo, tornando, dessa forma, Platão uma das fontes de difusão dessas mesmas teorias. Ao mesmo tempo, a metempsicose constitui um dos eixos centrais de sua ética e de seu projeto político de converter as almas para construir uma outra cidade.

Não deve fugir da atenção o fato de que, já no texto do Mênon (81a-c) acima citado, a metempsicose possui lugar central também para sua teoria do conhecimento, de maneira especial por causa da anamnese. Ainda que de forma menos contundente, mesmo esta segunda apropriação das teorias da imortalidade órficas revelará a marca de forte mediação pitagórica.

O exercício da memória é de fato central para a definição do lugar próprio do pitagorismo no interior das tradições órficas. A reforma do orfismo em sentido pitagórico à qual se fazia referência no capítulo primeiro - tese proposta

${ }^{83}$ Ainda paradigmáticas, neste sentido, as palavras de Cornford (1922: 141): "what is new in transmigration is the moral view that reincarnation expiates some original sin and that the individual soul persists, bearing its load of inalienable responsibility, through a round of lives, till, purified by suffering, it escapes for ever. [...] The individual becomes a unit, an isolated atom, with a personal sense of sin and a need of personal salvation, compensated, however, by a new consciousness of the soul's dignity and value, expressed in the doctrine that by origin and nature it is divine. [...] But only on condition of becoming pure". Menos convincentes, por outro lado (pace Casadio, 1991: 142-143), as ilações de Cornford sobre pretenso monismo e dualismo filosófico embutidos nestas mesmas teorias da metempsicose.

${ }^{84}$ Cf. para essa discussão Detienne (1963), Vegetti (1989), Federico (2000). Especialmente interessantes as observações de cunho histórico-antropológico sobre as "políticas da imortalidade" pitagóricas em Redfield (1991). Já dediquei a esta questão algumas páginas recentemente (Cornelli 2009a). 
por Pugliese Carratelli (2001: 17-29) e aqui já diversas vezes lembrada estaria exatamente fundamentada no exercício da memória no sentido de lembrar da origem divina e imortal da alma, e, a partir disso, compreender os princípios cósmicos e éticos do viver. Conforme vimos acima no testemunho de Empédocles (31 B129 DK), a memória das vidas anteriores é uma das características centrais do sábio pitagórico. O próprio Pitágoras teria construído sobre esta especial capacidade de recordar a historía de suas metempsicoses grande parte de sua fama. Anota com razão, neste sentido, Sassi que:

Pitágoras desenha sua imagem de sapiente exatamente se apresentando como aquele que, graças à experiência de muitas vidas, acumulou conhecimentos extraordinários. Esta imagem torna-se não somente fator de forte agregação da comunidade em torno de seu líder [...], mas também uma garantia da validade de novo saber, focado na descoberta fundamental, realizada pelo próprio Pitágoras, da harmonia de proporções numéricas que rege o cosmo (Sassi 2009: 180). ${ }^{85}$

De fato, a essa dimensão sapiencial da memória deveria corresponder um uso - por assim dizer - cotidiano dela, no interior das comunidades protopitagóricas: o membro da koinonía - segundo lembra Jâmblico - dedicava o primeiro tempo do dia para o exercício da anamnese:

O pitagórico não se levantava da cama antes de ter chamado novamente à memória o que havia acontecido no dia anterior. E procedia desta forma à anamnese: tentava chamar à mente a primeira coisa que havia dito, escutado ou ordenado aos domésticos no dia anterior, logo após ter acordado, e a seguir a segunda e a terceira; e procedia da mesma forma para as sucessivas (Iambl. VP: 165).

Como também devia marcar as comunidades pitagóricas um especial culto à deusa Mnemosýne, bem representado por um grupo de lâminas órficas que Pugliese Carratelli (2001: 27) chama exatamente de mnemosýniae. Nessas lâminas, é normalmente a deusa Mnemosýne, rainha das musas, à qual é dedicado o lago do além-túmulo, a ditar as senhas, as instruções que abrem ao iniciado as portas do além-túmulo. A senha é normalmente constituída por uma fórmula de apresentação, um sýmbolon: "sou filho da terra e do céu estrelado", conforme a célebre lâmina de Hipponion:

Este é consagrado a Mnemosýne. Quando irás para as bem construídas moradias do Hades [...] encontrarás a água fresca que corre do lago da Memória. $\mathrm{Na}$ frente desta estarão os guardas, que te perguntarão porque estás percorrendo

${ }^{85}$ Orig.: "Pitagora disegna la propria immagine di sapiente proprio presentandosi come colui che, grazie all'esperienza di molte vite, há accumulato conoscenze straordinarie. Questa immagine diventa non solo un fattore forte di aggregazione della comunità intorno al suo lider [...], ma uma garanzia di validità di um sapere nuovo, centrato sulla scoperta fondamentale, da parte dello stesso Pitagora, dell'armonia di proporzioni numeriche che regge il cosmo". 
as trevas obscuras do Hades. Diz: "sou filho da terra e do céu estrelado, de sede estou ardendo e desfaleço: deem-me logo para beber a água fresca que vem do lago da Memória". ${ }^{86}$

Prova dessa ligação do pitagorismo não somente com a prática da memória, mas com a mesma deusa Mnemosýne, é o testemunho dos Theologumena Arithmeticae, texto proveniente da primeira Academia e que se refere provavelmente a tradições de Espeusipo, atestando que os pitagóricos chamavam Mnemosýne a mônada e Mnême ou Pistis a década (44 A 13 DK). ${ }^{87}$

A insistência sobre a memória e a necessidade da anamnese parece definir, portanto, para as tradições pitagóricas, lugar distinto e especial no interior da religião órfica antiga. $O$ destaque para a necessidade de não esquecer, de recordar, está intimamente ligado, de um lado, a uma prática científica que encontra na memória sua técnica, seu ritual específico de erudição; por outro lado, a uma verdadeira tensão espiritual (representada nos fragmentos órficos como uma estrada que se divide em duas e que conduz a dois lagos diferentes: o da Memória e o do Esquecimento) que deseja levar o iniciado a sair do contínuo transmigrar, de existências em existências diferentes por meio da memória de sua verdadeira origem. ${ }^{88}$

Em conclusão, Platão, mesmo no uso da metempsicose para fundamentar sua teoria do conhecimento anamnética, revela suas dívidas para com o orfismo, e, de maneira especial, para aquele blending filosófico que o pitagorismo deve ter desenvolvido a partir do primeiro. ${ }^{89}$

${ }^{86}$ A lâmina constitui o mais antigo testemunho de uma fórmula bastante comum entre as lâminas da Magna Grécia e Creta. $\mathrm{O}$ mesmo texto é de fato presente também nas lâminas de Petélia, Entella e Pharsalos e Eleutherna. Cf. Pugliese Carratelli (2001: 39ss.) e Tortorelli Ghidini (2006: 62ss.).

${ }^{87}$ Cf. Burkert (1993: 359ss.) para um comentário ao testemunho de Filolau.

${ }^{88} \mathrm{~A}$ imagem dos dois caminhos não pode não lembrar o Prólogo do Poema de Parmênides, neste sentido. A deusa que encontra o filósofo foi identificada por diversos comentadores como a própria Mnemosýne. Já discuti anteriormente esta atribuição e as consequências dela para a interpretação do Poema: cf. Cornelli (2007b).

${ }^{89}$ Surpreendentemente, Burkert (1972: 214) considera um equívoco a relação entre Platão e os pitagóricos no que diz respeito à anamnese: "A closer look reveals that the connection of Pythagoras with Plato, in relation to anamnesis, is scarcely more than an equivocation". Os motivos deste ceticismo estão ligados ao fato de não considerar que a metempsicose tenha de fato alguma relação com as provas matemáticas que a página do Mênon (80d) em questão salienta. Ainda que isso seja procedente, a prática da anamnese como exercício da memória das vidas anteriores, em Platão, é ainda assim dificilmente separável das práticas e teorias da imortalidade de matriz órfico-pitagórica. 


\subsection{Heródoto, Isócrates e o Egito}

As referências de Heródoto à metempsicose pitagórica representam também testemunhos preciosos por serem originárias de outro âmbito intelectual diferente daquele da filosofia antiga e seus debates. A começar pelo célebre passo das Histórias em que se faz referência às crenças egípcias sobre a imortalidade:

Nisto também os egípcios foram os primeiros, isto é, no afirmar que a alma do homem é imortal e que entra, quando o corpo morre, no corpo de outro animal que nasce e que depois de ter transmigrado assim por todos os animais da terra, do mar e do ar, entra no corpo de um homem que nasce: a volta completa - dizem - (a alma) cumpre no espaço de três mil anos. Esta foi a doutrina acolhida por alguns gregos, uns mais cedo, outros mais tarde, e que a consideravam como sua. Eu mesmo conheço seus nomes, mas não vou escrevêlos (Herodt. Hist. II: 123).

Várias hipóteses foram levantadas para explicar a reticência de Heródoto. A mais comum é a de referir o silêncio de Heródoto ao medo dos círculos órficos da Magna Grécia se voltarem contra ele, por estar fazendo derivar do Egito uma doutrina como esta que os próprios órficos - cf. Heródoto "consideravam como sua" (Timpanaro Cardini 1962: III, 21-22).

Todavia, a hipótese não é muito convincente, ao menos por três motivos. Primeiramente, Heródoto cita explicitamente órficos e pitagóricos em outra passagem, estritamente relacionada a esta, na qual tece algumas considerações sobre os usos sepulcrais dos egípcios (que sepultavam os mortos em vestes de linho e não de lã, como na Grécia). Ele afirma que "tal [costume] corresponde aos chamados orfiká e bakchiká, que, na verdade, são egípcios e pitagóricos" (Herodt. Hist. II, 81). Aqui, ao contrário, a anterioridade de uma prática egípcia ligada à imortalidade é afirmada sem reticências. ${ }^{90}$

Em segundo lugar, conhecendo a ironia de Heródoto e seu gosto pelo “jogo”, não é difícil pensar que não escrever os nomes dos autores, nesse caso em que deveria ser evidente a todos a quem ele se estava referindo, pode ser uma remissão jocosa ao silêncio iniciático em relação às doutrinas e práticas

${ }^{90}$ A passagem não merece ulteriores considerações, pois a discrepância entre duas famílias de manuscritos, a romana (AB) e a florentina (RVS), fez praticamente todos os comentadores

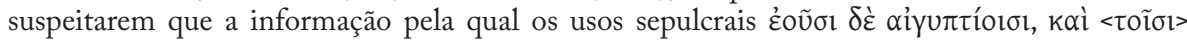
ПuӨ $\propto$ үo (1932: 189); Rathmann (1933: 52ss.) Timpanaro Cardini (1958-62: 22). Burkert (1972: 127ss.) argumenta - sem convencer totalmente - a favor da versão florentina e conclui com razão que esta última apontaria para uma conexão ritual entre pitagorismo e orfismo. Ainda que relevante, portanto, para a discussão da relação entre orfismo e pitagorismo, o valor de testemunho de Heródoto da passagem é esvaziado pela possível emenda da referência exatamente ao pitagorismo. 
órfico-pitagóricas e, de maneira especial, à ordem de não escrevê-las. ${ }^{91}$ Heródoto não faz questão de esconder essa mesma ironia em outro trecho das Histórias $(I V, 95)$ em que se refere a essas teorias órfico-pitagóricas da imortalidade e no qual narra, muito divertidamente, as façanhas de Zalmoxis, que foi servo de Pitágoras. Analisaremos essa última passagem nas páginas a seguir, em relação às tradições sobre as lendas que se referem à metempsicose.

Em terceiro lugar, se é verdade que Heródoto, junto com seus concidadãos, havia colonizado, em meados do século V a.C, a cidade de Thurii (já Sibari), na Itália meridional, reduto de longa tradição pitagórica, essa mesma colonização não deve ser compreendida como movimento filo-pitagórico. Ao contrário, a intervenção de Atenas veio resolver as sucessivas stáseis que a dominação pitagórica sobre a cidade havia criado, tornando Sibari autônoma politicamente desta dominação, e, de certa maneira, daqui para frente, antipitagórica..$^{92}$ Não seria, portanto, razoável imaginar que Heródoto devesse temer criar inimizades para si, por demonstrar postura antipitagórica, como a própria ironia com que trata o movimento em seus testemunhos parece indicar.

Uma série de hipótese de interpretação de quem seriam esses "alguns gregos", de maneira especial "aqueles que mais cedo aderiram à teoria", é levantada ao longo da história da crítica. Podem ser resumidas fundamentalmente três tipos de soluções: a) Pitágoras e Empédocles; b) órficos e Pitágoras; c) órficos e Empédocles. ${ }^{93}$ Contudo, o fato certamente mais significativo seria que os egípcios não teriam conhecido nenhuma teoria da imortalidade da alma. ${ }^{94}$ Esta informação errada causa estranhamento, pois Heródoto demonstra, ao contrário, conhecer bem as práticas egípcias da imortalidade. Isso faz Burkert imaginar tratar-se aqui de uma projeção de ideias gregas sobre os egípcios. ${ }^{95}$

Todavia, a ligação do pitagorismo com o Egito é afirmada em um fragmento do orador Isócrates, já citado no cap. 1, no contexto da definição da comunidade pitagórica pelo silêncio: "ainda hoje mais são admirados aqueles que se professam seus discípulos [de Pitágoras] e se calam, do que aqueles que obtêm grandíssima fama por meio da palavra” (Isócrates, Busiris $29=14$ A4 DK). A passagem completa é de fato introduzida pela referência às viagens de estudo que Pitágoras teria conduzido ao Egito:

${ }^{91}$ Cf. para esta discussão também Cornelli (2006).

${ }^{92}$ Para ampla discussão sobre a história de Sibari ao longo da dominição pitagórica sobre as cidades da Itália meridional, cf. Mele (2007: 240-247).

${ }^{93} \mathrm{Cf}$. para as referências bibliográficas completas Burkert (1972: 126 n38). Em resumo: a) Long (1948: 22); Kirk-Raven-Schofield (1983: 210ss.); b) Morrison (1956: 137), Casadio (1991: 128s), Zhmud (1997: 118ss.); c) Rathmann (1933: 48ss.).

${ }^{94}$ Cf. para isso já Zeller e Mondolfo (1938: 133), Kees (1956: 6), Burkert (1972: 126 n36) e agora Centrone (1996: 55).

${ }_{95}$ Burkert, ainda que com algum exagero em sua análise paleo-psicológica, chega a sugerir que o contexto imediato da passagem de Histórias II, 12, acima citada, poderia ter levado Heródoto a uma espécie de reminiscência das teorias da metempsicose, originárias do Sul da Itália. A passagem em questão é de fato precedida pela informação pela qual Deméter e Dioniso eram chamados pelos egípcios de donos do além-túmulo. Ambos, por sua vez, seriam cultuados no Sul da Itália (1972: 126 n37). 
Pitágoras de Samos, depois de chegar ao Egito e lá se tornar discípulo daqueles, foi o primeiro a apresentar outra filosofia aos gregos e distinguiu-se de maneira especial no que se refere aos sacrifícios e rituais nos santuários, considerando que, se com isso não ganharia mais vantagens por parte dos deuses, ao menos por meio disso obteria uma grande reputação entre os homens. Como de fato aconteceu. Sua fama foi assim tão superior à dos outros, que todos os jovens desejavam ser seus discípulos, e os anciões preferiam ver seus filhos com ele do que cuidando dos negócios familiares. É preciso acreditar nessas histórias, pois até hoje mais são admirados aqueles que se professam seus discípulos [de Pitágoras] e se calam, do que aqueles que obtêm grandíssima fama por meio da palavra (Isócrates, Busiris 28-29).

Dessa viagem ao Egito, portanto, Pitágoras teria trazido outra filosofia para os gregos. A terminologia e o contexto irônico ecoam tanto o sarcasmo de Heráclito como a ironia de Heródoto. Kahn anota justamente que um professor de eloquência como Isócrates não consegue "abster-se de dar uma cutucada" (refrain from a dig) ao silêncio pitagórico (Kahn 2001: 12). Da mesma forma, a expressão "é preciso acreditar nessas histórias" indicaria a postura geral de desconfiança em relação a essas tradições. ${ }^{96}$

${ }^{96}$ O valor do testemunho de Isócrates é, contudo, colocado em dúvida por Ries (1961), que detecta forte influência acadêmica sobre a tradição. 


\subsection{LENDAS SOBRE A IMORTALIDADE}

A mesma ironia é evidente na história de Zalmoxis lembrada por Heródoto (Hist. IV, 94-96): trata-se aqui da saga do deus trácio Zalmoxis, para o qual os Getas (que são definidos pelo historiador athanatizontas, "convencidos de serem imortais") acreditam irem os que estariam a ponto de morrer. Para este deus, realizam rituais de sacrifícios humanos, com a esperança de que o sacrificado entre em contato com o deus, obviamente após a morte. O contexto deste culto é evidentemente aquele das tradições da imortalidade da alma e do "journey model" acima citado, isto é, das viagens para o além-túmulo. Por esse motivo, provavelmente, Heródoto, após a descrição dos rituais sacrificiais, recorda uma lenda pela qual Zalmoxis teria sido, em verdade, servo de Pitágoras:

Liberto, ganhou grandes riquezas, e então voltou para sua pátria; mas como os trácios conheciam uma vida pobre e simples, o tal Zalmoxis, que havia conhecido o teor de vida dos jônicos e hábitos mais refinados daqueles dos trácios, pois havia frequentado os gregos, e entre eles não o mais insignificante, isto é, o sábio Pitágoras, filho de Mnesarco, mandou construir uma sala, e nela recebendo os dignatários a banquete, ensinava que nem ele mesmo, nem seus comensais, nem sequer os seus descendentes todos iriam morrer, mas que iriam para um lugar onde sobreviveriam e teriam todo tipo de benesses. Enquanto dizia e fazia isso que narrei, mandou construir uma casa subterrânea; quando ela foi completada, desapareceu da vista dos trácios, que se lamentavam e o choravam como se tivesse morrido. Mas após quatro anos Zalmoxis reapareceu na frente deles, confirmando dessa maneira o que ele havia afirmado (Herodt. Hist. IV: 95).

Para além do motivo etnocêntrico, que tende a diminuir a divindade dos Getas com a sugestão de que Zalmoxis, na Grécia, havia sido não somente um homem, mas até um escravo, a passagem de Heródoto revela-se, com todo o sarcasmo do qual o historiador é capaz, uma sátira das tradições ligadas à katábasis. A morte aparente de Zamoxis, de fato, não passa de um truque, na tentativa de convencer seus concidadãos de sua imortalidade. A remissão indireta aqui à figura de Pitágoras é certamente significativa: como a dizer que, ao falar de imortalidade da alma, ele é a referência imediata.

De fato, a temática da imortalidade e a figura carismática de Pitágoras, de certa forma, favorecem o surgimento de amplo leque de histórias legendárias a este respeito. ${ }^{97}$ Como é de se esperar, essas lendas não recolheram muito entusiasmo no interior da crítica atual, ainda que - é certamente o caso de concordar com Burkert (1972: 137) - correspondam de fato ao estrato mais antigo da tradição sobre Pitágoras, sendo anteriores a qualquer outra informação sobre a vida dele que encontramos em Aristóxeno ou Dicearco,

${ }^{97}$ Cf. para um estudo sobre as fontes das lendas de Pitágoras Lévy (1926). Uma discussão filosoficamente brilhante e filologicamente cuidadosa dessa literatura é também contida na excelente monografia de Biondi (2009) dedicada a Pitágoras-Euforbo. 
por sua vez fontes das Vidas pitagóricas de época imperial. Essa tradição lendária concentra-se especialmente em um tópico, que devia chamar bastante a atenção, que é aquele das efetivas metempsicoses de Pitágoras. Esse interesse pela história da alma de Pitágoras foi compreendido, já desde a antiguidade (Porph. VP: 26 e Diod. Sic. X 6,1) como uma exemplificação, na pele do fundador, da própria doutrina da transmigração da alma. Nesse sentido, parte da crítica moderna começou a considerar essa literatura como um testemunho da sua originalidade. ${ }^{98}$

A fonte mais significativa destas lendas é Heráclides Pôntico, um peripatético, que recorda a história da palingênese de Pitágoras assim:

Heráclides Pôntico refere que Pitágoras costumava dizer de si mesmo o seguinte: que uma vez havia sido Etálides, e que havia sido considerado filho de Hermes. O próprio Hermes teria lhe dito para pedir o que quisesse, fora a imortalidade. Ele então pediu para manter, tanto em vida como na morte, memória dos acontecimentos. Assim, quando vivo lembrava de tudo, e depois de morto conservava as mesmas lembranças. Algum tempo depois, foi para [o corpo de] Euforbo e foi ferido por Menelau. Euforbo, de sua parte, costumava dizer que uma vez havia sido Etálides, e tinha obtido este dom de Hermes, e narrava as peregrinações de sua alma, como transmigrou, e em quantas plantas e animais foi residir, e quantos sofrimentos a alma havia padecido no Hades. Morto Euforbo, sua alma transmigrou para Ermotimo, que, desejando dar uma prova disso, dirigiu-se para os Brânquides, e, entrando no templo de Apolo, soube indicar o escudo que Menelau havia pendurado como oferenda votiva (D. L. VIII. 4-5 // Heraclid. fr. 89 Wehrli).

A escassa probabilidade de Diógenes Laércio expungir a lenda diretamente de um diálogo de Heráclides Pôntico (pois não cita algum texto específico para isso) faz pensar em uma leitura doxográfica, isto é, de segunda mão, desta tradição. Por outro lado, diversas variantes da mesma genealogia da alma de Pitágoras são registradas na literatura antiga: em todas elas, o elemento comum é a reencarnação em Euforbo. ${ }^{99}$ Já Corssen (1912: 22) considerava esta presença de Euforbo incompreensível. Por qual motivo Pitágoras teria escolhido como etapa central da transmigração uma personagem tão secundária da história da guerra de Tróia? A resposta tradicionalmente dada, na esteira de Kerényi (1950), é que a figura de Euforbo estaria diretamente relacionada a Apolo, aliás seria uma espécie de encarnação dele (Burkert 1972: 141). De fato, Riedweg (2002: 51) e Biondi (2009: 67) concordam que Euforbo desempenha papel dramático decisivo no interior da trama da Ilíada: contribui para a morte de Pátroclo, que tem como consequência o retorno de Aquiles para a luta. Euforbo, ajudado e precedido por Apolo, que cansa e desarticula os membros de Pátroclo, desfere

${ }^{98}$ Cf. Riedweg 2006: 115. É também o caso de Timpanaro Cardini (1958-62: I, 5): "Pitagora crede nella metempsicose perchè crede nella sua metempsicose”, e de Burkert (1972: 147). De ideia contrária Rohde (1898: 422) que considera a memória toda fabulística.

${ }_{99}$ Cf. para as citações Delatte (1922: 154-159), Burkert (1972: 138-141), Federico (2000: 372 n.15) e Biondi (2009: 8-12). 
o primeiro golpe no guerreiro aqueu (Il. 16, 805-815). Seria, por consequência, esta estreita relação com Apolo a fazer pender a escolha para Euforbo. ${ }^{100} \mathrm{~A}$ prova disso é que o escudo de Menelau encontra-se, na tradição acima de Heráclides, no templo, mais uma vez, de Apolo. ${ }^{101}$

A escassa atenção às lendas sobre Pitágoras, como dizíamos, não deve fazer esquecer que, em relação a elas, nossa fonte mais importante é do século IV a.C: o próprio Aristóteles e seu livro sobre o pitagorismo (fr. 191 Rose). Nesse material, aparecem diversas lendas sobre milagres e prodígios operados por Pitágoras: as mirabilia incluíam experiências de ubiquidade, diálogos com um rio, adivinhação, e a significativa referência a Pitágoras como ao próprio Apolo. Esta investigação não permite uma análise exaustiva destas passagens aristotélicas, obviamente. É o caso de concordar, mais uma vez, com a cuidadosa análise de Burkert (1972:145) a esse respeito, pela qual essas lendas devem ser consideradas congruentes com o clima do século IV aEC, e que somente nos séculos sucessivos seriam usadas como motivo de chacota e crítica ao pitagorismo. $\mathrm{O}$ valor dessas tradições é ainda mais importante quando se considera a intenção geralmente demonstrada por Aristóteles de separar o protopitagorismo da sua platonização, operada pela Academia, que entre outras coisas - teria reduzido Pitágoras a um alterego do próprio Platão. ${ }^{102}$ $\mathrm{O}$ registro aristotélico das lendas teria autoridade, motivos e antiguidade suficientes para ser levado a sério. Em última análise, portanto, Pitágoras e sua lenda não podem ser separados. ${ }^{103}$

Entre todas as referências aos mirabilia, é ainda a temática da morte aparente a parecer estar bastante presente na literatura do período, se é verdade que a ela se faz referência na Electra de Sófocles: "Pois há muito tempo eu vi homens sábios que diziam, falsamente, terem morrido. E em seguida, uma vez voltados para casa, eram recebidos com grandes honras" (Soph. El. 62-64). O escoliasta anotava significativamente uma referência a Pitágoras ao lado desta passagem (Schol. In Soph. 62).

100 Centrone (1996: 64) anota com razão que o culto a Apolo era muito difundido nas cidades pitagóricas de Crotona e Metaponto. Cf. também Iambl. VP 52.

${ }^{101}$ Instigante, ainda que troppo alegórica, é também a leitura que Biondi (2009: 77) propõe da passagem da Ilíada acima citada: "è l'intervento di Euforbo che svela 1'identità autentica di colui che sembrava Achille: se l'armatura simboleggia il corpo, allora l'indifesa nudità rappresenta l'anima; dunque l'azione di Euforbo potrebbe effettivamente significare, al di là della lettera del testo omerico, lo svelamento dell'anima e la punizione della sua tracotanza”.

${ }^{102}$ Cf. Burkert (1972: 146), além do que foi dito acima (1.7) para o uso do pitagorismo no interior da polêmica antiacadêmica de Aristóteles.

${ }^{103}$ Cf. Burkert (1972: 120) para uma discussão metodológica da dificuldade que resulta desta afirmação. De ideia contrária Casertano (2009: 59), mas por considerar como lendas somente aquelas do segredo sobre as doutrinas e da estrutura da comunidade. 


\subsection{Demócrito PITAgóRICO?}

Ainda mais significativo é o testemunho de Demócrito nesse sentido. Descrito pelo contemporâneo Glauco de Régio como "discípulo de um pitagórico" (68 A1, 38 DK), o catálogo tetralógico de suas obras elaborado por Trásilo, na seção ética, é inaugurado pelas três obras seguintes: Pitágoras, Sobre a disposição do sábio e Sobre o Hades (68 B0a-c DK). Proclo ainda conhece o conteúdo desta última obra, na qual aparece novamente a temática da morte aparente:

Como é o caso de muitos outros filósofos antigos, entre eles Demócrito, o físico, nos escritos Sobre o Hades, narraram-se histórias sobre pessoas que pareciam mortas, mas que, ao contrário, voltavam à vida (68 B1 DK).

A própria sequência das três primeiras obras citadas aponta para alguma forma de dependência democritiana da ética pitagórica. É o que sugere já Frank (1923: 67) que - comentando a dedicação a Pitágoras de sua obra ética mais importante (não acaso citada por primeira) - acredita que isso se deva ao fato de Demócrito ter enxergado em Pitágoras fundamentalmente o fundador de uma seita ético-religiosa. ${ }^{104}$ Sem sermos obrigados a concordar "tout court" com Frank, é inegável a grande quantidade de aproximações possíveis entre a ética pitagórica e aquela democritiana. Os fragmentos democritianos $(68$ B84, 244 e 264 DK) sobre a necessidade "de sentir vergonha de si mesmo" pelas ações más remetem diretamente para a prática da anamnese, do exame de consciência de tradição pitagórica (Zeller e Mondolfo 1938: 335). Mais relevantes ainda seriam as aproximações em relação à questão da medida como base para o raciocínio ético (Riedweg 2002: 116). Todavia os paralelos podem não ser decisivos, se é verdade - como vimos acima - que esses mesmos conceitos de phrónesis, isonomia, métron acompanham o desenvolvimento da ética antiga e da tradição médica de maneira mais geral e difusa, não podendo, portanto, serem considerados - a bem ver - como marcos definitórios dos dois movimentos em questão.

No entanto, a aproximação entre atomistas e pitagóricos mais significativa para essa discussão sobre a imortalidade da alma pitagórica seria ainda aquela indicada por Aristóteles na passagem do De Anima, já citada (De an. 404a16), em relação a uma concepção material da alma pitagórica. Aqui é atribuída aos pitagóricos uma concepção corpuscular da alma ("as poeiras no ar"), quase a querer prefigurar a psicologia de Demócrito. Todavia, os problemas textuais

104 A economia destas páginas não permite avaliarmos detalhadamente as questões historiográficas implícitas nesta aproximação entre pitagorismo a atomismo. A questão será parcialmente enfrentada mais para frente, no âmbito da discussão sobre o atomismo numérico (4.1). Para uma crítica da posição de Frank, cf. Zeller e Mondolfo (1938: 332-333). Uma abordagem clássica à questão da relação entre pitagóricos e atomistas é a de Alfieri (1953: 30-54); para uma discussão mais recente sobre a leitura acadêmica pitagorizante de Demócrito cf. Gemelli (2007b: 42-58). 
acima apontados desencorajam a atribuição de grande importância a essa passagem. Além disso, na mesma página do De Anima, Aristóteles associa o movimento contínuo da poeira com a definição de alma como aquilo que move a si mesmo:

À mesma afirmação são levados também todos os que dizem que a alma é aquilo que move a si mesmo, pois todos eles parecem partir do pressuposto de que o movimento é algo muitíssimo peculiar à alma (De an. 404a 21-25).

Com a alma como aquilo que move a si mesmo, entra-se já em solo platônico, e mais precisamente xenocratiano. Não acaso, algumas páginas depois, quando a discussão das teorias sobre a alma dos predecessores alcança plenamente o âmbito acadêmico, afirma-se que "alguns sustentam que a alma é um número que move a si mesmo" (De an. 404b 29-30). Trata-se aqui sem dúvida da interpretação que Xenócrates (fr. 165 Isnardi Parente) elabora, em chave matemática e pitagorizante, da doutrina da alma de Platão como semovente (Phaedr. 245c-246a; Leg. X, 895). ${ }^{105}$

A maioria dos comentadores considera, portanto, a aproximação de $D e$ an. 404a16 um mal-entendido de Aristóteles, pois a imagem da alma como poeira em movimento estaria mais ligada a tradições místicas arcaicas do que a um diálogo que o pitagorismo estaria travando com o atomismo no século $\mathrm{V}$ aEC. Para Cherniss, a teoria da alma como poeira nada teria a ver com aquela do movimento:

Nesse caso, cada grão de poeira devia provavelmente ser considerado uma alma, de tal maneira que a psychén (sic) de Aristóteles implicaria complicações que não existem. [...] Uma teoria como esta, por não ter fundamentalmente nada a ver com os movimentos, deve corresponder a uma acomodação de uma superstição mais antiga com uma mais alta teoria física desenvolvida em tempos mais recentes (Cherniss 1935: 291 n.6). ${ }^{106}$

Philip (1966: 151), baseando-se na distinção que Aristóteles estaria fazendo entre "alguns pitagóricos" (tínes), que pensam a alma como poeira e outros (acadêmicos pitagorizantes?), diversamente destes, que sustentam que seria a alma "o que faz com que as poeiras se movam", imagina ser possível que Aristóteles estivesse aqui pensando, no caso dos primeiros, aos pitagóricos do século $\mathrm{V}$ a.C que teriam acomodado sua teoria da alma ao atomismo

${ }^{105}$ Cf. especialmente Isnardi Parente (1971: 166s), com a qual concorda Gemelli (2007: 57).

106 Orig.: "In this case each speck of dust was probably considered to be a soul, so that Aristotle psychén (sic) implies complications which did not exist. (...) Such a theory, since fundamentally it has nothing to do with the motes, must have been an accommodation of the earlier superstition to the more hightly developed psychical theories of later times". Ainda que sem o ranço positivista de Cherniss (evidente em expressões como earlier superstition), concordam com ele Rathmann (1933: 18-19), Zeller e Mondolfo (1938: 554), Burkert (1972: 120), Guthrie (1962: 306), Alesse (2000: 397). Casertano (2009: 70) considera a concepção naturalista da alma como "incontestabilmente pitagorica". 
contemporâneo. A hipótese é todavia incompleta, pois restaria explicar, para que ela fosse plausível, por quais motivos esses pitagóricos sentiriam a necessidade de fazer essa acomodação. 


\subsection{Aristóteles e os mitos PitagóRicos}

A aproximação exposta acima da concepção pitagórica da alma com o atomismo constitui - na melhor das hipóteses - uma referência ao pitagorismo do $\mathrm{V}$ século a.C, na pior delas apenas um mal-entendido. Por esse motivo, ela não pode constituir testemunho aristotélico da teoria da alma protopitagórica.

Ainda assim, é do mesmo Aristóteles o testemunho filosófico provavelmente mais explícito da existência de uma doutrina da metempsicose pitagórica. Trata-se de uma passagem que pertence a algumas páginas seguintes do mesmo De Anima. A passagem revela a dificuldade de atribuir uma teoria da metempsicose coerente aos primeiros pitagóricos. É, inicialmente, dessa dificuldade que Aristóteles parece queixar-se: ${ }^{107}$

Estes [filósofos] se esforçam somente para indicar qual seja a natureza da alma, nada acrescentando sobre o corpo que deve recebê-la, como se fosse possível, segundo os mitos pitagóricos, que qualquer alma entre em qualquer corpo $(D e$ an. 407b 20-23).

De fato, ao longo do exame das doutrinas sobre a natureza e as propriedades da alma iniciado no capítulo II do livro II do De Anima, Aristóteles acusa a impropriedade de todas as teorias de seus predecessores: seja em relação à compreensão de quais sejam as propriedades específicas da alma, como - de maneira especial - por estes não terem prestado atenção à questão central, isto é, à relação entre alma e corpo. De fato, "os filósofos", isto é, seus predecessores, "conjugam" (synáptousin) ou "justapõem" (tithéasin) a alma ao corpo, sem explicarem a causa e os modos dessa conjunção ou justaposição (De an. 407b 13-17).

Portanto, os mitos pitagóricos mencionados na passagem constituiriam um dos exemplos mais significativos desse erro. O absurdo (átopon, v. 13) da explicação avançada, que é explicitamente referida tanto ao Timeu de Platão, como também a todas as teorias da alma anteriores (v. 13-14), é exemplificado plasticamente na imagem desenhada na passagem seguinte, pela qual:

[Estes] se expressam como quem dissesse que a arte do carpinteiro entrasse nas flautas. Ao contrário, a técnica deve se servir dos [seus] instrumentos, assim como a alma do corpo (De an. 407b 24-26).

A alma, na elegante imagem de Aristóteles, seria, portanto, uma arte. Como tal necessita de seu instrumento próprio, isto é, de um corpo. Ao contrário, portanto, do que os mitos pitagóricos sustentam, isto é, de que qualquer alma pode entrar em qualquer corpo.

${ }^{107}$ Centrone (1996: 105) sugere que esta queixa de Aristóteles deveria depender mais de omissões (ou de falta de coerência) no interior dos escritos que ele estava consultando, do que propriamente de uma falta de informações sobre a questão, que contrariaria os testemunhos de que estaria de posse de diversos escritos pitagóricos (2.3). 
Imediatamente ocorre pensar na metempsicose.$^{108} \mathrm{O}$ próprio movimento indicado pelo verbo endýesthai, "entrar" da alma no corpo, evoca a imagem da transmigração. ${ }^{109}$ Diversos comentadores, todavia, quiseram levantar algumas dificuldades em relação à intenção de Aristóteles de referir-se à metempsicose nesta passagem do De Anima 407b 20-23. A começar por Zeller, que percebe uma contradição, em relação àquela que devia ser a teoria da metempsicose pitagórica:

A teoria da alma que entra no recém-nascido da atmosfera circunstante com sua primeira respiração, casualmente e como for (katá toûs Pythagorikoûs mýthous, diz Aristóteles na passagem acima citada), contribui provavelmente para demonstrar seu defeito na conexão com a doutrina da transmigração; onde a reencarnação deve de alguma forma representar (como é dito no mito de $\mathrm{Er}$ ) uma consequência da vida anterior, exigindo assim uma correspondência entre o temperamento (krâsis) da alma e aquele do corpo no qual entra (Zeller e Mondolfo 1938: 562). ${ }^{110}$

De fato, a teoria da metempsicose implica responsabilidade moral em vida, seguida de um julgamento post mortem que contradiria a ideia de aleatoriedade representada pela repetição do adjetivo tychón ("qualquer alma em qualquer corpo"). ${ }^{111}$ A maioria dos comentadores, todavia, a começar por

${ }^{108}$ Esta teoria é chamada $\mu \tilde{u} \theta$ oc também em Platão (cf. acima: Gorg. 492e).

${ }^{109}$ Cf. para isso já Kranz (Diels-Kranz 1951 I, 504, 7-9).

${ }^{110}$ Orig.: "La teoria dell'anima che entra nel neonato dall'atmosfera circostante con il primo respiro, a caso e come càpiti (katá toûs Pythagorikoûs mýthous, dice Aristotele nel luogo sopra citato) viene probabilmente a mostrare in pieno il suo difetto nella sua connessione con la dottrina della trasmigrazione; dove la reincarnazione deve pur rappresentare (com'è detto nel mito di Er) una conseguenza della vita anteriore, ed esige quindi una corrispondenza fra il temperamento (krâsis) dell'anima e quello del corpo in cui entra". A referência à forma de entrada da alma no corpo inaugura uma tendência a compreender esta passagem à luz daquela anterior de 404a 16ss, em que a alma-poeira teria características corpusculares, conforme se discutiu acima. Cf. Timpanaro Cardini (1958-62: III, 213); Maddalena (1964:340-41); Guthrie (1962: 129 e 260).

${ }^{111}$ Concordam com Zeller tanto Rathmann (1933: 17s), como Maddalena (1954: 340) e Casertano (1987: 19s). Timpanaro Cardini também demonstra seu ceticismo em relação ao fato de a passagem referir-se à metempsicose, avançando, todavia, mais uma vez uma explicação original para isso. Segundo ela, o exemplo do marceneiro e das flautas indicaria inegavelmente que a passagem não poderia referir-se à metempsicose, e sim simplesmente a como deva ser compreendida a associação entre corpo e alma. O motivo é que não faria sentido que a arte do luthier fosse considerada por Aristóteles como separada da flauta, pois, para melhorar sua capacidade, isto é sua arte, o luthier precisa da flauta, assim como a alma do corpo (Timpanaro Cardini 1958-62: III, 214). Todavia Alesse (2000: 403 n23) anota com razão que a leitura de

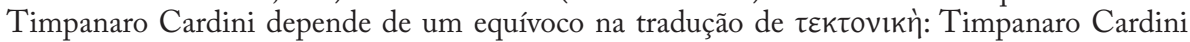
considera ser esta a arte do luthier, enquanto é mais plausível que Aristóteles se refira, neste caso, à arte do tocador de flauta, isto é, a flauta só pode ser utilizada por aquele que possui a arte de fazer funcionar à perfeição aquele instrumento, estaria dizendo aqui Aristóteles: seria este o flautista, portanto, não o luthier. Os termos da similitude são, contudo, bastante claros: de um lado, a arte e a alma, do outro, a flauta e o corpo; como o corpo em relação à alma, a flauta é a matéria que está predisposta a acolher a forma da arte (do flautista), e somente deste; não aquela do carpinteiro-luthier. Cherniss (1935: 325 n130) suspeita que a passagem possa referir-se mais precisamente à teoria platônica do Timeu da escolha do corpo após a primeira 
Burkert (1972: $121 \mathrm{n} 3)$, parece considerar que Aristóteles esteja se referindo, no caso específico, não a uma alma e um corpo individuais, e sim ao caráter geral da relação entre almas e corpos.

Algumas páginas depois, no mesmo De Anima, Aristóteles parece confirmar a crítica aos mitos pitagóricos de 407b, quando parece refinar a própria crítica, indicando que o problema estaria mais especificamente no fato de as almas poderem entrar em corpos diferentes:

Não é o corpo a realização da alma, mas esta aquela de determinado corpo. Por esse motivo, é correta a opinião daqueles que consideram que a alma não exista sem o corpo e tampouco que a alma seja um determinado corpo. Na realidade, não se identifica com o corpo, mas é algo de um corpo, e se encontra em um corpo de determinada natureza; não como acreditavam nossos predecessores, que a adaptavam a um corpo, sem indicar nem o que este seja nem suas qualidades, mesmo sendo evidente que jamais uma coisa qualquer recebe outra coisa qualquer (De an. 414a 18-25).

A crítica de Aristóteles deve ser obviamente compreendida no interior de sua teoria da alma como desenvolvida no De Anima, isto é, fundamentalmente, da teoria da alma como entelécheia do corpo, pela qual esta realiza as funções que potencialmente já estão na matéria que constitui o corpo. É consequentemente impensável que "uma coisa qualquer receba outra coisa qualquer", ecoando a mesma ideia expressa em $407 \mathrm{~b}$, pela qual "qualquer alma entre em qualquer corpo" (v. 23).

É mesmo o caso de pensar que a crítica de Aristóteles nas duas passagens seja dirigida à metempsicose pitagórica, pois o que Aristóteles devia considerar como problemático é a admissão da possibilidade de uma alma entrar em um corpo do qual não seja entelécheia; como seria o caso da transmigração de um corpo humano para um corpo animal, inferior ao primeiro. ${ }^{12} \mathrm{O}$ ataque aristotélico é aqui dirigido não somente à teoria da metempsicose, e sim também a uma teoria que a citação de Porfírio $(V P: 19)$ que abriu este capítulo considerava notoriamente pitagórica: a do parentesco universal, logicamente interdependente da primeira.

De toda forma, para esta investigação, pode-se concluir que a página 414a do De anima não somente remete especificamente à metempsicose, mas que é uma continuação da passagem 407b imediatamente anterior. Os mitos pitagóricos desta não poderão que ser compreendidos, portanto, como as teorias da metempsicose da alma.

vida, representando consequentemente mais uma polêmica antiplatônica do que uma posição antipitagórica. De toda forma, permanece na passagem a referência à metempsicose, que é o que mais diretamente interessa à nossa investigação.

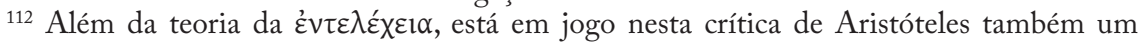
princípio de subsunção, pelo qual uma forma superior contém em si mesma a forma inferior, “como um quadrilátero contém o triângulo" (De an. 414b 31). O mesmo vale para as formas viventes, pois "o caso das figuras é semelhante àquele da alma" (De an. 414b 29). No entanto, o contrário não é verdadeiro, aliás, é absurdo (De an. 407b 13). 
Mais difícil - ainda que central para nossa discussão - é determinar se essas passagens de Aristóteles referem-se ao protopitagorismo, ou, ao contrário, ao pitagorismo a ele contemporâneo, de Filolau e Arquitas, por exemplo.

O termo mýthoi, utilizado para indicar essas doutrinas, é um sintoma de que Aristóteles as considerava antigas, mas não necessariamente destituídas de toda verdade. Prova decisiva disso é o fato de ele se dar ao trabalho de refutá-las. O âmbito semântico dos termos mýthos ou mythologeîn é frequentemente conectado, no interior da obra de Aristóteles, com aquele dos theológoi e do palaioi, a indicar não tanto uma diminuição do valor teorético das doutrinas, e sim mais precisamente sua invencível arcaicidade. A consequência disso é uma elaboração insuficiente dos argumentos lógicos e uma roupagem inadequada à maneira 'contemporânea' de fazer ciência. ${ }^{113}$ Como é o caso daquela página da Metafísica dedicada à ideia do divino que circunda a natureza:

Uma tradição em forma de mito foi transmitida aos pósteros a partir dos antigos e antiquíssimos, segundo a qual essas realidades são deuses, e o divino envolve toda a natureza. As outras coisas foram posteriormente acrescentadas para persuadir o povo e para fazê-lo submeter-se às leis e ao bem comum. De fato, dizem que os deuses têm a forma humana e que são semelhantes a certos animais e acrescentam a essas outras coisas da mesma natureza ou análogas. Se, de todas elas, prescindindo do resto, assumimos só o ponto fundamental, isto é, a afirmação de que as substâncias primeiras são deuses, é preciso reconhecer que ela foi feita por divina inspiração (Met. 1074b1-10). ${ }^{114}$

Portanto, o núcleo teorético da teoria, segundo Aristóteles, deve ser considerado como ainda válido. Como devia ser o caso dos mitos pitagóricos, que ainda que antigos, mereceram todavia suas considerações críticas nas passagens acima analisadas.

E bastante provável, portanto, que com a expressão mitos pitagóricos Aristóteles entenda referir-se a doutrinas dos primeiros pitagóricos. ${ }^{115} \mathrm{Uma}$ ulterior prova disso é que a expressão não é jamais utilizada para a discussão que Aristóteles faz da matemática pitagórica, que, como ver-se-á no próximo capítulo, atinge fontes do século $\mathrm{V}$ a.C, como Filolau, e que Aristóteles identifica, em Metafísica $A$, como os "assim chamados pitagóricos". ${ }^{116}$

${ }^{113}$ Cf. Met. 1074b1, 1091b9; Pol. 1269b28, 1341b3; De caelo 284a23. Aristóteles considera

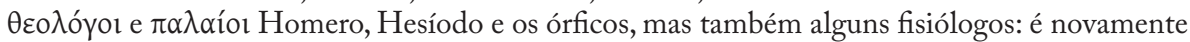
o caso dos pitagóricos, em Met. 1091a34-b12, que são chamados aqui de $\theta$ co $\lambda o ́$ yo no contexto de discussão sobre o um e a díade que retoma a discussão do livro $A$ sobre a questão em que os pitagóricos são claramente citados em oposição a Platão (Met. 987b14-988a8).

${ }^{114} \mathrm{~A}$ menos que não se indique diferentemente, a tradução das passagens citadas da Metafísica de Aristóteles será a de G. Reale/M. Perine (Aristóteles 2002), com algumas modificações.

${ }^{115}$ Cf. neste sentido Alesse (2000: 408).

${ }_{116}$ Para esta identificação das doutrinas pitagóricas da Metafísica A com o pitagorismo de Filolau cf. Burkert (1972: 236-238), Centrone (1996: 105), Huffman (1993). Veja-se também a resenha historiográfica do valor do testemunho de Aristóteles sobre Filolau acima esboçada, ao longo do capítulo primeiro. 
Outro marco lexical dessa antiguidade é o verbo utilizado por Aristóteles na passagem do De anima 407b 20-23 para indicar a metempsicose: endýomai, "entrar" (da alma no corpo). O mesmo verbo é utilizado por Heródoto para descrever a transmigração da alma, na passagem acima citada, em que a origem da teoria da metempsicose é indicada como sendo egípcia (Herodt. II, 123). Em Platão, o verbo é usado em duas passagens para indicar a metempsicose de uma alma que estava em um homem e entra em um animal: "um burro ou alguma besta deste tipo" (Phaed. 82a) ou "em um macaco", no caso da alma do ridículo Tersites, no interior do mito de $\operatorname{Er}(R e s p . X, 620 \mathrm{c})$. As duas passagens platônicas ilustram precisamente aquilo que Aristóteles devia temer como absurda consequência da teoria de metempsicose: a possibilidade da entrada de uma alma humana no corpo de um animal inferior. ${ }^{117}$

O léxico aristotélico da passagem sugere, portanto, que ela possa remeter a tradições antigas da teoria da metempsicose, que Aristóteles chama de "mitos pitagóricos", provavelmente reconhecendo no protopitagorismo a fonte dessas doutrinas sobre a imortalidade da alma e sua transmigração. Aristóteles torna-se com isso uma das fontes mais confiáveis para a atribuição da teoria da metempsicose aos pitagóricos mais antigos.

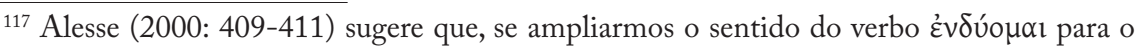
âmbito semântico do vestir, que também lhe pertence, o verbo apontaria imediatamente para uma ampla série de imagens do corpo como veste da alma, presente tanto nos escritos platônicos (Phaed. 86e-88b) como no fr. 126 de Empédocles. Veste que acaba por ter o sentido também de tumba, no interior da tradição do corpo como tumba da alma, próximo à sensibilidade órfica. 


\subsection{Conclusão}

Partindo de um testemunho de Porfírio sobre as doutrinas centrais de Pitágoras, analisou-se aqui a tradição da teoria da imortalidade da alma e sua metempsicose, com a intenção de, por um lado, verificar se ela poderia ser reconduzida à prática e à doutrina do protopitagorismo; por outro lado, compreender em que medida contribuiu para a definição da categoria pitagorismo ao longo da história. Os testemunhos mais antigos a atribuírem esta doutrina a Pitágoras sugeriram dois diversos percursos hermenêuticos. Primeiramente, ainda que antiga, a teoria da imortalidade da alma, por sua própria natureza apocalíptica, não implica a existência de um sistema dogmático de crenças. O que equivale a dizer que, ao longo dos diversos estratos da tradição pitagórica, as concepções dessa imortalidade deviam diferenciar-se até significativamente. Em segundo lugar, por consequência do primeiro percurso, identificou-se ser preciso verificar de que maneira a recepção da teoria por parte das suas fontes mais tardias contribuiu para a construção, por meio dela, da categoria pitagorismo. Os testemunhos de Xenófanes, Heráclito, Íon e Empédocles revelam, ainda que com tonalidades diferentes, uma característica incomum da figura histórica de Pitágoras, ligada fundamentalmente à sua capacidade de reconstruir a história psicológica do indivíduo, isto é, de definir os movimentos da metempsicose da alma em sua palingênese. Esses testemunhos sugerem que a metempsicose deveria ser uma teoria já bastante antiga, correspondente ao estrato protopitagórico.

Platão e sua obra foram identificados como lugares decisivos para o exercício dos dois percursos hermenêuticos acima apontados. De maneira especial, por trazer à tona a vexata quaestio das relações entre pitagorismo e orfismo. O estudo das referências a este segundo movimento na obra platônica, de maneira especial nas páginas que dizem respeito às teorias da imortalidade da alma, delineou um esquema historiográfico preciso, pelo qual Platão estaria atingindo a teorias órficas, sim, mas mediadas pelo pitagorismo. Pressuposto desta tese é que o pitagorismo seja considerado à maneira de um movimento reformador, em sentido intelectualista e aristocrático, do orfismo como tal. Sinal inequívoco desta mediação pitagórica é a moralização da metempsicose. Tanto a proposta platônica de uma hierarquia das encarnações, como também sua etimologia, antes semântica e depois soteriológica, do mote órfico sômasêma, apontam para uma dependência, em sua obra, da transposição das teorias da imortalidade da tradição pitagórica. Dessa forma, também Platão torna-se fonte confiável da existência de uma teoria protopitagórica da alma e de uma relação estreita entre esta mesma teoria e seu caldo de origem órfico. Relação esta que foi descrita como de exegese "mito-lógica" que o pitagorismo operaria sobre as tradições órficas, à maneira do papiro Derveni. Ainda que central para a própria concepção ética de Platão, não deve ser diminuída a importância da imortalidade da alma e de sua metempsicose mesmo para sua teoria do conhecimento: a anamnese, ligada fundamentalmente ao exercício da memória, 
remete diretamente para as práticas da "historía" da alma e do conhecimento de sua palingênese, que, como se dizia acima, são atribuídas a Pitágoras já por testemunhos a ele contemporâneos. Em suma, Platão, revelando suas dívidas para com o orfismo, acaba por apontar diretamente para aquele blending filosófico que o pitagorismo deve ter desenvolvido a partir do primeiro.

Enquanto os testemunhos de Heródoto, Isócrates, Demócrito e as lendas sobre a imortalidade e as mortes aparentes não permitem sólidas conclusões do ponto de vista filológico e historiográfico, encontra-se em Aristóteles o testemunho mais explícito da existência de uma teoria protopitagórica da metempsicose. Em síntese, o uso do termo mýthoi para referir-se a estas doutrinas pitagóricas da alma sugere que Aristóteles as considerasse suficientemente antigas, e, portanto, com toda probabilidade protopitagóricas. O léxico aristotélico acaba por apontar no protopitagorismo a fonte das doutrinas sobre a imortalidade da alma e sua transmigração: de fato, em relação às doutrinas matemáticas, que dizem respeito a outro momento do pitagorismo, aquele normalmente identificado por Filolau e Arquitas, no V século a.C, Aristóteles não se refere jamais a mitos.

É a essas doutrinas matemáticas, ilustres ausentes no resumo das doutrinas mais célebres de Porfírio, com o qual começamos este capítulo, que dedicaremos nossa atenção no quarto e último capítulo.

Antes disso, é certamente o caso de anotar aqui que atribuir uma teoria da metempsicose ao protopitagorismo significa, do ponto de vista filosófico, muito mais do que simplesmente reconhecer um diálogo deste último com a cultura órfica de seu tempo.

Pois, em si mesma, a teoria da transmigração da alma imortal pressupõe o outro argumento citado pelo resumo inicial de Porfírio, isto é, a teoria do parentesco universal. ${ }^{118}$ Essa teoria já está implicada também no fragmento de Empédocles acima citado (31 B129 DK) e constitui não somente consequência lógica da própria teoria da metempsicose, mas representa uma lei geral do funcionamento do cosmo, que abraça o passado e o futuro, seres humanos e outros seres viventes, em uma explicação que quer ser única e coerente do funcionamento da vida no universo. Essa doutrina, por ter os atributos de uma explicação totalizante e estar baseada em uma concepção do cosmo e da vida como eternos, pode certamente ser considerada como uma genuína expressão daquele período da história da filosofia que se convencionou chamar de pré-socrático.

${ }^{118}$ Cf. Delatte (1992: 175) para as citações desta doutrina no interior da literatura antiga. 
PARte IV

Números 
A passagem de Porfírio citada anteriormente com a qual começou o terceiro capítulo, resumindo aquelas que a tradição passará a considerar como doutrinas centrais do protopitagorismo, concentra-se quase que exclusivamente nas teorias da imortalidade. Não se faz nenhuma referência ao outro grande âmbito doutrinário cuja origem a tradição atribui ao pitagorismo, isto é, aquele da matemática.

A ausência dessa referência é significativa para a compreensão dos caminhos de definição de uma categoria historiográfica, como aquela do pitagorismo, que, ao contrário, depende amplamente dessa ligação com os números. Ela sugere a necessidade de uma consideração mais atenta da história da atribuição ao pitagorismo antigo de uma teoria matemática ou de alguma relação com o estudo dos números.

Como no caso do capítulo terceiro, dedicado às teorias da imortalidade, as páginas a seguir serão tecidas a partir, de um lado, da busca por um complexo doutrinário que corresponda a uma teoria dos números pitagórica; por outro lado, acompanhando a construção da categoria do pitagorismo a partir da tradição de seu interesse pela matemática em geral.

Não por acaso, conforme se anotava anteriormente, no interior da discussão sobre o testemunho único de Aristóteles (1.7), a tradição interpretativa, certamente encabeçada em tempos mais recentes por Frank (1923), acostumou-se a considerar toda a matemática pitagórica como uma invenção acadêmica, posterior, portanto, aos mesmos fragmentos de Filolau, que devem, eles mesmos, ser considerados espúrios. Como será visto ao longo destas páginas, a solução para a questão central aqui proposta dependerá exatamente de uma reavaliação dos fragmentos de Filolau, tanto do ponto de vista historiográfico, isto é, do lugar que o testemunho destes representa para a definição da categoria pitagorismo, como também do ponto de vista teorético, isto é, de qual seja a matemática neles contida.

Longe da confiança que Zeller depositava na possibilidade de resumir as doutrinas do pitagorismo na teoria pela qual o número seria a essência de todas as coisas (junto com as doutrinas da harmonia, do fogo central e das esferas), todas elas significativamente presentes nos fragmentos de Filolau, a crítica contemporânea submeteu a uma profunda revisão o pretenso dogma aristotélico pelo qual, no pitagorismo, "tudo é número". ${ }^{1}$ A influência do ceticismo de Franké tamanha ao ponto de alguém como Cherniss (1935), que conforme se verificou anteriormente - diverge dele na concepção fundamental do valor a ser atribuído ao testemunho de Aristóteles, concordar, ao invés, neste ponto com o primeiro. $\mathrm{O}$ consenso dos comentadores é especialmente impressionante quando diz respeito àquele que consideramos como um dos

\footnotetext{
${ }^{1}$ Cf. para isso 1.1 .
} 
loci fundamentais desse debate, isto é, o valor a ser conferido aos fragmentos de Filolau:

Os fragmentos atribuídos a Filolau são certamente espúrios, por eles conterem elementos que não podem ser mais antigos que Platão. Erich Frank reuniu as evidências contra os fragmentos; e, apesar de sua própria teoria sobre suas origens e a conclusão de argumentos certamente muito fracos [...], sua análise torna supérfluo ter de recomeçar o devastante caso contra eles (Cherniss 1935: $386) .^{2}$

Mais recentemente, a posição de Frank, e da grande maioria dos comentadores, recebeu profunda revisão crítica, por parte de autores como Burkert (1972: 238-277) e Kirk, Raven e Schofield (1983: 324). Especialmente significativos, nesse sentido, são os esforços de Huffman, tanto em seu artigo de 1988 quanto, especialmente, em sua monografia inteiramente dedicada a Filolau e aos problemas da autenticidade de seus fragmentos (1993): a primeira inteiramente dedicada ao filósofo de Crotona depois da monografia de Boeckh de $1819 .{ }^{3}$ Essa revisão abre novas perspectivas hermenêuticas e, junto com os recentes estudos de Zhmud (1989; 1997), representa uma pedra angular para a definição do lugar da matemática na construção da tradição pitagórica. ${ }^{4}$

${ }^{2}$ Orig.: "The fragments attributed to Philolaus are surely spurious, since they contain elements that cannot be older than Plato. Erich Frank has gathered the evidence against the fragments; and, apart from his own theory as to their origin and his conclusion of certain very weak arguments [...] his analysis makes it superfluous to restate the overwhelming case against them".

${ }^{3}$ Para uma geral concordância dos comentadores com o ceticismo de Frank, cf., entre outros, Burnet (1908: 279-284) e Lévy (1926: 70ss.). Não é certamente o caso de concordar, portanto, com Spinelli (2003; 145 n345), quando "despacha” a questão da autenticidade dos fragmentos desta forma: "apesar do muito que já se escreveu a favor e contra eles, toda a argumentação se encontra exposta, de um modo adequado, somente nos trabalhos de três tratadistas": Bywater, Frank e Mondolfo.

${ }^{4}$ A bem da verdade, é o caso de ressaltar que o próprio Frank teria em seguida amenizado, em seus escritos sucessivos, uma posição que, por seu ceticismo extremo e, de certa forma, paralisador, não resistiu às críticas dos outros comentadores. De fato, em 1955, deverá admitir que "it can hardly be doubted that Pythagoras was the originator of this entire scientific development: he was a rational thinker rather than an inspired mystic" (1955: 82). Não obstante, em sua resenha do livro de Von Fritz sobre a política pitagórica, sua verve cética ainda aparece fortemente presente (Frank 1943). 


\subsection{Tudo É NÚMERo?}

\subsubsection{Três versões da doutrina pitagórica dos números}

A pergunta "Tudo é número?", que intitula significativamente o célebre artigo de Zhmud na revista Phronesis de 1989 ("All is number?"), inaugura uma contestação do testemunho aristotélico central para a historiografia do pitagorismo, segundo a qual "tudo é número" seria a definição fundamental da filosofia pitagórica. ${ }^{5}$ Tarefa esta não certamente fácil, especialmente quando se considera que tanto a história da filosofia antiga quanto aquela da matemática antiga não pareceram ter muitas dúvidas, até então, em relação a essa mesma atribuição. ${ }^{6}$

E os motivos para tal confiança aparentemente não faltam. Com efeito, em Aristóteles, a atribuição da doutrina do "tudo é número" aos pitagóricos recorre diversas vezes e acaba por resumir aquela que é a interpretação aristotélica do pitagorismo.

Aristóteles afirma repetidamente que:

1) Pensavam serem os elementos dos números os elementos de todas as coisas

2) e que a totalidade do céu é harmonia e número (Met. 986a3). ${ }^{7}$

3) Os números, conforme dissemos, correspondem à totalidade do céu (Met. 986a21). ${ }^{8}$

4) Eles dizem que os números são as próprias coisas (Met. 987b28). ${ }^{9}$

5) Aqueles [filósofos] dizem que as coisas são número (Met. 1083b17). ${ }^{10}$

6) Fizeram os números serem as coisas que são (Met.1090b23). ${ }^{11}$

Aristóteles, assim, por seis vezes, faz os pitagóricos afirmarem que a realidade como um todo (tá ónta, tón ólon oûranon, tá prágmata) "é número".

Em contrapartida, por outras sete vezes, Aristóteles parece sugerir que os pitagóricos digam algo levemente distinto:

1) "Não há outro número além do número pelo qual está constituído o mundo" (Met. 990a21). ${ }^{12}$

${ }^{5}$ Ainda que algumas sugestões nesse sentido já haviam sido formuladas por Huffman (1988), em seu artigo sobre o papel do número na filosofia de Filolau, as observações não foram declaradamente recebidas no artigo de Zhmud (1989: 292 n.62), pois este foi desenvolvido paralelamente ao artigo do primeiro. 57).

${ }^{6}$ Cf. para as citações, Heath (1921: 67), Guthrie (1962: 229ss.), Huffman (1988: 5 e 1993:

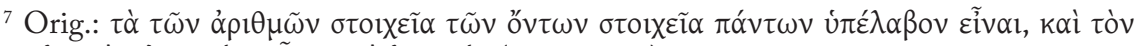

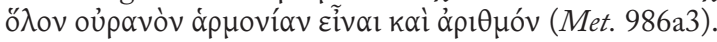

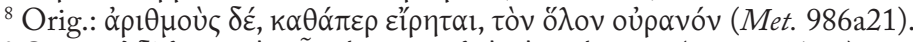

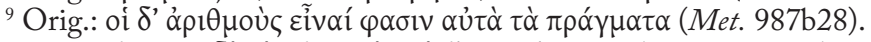

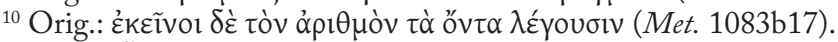

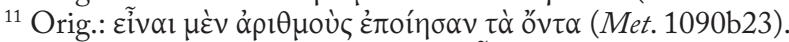

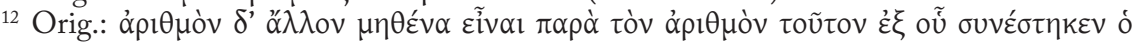

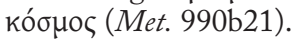


2) “Também para os pitagóricos só existe o número matemático: mas eles afirmam que este não é separado e que, antes, é dele que se sustentam as coisas sensíveis,

3) pois eles constroem o céu inteiro com números"(Met. 1080b16-19). ${ }^{13}$

4) "É impossível afirmar que [...] os corpos são feitos de números" (Met. 1083b11)..$^{14}$

5) "Fizeram os números serem as coisas que são, mas não de maneira separada, e sim de números são constituídas as coisas que são" (Met.1090a23-24). ${ }^{15}$

6) "Fazem derivar os corpos físicos dos números" (Met.1090a32). ${ }^{16}$

7) "Chegam ao mesmo resultado também aqueles que consideram que o céu é feito de números" (De caelo 300a16). ${ }^{17}$

Nas citações acima, o que Aristóteles faz os pitagóricos afirmarem, mais precisamente, é que a constituição do mundo se daria ex arithmôn, isto é, com os números como sua matéria constitutiva (e, portanto, imanente).

Essa variabilidade da lectio aristotélica marca toda sua abordagem ao pitagorismo (Burkert 1972: 45). A dificuldade que Aristóteles demonstra em sua tentativa de expressar, nos termos de sua filosofia, as doutrinas pitagóricas já foi notada anteriormente em relação à questão da alma (3.8). Não diferentemente, aqui a apresentação da doutrina do "tudo é número" por Aristóteles é, no limite, contraditória e apresenta basicamente três diferentes significados. ${ }^{18}$ Para além da primeira versão, que se refere à identificação fundamental dos números com os objetos sensíveis, duas outras versões são fornecidas por Aristóteles.

A segunda delas é a da identificação dos princípios dos números com os princípios das coisas que são:

Os assim chamados pitagóricos são contemporâneos e até mesmo anteriores a estes filósofos [Leucipo e Demócrito]. Eles por primeiros aplicaram-se às matemáticas, fazendo-as progredir e, nutridos por elas, acreditaram que os princípios delas eram os princípios de todos os seres (Met. 985b23-26).

Essa versão pode ser aproximada daquela de Met. 986a3 citada anteriormente, que no lugar de archai refere-se a stoichéia.

A terceira é a da imitação dos números pelos objetos reais, na célebre passagem em que é desenhado um paralelismo com a concepção platônica da participação:

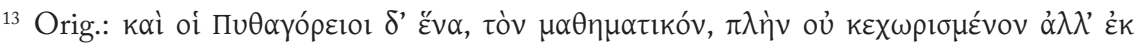

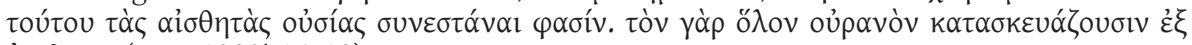
$\dot{\alpha} \rho 1 \theta \mu \tilde{\omega} \nu$ (Met. 1080b16-19).

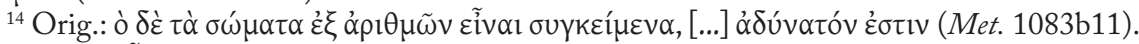

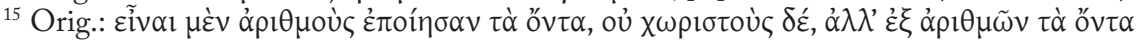
(Met.1090a23-24).

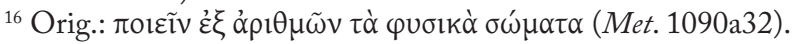

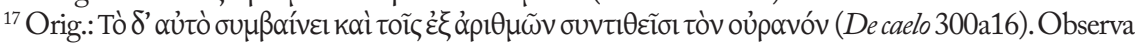
com razão Huffman (1988: 5 n.15; 1993: 57 n.2) que Aristóteles inclui, nestes, também os atomistas.

${ }^{18}$ Reproduzem essa mesma tripartição Cherniss (1935: 386), Zhmud (1989: 284-286) e Huffman (1993: 60). 
Os pitagóricos dizem que os seres subsistem por imitação dos números. Platão, ao contrário, diz por participação, mudando apenas o nome. De todo modo tanto uns como o outro descuidaram igualmente de indicar o que significa participação e imitação das ideias (Met.987b11-14).

A primeira versão, pela qual "os números são as coisas”, é evidentemente contraditória com as outras duas. Cherniss (1935: 387) anota, com razão, que Aristóteles procura conciliar esta primeira versão com a segunda, aqui citada, pela qual os números seriam princípios de todas das coisas. $\mathrm{O}$ sucesso de sua tentativa depende de ele forçar uma teoria da derivação da realidade do número um que, todavia, além de não existir como tal nas fontes, aparentemente confunde a cosmologia pitagórica com a teoria dos números (Cherniss 1935: 39). Tentativa, esta, que o próprio Aristóteles parece reconhecer como falimentar quando afirma:

Esses filósofos também não explicam de que modo os números são causas das substâncias e do ser. São causas enquanto limites das grandezas, e do mesmo modo como Eurito estabelecia o número de cada coisa? (Por exemplo, determinado número para o homem, outro para o cavalo, reproduzindo com pedrinhas a forma dos viventes, de modo semelhante aos que remetem os números às figuras do triângulo e do quadrado [...] (Met. 1092b8-13).

Com a referência a Eurito, Aristóteles introduz uma teoria que foi chamada de "atomismo numérico", pela qual os números seriam as coisas porque os números (pensados como pséphoi, pedrinhas) constituem a matéria pela qual as coisas são feitas. Com razão, de fato, anota Cherniss (1951: 336) que, dessa forma, os números poderão identificar qualquer tipo de objeto fenomênico:

Pensaram os números como grupos de unidades, sendo as unidades pontos materiais entre aquilo que é "sopro" ou um "vazio" material; e identificaram literalmente todos os objetos fenomênicos por meio de uma tal agregação de pontos, fossem eles divisíveis ou menos. Esta era mais uma materialização do número do que uma materialização da natureza, mas esta parecia indubitalvelmente aos pitagóricos a única maneira de explicar o mundo físico nos termos daquelas proposições genuinamente matemáticas que eles haviam provado serem independemente válidas (Cherniss 1951: 336). ${ }^{19}$

Tannery (1887b: 258ss.), Cornford (1923: 7 ss.) e o próprio Cherniss (1935, 387), fascinados pela primitividade do método atomístico-numérico de Eurito,

${ }^{19}$ Orig.: "Numbers they held to be groups of units, the units being material points between which there is 'breath' or a material 'void'; and they quite literally identified all phenomenal objects with such aggregations of points, without, of course, considering whether these material points were themselves divisible or not. This was rather a materialization of number than a mathematization of nature, but it undoubtedly seemed to the Pythagoreans to be the only way of explaining the physical world in terms of those genuinely mathematical propositions which they had proved to be independently valid". 
consideraram-no efetivamente antigo..$^{20}$ Todos seguem basicamente Frank (1923: 50) e sua hipótese pela qual a teoria teria sido emprestada por Arquitas do mesmo Demócrito. Não por acaso, a referência da citação de Met. 985b23-26 é a Leucipo e Demócrito, isto é, à tradição atomista, à qual a teoria pitagórica é aproximada. Além disso, foi vislumbrada na polêmica zenoniana contra a pluralidade exatamente uma referência ao atomismo numérico dos pitagóricos. ${ }^{21}$ Todavia, Burkert (1972: 285-288) e Kirk, Raven e Schofield (1983: 277-278) colocaram em sérias dúvidas essa atribuição. Os argumentos para isso não faltam..$^{22}$

Entretanto, não é difícil imaginar que a materialidade dos números pitagóricos possua um sentido mais arcaico, sem a necessidade de postular necessariamente um atomismo numérico. Sentido este bem resumido pela já clássica definição de Nussbaum:

A noção de arithmos é sempre conectada de forma muito próxima com a operação do contar. Para que algo seja um arithmos deve ser de tal forma que possa ser contado - o que em geral significa que ou possui partes distintas e ordenadas ou que seja uma parte distinta de um interior maior. Fornecer o arithmos de algo que há no mundo corresponde a responder à pergunta "quantos" deste. E quando o grego responde "dois" ou "três", ele não considera que esteja introduzindo uma nova entidade, e sim que esteja separando ou medindo as entidades que já estão em questão (Nussbaum 1979: 90). ${ }^{23}$

\section{O número seria, ainda, "ele próprio uma coisa" (Burkert 1972: 265). ${ }^{24}$}

Assim, a segunda concepção, acima citada, pela qual os princípios dos números seriam os princípios de todas as coisas, corresponderá mais facilmente àquela que Cherniss (1935: 390) define como uma "construção aristotélica da tese pitagórica". Aristóteles teria sido levado a esta síntese, de um lado, pela dificuldade de aceitar a noção pitagórica material de número (aquela das pedrinhas de Eurito, que devia considerar demasiadamente simplória), por outro lado, por considerar mais procedente compreender a existência dos números pitagóricos da mesma maneira como os platônicos tratavam dela,

${ }^{20} \mathrm{Cf}$. o que foi dito acima em relação ao atomismo numérico como modelo fundamental do sistema científico pitagórico para Cornford (1.5).

${ }^{21} \mathrm{C}$. também o que foi dito sobre esse ponto em 1.5 .

${ }^{22}$ Ainda que não seja o caso de referir aqui todos eles. Para os argumentos contrários à tese de Frank, cf. Cherniss $(1935 ; 388-389)$. Para os argumentos contrários à tese da polêmica zenoniana, cf. Burkert (1972: 285-289).

${ }^{23}$ Orig.: «The notion of arithmos is always very closely connected with the operation of counting. To be an arithmos, something must be such as to be counted - which usually means that it must either have discrete and ordered parts or be a discrete part of a larger whole. To give the arithmos of something in the world is to answer the question show manyrabout it. And when the Greek answers «two or sthree here does not think of himself as introducing an extra entity, but as dividing or measuring the entities already in question.»

${ }^{24}$ Orig.: "Is itself a thing"(Burkert 1972: 265). No mesmo contexto, Burkert anota com razão que não deve ser esquecido que o ỏpı $\theta$ ò aquilo que "conta" no sentido de ser importante, de "valer a pena" ser contado. O termo pode ser assim aproximado ao ỏpxท̀ pré-socrático. 
isto é, considerando os árithmoi como archaí. Porém, com isso, Aristóteles faz deslizar toda a problemática da teoria dos números pitagórica para o âmbito acadêmico. Com efeito, Frank (1923: 255) sugere que a fonte dessa “incompreensão" de Aristóteles seja Espeusipo e, portanto, aquela parte da Academia profundamente ligada às tradições pitagóricas. Espeusipo seria, de fato, citado diretamente por Aristóteles em Metafísica (1085a33), quando menciona aqueles "pelos quais o ponto não é um, mas semelhante ao um", isto é, oîn to hén. O ponto, de fato, joga um papel central no trabalho de Espeusipo, que, além de estudioso de Filolau, declarava abertamente ter baseado neste último seus escritos. Essa afirmação encontra-se no fr. 4 (Lang) de Espeusipo, preservado por Nicômaco como parte do livro do primeiro Sobre os números pitagóricos. $\mathrm{O}$ mesmo fragmento constitui a prova direta da derivação acadêmica da teoria dos princípios dos números. Assim, de fato afirmaria Espeusipo: "quando se considera a geração: o primeiro princípio do qual se gera a grandeza é o um, o segundo a linha, o terceiro a superfície, o quarto o sólido"(44 A13 DK // Fr. 4 Lang). ${ }^{25}$

Começa a delinear-se também, nesse âmbito da teoria dos números, a onipresente mediação acadêmica das doutrinas pitagóricas, que tanta parte teve na discussão sobre a teoria pitagórica da imortalidade da alma no capítulo terceiro. A mesma mediação será reconhecida em diferentes modalidades nas páginas a seguir como uma das teses centrais para a explicação da formação da categoria pitagorismo, também em relação à matemática.

É também contraditória com a primeira tese a terceira, isto é, a ideia da mímesis dos números pelos objetos reais. A bem ver, essa tese é referida por Aristóteles com precisão somente uma vez (Met.987b11), no interior da passagem em que a concepção pitagórica é identificada com aquela platônica da participação. Isso faz Cherniss (1935: 392) e Zhmud (1989: 186) considerarem bastante provável que Aristóteles esteja tentando diminuir de alguma forma a originalidade da ideia de méthexis platônica, apontando ao mesmo tempo para Aristóxeno, cujo antagonismo com Platão é bastante atestado. De fato, um testemunho deste último reproduz a mesma ideia da imitação: Pitágoras "assemelha todas as coisas aos números" (fr. 23, 4 Werli).

Em verdade, o próprio Aristóteles refere-se novamente a algo bastante parecido ao conceito de mímesis em outras passagens em que se refere aos números pitagóricos e utiliza termos ligados ao campo semântico da semelhança:

Dado que justamente nos números, mais que no fogo, na terra e na água, eles achavam que viam muitas semelhanças com as coisas que são e que se geram; por exemplo, consideravam que determinada propriedade dos números era a justiça, outra a alma e o intelecto, outra ainda o momento e tempo oportuno e, em poucas palavras, de modo semelhante para todas as outras coisas (Met. 985b27-32).

25 Cherniss (1935: 391) considera a probabilidade de Aristóteles ter derivado também integralmente de Espeusipo a lista dos contrários de Met. 986a22, ainda que simplesmente como a mais bem acabada lista que estava à sua disposição. Sem negar, portanto, a possibilidade de existirem outras listas que podiam ser originalmente pitagóricas. 
É, portanto, nesse sentido das homoiómata que deve ser compreendida a referência à mímesis. ${ }^{26}$

Também a citação acima das pedrinhas de Eurito, em outra página da Metafísica (Met.1092b8-13), pode ser remetida para o interior desse mesmo campo semântico da semelhança e da imitação. Alexandre de Afrodísia, por sua vez, em seu comentário à Metafísica de Aristóteles, explicita o raciocínio que teria levado à definição da semelhança da justiça com o número quatro:

Partindo do pressuposto de que o caráter específico da justiça seja a proporcionalidade e a igualdade, e percebendo que esta propriedade está presente nos números, por este motivo os pitagóricos diziam que a justiça é o primeiro número quadrado; [...] Este número alguns diziam que fosse o quatro, pois é o primeiro quadrado, e também porque é dividido em partes iguais e é igual ao produto destas (de fato, é duas vezes dois) (In Metaph. 38, 10 Hayduck).

Burkert (1972: 44-45) anota que esse conceito de mímesis deve corresponder, senão na terminologia utilizada por Aristóteles, ao menos em seu sentido, a uma teoria pré-socrática, e não já platônica. A ideia fundamental da magia ou da medicina hipocrática é aquela de uma correspondência "de mão dupla” entre duas entidades (o corpo e o cosmo, a arte e a natureza). No caso específico, simplesmente reafirmaria uma correspondência, uma imitação do cosmo com o número e vice-versa. O mesmo Cornford (1922) considerava essa ideia da imitação muito antiga, por causa exatamente de sua característica mistica, que o comentador aproxima diretamente, por meio da etimologia (mimos = ator), aos cultos dionisíacos e ao fato de os protagonistas dos cultos desempenharem o papel do próprio deus:

A esta altura "semelhança com deus" equivale a uma identificação temporária. Induzida pelos sentidos orgiásticos, pelo êxtase báquico ou pelas festas sacramentais órficas, é o aperitivo da reunião final. No pitagorismo, a concepção é mitigada, apolinizada. O sentido não é mais êxtase, ou sacramento, mas teoria, contemplação intelectual da ordem universal (Cornford 1922: 143). ${ }^{27}$

Contra essas hipóteses, todavia, joga o fato de Aristóteles, a bem ver, não indicar a imitação de prágmata, e sim realidades abstratas como a justiça, o tempo etc. ${ }^{28}$ De toda forma, ainda que se possa conceder que Aristóteles esteja se referindo aqui a uma doutrina do protopitagorismo, de estilo acusmático,

${ }^{26}$ Cf. para esta aproximação Centrone (1996: 107-108).

${ }^{27}$ Orig.: "At that stage 'likeness to God' amounts to temporary identification. Induced by orgiastic means, by Bacchic ecstasy or Orphic sacramental feast, it is a foretaste of the final reunion. In Pythagoreanism the conception is toned down, Apollinized. The means is no longer ecstasy or sacrament, but theoria, intellectual contemplation of the universal order". Concorda com a possibilidade desta origem "mística dos números" também Casertano (2009: 67).

${ }^{28}$ Burnet $(1908,119)$, por outro lado, alerta que não se devem levar a sério essas passagens: "They are mere sports of the analogical fancy". 
é certamente o caso de anotar que, na página sucessiva (Met.987b29), exclui veementemente que os pitagóricos concordem com Platão com o papel de méthexis atribuído aos números por este último. A "precisação" de Aristóteles sugeriria, neste caso, que uma intenção polêmica antiacadêmica devesse ser talvez a mais apropriada para explicar este hapax da referência à mímesis. ${ }^{29}$

É possível concluir que as três versões da doutrina “tudo é número" (aquela da identificação, dos números como princípios e esta última da imitação) aparecem articuladas de maneira imperfeita e, no limite, contraditória, em sua tradição no interior da obra aristotélica.

Todavia, é bastante significativo que Aristóteles não mencione em algum momento que as três diferentes lectiones do "tudo é número" devam pertencer a diferentes grupos ou momentos no interior do pitagorismo. De certa forma, parece ainda considerá-las, senão coerentes entre si, ao menos conciliáveis, e as refere todas, indistintamente, aos "assim chamados pitagóricos". ${ }^{30}$

$\mathrm{O}$ reconhecimento disso levou diversos autores a adotarem soluções conciliatórias para o problema. In primis, o próprio Zeller. Ainda que considerasse que o testemunho de Aristóteles devesse ser tomado com todos os cuidados do caso, sua proximidade histórica com as doutrinas pitagóricas deveria garantir, de certa forma, a procedência da especial articulação destas neste contidas. Assim, para Zeller:

Não há dúvida de que na exposição de Aristóteles devemos procurar antes de tudo e somente sua própria maneira de ver, e não um imediato testemunho da realidade de fato, todavia mesmo neste caso [da teoria numérica] tudo fala a favor de um reconhecimento do fato de que esta sua maneira de ver estivesse fundamentada sobre um direto conhecimento da efetiva conexão das ideias próprias do pitagorismo (Zeller e Mondolfo 1932: 486). ${ }^{31}$

Frank (1923: 77 n.196) e Rey (1933: 116), exatamente para exorcizar a possibilidade de incompatibilidade delas, imaginam a possibilidade de Aristóteles ter compreendido as três versões como derivadas logicamente uma da outra. De maneira especial, Rey elabora uma proposta conciliatória entre a versão dos números serem as coisas e aquela dos números imitarem as coisas: os números seriam as coisas quando se considera sua natureza e imitariam as coisas quando se considerassem suas propriedades (1933: 356ss.). ${ }^{32}$ Mais

${ }^{29}$ Este é também um dos motivos que obriga a descartar a hipótese de Burnet (1908: 355) e Taylor (1911:178s), retomada também por Delatte (1922a: 108ss.), pela qual o pitagorismo seria o inventor da teoria das formas platônicas. Assim, Burnet: "the doctrine of 'forms' (eíde, ideíai) originally took shape in Pythagorean circles, perhaps under Sokratic influence” (1908: 355).

30 Por esses motivos, é improcedente, do ponto de vista metodológico, utilizar exclusivamente Aristóteles para afirmar qualquer coisa sobre uma pretensa concepção matemática no protopitagorismo.

${ }^{31}$ Orig.: "non v'há dubbio che nella esposizione di Aristotele noi dobbiam cercare anzi tutto e soltanto il suo proprio modo di vedere, e non un 'immediata testimonianza sulla realtà di fatto. Tuttavia anche in questo caso tutto parla in favore di un riconoscimento del fatto che questo suo modo di vedere si fondasse su una diretta conoscenza della effettiva connessione d'idee propria del pitagorismo".

32 Para críticas à proposta de Frank e Rey, cf. tanto Cherniss (1935: 386) como Burkert 
elaborada é a argumentação conciliatória de Raven (1948: 43-65), pela qual:

Supor, como muitos comentadores parecem supor, que Aristóteles ficou totalmente confuso sobre isso não somente levaria para a porta dele um grande peso, mas também demoliria, com isso, a base central sobre a qual qualquer reconstrução confiável do pitagorismo deve ser erigida (Raven 1948: 63). ${ }^{33}$

Em aberta polêmica com Cornford (1923: 10) e sua ideia de que Aristóteles estaria aqui apresentando, sem distingui-los, dois momentos do pitagorismo (um primeiro ligado à ideia de uma materialidade dos números, um segundo em que os pitagóricos estariam mais preocupados com a composição numérica da realidade), Raven propõe, ao contrário, uma radical indissociabilidade do uso dual dos números no interior do pitagorismo antigo. ${ }^{34}$ Aristóteles estaria assim simplesmente recebendo deste último uma concepção da natureza como igual aos números, no sentido de constituir uma agregação de unidades espaciais (1948: 62). Contudo, os números não constituiriam somente a matéria da realidade, e sim estariam também à origem das diferenças qualitativas que distinguem uns objetos materiais dos outros. Somente assim seria possível pensar tanto a versão da imitação como aquela dos números dos princípios como articulada com a primeira versão. ${ }^{35}$

É certamente possível ao menos afirmar que a ideia de mímesis atribuída aos pitagóricos por Aristóteles não tem muito a compartilhar com a paralela concepção platônica de mímesis pela qual as realidades fenomênicas imitam, no sentido de serem feitas "à semelhança de", outras realidades suprasensíveis de nível ontológico superior, isto é, as formas. E, se essa observação é correta, o que Aristóteles deve atribuir aos pitagóricos, quando fala da mímesis, não pode ser outra coisa senão uma genérica correspondência entre as coisas e as relações numéricas que as explicam, que as tornam inteligíveis. Resume bem a questão Casertano:

Inteligibilidade imanente, portanto, e não trascendente às coisas mesmas. É por este motivo que as fórmulas pitagóricas "as coisas são números" e "as coisas assemelham-se aos números" não estão em contraste; ao contrário, são expressões de uma mesma intuição fundamental, que é aquela da homogeneidade entre realidade e pensamento, entre as leis da realidade e as leis do pensamento: compreender as coisas é essencialmente espelhá-las, reproduzir em nível mental aquela estrutura, plenamente inteligível, que é própria da realidade material (Casertano 2009: 65). ${ }^{36}$

(1972: 44 n.86).

33 Orig.: "To suppose, as so many scholars appear to suppose, that Aristotle was hopelessly confused about it, is not only to lay a very serious charge at his door, but also, incidentally, to demolish the main basis upon which any reliable reconstruction of Pythagoreanism must be erected".

${ }^{34}$ Cornford afirma de fato que: "Aristotle himself draws attention to the two diverse ways of making numbers 'the causes of substances and being', which, in my view, are characteristic of the two different schools of Pythagoreans"(Cornford 1923: 10).

${ }^{35}$ Sobre a mesma ideia, cf. também Guthrie (1962: 230s).

${ }^{36}$ Orig.: "Intelligibilità immanente, appunto, e non trascendente le cose stesse. Ecco perchè le 
Apesar de estar clara, portanto, aquela que podia ter sido a intuição fundamental dos pitagóricos, isto é, a possibilidade de compreender a natureza pelos números, o fato é que a tentativa de conciliação aristotélica entre as diferentes versões da teoria não pareceu, de toda forma, bem-sucedida.

Se, além do mais, considera-se que a versão principal da doutrina pitagórica, aquela da identidade do número com as realidades, obedece diretamente à intenção polêmica de Aristóteles com o platonismo, levando-o a considerar o árithmos pitagórico como causa material, em oposição à militância platônica em favor da causa formal (Cherniss 1935: 360), torna-se difícil definir indiscutivelmente qual seria o valor historiográfico da doutrina pitagórica do "tudo é número". ${ }^{37}$

\subsubsection{Duas soluções}

A esta questão do valor da afirmação aristotélica "tudo é número" como descrição válida da filosofia pitagórica foram propostas duas soluções.

A primeira parte da contestação radical da validade do testemunho aristotélico, chegando a simplesmente negar que ao protopitagorismo corresponda uma doutrina do número "tout court". Os motivos para essa contestação não faltam e podem ser resumidos, fundamentalmente, no paradoxo de uma doutrina que, ainda que amplamente atestada na principal fonte para o pitagorismo antigo, isto é, Aristóteles, todavia não parece encontrar confirmação nos testemunhos mais antigos. É desse paradoxo que Zhmud (1989), no artigo citado anteriormente, começa sua argumentação. É certamente o caso de segui-la passo a passo.

O horizonte em que se insere a reflexão de Zhmud é aquele de uma história da tradição que define a categoria pitagorismo a partir de uma identificação doutrinária. Nesse sentido, a preocupação fundamental do autor é aquela de contrastar a impressão que o texto aristotélico parece deixar de que a definição de "alguém que fala de números" seria a melhor definição de um pitagórico. Conforme já foi observado acima (2.2), o critério identitário revelaria quanto de circular, quanto de petitio principii, haveria nessa utilização do critério dos números para identificar um pitagórico (Zhmud 1989: 272). De fato, apesar de diversas tentativas a esse respeito, nenhum historiador - afirma Zhmud - teve sucesso na busca de qualquer doutrina sobre os números nas fontes pré-aristotélicas sobre o pitagorismo (Zhmud 1989: 272). Por outro lado, é o

formule pitagoriche 'le cose sono numeri' e 'le cose somigliano ai numeri' non sono in contrasto, ma sono espressioni di una medesima intuizione fondamentale, che è quella dell'omogeneità tra realtà e pensiero, tra leggi della realtà e leggi del pensiero: capire le cose è essenzialmente rispecchiarle, riprodurre a livello mentale quella struttura, pienamente intelligibile, che è propria della realtà materiale".

37 Centrone (1996: 105) anota neste sentido que "l'interesse [di Aristotele] per il pitagorismo, i cui pregi in definitiva consistono solo nell'assenza dei difetti propri della filosofia dei platonici, non è soverchiante, ed è anzi determinado proprio dalle affinitità con le dottrine platoniche". 
caso de remeter novamente ao que se dizia acima (2.2) em relação ao catálogo de Jâmblico, que encerra a Vida Pitagórica (267). Em nenhum momento, o catálogo revela algum critério doutrinário para a inclusão dos 218 nomes de pitagóricos nele contidos: grande parte deles é lá inserida com base em uma imprecisa aderência ao bíos pitagórico. De fato, em relação mais diretamente à questão (aristotélica) dos números como archaí, então, estranharia a presença de um pitagórico como Hipaso, que, conforme os fragmentos que dele nos resultaram, possuía uma concepção material da arché (como fogo, cf. 18 B7 DK) bem distante, portanto, da doxografia aristotélica da Metafísica.

A partir desses argumentos, Zhmud admite somente duas possibilidades de solução da questão: ou a expressão "tudo é número" pertenceria a um antigo e secreto ensinamento do "divino" Pitágoras, do qual todavia não se teria alguma referência nas fontes mais antigas (e que, portanto, deveria ter sido revelado diretamente a Aristóteles); ou esta expressão, assim como a doutrina a ela colegada, não seria de fato de alguma maneira uma doutrina pitagórica ${ }^{38}$ Esta segunda possibilidade corresponde a uma já clássica posição de Burnet, pela qual “o próprio Pitágoras não teria deixado nenhuma doutrina desenvolvida sobre o tema, enquanto os pitagóricos do quinto século [a.C] não se interessaram em acrescentar nada deste tipo à tradição da escola" (1908: 119). ${ }^{39}$

Ainda que não deva maravilhar, depois dos estudos acima mencionados de Cherniss (1.7), que o método "historiográfico" aristotélico tenha a liberdade de operar reformulações e traduções em seus mesmos termos das doutrinas de seus predecessores, é todavia o caso de perguntar-se o que levaria Aristóteles a postular exatamente essa doutrina do "tudo é número", que, na forma atual, não devia ser pitagórica.

$\mathrm{O}$ que foi dito até aqui pode já sugerir um primeiro esboço de resposta a essa pergunta: de certa forma, Aristóteles é confrontado com grande diversidade de fontes pitagóricas, tanto antigas (Hipaso) quanto a ele mais próximas (Ecfanto, Filolau, Arquitas). Contudo, para as finalidades internas à Metafísica de Aristóteles, conforme se viu acima, essa pletora de pitagóricos precisava ser reconduzida a um denominador comum, a uma escola que, de certa forma, coubesse no percurso histórico-teorético que Aristóteles pretendia desenhar em sua doxografia.

Sem essa redução aos mínimos termos teóricos, de fato, seria impossível inserir os pitagóricos no interior do modelo agônico pelo qual Aristóteles descreve a história dos predecessores (Cherniss 1935:

\footnotetext{
${ }^{38}$ Assim comenta Zhmud: "If we do not wish to think that the central dogma of Pythagorean philosophy was secret, then it would be quite reasonable to suppose: either this dogma was not central, or it was not a dogma at all. Only very few of those who write about Pythagorean philosophy arrive at such a paradoxical conclusion" (Zhmud 1989: 275). Sobre a prática do segredo na comunidade pitagórica mais antiga, cf. acima (2.3).

${ }^{39}$ Orig.: "Pythagoras himself left no developed doctrine on the subject, while the Pythagreans of the fifth century did not care to add anything of the sort to the school tradition". Da mesma ideia também Gigon (1945: 142).
} 
349)..$^{40}$ Somente dessa forma, por exemplo, o arché pitagórico encontra seu lugar de antagonista da causa material jônica. Ao mesmo tempo, todavia, exatamente certa imprecisão terminológica das fontes pitagóricas (da qual, como vimos, Aristóteles parece reclamar em Met. 1092b1-13) permite a inserção do número pitagórico como, ao mesmo tempo, precursor da causa formal platônica. Vale pensar se a reclamação de Aristóteles não seja um blefe, pois se o número já não tivesse esta dupla valência, bem, Aristóteles a teria provavelmente inventado, pois ela calça à perfeição no interior de seu modelo doxográfico.

Assim, a postulação de "tudo é número" teria sido a solução de um problema de Aristóteles e, de certa forma, o início de uma longa tradição que, a partir de Zeller (Zeller e Mondolfo 1938: 435), reduziu a categoria pitagorismo aos estreitos limites dessa doutrina metafísica.

É a partir desse impasse hermenêutico deixado pela solução acima, isto é, da invenção aristotélica de uma categoria historiográfica ("os assim chamados pitagóricos") e de um denominador comum doutrinário para esta ("tudo é número"), que toma corpo uma segunda solução ao problema. Essa segunda solução empreende especificamente uma reavaliação das fontes pitagóricas do século $\mathrm{V}$ a.C em busca de possíveis referenciais históricos da expressão "assim chamados pitagóricos" de Aristóteles.

A começar de uma observação importante: a grande quantidade de referências ao pitagorismo e à teoria dos números em Aristóteles revela um fato inquestionável: Aristóteles devia mesmo possuir diversos textos pitagóricos, por assim dizer, na mesa dele. ${ }^{41}$ Algumas passagens de Aristóteles sugerem que a certeza com a qual considera inquestionáveis certas afirmações sobre os pitagóricos dependa exatamente do fato de ele ter acesso a uma suficientemente ampla literatura de autoria deles. É o caso da discussão sobre se os pitagóricos considerassem o mundo gerado ou não. Aristóteles afirma ser impossível duvidar disso: "Se os pitagóricos admitem ou não um processo de geração dos entes eternos, é questão sobre a qual não resta dúvida" (Met. 1091a13). Da mesma forma, demonstra ter absoluta certeza de que os pitagóricos não haviam tratado dos corpos sensíveis: "Não disseram absolutamente nada sobre o fogo, nem sobre a terra, nem sobre os outros corpos" (Met.990a16-17).

Além disso, a tradição informa-nos que Aristóteles dedicou ao menos dois livros aos pitagóricos como tais, sem contar as obras dedicadas especificamente a Pitágoras ou a um o outro pitagórico específico, como teria sido o caso de Arquitas. ${ }^{42} \mathrm{~A}$ resposta à pergunta sobre quais seriam esses "assim chamados pitagóricos" aos quais Aristóteles quer atribuir a doutrina dos números depende, assim, em boa parte da possibilidade de identificação desses livros. Contudo, os únicos livros dos quais temos notícia, pela tradição, são aqueles de Filolau e Arquitas. Como Aristóteles parece tratar deste último à parte, e não debaixo

\footnotetext{
${ }^{40}$ Sobre o modelo historiográfico agônico de Aristóteles, cf. o que foi dito acima (1.7).

${ }^{41}$ Concordam com isso Burkert (1972: 236), Zhmud (1989: 281), Huffman (1993:57) e Centrone (1996:105).

${ }^{42}$ Para ampla discussão dessas obras e todas as referências ao caso, cf. Burkert (1972,29 n.5).
} 
do guarda-chuva dos assim chamados, o mais provável é que sejam exatamente os livros de Filolau os textos pitagóricos que estavam na mesa de Aristóteles.

Este segundo caminho de solução seria representado, portanto, por Filolau.

É o caso de anotar, ainda, antes de mergulhar naquela que foi tradicionalmente definida exatamente como "a questão filolaica", que não deve maravilhar não se ter chegado antes a essa mesma conclusão metodológica, pela qual a solução do problema da atribuição da doutrina "tudo é número" fosse o estudo dos fragmentos de Filolau. Grande parte da tradição, a começar pelo próprio Cherniss (1935: 386), conforme se acenou acima, não pôde seguir nesse sentido, pois, na esteira de Frank (1923), considerava os textos de Filolau espúrios. Somente a partir da "redescoberta" do valor de parte essencial dos fragmentos de Filolau, já com Burkert (1972, 218ss.) e depois com Huffman (1988; 1993), é que foi possível trilhar esse caminho.

A recente reavaliação do valor histórico dos fragmentos de Filolau permite, portanto, novos passos hermenêuticos anteriormente impossíveis. Contudo, responder à pergunta sobre quem seriam os pitagóricos na obra de Aristóteles com Filolau e, portanto, com o pitagorismo do V século a.C, continua carregando sérias dificuldades para a identificação aristotélica dos pitagóricos como aqueles pelos quais "tudo é número"; por um simples motivo: mesmo em Filolau não há referência explícita a essa doutrina do "tudo é número". Chegou o momento de entrar finalmente no labirinto da questão filolaica (pace Boeckh 1819: 3), para avaliar em que medida uma solução dessa questão possa se apresentar também como solução para a atribuição ao pitagorismo antigo de alguma teoria numérica.

\subsubsection{A “solução" filolaica}

A questão da autenticidade dos fragmentos de Filolau, questão-chave para a definição da categoria pitagorismo em geral e da questão da atribuição ao pitagorismo de uma teoria dos números de maneira especial, apresenta as mesmas feituras da outra mais célebre questão, aquela socrática. A chamada "questão filolaica", que surge já com Boeckh (1819), compartilha com a mais célebre "questão socrática" a dificuldade em distinguir o que seria originalmente pré-platônico (no caso específico, pitagórico) e o que seria, ao contrário, uma reelaboração platônica ou acadêmica de doutrinas anteriores ${ }^{43}$ A solução da questão filolaica se dará, como se verá, na gangorra hermenêutica entre a tradição acadêmica de um lado e a lectio aristotélica, distintas entre si por intenção e métodos.

\subsubsection{Um livro ou três livros?}

${ }^{43}$ Cf. para essa discussão Burkert (1972: 92), que afirma que "the true problem of the Pythagorean tradition lies in Platonism, for Platonizing interpretation took place of the historical reality"; da mesma forma, Huffman (1993:23) considera que "what we have is another version of Socratic question, but this time in regard to the Pythagoreans”. Mais uma vez a escolha platônica de não falar em primeira pessoa, escondendo-se por trás de suas personagens, assim como o uso de citar com extrema parcimônia seus predecessores, joga um papel decisivo para o sugir de uma questão como essa. 
O primeiro problema que o comentador encontra para verificar a autentidade dos fragmentos de Filolau é aquele da inconsistência da tradição sobre a produção literária deste último. Apesar de certa concordância de que Filolau teria sido o primeiro a publicar por escrito as doutrinas pitagóricas, conforme o testemunho de Demétrio de Magnésia (D. L. VIII: 84), a tradição apresenta-nos, ao contrário, duas diversas possibilidades: aquela da existência de três livros (o célebre tripartium) e a outra que se refere à existência de somente um livro de Filolau.

No primeiro caso, o testemunho não passa de uma confusão, típica da literatura pseudoepigráfica e, de maneira especial, pitagórica, que remonta a Sátiro, um peripatético do século III a.C. Filolau é citado no interior de uma referência a uma carta de Platão: "Platão escreveu para Dion para que este comprasse dele [Filolau] os livros pitagóricos”(D. L. VIII: 84). A referência aqui é, portanto, às tá biblia pythagoriká que a tradição bem conhece: "Pitágoras escreveu três obras: Sobre a educação, Sobre a politica e Sobre a natureza" (D. L. VIII: 6).

A informação de que se trata de três livros aparece algumas páginas depois, novamente associada à figura de Filolau. Este é considerado de certa forma como o "editor" do tripartitum:

Até o tempo de Filolau não foi possível conhecer nenhuma doutrina pitagórica; este somente publicou aqueles famosos três livros que Platão, por carta, mandou dizer que fossem adquiridos pelo preço de cem minas (D. L. VIII: 15).

A referência à carta remete ainda mais fortemente à pseudoepigrafia da tradição em questão: era bastante comum, na antiguidade, que um texto pseudoepigráfico fosse acompanhado pela correspondência de uma personagem estimada e acima, literalmente, de qualquer suspeita que atestasse sua originalidade (Burkert 1972: 224).

A tradição dos três livros de Filolau, portanto, deve ter derivado erroneamente dessa memória paralela que atribuía ao próprio Pitágoras a autoria de três livros. $\mathrm{E}$ os motivos para isso não faltavam: primeiro entre todos, o fato de a tradição maior ter sempre identificado, contrariamente a D. L. (VIII: 6), que Filolau teria sido o primeiro escritor do pitagorismo.

A partir de Wiersma (1942), portanto, surge um novo consenso, entre os historiadores, de que devia tratar-se de um único livro. ${ }^{44}$ De fato, nas páginas imediatamente sucessivas, o próprio Diógenes Laércio usa significativamente a expressão gégraphe biblion hén:

Escreveu um só livro, que "conforme atesta Hermipo, por sua vez citando outro autor” o filósofo Platão, tendo chegado na Sicília junto a Dionísio, teria comprado dos parentes de Filolau por quarenta minas alexandrinas de prata, e que teria copiado no Timeu (D. L. VIII: 85).

${ }^{44}$ Sendo neste seguido, entre outros, por Maddalena (1954: 169), Philip (1966: 41), Burkert (1972: 225), Huffman (1993: 26), Centrone (1996: 119). 
A tradição de Hermipo parece, para todos os efeitos, mais antiga. Dois detalhes confirmariam isso: primeiramente, o fato de não precisar da atestação de uma carta de Platão; em segundo lugar, porque a intenção dessa tradição é alheia à própria questão da autenticidade dos textos. Hermipo estava de fato mais interessado em atingir Platão com a acusação de plágio de Filolau em seu Timeu do que em vender como originalmente pitagórico o livro de Filolau. Além disso, a tradição desse mesmo plágio é bastante atestada nas fontes antigas. ${ }^{45} \mathrm{Um}$ verso satírico do amargurado (amarulentus) Timon confirma a existência da tradição sobre o plágio:

Tu também, Platão, foste tomado pelo prurido do saber

$\mathrm{E}$ deste muito dinheito em troca de um pequeno livreto

$\mathrm{E}$ escolhendo a parte melhor, aprendeste a escrever o Timeu (44 A8 DK // Gell. III 17, 6). ${ }^{46}$

A acusação contra Platão, de toda forma, e com testemunhos externos como aquele de Timon agora citado, pressupõe a existência, senão do plágio, ao menos do livro de Filolau. E, ainda que não tenha sido comprado pelo próprio Platão, este livro devia estar de alguma forma em Atenas, à disposição tanto de Platão quanto de Aristóteles. ${ }^{47}$

Há até uma confirmação documental disso, que vem da descoberta, em 1893, do papiro catalogado como Anônimo Londinense (44 A27-28 DK). O texto é atribuído ao discípulo de Aristóteles, Mênon, e apresenta extratos de doutrinas médicas atribuídas a Filolau.

Filolau de Crotona afirma que nosso corpo é constituído de calor. Que este não participe do frio induz-se de certos fatos como os seguintes: o esperma, que possui a propriedade de produzir o ser vivente, é quente. [...] O desejo do ar externo nasce exatamente dessa necessidade, que o nosso corpo, sendo demasiadamente quente, inspirando-o se esfrie ao contato com este. [...] As doenças são geradas ou pela bílis ou pelo sangue ou pelo catarro; estas são as causas do surgimento das doenças (44 A27 DK).

A descrição detalhada do pensamento médico de Filolau, que as passagens do papiro aqui citadas reproduzem, pressupõe evidentemente uma fonte escrita

${ }^{45}$ Pela verdade, a tradição dos plágios de Platão é realmente bastante extensa. Cf. para isso a longa seção dedicada às acusações de plágios em D. L. III: 9-18. Para recente discussão da questão, cf. Brisson (2000b: 35-45).

${ }^{46} \mathrm{~A}$ mesma tradição é lembrada por Jâmblico em sua Introdução à aritmética de Nicômaco (105), que menciona o livro como sendo de autoria de Timeu de Locros. Para recente edição crítica do livro, cf. Timaeus Locros (ed. Marg, 1972).

${ }^{47}$ Huffman (1993: 30) sugere, para defender a autenticidade do livreto das possíveis suspeitas de ele próprio ser um falso acadêmico, que a referência de Timon à pequenez do livro de Filolau indicaria com maior razão uma origem pré-socrática deste, pois os livros dos pré-socráticos seriam todos de fato de reduzidas dimensões. A sugestão não convence totalmente, pois não é evidente o que deva ser compreendido como um livro de pequenas dimensões no IV século a.C. 
por trás deste. ${ }^{48} \mathrm{E}$, certamente, é o caso de notar que a terminologia médica não está ausente do Timeu de Platão (Burkert 1972: 227). Dessa forma, a prova material que o papiro representa pode ainda ser aproximada à tradição da acusação do plágio platônico, tornando-a com isso ainda mais confiável.

\subsubsection{Autenticidade dos fragmentos de Filolau}

Ainda que esteja razoavelmente comprovada a probabilidade da existência de um só livro de Filolau, contudo a questão filolaica está longe de ser resolvida. Esta sofre dos mesmos problemas historiográficos que acompanham a questão das fontes de toda a literatura pitagórica antiga. Acontece algo contrário ao que ocorre normalmente na crítica da tradição: parte-se em geral do pressuposto de que tudo esteja falso e o ônus da prova fica por conta de quem deseja defender a autenticidade de um ou outro texto. ${ }^{49}$

De fato, diversos comentadores anotam ceticamente (e com uma ponta de cinismo metodológico) que a existência de um único livro seria mais um motivo para considerar todos os fragmentos de Filolau como espúrios. A argumentação chega a ser simplória: se somente um livro de Filolau existiu, por consequência, todos os fragmentos a ele atribuídos deverão pertencer a esse mesmo livro. O pressuposto metodológico dessa argumentação encontra refúgio na observação inaugural de Boeckh (1819: 38) pela qual "não resta outra solução senão aquela de reconhecer que tudo o que temos [de Filolau] é genuíno ou de rejeitar tudo como espúrio". ${ }^{50}$ Ainda que Boeckh seja aqui utilizado para rejeitar tudo como espúrio, ao contrário da solução proposta por ele mesmo.

A consequência deste aut-auté desastrosa: uma série de comentadores saiu em busca de três ou quatro passagens evidentemente espúrias, no interior das cerca de 15 páginas da coleção dielsiana dos fragmentos filolaicos, para como se diria em bom português “jogar fora a criança com a água suja”. É certamente o caso de Bywater (1868: 52) e de Burnet (1908: 283) que, ao tratarem da impossibilidade do fr. 12 ser autêntico, tentam mostrar sua continuidade linguística e temática com os outros fragmentos, com a intenção de demonstrar a contaminação de todos. O fragmento em questão (44 B12 DK) refere-se de fato aos "cinco sólidos regulares", que teriam sido, porém, uma "descoberta" somente acadêmica (cf. Resp. VII, 528b). E, todavia, esta única observação não autoriza Burnet a concluir que seja "justificação suficiente para tratarmos os fragmentos de Filolau' como algo bastante suspeito" (1908: 329). ${ }^{51}$

A argumentação desses comentadores não procede fundamentalmente porque parece esquecer estrategicamente que depois do livro de Filolau há um

${ }^{48}$ São desta ideia diversos comentadores, desde Wilamowitz (1920: II 88) até Huffman (1993: 30) e Centrone (1996: 120).

${ }^{49}$ Cf. Burkert (1972: 218) e Huffman (1993: 18).

${ }^{50}$ Orig.: "So bleibt nichts übrig als alles Vorhandene zusammen als ächt anzuerkennen oder als unächt zu verwerfen".

${ }^{51}$ Orig.: "This sufficiently justifies us in regarding the 'fragments of Philolaos' with something more than suspicion”. 
enorme esforço de falsificação de toda a tradição pitagórica que corresponde ao período pseudoepigráfico: a coleção de Thesleff (1965) conta com cerca de duzentas páginas desses textos. Diante, portanto, dessa luxuriosa tradição pseudoepigráfica - o termo é de Huffman (1993: 27) -, seria estranho que Filolau tivesse ficado imune a ela. ${ }^{52}$

Há, portanto, sérios motivos para enfrentar atentamente a questão da produção literária pseudoepigráfica que marca sensivelmente as fontes pitagóricas mais antigas. Ainda que Burkert não esteja totalmente desprovido de razão quando afirma que, no caso de Filolau, o trabalho pseudoepigráfico não fazia muito sentido, pois se tratava de uma personagem muito pouco conhecida, de fato não seria lectio facilior imaginar que a platonização acadêmica da literatura pitagórica antiga, que marca a pseudoepigrafia de época helenística, tenha poupado somente Filolau. É certamente o caso de concordar com Burkert (1972: 228-229) que as informações que possuímos sobre Filolau não estão associadas normalmente a um corpo de lendas ou anedotas (como é o caso do próprio Pitágoras e de outros pitagóricos), e sim a uma doxografia mais comum entre os pré-socráticos, que é aquela do modelo mestre-discípulo: o nome dele está frequentemente associado àquele de Eurito e Arquitas, sendo os três discípulos imediatos de Pitágoras, como é o caso do já citado catálogo de Jâmblico (Iambl. VP: 267). Filolau é dito também ter sido mestre de Demócrito (D. L. Vitae IX: 38). As formas dessa tradição, portanto, permitem ao menos concluir que uma apropriação pseudoepigráfica tardia do livro de Filolau como um todo não seria a lectio mais provável. Ainda que não se exclua a eventualidade de achar seus sinais.

Consequência das observações acima é, portanto, que a única possível solução da questão filolaica é aquela que obriga a um cuidadoso trabalho de peneira de cada um dos fragmentos em busca de comprovar, caso a caso, sua autenticidade ou menos.

Contudo, antes de empreender essa avaliação mais fina, é certamente o caso de perguntar-se sobre os motivos e as modalidades das falsificações pseudoepigráficas helenísticas, pois estas jogarão um papel essencial no processo de avaliação dos fragmentos de Filolau que se seguirá imediatamente a esta discussão.

\subsubsection{A tradição pseudoepigráfica dórica}

Graças ao enorme trabalho de coleção dessas tradições por obra de Thesleff (1965), é hoje possível ter uma ideia mais precisa dos processos de formação desse variado corpus de obras atribuídas falsamente a Pitágoras e a outros pitagóricos. A economia destas páginas não permite obviamente

${ }^{52}$ Huffman (1993: 27) anota significativamente que o caso de Arquitas é paradigmático, neste sentido: "there are forty-six pages of spourius fragments of Arquitas in Thesleff's collection (1965, 2-48) in comparision with eight short pages of fragments likely to be authentic in DK". O número de textos pseudoepigráficos referidos aos pitagóricos é imensamente superior àquele do conjunto de textos pseudoepigráficos atribuídos a outros pré-socráticos. É este mais um sinal da expansão da tradição, de zelleriana memória, acima mencionada (1.1). 
adentrar em uma questão tão complexa como aquela da formação da tradição pseudoepigráfica pitagórica como um todo. É o caso de remeter, para isso, de um lado, aos estudos ainda insuperados do já citado Thesleff (1961; 1965), do outro, ao percurso historiográfico desses estudos, que chega até o neoplatonismo, magistralmente descrito por O'Meara (1989).

Contudo, é necessário ao menos anotar duas características dessas "falsificações", ambas centrais para a avaliação dos fragmentos de Filolau.

A primeira é aquela do uso do dialeto dórico que acomuna praticamente toda a coleção. Thesleff cunha, para isso, a expressão "dórico pitagórico", pois o uso desse dialeto arcaico "reflete uma específica maneira de escrever prosa que é realmente tentador fazer derivar em última análise de Arquitas" (Thesleff 1961: 92). ${ }^{53} \mathrm{Se}$ o uso artificial do dórico, como arcaísmo linguístico, desempenha papel fundamental na estratégia de falsificação, as tentativas críticas de desvendá-la se utilizarão da mesma estratégia, portanto, ainda que em sentido contrário. Uma questão sensível para a argumentação destas páginas é que também os fragmentos de Filolau foram escritos em dórico. Todavia, esse não pode ser motivo para considerá-los per se pseudoepigráficos, pois até o fim do $V$ século a.C o dórico é um dialeto ainda amplamente utilizado. Prova disso é que o utilizam tanto Arquitas quanto o médico Acron de Acragas, assim como os oradores Tísias e Córax. ${ }^{54}$

A segunda característica desse corpus, talvez a mais importante, é a presença, nos textos pseudoepigráficos, de conceitos que dependem diretamente das filosofias de Platão e Aristóteles. De fato, as fontes acadêmicas, desde o começo, revelam clara tendência em identificar grande parte das doutrinas platônicas como originárias de Pitágoras (Burkert 1972: 92-93). Heidel (1940, 7), em sua história da matemática grega, revela ser quase impossível verificar o que seja pitagórico e o que seja platônico nas fontes antigas sobre a matemática..$^{55}$ Também Aristóteles afirma que a filosofia de Platão segue em muitos pontos aquela dos pitagóricos e apresenta-se basicamente como uma síntese entre Sócrates e Pitágoras (Met. 987a29). ${ }^{56}$

Não por acaso, a Vida de Pitágoras que Fócio reproduz em sua Biblioteca, revelando uma intenção genealógica também típica do platonismo tardío,

${ }^{53}$ Orig.: "It reflects a specific manner of writing prose which it is very tempting indeed to derive ultimately from Arquitas".

${ }^{54}$ Cf. para as referências Burkert (1972: 222). Burnet (1908: 327), por sua vez, considerava impossível que Filolau tivesse escrito em dórico: "Is it likely that Philolaos should have written in Doric? Ionic was the dialect of all science and philosophy till the time of the Peloponnesian War, and there is no reason to suppose that the early Pythagoreans used any other"; apesar de demonstrar conhecer a opinião de Diels, pela qual Filolau e Arquitas teriam sido os primeiros a escrever no dialeto das colônias da Magna Grécia que os acolheram. Huffman (1993: 27 n13), reproduzindo os argumentos de Burkert, considera de fato o argumento de Burnet insuficiente.

${ }^{55}$ Cf. Heidel (1940: 7): "it is difficult if not impossible for the most part to distinguish what is Platonic and what is Pythagorean".

${ }^{56}$ Ainda que Aristóteles se distancie do processo de identificação absoluta entre pitagorismo e platonismo no caso em que, por exemplo, faz derivar a teoria das formas de Crátilo e Sócrates. De fato, como se verá, a platonização do pitagorismo desenvolve-se em sentido contrário a esta lectio aristotélica que está mais interessada em distinguir do que em aproximar. 
coloca Platão como nono sucessor de Pitágoras e Aristóteles, como décimo: "Platão, ele que havia sido discípulo do mais velho Arquitas, tornou-se, conforme dizem, o nono diádoco de Pitágoras, e Aristóteles foi o décimo" (Phot. Bibl. 249.438b16-17). ${ }^{57}$

Todavia, com a guinada cética da Média Academia, encabeçada por Arcesilau, a tradição platônica acaba por identificar-se mais com o lado socrático e Pitágoras torna-se ao mesmo tempo um problema e a solução de outro. ${ }^{58}$ De fato, ao mesmo tempo em que a influência de Pitágoras é negada para definir uma tradição menos dogmática do platonismo, o próprio Pitágoras é utilizado para que seja atribuída a ele aquela parte da doutrina platônica que, por ser demasiadamente metafísica e matemática, não era mais o caso de atribuir ao próprio Platão.

Em contrapartida, a reação ao ceticismo que começa a ser esboçada com a chegada do dogmático Antíoco de Áscalon, que inaugura uma nova mudança de rumo na Academia, inspirou certamente as acusações de plágio contra Platão, entre elas certamente a que se viu anteriormente em relação ao livro de Filolau. Em sentido contrário, portanto, e quiçá mais próximo da visão da primeira Academia de Espeusipo e Xenócrates, os acadêmicos partidários da influência pitagórica sobre Platão acabam por atribuir a todos os representantes da filosofia platônica, incluindo neles obviamente também Sócrates e Aristóteles, uma apropriação fraudulenta da doutrina de Pitágoras. ${ }^{59}$

É esta a polêmica que envolve ainda o neoplatonismo de Numênio de Apaméia, e depois de Porfírio e Jâmblico. Os três, ainda que com intensidades diferentes, declaram querer reestabelecer o verdadeiro Platão, purificando-o de todas as sobreposições doutrinárias de Aristóteles e dos estoicos. ${ }^{60} \mathrm{O}$ título da obra de história da filosofia platônica escrita por Numênio é significativo do clima polêmico da questão: Sobre a discordância entre os acadêmicos e Platão. Sua conclusão é simplesmente que o verdadeiro platonismo é pitagorismo (fr. 24, 73-79), contra o que os "acadêmicos", por ele identificados simplesmente com os céticos, andavam afirmando. ${ }^{61}$ Ecos dessa polêmica aparecem também em Porfírio, que afunda a faca contra a tradição platônica, acusando-a de plágio e de má-fé, por ter estabelecido uma história do pitagorismo diretamente intencionada a ridicularizá-lo:

Os escritos são em dórico e esse dialeto possui algo de pouco claro: exatamente por esse motivo também as doutrinas que este investigava foram suspeitas de serem apócrifas e fruto de desentendimentos, pois não teriam sido pitagóricos

${ }^{57}$ Burkert (1972: 53) anota que a autoria da obra pode ser do próprio Eudoro.

${ }^{58}$ Cf. para isso Dillon (1977), Leszl (1981) e Isnardi Parente (1989). Para recente discussão desta guinada cética da Academia de meio, veja-se o Epílogo do excelente estudo de Dillon sobre a herança platônica (2003: 234ss.).

${ }^{59} \mathrm{Cf}$. também os argumentos nesse sentido de Centrone (2000: 155).

${ }^{60}$ Burkert pode assim concluir que "one might therefore define later Pythagoreanism as Platonism with the Socratic and dialectic element amputated” (Burkert 1972: 96).

${ }^{61}$ Cf. para isso O’Meara (1989: 10-14). 
ortodoxos os que as divulgavam. Além disso, Platão, Aristóteles, Espeusipo, Aristóxeno e Xenócrates, pelo que diziam os pitagóricos, apropriaram-se, com pequenas modificações, das doutrinas frutíferas, enquanto teriam recolhido e compilado como doutrinas específicas da filosofia pitagórica tudo quanto havia de ridículo e supérfluo e tudo aquilo que posteriormente os caluniadores haviam apresentado para refutar e denegrir a escola (Porph. VP: 53).

A passagem reivindica assim uma identidade doutrinária pitagórica em aberta polêmica com a tradição tanto acadêmica quanto peripatética. Os pitagóricos aqui referidos foram identificados com a vertente neopitagórica representada mais especificamente por Moderato de Gades. ${ }^{62}$ A literatura pitagórica pseudoepigráfica helenística, portanto, deverá ser compreendida no interior dessa polêmica intra-acadêmica que se estende até à época imperial. ${ }^{63}$ A presença de diversos conceitos e temáticas que pressupõem, portanto, não somente Platão, mas mesmo Espeusipo ou Teofrasto, não devem maravilhar. ${ }^{64}$

Nessa reconstrução platônico-pitagorizante da filosofia dos "antigos”, a descrição que Aristóteles, no século IV a.C, faz do pitagorismo não encontra eco algum. Ao contrário, a tradição neoplatônica conta diversas acusações contra a lectio de Aristóteles. Siriano e Proclo acusam abertamente Aristóteles de distorção do pensamento dos pitagóricos (Syrian In Met. 80: 22; Procl. In Tim. 1: 16, 29). Especialmente significativo é um texto pseudoepigráfico, atribuído a Teano, esposa e discípula de Pitágoras:

Soube que muitos dos gregos supuseram que Pitágoras teria dito que tudo vem do número. Essa afirmação, contudo, revela uma aporia: como, de fato, algo que nem sequer existe é concebido como genitor. Mas ele não disse que todas as coisas vêm dos números, e sim conforme os números. Pois no número dá-se a primeira ordenação de fato, graças a sua presença, na comunhão das coisas que podem ser contadas, algo toma seu lugar como primeiro, outra coisa como segundo e, em seguida, todos os outros (Thesleff 1965 // Stob. I: 10, 13).

Teano nega assim a doutrina dos números como princípios, atribuindo-a a "muitos dos gregos", ainda que isso signifique fundamentalmente Aristóteles. ${ }^{65} \mathrm{~A}$ escolha de colocar essa negação na boca da própria esposa de Pitágoras obedece a uma bem precisa estratégia, parecida com aquela da falsificação da carta de Platão acima citada, de fornecer autenticidade para aquilo que não a tem.

${ }^{62}$ Concordam com esta atribuição Dillon (1977: 346) e Isnardi Parente (Speusippo 1980: 237-238). Contrários, Burkert (1972: 95) e O’Meara (1989: 11 n8).

${ }^{63}$ Cf. Centrone (2000) para ampla resenha da recepção do pitagorismo no platonismo de época imperial.

${ }^{64}$ Para mais precisa avaliação da influência das tradições acadêmica e peripatética mais antigas sobre a literatura pseudoepigráfica pitagórica - com relativas fontes -, cf. Thesleff (1965), mas também Burkert (1972: 83-96). Huffman (1993: 21) anota com razão que: "even if the forgeries do not arise among the Neoplatonists, the Neoplatonic attitude towards Pythagoras and hence the motive for forgeries could go back much earlier".

${ }^{65} \mathrm{O}$ termo $\gamma \varepsilon v v \tilde{\alpha} v$ poderia ser uma referência direta à página de Aristóteles que fala da

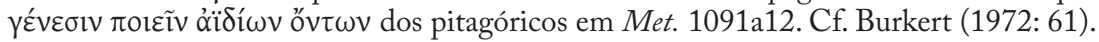


A tematização da diferença da lectio aristotélica em relação ao onipresente "sistema de derivação" da tradição platônica permite voltar novamente à questão filolaica ${ }^{66}$ É exatamente essa diferença a tornar-se uma alavanca hermenêutica para a questão: pois se esta é verdadeira, como se demonstrará, a proximidade dos fragmentos atribuídos a Filolau com a lectio aristotélica dos assim chamados pitagóricos se tornará um sinal inequívoco de sua autenticidade.

É à modalidade dessa distinção que Aristóteles opera entre pitagorismo antigo e recepção platônica e acadêmica deste que se deverá, então, prestar toda a atenção.

\subsubsection{A exceção aristotélica (Met. A 6, 987b)}

Aristóteles, de fato, se por um lado aproxima pitagorismo e platonismo em relação à teoria das formas, por outro lado distingue, sem alguma possibilidade de dúvida, o pitagorismo do platonismo em ao menos duas questões centrais, não somente para a história do platonismo, mas também para a discussão que estas páginas empreendem considerando a concepção pitagórica dos números. As duas questões estão articuladas em célebre página da Metafísica de Aristóteles que, por esse motivo, será preciso analisar antes de dedicar-se finalmente aos fragmentos de Filolau. Trata-se mais precisamente da página $987 \mathrm{~b}$.

O argumento inicia-se com a já amplamente citada questão da discordância dos pitagóricos com Platão a respeito do papel dos números na existência das coisas sensíveis. Aristóteles exclui veementemente que os pitagóricos concordem com o papel de méthexis atribuído aos números por este último. A precisão de Aristóteles de que o conceito de mímesis seria o mais adequado para representar a doutrina pitagórica introduz uma mais precisa articulação das diferenças entre pitagóricos e Platão que leva às duas questões centrais: a primeira delas diz respeito ao lugar ontológico dos números; a segunda, à concepção do um.

Assim inicia a página em questão:

Depois das filosofias mencionadas, surgiu a doutrina de Platão, que, em muitos pontos, segue a dos pitagóricos, mas apresenta também características próprias, estranhas à filosofia dos itálicos (Met. 987a29-31). ${ }^{67}$

Aristóteles inicia reconhecendo mais uma vez a analogia entre o procedimento platônico da redução aos princípios e o procedimento pitagórico da redução da realidade aos números. Ainda que, como visto anteriormente, mudem os termos para a descrição dessa relação entre as formas/números e

${ }^{66}$ A expressão é de Gomperz (apud Burkert 1972: 17).

${ }^{67}$ Para diferente interpretação da passagem, que tende a diminuir a lectio aristotélica da influência dos pitagóricos sobre Platão, cf. Huffman (2008: 223). O argumento do autor está

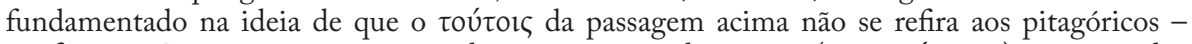
conforme a lectio maior -, e sim a todos os outros predecessores ( $\tau \tilde{\omega} v \pi \rho o ́ \tau \varepsilon \rho o v)$ mencionados nas linhas imediatamente anteriores (Met.987a28). 
os entes sensíveis - mimesis para os pitagóricos, methéxis para Platão (Met. 987b11-12) -, a analogia continua procedente no interior da doxografia aristotélica. De fato, se os pitagóricos são ditos "acreditarem que os princípios [das matemáticas] sejam os princípios de todos os seres" (Met. 985b25), analogamente a Platão é atribuído um processo de redução das formas, que são causas da realidade material, a ulteriores princípios. Aristóteles chama estes de elementos de stoicheía. Os elementos seriam assim, na linguagem aristotélica, causas daquilo que existe:

De fato, dado que as formas são causas de outras coisas, Platão considerou os elementos constitutivos das formas como os elementos de todos os seres. Como elemento material das formas, ele punha o grande e o pequeno, e como causa formal o Um: de fato, considerava que as formas e os números derivassem por participação do grande e do pequeno no Um (Met. 987b18-22).

A página em questão gerou muita polêmica entre os comentadores. A doutrina dos princípios aqui atribuída a Platão não parece encontrar eco imediato nas páginas escritas de seus diálogos. Isso levou uma já consolidada tradição hermenêutica a considerar a possibilidade da existência de ágrapha dógmata, de ensinamentos orais esotéricos de Platão, dos quais essa página aristotélica seria certamente um dos testemunhos mais relevantes. ${ }^{68}$

O que interessa aqui, todavia, é mais simplesmente anotar que Aristóteles, nos termos de sua própria filosofia (aitíai, stoicheia), está comparando pitagóricos e Platão, e achando profundas analogias em seus sistemas ontológicos. Nas linhas imediatamente sucessivas, a analogia é assim resumida:

Quanto à afirmação de que o Um é substância e não algo diferente daquilo a que se predica, Platão aproxima-se muito dos pitagóricos e, como os pitagóricos, considera os números como causa da substância das outras coisas (Met. 987b22-25).

À afirmação dessa analogia, todavia, conforme foi acenado acima, segue, no texto aristotélico, a observação de uma profunda diferença entre as duas doutrinas.

Entretanto é peculiar a Platão o fato de ter posto, no lugar do ilimitado entendido como Um, uma díade, e o fato de ter concebido o ilimitado como derivado do grande e do pequeno. Platão, além disso, situa os números fora dos sensíveis, enquanto os pitagóricos sustentam que os números são as próprias coisas e não afirmam os entes matemáticos como intermediários entre aqueles e estas. $\mathrm{O}$ fato de ter posto o Um e os números fora das coisas, à diferença dos pitagóricos, e também o ter introduzido as formas foram as consequências

${ }^{68}$ Não é certamente possível e oportuno adentrar aqui nesta vexata quaestio que tanta polêmica suscitou nos últimos anos. A posição esotérica é defendida pela assim chamada Escola de Tübingen-Milão. Cf., para isso, Krämer (1959), Gaiser (1963), Szlezák (1985), Reale (1991). Do outro lado, com posições céticas em graus diferentes, Cherniss (1945), Vlastos (1963) e Isnardi Parente (1977). Para resenha mais recente desta questão, cf. Trabattoni (1999 e 2005). 
da investigação fundada nas puras noções, que é própria de Platão, pois os predecessores não conheciam a dialética (Met.987b25-33).

A visão platônica da teoria dos princípios afasta-se da tradição pitagórica, portanto: em primeiro lugar, pelo "fato de ter posto, no lugar do ilimitado entendido como unidade, uma díade, e o fato de ter concebido o ilimitado como derivado do grande e do pequeno"; em segundo lugar, pelo fato de Platão "situar os números (arithmoi) fora dos sensíveis (pará tá aisthetâ), enquanto aqueles [os pitagóricos] sustentam que os números são autá tá prágmata e não afirmam que os matematiká são intermediários (metaxý) entre estes e aqueles". Esta última diferença está baseada fundamentalmente naquele que Aristóteles considera um erro tipicamente platônico (Kahn 2001: 63). Trata-se da doutrina do chorismós, isto é, da separação das formas/números do mundo sensível, que Aristóteles considera ter surgido já com a dialética socrática, estando assim ausente da filosofia dos pitagóricos. ${ }^{69}$

Não é o caso de aprofundar ainda mais esta diferença. Será suficiente lembrar mais uma vez que essa reconstrução doxográfica da ideia da identidade do número com a realidade, conforme foi visto acima (4.1.1), obedece claramente à intenção polêmica de Aristóteles com o platonismo. Esta se encontra expressa de forma tão definitiva nas categorias de sua própria filosofia, ao ponto de tornar impossível, em última análise, resgatar um eventual sentido originário da doutrina pitagórica do "tudo é número". Todavia, não se trataria aqui de deformação das doutrinas pitagóricas originárias, e sim, mais propriamente, de uma tradução destas em outros termos. Prova disso seria a própria intenção de Aristóteles de desenhar a diferença entre pitagorismo e Platão, que, portanto, lhe impediria de incluir apropriações totalmente arbitrárias, ou até mesmo forjadas, das doutrinas dos dois lados, sob pena de perder desta forma seu argumento (Centrone 1996: 109). ${ }^{70}$ Por outro lado, as duras críticas a essa lectio aristotélica por autores acadêmicos como Siriano e Proclo e pela tradição pseudoepigráfica platonizante que está por trás do texto de Teano, confirmariam tratar-se aqui de uma tradição externa à tradição platônica. Todos esses argumentos permitem imaginar tratar-se, no caso da identificação dos números com a realidade, ainda que nos termos da tradução aristotélica, de um achado da visão pré-socrática dos números pitagóricos. ${ }^{71}$

Uma segunda diferença entre Platão e pitagóricos está na maneira como é

${ }^{69}$ Cf. para isso mais recentemente também Szlezák (2011): “certamente podemos acreditar em Aristóteles quando diz que o chorismós, tão característico da teoria platônica das idéias, pertence, também no caso da filosofia do número, apenas a Platão e à Ácademia, e não aos pitagóricos" (2011,126).

${ }^{70}$ Da mesma ideia Isnardi Parente (1977: 1034), que afirma: "naturalmente il giudizio aristotelico, come di consueto, implica una sovrapposizione delle proprie categorie interpretative a quelle del pensatore della critica, ma contiene anche un nucleo di attendibilità da non trascurarsi”.

${ }^{71}$ Comenta entusiasticamente Burkert (1972: 32): "is treasure-trove for the historian: herewe have a piece of Pythagorean doctrine that was not subsumed into Platonism”. 
concebido o um, ou, mais precisamente, no "fato de [Platão] ter posto, no lugar do ilimitado entendido como unidade, uma díade, e o fato de ter concebido o ilimitado como derivado do grande e do pequeno". A crítica de Aristóteles não pode ser menos contundente:

Contudo, o ter posto uma díade como natureza oposta ao Um tinha em vista derivar facilmente dela, como de uma matriz, todos os números, exceto os primeiros. Entretanto, ocorreu exatamente o contrário, pois esta doutrina não é razoável (Met.987b33-988a2).

O fato de colocar uma díade no lugar do hén ápeiron, do um ilimitado pitagórico (com a intenção de derivar dela mais facilmente todos os outros números), acaba resultando em uma doutrina "ou eulógos", isto é, em uma teoria que não procede do ponto de vista argumentativo.

Aristóteles, mais uma vez, está sozinho na definição dessa diferença. A tradição doxográfica toda sublinha, ao contrário, que também os pitagóricos postulavam o um e a díade indefinida como princípios da realidade. É certamente o caso de um célebre fragmento de Espeusipo, citado por Guilherme de Moerbeke em sua tradução latina do comentário de Proclo ao Parmênides de Platão. Proclo refere-se à opinião dos antigos (tamquam placentia antiquis) pela qual:

Eles, considerando que o um é superior ao ser e de tal forma que deste deriva o ser, tornaram-no livre da condição de princípio. Por outro lado, considerando que com o um concebido, em si mesmo, enquanto separado e sozinho, sem as outras coisas, sem algum outro elemento adicional, nada mais viria a existir, por isso introduziram a dualidade infinita como princípio dos seres (Speusip. fr. 48 Tarán). ${ }^{72}$

A referência aos antiqui não poderá ser compreendida, certamente, como uma remissão a Platão, que é praticamente coetâneo. Por exclusão, os antigos serão, então, os pitagóricos. Estes são chamados de palaioi por Platão, em uma passagem do Filebo que será analisada em breve (Phlb. 16c). ${ }^{73}$

Prova da força dessa tradição acadêmica é que até Teofrasto, discípulo imediato de Aristóteles, é influenciado por ela a tal ponto de considerá-la também verdadeira e, portanto, afastar-se da lectio que havia recebido de seu mestre:

${ }^{72}$ Orig.: "le unum enim melius ente putantes et a quo le ens, et ab ea quae secundum principium habitudine ipsum liberaverunt, exstimantes autem quod, si quis le unum ipsum seorsum et solum meditatum sine aliis seCtmdum se ipsum ponat, nullurn alterum elementum ipsi apponens, nihil utique flet aliorum, interminabilem dualitatem entium principium induxerunt" (Speusip. fr. 48 Tarán).

${ }^{73}$ Concordam com esta atribuição Burkert (1972: 63), Huffman (1993: 23), Centrone (1996: 110) e Kahn (2001: 64). Contrário a esta atribuição, o próprio Tarán (Speusippus 1981: 350s), que atribui a referência aos antigos a Proclo e não a sua fonte Espeusipo, dessa forma invertendo a atribuição da passagem para os acadêmicos. 
Platão e os pitagóricos tornam grande a distância [entre o real e as coisas da natureza], mas consideram que todas aquelas coisas desejam imitar o real. E a partir do momento em que definem uma espécie de oposição entre o um e a díade indefinida, da qual em última análise depende o que é ilimitado e desordenado e, para assim dizer, toda a dismorfia, é absolutamente inconcebível que para eles a natureza do todo existisse sem esta [díade indefinida] (Theophr. Met.11a27-11b6).

Não somente Platão e os pitagóricos são aproximados por separarem o real (ontológico) das coisas da natureza, mas também por compreenderem que, sem a aoristós dýas, o mundo não poderia ser gerado. Nessa perspectiva, ao lado do um, a postulação da díade indefinida como um dos princípios é absolutamente necessária. Estamos já em pleno solo acadêmico, portanto.

Contudo, a citada passagem da outra Metafísica, aquela de Aristóteles, não deixa dúvidas que essa diferença devia mesmo existir. A té porque não se trata de um hapax legomena, e sim - conforme se verificou acima (4.1.1) - de uma peça de um quebra-cabeça maior, que contribuiu para a definição de uma concepção pitagórica dos princípios que Aristóteles considerava a tal ponto coerente que não tentou atribuí-la a momentos ou protagonistas diferentes da história do pitagorismo. Pouco antes, de fato, Aristóteles atribui aos pitagóricos - em continuidade com outros itálicos (Empédocles e Parmênides) e Anaxágoras uma teoria dos dois princípios:

Os pitagóricos afirmaram do mesmo modo dois princípios, mas acrescentaram as seguintes peculiaridades: consideraram que o limitado, o ilimitado e o um não eram atributos de outras realidades (por exemplo, fogo ou terra ou alguma outra coisa), mas que o próprio ilimitado e o um eram substância das coisas das quais se predicam, e que por isso o número era a substância de todas as coisas (Met. 987a13-19).

Aqui, os dois princípios pitagóricos são ditos peperasménon e apeiron, isto é, limitado e ilimitado. Todavia, Aristóteles com a expressão kai tó hén acrescenta um terceiro princípio, o um. Como compreender que Aristóteles anuncia aqui dois princípios e acaba depois identificando três: "limitado, ilimitado e um"? $\mathrm{O}$ reconhecimento dessa contradição no testemunho de Aristóteles faz alguns autores excluírem a expressão kai tó hén da passagem. ${ }^{74}$ Com essa exclusão, o um acabaria assim por ser identificado com o limitado. De fato, na segunda menção que a passagem faz aos dois princípios, a referência ao limitado não é repetida e os dois princípios são identificados como ilimitado e um, com este último tomando o lugar - por assim dizer - do limitado.

Exatamente pelo fato de que para um platônico essa equação hén-péras

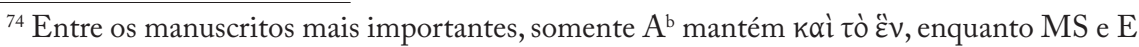
excluem (e com eles Ross, cf. acima).Burkert (1972:36 n38) lembra que Alexandre de Afrodísia, em seu comentário (In Met. 47,11), lê a expressão kai tó hén: coisa não óbvia, por se tratar de

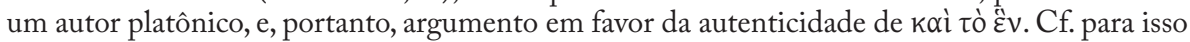
Burkert (1972: 35-37), Centrone (1996: 111) e Huffman (1993: 206).
} 
devia ser algo absolutamente normal, Huffman (1993: 207) sugere que Aristóteles esteja aqui cometendo um deslize (slide), de maneira especial se esta passagem for comparada com a passagem de Met. 987b25-33. Aristóteles procurava ali mostrar a analogia dos dois princípios platônicos (um e díade indefinida) como os princípios pitagóricos do limitado e ilimitado. Porém, apesar de reconhecer que há uma diferença entre as duas filosofias, pois Platão considera o ilimitado como uma dualidade (grandepequeno) e os pitagóricos não, Aristóteles não tematiza claramente alguma diferença entre os outros dos princípios comparados: isto é, o um platônico e o peperasménon pitagórico. Essa falta de tematização explicaria a dupla versão que aparece na passagem relativa aos dois princípios que estamos examinando: na segunda parte dela (v.18), Aristóteles estaria, consciente ou inconscientemente, caindo na falácia da interpretação platonizante que identifica o um com o limitado; enquanto na primeira parte dela (v.16), Aristóteles acrescentaria o um como algo distinto dos dois princípios: limitado e ilimitado. ${ }^{75}$

Apesar do possível deslize platonizante, portanto, que mostra a força do "sistema de derivação" platônico acima citado, é ainda a primeira afirmação a estar em acordo com toda a lectio aristotélica dos números enquanto eles próprios criados a partir dos princípios. Conforme se verá na comparação com Filolau, essa interpretação deverá corresponder mais precisamente ao pensamento dos pitagóricos.

A confirmação disso, a ideia pela qual o número seja composto por ambos os princípios, limitado e ilimitado, aparece claramente em uma passagem imediatamente anterior, pela qual os pitagóricos:

Afirmam como elementos constitutivos do número o par e o ímpar; dos quais o primeiro é ilimitado e o segundo limitado. O Um deriva de ambos os elementos, porque é par e ímpar ao mesmo tempo. Do Um procede depois o número; e os números, como dissemos, constituiriam a totalidade do universo (Met. 986a 17-21).

Essa derivação faz sim que o um seja ao mesmo tempo par e ímpar e, como tal, princípio dos números. Aqui, os dois princípios são o par e o ímpar, enquanto limitado e ilimitado parecem ser somente atributos destes. Aristóteles explica essa correspondência entre par e limitado de um lado, e ímpar e ilimitado do outro, em uma difícil passagem da Física (203a). A mesma ideia reaparece também em seu fr. 199 (Rose), provavelmente extraído de um de seus livros sobre os pitagóricos, e encontra um eco significativo na ideia do artiopéritton, o "parímpar", do fr. 5 de Filolau. Será o caso de voltar em breve para ela, portanto.

A diferença mais significativa que Aristóteles consegue perceber entre

${ }^{75}$ A possibilidade de um deslize inconsciente de Aristóteles é um argumento que, a bem ver, requereria metodologicamente verificações de fato impossíveis. E, todavia, é sugerida tanto por Burkert (1972: 36) quanto por Huffman (1993: 206). 
os pitagóricos e Platão está, todavia, ainda conectada à ideia do chorismós, conforme aparece na passagem central de Met.987b25-33 e que o faz concluir que, para os pitagóricos, os números são as próprias coisas. Essa afirmação possui imediatamente uma valência cosmológica, obviamente. De fato, em relação às duas questões que estamos analisando, isto é, tanto aquela da identidade entre os números e a realidade como a da geração dos números a partir dos princípios limitado e ilimitado, Aristóteles empreende uma descrição em termos cosmológicos (Burkert 1972: 31ss.). Isso aparece de forma mais evidente na passagem da Física em que se trata do vazio:

Também os pitagóricos afirmaram a existência do vazio, e que entra no céu pelo sopro ilimitado, como se o céu respirasse, e que o vazio delimita a natureza das coisas, como se o vazio fosse alguma coisa de separado e delimitasse as coisas consecutivas. E isso acontece primeiramente nos números, pois o vazio delimita sua natureza (Phys. 313b23-27).

Aqui, o ilimitado não é somente um princípio ontológico separado da realidade, como o seria a díade infinita platônica, e sim algo que é "inspirado pelo céu" para dar origem à multiplicidade dos seres. Uma página da Metafísica espelha a mesma visão ontológica:

De fato, eles afirmam claramente que, uma vez constituído o Um - seja com planos, com cores, com sementes, com elementos dificilmente definíveis -, imediatamente, a parte do ilimitado que lhe era mais próxima começou a ser atraída e delimitada pelo limite (Met.1091a15-18).

Timpanaro Cardini (1958-62, III: 154) anota que pode tratar-se aqui de um achado aristotélico de diversas doutrinas que eram desenvolvidas pelo pitagorismo antigo para explicar como era formado o um. O plano corresponderia a uma primeira hipótese, geométrica; a chroiá, a cor, corresponderia à superfície do corpo, isto é, a seu péras, ainda que não identificável com corpo mesmo. ${ }^{76}$ Uma terceira hipótese, que postulava o spérma, é de fato facilmente reconduzível ao já citado fr. 13 de Filolau (44 B13 DK) e à afirmação pela qual "todas as coisas brotam e crescem por causa da semente".

A geração do cosmo é assim descrita como o nascimento de um organismo vivente, isto é, utilizando um léxico embriológico, que apresenta analogias com aquele das antigas teorias embriológicas: a geração do embrião, de fato, se daria nelas por meio da respiração. ${ }^{77} \mathrm{O}$ léxico embriológico e o pressuposto da correspondência macrocosmo-microcosmo remetem para uma origem mais antiga, com toda probabilidade pré-socrática, dessa doutrina. ${ }^{78}$

${ }^{76}$ Cf. para isso o próprio Aristóteles (De sensu 439a30).

${ }^{77}$ Cf. para as citações, Burkert (1972: 37), Huffman (1993: 289-306) e Centrone (1996: 115).

${ }^{78}$ Burkert (1972:39) vai além e, em consonância com sua apresentação do pitagorismo entre lore e science, atribui esta mistura de teoria numérica e cosmogonia a uma direta influência órfica: "Orphism and Pythagoreanism were almost inextricably intertwined in the fifth century, so that it is understandable that, within the pre-Socratic domain, Pythagorean doctrine developed 
$\mathrm{E}$, todavia, dessa indiferenciação entre o plano numérico e aquele cosmológico na doutrina dos "assim chamados pitagóricos", Aristóteles reclama, com se viu, afirmando que a postulação desses princípios não explica nem o movimento nem o peso dos corpos (Met.990a7-13). O motivo dessas aporias é um só: "os princípios que [os pitagóricos] postulam e fazem valer referemse tanto aos corpos matemáticos quanto aos corpos sensíveis" (Met. 990a1416). Identificando os princípios com o mundo sensível, de fato, os pitagóricos perderiam o sentido heurístico desses princípios. Pergunta-se, de fato, Aristóteles:

Como se deve entender que as propriedades do número e o número são causas das coisas existentes no universo e das coisas que nele se produzem desde a origem até agora e, de outro lado, como entender que não existe outro número além do número do qual é constituído o mundo? (Met.990a18-22).

Obviamente, não há possibilidade de resposta para essas perguntas. Pois a indiferenciação entre o plano numérico e aquele cosmológico impediu que o problema pudesse ser solucionado nos termos da filosofia pitagórica. ${ }^{79}$

\subsubsection{O testemunho platônico (Phld. 16c-23c)}

Que Aristóteles tivesse razão em revelar a influência sobre Platão das teorias pitagóricas pode ficar claro pela análise de um trecho central da obra deste último, contido nas páginas do Filebo. A passagem mostrará em que medida Platão considerava o seu esforço para chegar a uma compreensão dos primeiros princípios como uma continuação do pitagorismo, dando assim razão a Aristóteles, quando a indica, na página de Met. $987 \mathrm{~b}$. Ao mesmo tempo revelará que a tradição pitagórica que Platão, no Filebo, mostrará preservar com certa fidelidade, torna-se também um ponto de partida para ele mesmo perseguir seus próprios projetos teoréticos, de maneira especial em busca de uma solução para o problema da unidade e multiplicidade dos existentes. Será assim possível concluir que a platonização do pitagorismo não é simplemente uma tendência acadêmica, mas pode remontar ao mesmo Platão.

as a transposed version of Orphic cosmogony”. Não é o caso de duvidar que esta transposição tenha de fato desempenhado algum papel na definição desta teoria cosmológico-numérica. Não é difícil imaginar, como faz Burkert, que esta doutrina pitagórica possa ser pensada como uma exegese de mitos cosmogônicos órficos. Ainda mais após a recepção no interior da crítica que se ocupa dos pré-socráticos da análoga exegese representada pelo papiro Derveni. Esta hipótese traria fecundas conclusões se compreendida, por exemplo, à luz daquilo que se disse acima, no capítulo terceiro, com respeito às relações entre pitagorismo e orfismo sobre teoria da alma. Por outro lado, anota com razão Kahn (1974: 172) que uma veste cosmogônica para a filosofia é típica de muitos pré-socráticos. Finalmente, a hipótese de Burkert, que não foi recolhida por nenhum outro comentador, é de difícil comprovação e precisaria de outra monografia exclusivamente dedicada a ela.

${ }^{79}$ Aristóteles resolverá esta questão da indistinção entre números e coisas no interior de seu próprio sistema filosófico. No contexto da discussão do sentido do tempo, para resistir ao idealismo platônico que postula a existência dos números separadamente das coisas, introduzirá a distinção entre número numerado e número numerante (Phys. 219b 6-7). Cf. para isso também Rey Puente (2001: 49 e o mais recente 2010). 
É,pois, Burkert (1972:85) que sugere que um lugar entre os mais importantes para compreender a relação entre pitagorismo e platonismo é exatamente a página 16c do Filebo: a passagem introduz o tema da dialética do limitado/ilimitado. Aqui, a procura pela questão maior do prazer é desenvolvida no tema da unidade/ multiplicidade, do um e dos muitos, que marca dramaticamente muitas das preocupações filosóficas pré-socráticas. A dramaticidade do tema é sublinhada pelo prólogo à discussão de Sócrates: "Não poderia haver um caminho mais belo do que este, do qual eu sou amante desde sempre, mas que muitas vezes me fugiu e me deixou sozinho e sem saída" (Phlb. 16b). A solução para a questão vem de longe, tanto em sentido físico quanto em sentido temporal: é apresentada como uma revelação, como um dom dos deuses (dósis theôn) em 16c e como descoberta dos antigos (oi prósthen) em 17d. Trata-se exatamente da conaturalidade às coisas que são do limitante/ilimitado, e da harmonía entre os dois como princípio de "funcionamento" metafísico da realidade:

Um dom dos deuses para os homens: assim, me parece, de um lugar do céu divino um dia foi jogado sobre a terra, por meio de algum Prometeu, junto com um fogo de claridade ofuscante e os antigos (que eram mais valentes do que nós e viviam mais próximos dos deuses) transmitiram para nós esta revelação, isto é, que resultando da unidade e multiplicidade das coisas que são, as coisas que sempre são foram ditas e serão ditas "coisas que são", elas têm em si, por natureza, limite e ilimitado (Phlb. 16c-d).

Trata-se aparentemente de um dom de signo epistemológico, pois é dito imediatamente depois consistir "na maneira como os deuses indicam-nos que se deve aprender e ensinar uns aos outros" (Phlb.16e). O alcance dessa observação será revelado no comentário que se fará logo mais aos fragmentos de Filolau.

A função da introdução, no interior da dupla um-muitos, da dupla limitanteilimitado, afirma com razão Migliori (1993: 98), é claramente aquela de fazer funcionar esta última como uma justificativa ontológica da primeira, no sentido que é a ação do limitante e ilimitado que permite que a realidade seja uma e multíplice. Uma afirmação forte sobre a realidade das coisas que são, portanto..$^{80}$

A afirmação desse método (cf. a imagem do hodós em 16b) dos dois princípios visa, dialeticamente, enfrentar o fato de que, ao contrário, certos "homens sábios de agora" (oi de nûn tôn antropôn sophoí, a construção sintática da expressão não deixa dúvidas em relação à ironia desta) "põem o um ao acaso, passando logo para o infinito", fugindo contemporaneamente das realidades intermediárias (17a). Nesse proceder sem considerar as realidades intermediárias parece estar toda a diferença entre o método dialético e aquele, ao contrário, eurístico. E, como será possível acompanhar, na continuação do diálogo residirá a mesma solução do problema da vida boa entre prazer e conhecimento.

\footnotetext{
${ }^{80}$ Não parece ser o caso de duvidar disso, nem sequer querendo ser demasiado conservadores em relação à expressão "as coisas que sempre dizemos ser coisas que são", como querem ser, entre outros, Mazzarelli (Platone 1991) e Striker (1970): no contexto da estabilidade da predicação, não parece ser este o eixo da questão, e sim, ao contrário, a correspondência dessa estabilidade do ser com as coisas que são. Cf. Migliori (1993: n.96).
} 
Protarco, que parece mesmo não conseguir acompanhar a improvisada guinada metafísica da argumentação, pede água (17a). Sócrates responde, assim, com dois exemplos. $\mathrm{O}$ som emitido pela nossa boca, quando pronunciamos as letras do alfabeto, é escolhido por Sócrates como um exemplo, certamente o mais irritantemente didático possível. ${ }^{81}$ Este som é, ao mesmo tempo, um (mia) e infinita possibilidade (ápeiron au plêthei), para quem o pronuncia (18b). Mas aquilo que nos torna realmente conhecedores da gramática não é o conhecer aquela dupla natureza da infinitude e unidade, e sim, ao contrário, conhecer as quantidades e as qualidades (pósa kai opoîa). ${ }^{82}$

O segundo exemplo escolhido por Sócrates está significativamente ligado ao mundo da música. $\mathrm{O}$ argumento é que conhecer dois tons, um grave e outro agudo, e como terceiro o intermediário, não nos tornaria ainda experts de música:

Porém, meu amigo, quando você terá conhecido o número dos intervalos que existe seja no tom agudo como no grave, e quais são os limites destes intervalos e quantos sistemas resultam de sua conjunção (os predecessores descobriram estes sistemas e os transmitiram para nós, que os seguimos, com o nome de harmonias, e viram que mesmo nos movimentos do corpo verificam-se outras afecções semelhantes e que, sendo mensuradas pelos números, afirmaram que deveriam ser chamadas de ritmos e medidas, e, ao mesmo tempo, que é desta forma que devem ser analisadas as coisas em todos os casos de unidade e multiplicidade); assim, quando você terá compreendido também isso, e então terá se tornado conhecedor de música, e quando terá conseguido e compreendido, analisando-a, qualquer uma das unidades, então terá se tornado profundo e inteligente conhecedor do objeto de sua análise. Mas a infinitude das coisas, a infinita multiplicidade que está em cada uma delas, todo caso the faz incapaz de pensar agudamente e impede que você seja um homem ilustre e de valor reconhecido, caso você não tenha nunca conseguido reconhecer em nenhuma coisa nenhum número $(P h l b .17 \mathrm{c}-\mathrm{e})$.

A análise da música requer, portanto, uma atenta articulação do conhecimento dos limites, dos intervalos e das correlações entre diferentes sons; isto é, em uma palavra, dos números que as constituem.

Os dois exemplos desenham assim uma trama de relações que constitui a "infinitude das coisas e a infinita multiplicidade que está em cada uma delas"; propõem um sistema estruturado que permita uma adequada explicação dessa realidade (Migliori 1993: 108). A descoberta dessa explicação sistemática é atribuída aos predecessores (oi prósthen). ${ }^{83}$ É significativo aqui o uso do termo

${ }^{81}$ Veja-se, de fato, a consequente irritação de Protarco com os kúk $\lambda$ or por meio dos quais Sócrates parece querer enredar - sofisticamente - seus interlocutores (Phlb.19a).

${ }^{82}$ A ideia é, por enquanto, somente acenada, no interior do desenvolvimento do argumento da página do Filebo; será retomada e desenvolvida mais amplamente em seguida, ao longo do mesmo diálogo.

${ }^{83}$ Pace Gaiser (1988: 84), tanto a dialética quanto a teoria dos princípios são indicadas, pelas declarações socráticas no Filebo, como tendo sua origem entre os antigos, e não como criações platônicas. 
systémata para indicar os sistemas de conjunção dos intervalos que são chamados de harmonia: em Aristóxeno o termo irá significar escala musical (2.36). ${ }^{84}$

Enquanto, na economia própria do texto platônico, a proposta de uma vida mista será, enfim, o correspondente ético do funcionamento ontológico da realidade, pois esta mesma é de certa forma mista sob a ação do péras e do apeíron, o que mais importa aqui é anotar que no resumo final da argumentação $(23 c-d)$ Sócrates faz novamente referência a uma revelação divina do limitado e do ilimitado dos entes:

SOCR. Retomemos, então, o que já dissemos hoje.PROT. O quê? SOCR. Não afirmamos, por acaso, que de alguma maneira o deus tem revelado a presença do ilimitado e do limite nas coisas que são? PROT. Claro. SOCR. Colocamos, portanto, estes como dois gêneros, e como terceiro uma certa mistura que resulta dos dois primeiros (Phlb.23c-d).

Deixando por um momento de lado a introdução aqui do gênero misto, o que chama atenção no resumo é a afirmação da revelação divina. Essa referência insistente a uma origem divina pode sublinhar o valor que Platão dá à teoria do limitante e ilimitado. Sócrates havia declarado diversas vezes seu temor para com os deuses nas primeiras páginas do diálogo (12c). Ao mesmo tempo, a revelação não deve ser pensada como algo completo, definitivo - como poderia sugerir certa influência sobre a leitura dos antigos da concepção dogmática da matriz judaico-cristã-islâmica, isto é, das assim chamadas "religiões do Livro". ${ }^{5}$ A revelação, ao contrário, pode ser pensada como algo de origem nobre e que pede para ser continuado: como um compromisso a ser tomado no futuro; não como algo estático, dogmático. ${ }^{86}$

Contudo, a origem divina parece confirmar uma referência direta ao pitagorismo e, de maneira especial, ao seu fundador, Pitágoras, "em ar de divindade” em muitos testemunhos antigos. Entre eles o já citado (2.1) testimonium aristotélico que refere o segredo dos pitagóricos: "dos seres viventes dotados de razão, um é o deus, o outro é o homem, o terceiro possui a natureza de Pitágoras" (Iambl. VP: $31=$ Arist. Fr. 192 Rose $=14$ A7 DK). Como também o testemunho de Aristóxeno, quando "afirma que Pitágoras derivou a maior parte de suas doutrinas éticas (éthica dógmata) da sacerdotisa Temistocleia de Delfos" (fr. 15 Wehrli = 14 A3 DK). Com a consequência de que Prometeu representaria assim Pitágoras e sua tradição. ${ }^{87}$

${ }^{84}$ Cf. para esta citação Huffman (1993: 162).

${ }^{85}$ Ainda que este tipo de interpretação da revelação, mesmo no interior das religiões do livro, possa receber críticas e ser, de certa forma, aberto, é ele quem marca fundamentalmente a recepção da normal destas tradições até as dramáticas explosões de diversos fundamentalismos em nossos dias.

${ }^{86}$ Concorda com isso Burkert (1972: 90): "For Plato's affirmation of the divine origin of the doctrine of Limit and Unlimited is more than a glittering sequin on the fabric of the exposition. It signifies that its truth is beyond doubt; and Plato feels that this imposes on him the obligation to grasp the truth of this idea and its all-encompassing significance. Such a divine revelation is not something finished and complete, but a task to fulfill”.

${ }^{87}$ Quanto ao reconhecimento de Pitágoras em Prometeu, concordam Hackforth (Philebus 
Que a fonte platônica para essas passagens do Filebo seja pitagórica recebe também outra confirmação na seguinte observação: na passagem acima citada de $17 \mathrm{c}-\mathrm{d}$, aliada à referência mais genérica aos antigos, há de fato clara tomada de posição musicológica em favor da teoria musical pitagórica: ritmos (rýthmoi) e medidas (métra) - segundo esses mesmos antigos -, ou seja, os intervalos musicais são medidos pelos números (arithmôn metrêthenta). É interessante notar que a mesma referência é utilizada por Platão em Resp. VII, 530d: os pitagóricos são arrolados para afirmar a irmandade da astronomia com a música: em contraste com uma maneira imperfeita e literalmente "de ouvido" com a qual certas pessoas (os músicos) "colocam os ouvidos antes da mente" para compreender a harmonia musical, os pitagóricos "agem exatamente como os astrônomos": estudam os números que resultam dos acordes, mesmo não chegando aos números em si, para definir quais seriam consoantes e quais não. ${ }^{88}$

Essas passagens do Filebo, centrais para a definição da dialética do limitado/ilimitado, revelam as raízes pitagóricas da teoria dos princípios platônica e - como tais - constituem um achado pré-aristotélico de filosofia pitagórica. Raízes afirmadas e reconhecidas pelo próprio texto platônico, nas maneiras acima descritas, e que - como fontes para a elaboração filosófica platônica - são reinterpretadas pela Academia, que se percebe nesse sentido como continuadora e mediadora do esforço dialético-metafísico pitagórico.

Todavia, para além do reconhecimento das fontes pitagóricas para a construção do argumento dialético-ontológico, a construção da dialética no Filebo é fruto da concepção filosófica platônica. Como demonstra o fato de, no resumo conclusivo de toda a argumentação (cf. acima, 23c), Platão introduzir um terceiro elemento ao lado da oposição limitado/ilimitado: trata-se de "um algo misturado, misto" (en ti summisgómenon) originado de ambos. E ainda um quarto elemento: a causa (aitía) dessa mesma mistura.

A argumentação desenvolve-se aqui em pleno âmbito teorético platônico. Apesar de reconhecer as raízes pitagóricas (mais precisamente filolaicas, se poderia agora afirmar) da teoria do limitado/ilimitado, Platão coloca-se em uma perspectiva bem diferente do ponto de vista teórico. Um desenvolvimento que, mesmo que possível e de alguma forma normal no panorama da história da filosofia, não obteria, por assim dizer, a autorização do próprio Filolau.

A construção desse âmbito teorético platônico corresponde aos primeiros movimentos daquela que se chamou, ao longo das páginas anteriores, de mediação platônica do pitagorismo. No caso específico da teoria dos princípios, conforme aparece na página estudada do Filebo, Platão opera uma transição

1945: 21), Philip (1966: 38), Taylor (1968: 639), Burkert (1972: 85), Waterfield (Plato 1982: 60), Casertano (1989: 92) e Gosling (1999: 55).

${ }_{88}$ É curioso notar que a resposta de Glauco remete novamente ao mundo do divino: $\Delta \alpha \iota \mu o ́ v i o v ~ \pi \rho \alpha ́ \gamma \mu \alpha$ ! - afirma Glauco - seria tal caminho até os números enquanto tais (Resp. VII: 531c). Burnet (1908: 228) e Burkert (1972: 87) concordam em reconhecer nos oi $\pi \rho o ́ \sigma \theta \varepsilon v$ os pitagóricos mencionados na República. Mais céticos são Barbera (1981: 395-410) e Centrone (1993: 112). No entanto, até Frank (1923: 155), dessa vez, concorda com Burkert. 
O pitagorismo como categoria historiográfica

conceitual: transformando o ilimitado em sua raiz pitagórica, pensado como pluralidade espacial e numérica, em indefinido, abre a porta para a teoria das formas, chegando, na escala dialética, até a díade indefinida.

A essa mesma doutrina do limitado/ilimitado refere-se o prólogo daquele que deve ter sido o livro de Filolau (44 B1 DK). 


\subsection{Os fragmentos de Filolau}

\subsubsection{Ilimitados/limitantes}

A proximidade do fr. 1 de Filolau com a página do Filebo anteriormente citada foi obviamente notada já na antiguidade: Damáscio de Damasco, último diádoco da Escola de Atenas, afirmava que "o que é deriva do limitado e do ilimitado, como diz Platão no Filebo e Filolau nos livros sobre a Natureza" (De principiis, I: 101,3).

Diversas aproximações também entre a lectio de Aristóteles e os testemunhos de Filolau foram indicadas nas páginas anteriores. Essas aproximações, somadas ao caráter de exceção dos testemunhos aristotélicos perante a categorização majoritária platonizante do pitagorismo antigo, tornarão a análise dos fragmentos de Filolau a pedra angular do presente capítulo. De um lado, por permitirem comprovar textualmente o processo de formação da recepção acadêmica da matemática pitagórica; por outro lado, por constituírem sinais inequívocos de uma teoria dos números pitagórica datada ainda no século $\mathrm{V}$ a.C, teoria esta que Aristóteles demonstra conhecer.

É o caso de iniciar a análise voltando brevemente à questão da autenticidade do livro de Filolau. Para além do já citado (4.1.3.2) ceticismo de Bywater (1868: 21-53), Burnet (1908: 279-284), Frank (1923: 263-335) e Lévy (1926: 70ss), a proximidade com o testemunho aristotélico faz também autores mais recentes, como é o caso de Raven (1966: 98), Kahn (1974) e Barnes (1982), levantarem a hipótese de que os fragmentos de Filolau seriam uma falsificação com base no testemunho aristotélico. Ainda que seja tecnicamente possível imaginar que alguém tenha falsificado o livro de Filolau após o testemunho aristotélico e baseando-se neste, o procedimento seria inédito no interior da pseudoepigrafia do pitagorismo, normalmente tendente, ao contrário, a platonizar os conceitos pitagóricos. De fato, Burkert (1972: 238ss.), Huffman (1993: 23) e mais recentemente também Kahn (2001: 23) concordam em considerar autênticos ao menos os primeiros sete fragmentos da coleção de Diels-Kranz (44 B1-7 DK). Novamente, a exceção que a lectio de Aristóteles representa sugere que a falsificação dos fragmentos seria lectio difficilior. Disso deriva, por consequência, que é mais fácil que seja verdadeiro o contrário, isto é, que esses fragmentos de Filolau sejam autênticos e, como tais, fontes de Aristóteles.

Desses sete, exatamente os fragmentos 1, 2, 3 e 6 dizem diretamente respeito ao tema do limitado/ilimitado que se examinou há pouco no Filebo.

Assim, inicia-se o livro de Filolau, portanto:

A obra Sobre a Natureza iniciava com a seguinte afirmação: a natureza no ordenamento do mundo resultou do acordo de coisas ilimitadas e limitantes, e assim o inteiro cosmos e todas as coisas que estão nele (44 B1 DK). 
Diversos sinais textuais parecem confirmar tratar-se aqui de um fragmento original: a partir do título da obra, Perí Physeos, até a presença da partícula dé. ${ }^{89}$

Para além do título da obra, que poderia ser simplesmente convencional, a recorrência de termos como phýsis e kósmos situam o fragmento no interior da já secular tradição pré-socrática, operando quase uma síntese (toda pré-socrática) entre a cosmologia milesiana do ilimitado e a concepção da perfeição do ser no limite de matriz eleata, fundamentalmente como resposta ou diálogo in progress com filosofias como as de Anaxágoras e Parmênides.

Contudo, é especialmente a introdução aqui dos conceitos de ápeira e peiránonta a chamar a atenção. $\mathrm{Na}$ busca da definição de uma phýsis en tô kosmô, de uma racionalidade interna à natureza, que poderíamos tomar como sinônimo da própria arché pré-socrático, Filolau não afirma - como se poderia imaginar, a partir de testemunho aristotélico - que "tudo é número", e sim que há um "acordo de coisas ilimitadas e limitantes".

Há um detalhe terminológico que merece ser destacado. ${ }^{90}$ Filolau não utiliza, propriamente, os termos ilimitado/limitado, e, sim, sempre somente o plural: ápeira e peiránonta, isto é, em uma tradução filologicamente mais fiel e filosoficamente mais fecunda "coisas ilimitadas e limitantes", por se tratar, este último, de um particípio presente do verbo perainô. Ao contrário, tanto no Filebo de Platão quanto na Metafísica de Aristóteles, os termos são pensados e utilizados no singular: o nome péras para "limite" ou o particípio passivo do verbo perainô, peperasménon, para "limitado" e o adjetivo neutro singular ápeiron, precedido de artigo (tó ápeiron), o "ilimitado", todos eles no singular. A insistência no fato de que esses "princípios" sejam plurais indica diretamente o fato de eles não serem compreendidos por Filolau como princípios metafísicos à maneira que serão compreendidos em seguida por Platão e Aristóteles, que por exatamente esse motivo preferem utilizar o singular. ${ }^{91}$

É o que aparece no fr. 2, que, utilizando a mesma terminologia do "acordo" de "ilimitados/limitantes" do fr. 1, explicita mais claramente qual devia ser o alcance dessa teoria:

De Filolau, sobre o ordenamento do mundo: necessariamente as coisas que são devem ser todas ou ilimitadas ou limitantes, ou ilimitadas ou limitantes ao

${ }^{89}$ Boeckh (1819: 45) havia sugerido que não podia se tratar aqui do início do livro de Filolau exatamente pela presença do $\delta \varepsilon ́$ no início da sentença. $O \delta \varepsilon ́$ sugeriria haver algo que foi dito antes disso, e por este motivo não poderia estar no prólogo do livro. Todavia, Burkert (1972: 252), seguido por Huffman (1993: 95), argumenta que a presença do ઈé no início de uma obra era prática comum entre os autores do século $\mathrm{V}$ aEC (cf. Heráclito, fr. 1 e Íon, fr. 1), e que devia se referir ao título desta. Contrariamente à tese de Boeckh, portanto, sua presença seria um bom motivo para considerar esse fragmento como autenticamente pré-socrático.

${ }^{90}$ Cf. para essas observações, Burkert (1972: 253ss.) e Huffman (1993: 39).

${ }^{91}$ Cf., mais em geral, para essa recepção de Aristóteles dos "princípios" dos pré-socráticos especialmente Cherniss (1935: 374ss.), que considera os testemunhos deste último "errors of interpretation which influenced Aristotle's general attitude toward the Presocratics and which continue to have an effect on modern historians". 
mesmo tempo; limitantes somente, porém, ou somente ilimitadas não poderiam ser; considerando que mostram evidentemente serem as coisas nem todas limitantes nem todas ilimitadas, é claro, portanto, que, do acordo de limitantes e ilimitados, tanto o ordenamento do mundo quanto as coisas nele resultaram. É demonstrado pelos fatos que as coisas que derivam dos limitantes limitam, e que as que derivam dos limitantes e ilimitados limitam ou não limitam, e que aquelas que derivam dos ilimitados parecem ilimitadas (44 B2 DK).

A argumentação deste fr. 2 não deixa dúvidas sobre o fato de que limitantes e ilimitados não devem ser pensados - em Filolau - como princípios abstratos e separados do mundo, mas como atributos da própria realidade. Uma confirmação disso é a insistência, no interior do fragmento, de como limitantes/ilimitados são evidentes, como são de alguma forma manifestos no mundo. Por quatro vezes Filolau insiste nisso, utilizando termos ligados ao campo semântico do aparecer manifesto: a) phainetai... eónta: "mostram evidentemente serem as coisas que são"; b) dêlon: "é claro que do acordo..."; c) dêloi... en tois érgois: "é demonstrado pelos fatos..."; d) phanéontai: "parecem [ilimitadas]". Bem longe, portanto, de uma falsificação platonizante.

Há algo de significativo também no ritmo do fr. 2. A ladainha dos limitantes/ ilimitados lembra de perto um estilo encantatório. Mais um sinal, certamente, do profundo enraizamento do texto filolaico no contexto da produção filosófica pré-socrática. ${ }^{92} \mathrm{~A}$ expressão das ideias é aqui performática: é como se a repetição da harmonia entre limitantes e ilimitados quisesse fazer ecoar nas palavras o som dessa mesma harmonia, tornando-a assim presente, pela força das palavras. $\mathrm{O}$ fragmento, de certa forma, pede para ser ouvido em seu ritmos e sonoridade próprios. Esse estilo oracular insere o texto filolaico também na tradição esotérica pitagórica (e não somente pitagórica), bem descrita por Gemelli Marciano:

Nos textos esotéricos de Heráclito, Parmênides, Empédocles, a recepção dos mýthoi e dos lógoi é expressa unicamente pelo verbo akoûein, ouvir. Que não seja simplesmente a reprodução artificial de uma situação de transmissão oral, mas de uma situação efetiva, resulta especialmente evidente no momento em que a palavra é expressamente definida como uma entidade física que penetra no corpo provocando mutações. $O$ poder de ação e de transformação exercido pela palavra em sua fisicidade é, por outro lado, o elemento fundamental dos encantamentos e das fórmulas mágicas, como Górgias testemunha explicitamente em seu Elogio de Helena (Gemelli Marciano 2007: 449-450). ${ }^{93}$

${ }^{92}$ Burkert (1972: 252 n67) cita os fragmentos 6 de Anaxágoras e 8 de Parmênides como exemplos desse mesmo estilo.

93 Orig.: "In den esoterischen Texten Von Heraklit, Parmenides und Empedokles wird die Rezeption der Mýthoi und Lógoi ausscheliesslich mit dem Verb akoúein, hören, ausgedrückt. Dass es sich dabei nicht einfach nur um die gekünstelte Nachahmung einer oralen Vermittlungssituation, sondern um ein reales Geschehen handelt, wrid vor allem an dem Stellen deutilich, an denen das Wort explizit als physische Entität aufgefasst wird, dir in den Körper endringt und dort Änderungen hervorruft. Die mächtige Wirkung und Veränderun, die das Wort qua seiner Körperlichkeit ausübt, ist im übrigen das grundlegende Element aller 
A pluralidade e a naturalidade (no sentido de serem atributos da phýsis entendida como natureza real) dos ilimitados/limitantes são confirmadas também pelo fato de Filolau recusar-se a definir ou enumerar exatamente o que entende ou quais realidades considera como limitantes e ilimitadas; isto é, a dar uma lista de princípios limitantes e outra de princípios ilimitados, como poderiam ser a água, o fogo etc.

De fato, na primeira parte do fr. 6, assim expressa-se:

Sobre a natureza e a harmonia, as coisas estão assim: o ser das coisas, que é eterno, e a própria natureza requerem um conhecimento divino, e não humano. Além disso, seria impossível que alguma das coisas que são fosse por nós conhecida se não tivesse como fundamento o ser das realidades que formam o mundo ordenado, isto é, as limitantes e as ilimitadas (44 B6, 1-8 DK).

Longe de tratar-se simploriamente de um exemplo da "modéstia característica do pensamento arcaico" (Kahn 1974: 173), ${ }^{94}$ aqui a referência ao divino - analogamente presente nas páginas acima citadas do Filebo apresenta-se mais como uma afirmação em polêmica antijônica. No sentido de que a definição da realidade última encontra-se tão "além das capacidades de conhecimento humano", seria mais adequado contentar-se em definir que todas as realidades devem ter surgido, de alguma forma, de limitantes e ilimitados, no lugar de imaginar desajeitadamente archaí como a água, o ar etc. Se alguma coisa será então cognocível, esta será a realidade das coisas visíveis, o mundo físico, portanto. Provavelmente por esse motivo, Aristóteles (Met. 989b), como se viu, afirmava que a filosofia pitagórica explicava melhor os entes físicos, ainda que os princípios por eles desenvolvidos se prestassem mais para o nível suprassensível.

É possível ouvir aqui, no fr. 6, ecos da mesma preocupação que Platão parece colocar na boca de Sócrates quando polemiza com "os sábios de agora" (Filebo 17a), pelo fato de estes passarem de maneira demasiadamente apressada do um para o infinito, sem considerar as realidades intermediárias; isto é, em pretensa continuidade com a tradição pitagórica, sem considerar a determinação numérica. Pois é exatamente aquilo que está no meio que se apresenta, para Platão, como decisivo para a compreensão do mundo. Ainda que Filolau, "inocente das distinções posteriores" (Huffman 1993: 52), esteja aqui revelando mais simplesmente uma polêmica com Anaximandro, por exemplo, mas também com Anaxágoras e suas archai indeterminadas.

A polêmica antipluralista coloca Filolau de acordo com Parmênides. Semelhante preocupação epistêmica é confirmada também pelo fr. 3: "De maneira alguma seria possível conhecer algo, se todas as coisas fossem ilimitadas" (44 B3 DK). A aproximação com a filosofia eleática é evidente também no uso do termo estô, no fr. 6, que foi traduzido por "ser": o ser das

magischen Formeln und Zauber, wie Gorgias im Helena-Enkomion ausdrücklich erklärt”.

${ }^{94}$ Orig.: "epistemic modesty that is custumary in archaic thought" (Kahn 1974: 173). 
coisas (estô tôn pragmáton) e que é definido aidíos, eterno. Como no Poema de Parmênides, também em Filolau o ser é, como tal, incognocível, a menos que não intervenha uma revelação divina. É certamente preciso - mais uma vez - resistir à tentação de compreender estô a partir das categorias aristotélicas: não se trata aqui da matéria indiferenciada ou a causa material à qual o limiteharmonia ou causa formal dará forma. Ao contrário, estô é constituído por ambas as realidades, as ilimitadas e as limitantes, e a polêmica de Filolau, como se viu, é interna à dialética pré-socrática. É este certamente mais um sinal da antiguidade da doutrina. ${ }^{95}$

O caminho de Filolau é certamente original, mesmo no interior da filosofia pré-socrática, pois por um lado não expressa uma posição monista, uma vez que o ser resulta da pluralidade de ilimitados/limitantes; por outro lado, o ceticismo epistemológico do fr. 6 é moderado pela possibilidade de conhecer ao menos duas coisas: isto é, esta mesma pluralidade e a harmonía que a mantém unida, acordada.

É exatamente a harmonía, o acordo (harmóchthe) entre os limitantes/ ilimitados, em última análise, que permite explicar o surgimento da realidade, como testemunham tanto o fr. 1 quanto o fr. 6. A introdução desse terceiro elemento conectivo, harmonizador, dos limitantes/ilimitados, faz Filolau começar a procurar exemplos de como as coisas são "acordadas". ${ }^{96}$ Primeiro entre todos, o fogo parece um bom exemplo no fr. 7: "o primeiro acordado, o um no meio da esfera, é chamado fogo" (44 B7 DK). ${ }^{97} \mathrm{O}$ fogo parece prestar-se bem às intenções explicativas de Filolau: ao mesmo tempo símbolo do ilimitável, seu estar cosmologicamente no centro da esfera o delimita claramente. ${ }^{98} \mathrm{E}$ possível que exatamente essa referência filolaica ao fogo como um no centro da esfera possa explicar a citação prometética relativa às origens pitagóricas da teoria do limitante/ilimitado no Filebo. Ainda que seja possível trata-se, aqui, de simples assonâncias conceituais. ${ }^{99}$

Contudo, o âmbito exemplificativo que mais interessa, em relação tanto ao testemunho aristotélico quanto à recepção platônica do Filebo, é o da escala musical. Na segunda parte do fr. 6, é definida uma grandeza do acordo (barmonía mégethos), no interior da descrição da escala diatônica pitagórica (a mesma que é pressuposta no Timeu 35b):

${ }^{95}$ Concordam com esta interpretação Burkert (1972: 256) e Kahn (1974: 173). Huffman

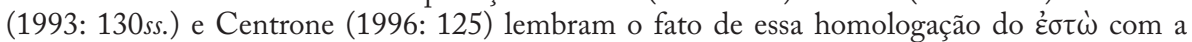
causa material aristotélica ser uma das características da literatura pseudoepigráfica helenística.

${ }^{96}$ Frank (1923: 304ss.) observa que exatamente esta necessidade de fornecer provas de seus argumentos seria um sinal inequívoco de que se trata, no caso dos fragmentos de Filolau, de uma falsificação helenística. Todavia, o que se dirá em seguida sobre os métodos das archaí que Filolau compartilha com autores do século V a.C como Hipócrates de Quios e Heródoto deverá sugerir exatamente o contrário.

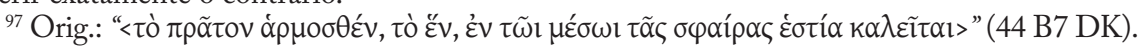

${ }^{98}$ Cf. outros testemunhos doxográficos paralelos em A16 e A17.

99 Outros exemplos surgem do âmbito médico-antropológico, como é o caso de um paralelismo significativo entre o fogo e o calor da vida (Huffman 1993: 45). A economia destas páginas torna impossível uma análise detalhada dessas referências. 
A grandeza do acordo é formada pelos intervalos da quarta e de quinta. A quinta é maior do que a quarta por um tom. De fato da corda/tom mais alta à corda do meio é uma quarta, da do meio à ultima, é uma quinta. Da última à terça é uma quarta, e da terceira à mais alta uma quinta. $\mathrm{O}$ intervalo entre a do meio e a terceira é um tom (9:8), a quarta é expressa pela relação epítrita (4:3) e a quinta pelo emiólio (3:2), e a oitava pelo duplo (2:1). Assim, o acordo (escala harmônica) compreende cinco tons e dois semitons menores; a quinta, três tons e um semitom menor; a quarta, dois tons e um semitom menor (44 B6, 16-24 DK).

Aqui, a imagem de limitantes e ilimitados - como na teoria musical e no exemplo que Platão utiliza no Filebo - é aquela de uma corda musical, um contínuo ilimitado, na qual são definidos, limitados, intervalos específicos. ${ }^{100}$ Mais uma vez, a harmonia, o acordo, não devem ser nunca confundidos com o limitante: o acordo funciona pelo número, mas o número e o acordo não se substituem aos limitantes.

A passagem, no interior do mesmo fr. 6, de uma primeira parte cosmológica para uma segunda parte musical não surpreende, especialmente à luz do testemunho aristotélico já citado, que conecta exatamente essas duas dimensões no resumo da teoria numérica pitagórica: "Pensavam serem os elementos dos números os elementos de todas as coisas e que a totalidade do céu é harmonia e número" (Met. 986a3).

A possibilidade, indicada pelo fragmento de Filolau, de numerar os intervalos consoantes remete novamente para o tema central deste capítulo, isto é, aquele do número pitagórico. É significativo que até este momento, no interior dos fragmentos de Filolau, o número como tal não apareça. $\mathrm{E}$ todavia, como o fr. 6 acima testemunha, a tematização do número não é totalmente ausente no interior dos fragmentos.

Resta perguntar-se, portanto, qual seria a função dos números no interior do sistema filolaico; e qual a relação destes com a dupla limitantes/ilimitados.

\subsubsection{O papel dos números em Filolau}

É o fr. 4 de Filolau a indicar mais precisamente qual devia ser o papel dos números em sua filosofia:

E, de verdade, todas as coisas que são conhecidas têm número. Pois desta forma não é possível que alguma coisa seja pensada ou conhecida sem este (44 B4 DK).

A expressão arithmón échonti, "têm número", deve ser compreendida, no rastro da compreensão grega dos arithmoi como pluralidade ordenada, no sentido de que a realidade é constituida por uma pluralidade ordenada. "Todas

${ }^{100}$ Para um estudo aprofundado da relação entre a teoria musical grega e os instrumentos de cordas, veja-se Rocconi (2003), além do recentíssimo estudo sobre o monocórdio de Creese (2010). 
as coisas têm número" significa, na prática, "todas as coisas são, basicamente, número" (Burkert 1972: 266s). ${ }^{101}$ Todavia, a segunda parte do fragmento não deixa dúvidas em relação a qual deveria ser o papel dos números em Filolau. A função destes é precisamente epistemológica: graças ao fato de a realidade "ter número" é que ela pode ser conhecida, enquanto é passível de uma descrição numérica.

$\mathrm{O}$ argumento epistemológico do fr. 4 foi obviamente considerado, desde Bywater (1868: 35), uma prova da inautenticidade dos fragmentos filolaicos. Todavia, diversos comentadores chamaram atenção mais recentemente para o paralelo interesse fundamentalmente epistemológico em filósofos présocráticos anteriores a Filolau, como seria o caso da própria filosofia de Parmênides. ${ }^{102}$ Huffman (1993: 67) anota com razão que os números respondem diretamente às exigências epistemológicas parmenídicas, as mesmas que no Poema são postas como "sinais" no caminho do ser (28 B8 DK): para que possa haver conhecimento, o objeto deverá ser ingênito, eterno etc. Em suma, algo limitado. Todavia, como se viu acima, Filolau deseja fugir da imobilidade do ser eleático. Exatamente a introdução dos números parece a melhor solução para manter, de um lado a pluralidade, do outro a determinação do ser. As relações matemáticas expressas pela escala musical do fr. 6, de fato, são perfeitamente determinadas e podem ser encontradas na realidade. Ainda que a realidade se revele primariamente como harmonia de limitantes/ilimitados, portanto, e não como número, este último pode ser considerado como sinal (à maneira de Parmênides) do ser das coisas que são.

É o que sugere o fr. 5, que utiliza exatamente o verbo semaino para descrever como a realidade expressa os números:

O número possui duas espécies que lhe são próprias: o ímpar e o par; a terceira, resultante da mistura de ambos, é o parimpar. De cada uma das duas espécies existem muitas formas, das quais cada coisa enquanto tal dá sinais (44 B5 DK).

As três espécies dos números, propriamente, não correspondem à realidade, e sim a sinais emitidos pela realidade para que esta possa ser conhecida. A bem ver, portanto, Filolau não diz que a realidade como tal é número (como dirá Aristóteles) e sim que é cognoscível pelo número, desde que se captem os sinais que ela emite. A realidade mesma é de fato constituída por coisas limitantes e coisas ilimitadas, das quais os números podem ser considerados sinais. Aqui reside talvez a maior originalidade do pensamento de Filolau: a introdução da dupla de princípios limitantes/ilimitados como princípios explicativos da realidade, e não como já de alguma forma algo real. Uma perspectiva mais epistemológica do que ontológica, portanto. Bem longe de

${ }^{101}$ Novamente, dessa forma, se poderia confirmar a afirmação de Aristóteles de que, para

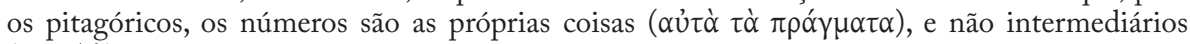
$(\mu \varepsilon \tau \alpha \xi \grave{u})$, conforme Platão.

${ }^{102}$ Cf. especialmente Mourelatos (1970) e Kahn (1969); e mais recentemente Curd (1998) e Robbiano (2006). 
tratar-se simplesmente de "uma mistura de mito e fisiologia" (Burkert 1972: 350). ${ }^{103}$

E, todavia, o fr. 5 sugere poder haver, em última análise, uma correspondência entre estes dois níveis, o ontológico (limitantes/ilimitados) e epistemológico (par-ímpar). A introdução de uma terceira espécie, de fato, o artiopéritton, o "parímpar", pode corresponder na ordem argumentativa à introdução da harmonía para a dupla limitantes/ilimitados. É o que sugere o próprio Aristóteles, conforme foi antecipado acima, quando propõe uma direta correspondência entre as duas duplas: "afirmam como elementos constitutivos do número o par e o ímpar; dos quais o primeiro é ilimitado e o segundo limitado. $\mathrm{O}$ um deriva de ambos os elementos porque é par e ímpar ao mesmo tempo" (Met. 986a 17-19). Aristóteles explicita mais precisamente o sentido dessa correspondência entre par e limitado e ímpar e ilimitado na Física (203a):

Para eles [os pitagóricos], o ilimitado é o número par. Este, de fato, quando interceptado e limitado pelo ímpar, torna presente a indeterminação aos entes. Sinal disso é o que acontece com os números; de fato, conforme sejam colocados ou menos os gnômons em torno ao um, a espécie (do número) permanece uma só ou, ao contrário, torna-se sempre diferente (Phys. 203a = 58 B28 DK).

A explicação aristotélica pode ser facilmente visualizada a partir do momento em que se utilize a aritmética dos pséphoi de Eurito, acima citada. ${ }^{104}$ Colocando de fato um gnómon, um esquadro para desenhar ângulos retos, em volta do um ou do dois respectivamente, resultam duas séries diferentes de números: os pares e os ímpares. $\mathrm{O}$ esquadro que circunscreve o um irá sempre interceptar números ímpares, resultando sempre em figuras quadradas. $\mathrm{O}$ esquadro que circunscreve os números pares, ao contrário, irá sempre desenhar retângulos, isto é, figuras geométricas de lados sempre diferentes, conforme a figura abaixo:

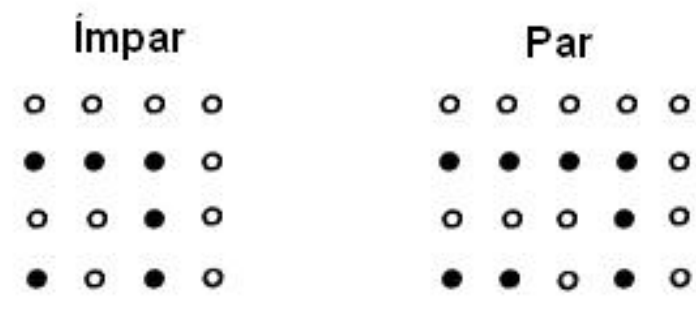

${ }^{103}$ Orig.: "melánge of myth and physiología".

${ }^{104}$ Eurito é considerado, pela doxografia, discípulo de Filolau (D. L. Vitae III. 6; VII. 46). 
Para além da indistinção entre plano numérico e plano cosmológico da qual Aristóteles se queixava (cf. acima: Met. 990a18-22), o testemunho de Física 203a acaba confirmando a autenticidade de certa correspondência, em Filolau, entre os princípios ilimitados/limitados e os números. É significativo também que à harmonia, citada por Filolau na segunda parte de seu fr. 6 sobre as proporções numéricas das escalas musicais, é atribuída uma grandeza (mégethos). De certa forma, é possível imaginar que Filolau estivesse pensando a harmonia entre limitantes e limitados como algo que pudesse ser ele mesmo expresso numericamente.

Contudo, é ainda o fr. 5 de Filolau a não autorizar a levar essa correspondência muito longe, pois a realidade semainei, "dá sinais" dos números pelos quais ela pode ser contada ("têm números", diz no fr. 4), isto é, explicada. Porém, os números não são a realidade e menos ainda coincidem com os princípios ilimitados/limitantes.

É verdade que o uso da aritmogeometria por Filolau é inegável, como a explicação de Aristóteles (Phys. 203a) sugeriu. O próprio testemunho A7a declara a proeminência atribuída por ele à geometria sobre todas as outras ciências: "a geometria é princípio e pátria-mãe das outras ciências" (44 A7a DK). Aqui, a geometria é dita ser arché das ciências, da mesma forma como a cidade-mãe é arché de suas colônias: isto é, como causa e princípio explicativo de sua existência.

Todavia, o interesse de Filolau pelos números é fundamentalmente por estes como princípios explicativos da realidade, no interior daquela nova forma de investigação que foi chamada de método das archaí: uma metodologia de pesquisa que busca os princípios suficientes para a explicação dos fenômenos que ocupa tanto historiadores quanto filósofos, geômetras e médicos ao longo do século $\mathrm{V}$ a.C. ${ }^{105}$

Prova disso é a já citada passagem do Anônimo Londinense (44 A27 DK). Nela, Filolau afirma primeiramente que o corpo "é constituído de calor", em interessante paralelo com o fragmento sobre o fogo no centro da esfera (44 B7 DK), que indicaria uma correspondência entre cosmologia e medicina que remete para o pensamento macro-microcósmico arcaico, conforme foi considerado acima em relação à embriologia. Porém, em um segundo momento, chama archai do "surgimento das doenças", respectivamente "bílis, sangue e catarro". Huffman (1993: 289) afirma que a argumentação aqui atribuída a Filolau incorre em uma contradição: como indicar três diversas archaí para as doenças, sendo que, no início do mesmo testemunho, Filolau afirmaria serem nossos corpos constituídos pelo único princípio, o calor? Não seria mais coerente atribuir ao mesmo princípio (o calor) a origem das doenças?

${ }^{105}$ É o caso de remeter a um meu estudo anterior para o detalhamento desse método das ópxớ e suas referências. Cf. Cornelli (2003c). Cf. para esta referência também Burkert (1972: 420: "From about the middle of the fifth century, it is clear that mathematics is a center of intellectual interest. Almost all the important thinkers are concerned with mathematical questions") e Huffman (1993: 78-92). 
Contudo, o procedimento argumentativo de Filolau é análogo àquele que este desempenha em relação aos números: enquanto o calor é princípio suficiente para explicar embriologicamente o surgimento do ser vivente, para compreender a origem das doenças são necessários, ao contrário, três diferentes princípios. Da mesma forma - esta é a tese que se quer defender - o fato de a realidade ser constituída por ilimitados e limitantes não significa que estes possam explicar todas as coisas; pois a realidade tem também números, e com suas séries e relações os números são suficientes para explicar diversos fenômenos, entre eles as escalas musicais do fr. 6.

$\mathrm{O}$ uso dos números como princípios explicativos, em sentido mais epistemológico que ontológico, é o argumento mais forte de Huffman contra a lectio de Burkert da teoria dos números de Filolau, que evidencia suas características fundamentais de misticismo dos números. ${ }^{106} \mathrm{~A}$ base da discórdia está na existência de testemunhos de Filolau que indicariam essa abordagem numerológica. É certamente o caso de A14, que atribui figuras geométricas a determinadas divindades, e que desde Tannery (1899) é associado ao primeiro aparecimento da astrologia na Grécia. Resquício dessa mesma numerologia poderia estar no próprio testemunho de Aristóteles da associação de determinados números a propriedades e entidades como a justiça, a alma ou o intelecto (Met. 985b27-32, cf. acima). Na mesma linha, Filolau refere-se no fr. 20 ao número sete como número "virgem" e "sem-mãe" (44 B20 DK). ${ }^{107}$

Essas observações, somando-se ao fato de os fragmentos de Filolau não revelarem grandes descobertas ou avanços em relação a teorias matemáticas de seus contemporâneos, sugerem que seria outro o uso que ele faria dos números.

Em contrapartida, a tese de Huffman incorre também em dificuldades quando aplicada ao âmbito agora tratado da embriologia e medicina do Anônimo Londinense pelo fato de Filolau não se referir em algum momento aos números para explicar ambos os campos. Isto é ainda mais significativo quando se olha para o fato de que o uso da matemática no próprio corpus hipocrático é bastante atestado, notadamente em relação aos ciclos da gravidez e às diversas fases das doenças. ${ }^{108} \mathrm{De}$ alguma forma, parece que o "programa de

${ }^{106} \mathrm{C}$. para isso o que foi dito acima (1.8) em relação ao uso do termo aritmologia para indicar mais precisamente a tradição numerológica pitagórica. Para amplo estudo sobre a história da tradição da aritmologia, cf. Robbins (1921). Para recente avaliação crítica da relação entre a aritmologia pitagórica e o desenvolvimento da matemática grega antiga, cf. Cambiano (1992).

${ }^{107}$ Ainda que francamente destemperada, a resenha crítica de Kingsley (1994) ao livro de Huffman sobre Filolau dedica-se exatamente a questionar o excessivamente rápido descarte (dismiss) de A14, e da referência astrológica nele contida, como uma falsificação pós-platônica. Huffman argumenta que esta referência seria uma elaboração a partir do Timeu de Platão. Kingsley responde que a influência da astrologia babilônica sobre a Grécia do século $\mathrm{V}$ aEC foi amplamente provada e que, portanto, seria esta a origem da temática em Filolau (e depois em Platão). O destempero da crítica de Kingsley é bem resumido na frase final da resenha: "Huffman presents a picture of him [Philolaus] ultimately as false as any Philolaic forgery in antiquity" (1994: 296).

${ }^{108}$ Lloyd (1989: 257) confirma: "Great importance is attached by many Hippocratic authors to the study of numerical relationships in connection with the determination of periodicities, notably in two types of context: (1) pregnancy and childbirth; and (2) the phases of diseases, 
Filolau" (Huffman 1993: 74) de busca da estrutura numérica da realidade não tenha sido levado de fato a cabo, se é verdade que no tópico da embriologia e da medicina não há alguma referência a esta pesquisa. ${ }^{109}$

É o caso de concluir que, no limite, a dúvida sobre qual seria mais especificamente o papel dos números na obra de Filolau não poderá ser esclarecida definitivamente, em razão de seu caráter fragmentário. E, por esse motivo, tanto a tese epistemológica quanto aquela numerológica devem ser consideradas ambas válidas. Contudo, não é certamente o caso de concordar com a avaliação displicente de Philip (1966: 32) pela qual, mesmo que os fragmentos de Filolau fossem autênticos, "não seriam capazes de resolver nossos problemas. Pois estes revelam um pensador de não grande estatura, cujos interesses foram periféricos". ${ }^{110}$

Merece ainda ao menos uma breve menção, pelo interesse historiográfico em relação àquela que deve ter sido a filosofia dos números de Filolau, a referência tradicional que se faz à crise dos incomensuráveis, ou irracionais. ${ }^{111}$ Knorr (1975: 45) sugere que Filolau tenha mudado a teoria "tudo é número" para a teoria dos limitantes/ilimitados para responder exatamente à descoberta dos irracionais na geometria, que se daria imediatamente antes dele. ${ }^{112}$

A descoberta teria gerado um verdadeiro "melodrama na história intelectual grega” (Burkert 1972: 455), pois, na concepção pitagórica dos números à maneira das pedrinhas de Eurito, o fato de certas grandezas geométricas como a da diagonal do quadrado não poderem ser expressas por unidades numéricas era algo simplesmente escandaloso. Há, todavia, contra os argumentos de Knorr, uma séria dificuldade cronológica: no Fédon, Símias e Cebes afirmam ter ouvido Filolau em Tebas alguns anos antes. Por consequência, Filolau devia estar em plena maturidade intelectual no fim do século $\mathrm{V}$ a. $\mathrm{C}$, o que permite datar seu nascimento por volta de 460-70 e possivelmente devia estar ainda vivo em Tarento no início do século IV. Estas precisações cronológicas são fundamentais para determinar a relação entre Filolau e Hipócrates de Quios: Filolau não poderia ter escrito seu livro em reação ao problema da incomensurabilidade, pois os irracionais seriam descobertos por este último

especially their "crises," the points at which exacerbations or remissions are to be expected". Burkert (1972: 264) imagina, todavia, ao contrário, uma influência de Filolau - e mais em geral dos conceitos pitagóricos de harmonia e número, sobre o corpus hipocrático: "we perceive in the Hippocratic corpus reflections of Pythagorean doctrines, which were probably in written form; and the most likely source is the book of Philolaus".

${ }_{109}$ Os argumentos de Huffman (1993: 75) pelo qual Filolau, como faria um cientista moderno, esperaria por uma confirmação da teoria que deverá vir de futuras comprovações, como também de que sua busca não o obrigaria a indicar uma estrutura numérica "a qualquer custo", enfraquecem de fato a tese de Huffman e, por consequência, a ideia de que possa haver um programa de Filolau. Cf. neste sentido Huffman (1993: 77): "his project was nonetheless to find the numbers in things where he could and not to put them there at all costs".

${ }^{110}$ Orig.: "they would not enable us to solve our problems. For they reveal a thinker of no great stature, whose interests are peripherical”.

${ }^{111}$ Dediquei um recente artigo a esta questão (Cornelli e Coelho 2007a), para o qual remeto para maiores esclarecimentos em relação aos motivos e às consequências da referida crise.

${ }^{112} \mathrm{Cf}$. também, na mesma linha teórica, o acima citado Tannery (1887 b), em 1.7. 
somente em torno do ano de 430, quando Filolau - contemporâneo de Sócrates e Hipócrates - e não mais novo do que estes - havia alcançado já sua terceira idade.

Contudo, o argumento que mais interessa a esta monografia, conforme aparece na análise dos fragmentos acima, é que o problema da incomensurabilidade, no caso em que tivesse de alguma forma encontrado o pensamento de Filolau, não devia de forma alguma colocar em cheque o sistema de pensamento filolaico; notadamente, pelo fato de este não possuir propriamente uma teoria dos números como princípios da realidade - da forma que Aristóteles havia lhe atribuído. Ao contrário, conforme sugere Huffman (1988: 16), caso Filolau tivesse tido conhecimento da questão dos irracionais, poderia facilmente torná-lo mais um exemplo de sua tese de que todas as coisas são compostas por limitantes e ilimitados. Pois para além da história do melodrama acima citado, as descobertas da incomensurabilidade da hipotenusa do triângulo retângulo ou a irracionalidade da diagonal do quadrado devem ter aguçado o interesse, não exclusivo dos especialistas, por um fenômeno que combinava perfeitamente, na mesma figura, uma medida ilimitada, a da hipotenusa, com duas medidas perfeitamente limitadas, a dos catetos. ${ }^{113}$

Enfim, não deve importar se Filolau foi ao menos um matemático de destaque no interior do progresso que a disciplina obteve ao longo do século V aEC. Com razão, Burkert (1972: 413) anota que "o problema não é quem inventou a matemática, mas quem conectou matemática e filosofia” por primeiro. ${ }^{114}$ Esse foi sem dúvida Filolau (Huffman 993: 55). É nessa filosofia pitagórica do $\mathrm{V}$ século aEC que Aristóteles está quase que exclusivamente interessado.

O que é certo é que a relação entre Filolau e os números é a tal ponto significativa de merecer o resumo que Aristóteles teria dedicado aos assim chamados pitagóricos, e que, à luz do percurso aqui desenvolvido, pode-se certamente considerar como uma citação do próprio Filolau.

Exatamente porque "inocente das distinções posteriores entre sensível e inteligível, e que se tornam importantes mais tarde" (Huffman 1993: 52-53), ${ }^{115}$ isto é, como exceção ao sistema platonizante (Burkert, 1972: 230), a doutrina dos números de Filolau coincide em diversos lugares com o testemunho aristotélico.

${ }^{113}$ Cf. Huffman (1988: 16): "Viewed in this way, the case of the diagonal of the square (i.e. the isosceles right triangle) becomes an excellent illustration of Philolaus' central thesis about the cosmos. That thesis said that all things are com- posed of two unlike elements, limiters and unlimiteds, and that, since these elements are unlike each other, they must be held together by a harmonia which supervenes on them. In the case of the isosceles right triangle what must initially have caused wonderment was not only that the hypotenuse cannot be measured by any measure no matter how small but that such a magnitude without measure (an unlimited) is combined in the same figure with magnitudes that do have a measure, the sides (limiters)".

${ }^{114}$ Orig.: "the question is not who invented mathematics, but who connected mathematics with philosophy".

115 Orig.: "innocent of distinctions, such as that between the intelligible and the sensible, which become important later." 
Por consequência, pode ser considerada de fato a solução da atribuição ao pitagorismo antigo de uma doutrina do "tudo é número", conforme os sentidos epistemológico, ontológico e numerológico - acima detalhados -, que estas páginas estavam procurando.

O resto, e não é pouco, deve-se fundamentalmente à recepção platônica dessas teorias. 


\subsection{Conclusão}

Partindo da constatação de que a matemática é certamente um dos elementos mais recorrentes na tradição para a identificação da filosofia pitagórica, analisaram-se neste capítulo as tendências majoritárias da crítica contemporânea que submeteram a uma profunda revisão o testemunho aristotélico decisivo para esta categorização do pitagorismo: sua afirmação pela qual, para os pitagóricos, “tudo é número". A conclusão à qual chega essa postura hermenêutica cética de autores clássicos como Frank e Cherniss é a de que toda a matemática pitagórica seria na realidade resultado de uma transposição acadêmica.

Todavia, uma mais recente revisão dessas tendências da crítica, centrada na reavaliação da autenticidade dos fragmentos de Filolau, sugeriu um novo caminho hermenêutico, que aponte para a recuperação de uma efetiva teoria pitagórica dos números, que estaria presente nas fontes pré-socráticas.

A análise das diversas citações aristotélicas da doutrina "tudo é número" e de sua repetida atribuição aos pitagóricos revelou, para além de uma evidente variabilidade semântica da teoria, algumas contradições teoréticas que o próprio Aristóteles parece não conseguir resolver a partir daquelas que deviam ser suas fontes escritas. Três diferentes versões da doutrina estão, de fato, presentes na doxografia aristotélica: a) uma identificação dos números com os objetos sensíveis; b) uma identificação dos princípios dos números com os princípios das coisas que são; c) uma imitação dos números pelos objetos reais. Enquanto as versões a) e c) revelaram clara intenção polêmica de Aristóteles contra a militância platônica pela causa formal, a versão b), dos números como causas formais da realidade, demonstra ser uma reconstrução aristotélica da tese pitagórica. A esta reconstrução Aristóteles teria sido levado de um lado pela dificuldade de aceitar a noção pitagórica material de número, por outro lado, por considerá-la mais próxima à sua sensibilidade, fortemente marcada pela recepção dessa mesma teoria em âmbito acadêmico. De fato, a tradição platonizante, que faz aqui sua primeira aparição no capítulo, trata os números como princípios ontológicos. Depois de ter desempenhado um papel central na definição das teorias da imortalidade (3.4.4), a recepção acadêmica das doutrinas pitagóricas aparece aqui novamente também no âmbito da teoria dos números. O resumo aristotélico da teoria dos números revela-se, ao mesmo tempo, estar em dependência e em polêmica com o platonismo. Apesar de estar clara aquela que Aristóteles devia considerar a intuição fundamental dos pitagóricos, isto é, a possibilidade de compreender a natureza pelos números, o fato é que a tentativa de conciliação que Aristóteles estaria operando a partir das fontes pré-socráticas, de um lado, e da mediação platônica, do outro, não pareceu bem-sucedida.

Diante dessas dificuldades, duas soluções foram apresentadas mais recentemente para verificar o sentido e a validade da doutrina "tudo é número". De um lado, Zhmud, aprofundando uma já clássica posição de Burnet, contesta 
radicalmente a validade do testemunho aristotélico, chegando a negar que ao protopitagorismo corresponda uma doutrina do número como tal, perante o insucesso na busca de alguma referência a ela nas fontes pré-socráticas. A conclusão dessa tese negacionista é simplesmente que Aristóteles teria criado, para as finalidades internas à sua história doxográfica dos predecessores, um denominador comum doutrinário ("tudo é número") para uma escola filosófica que se lhe apresentava como pouco coesa do ponto de vista doutrinário, e que acaba por identificar com a categoria historiográfica dos "assim chamados pitagóricos". Em reação a essa solução, Huffman, retomando por sua vez uma intuição de Burkert, empreendeu um atento trabalho de reavaliação das fontes pré-socráticas do pitagorismo que deviam estar "na mesa" de Aristóteles, em busca de possíveis referenciais históricos para a reconstrução aristotélica. $\mathrm{O}$ fato de Aristóteles demonstrar atingir uma literatura pitagórica escrita, assim como os modos de utilização desta em sua própria produção literária sobre os pitagóricos, que foi certamente significativa, parece identificar como fonte primária de Aristóteles exatamente o livro de Filolau e, com este, o pitagorismo do $\mathrm{V}$ século a.C. Contudo, mesmo essa solução filolaica apresenta uma dificuldade: não há em Filolau alguma referência explícita a essa doutrina do "tudo é número".

Mais que solução, portanto, a "questão filolaica” apresenta-se, ao contrário, como uma gangorra hermenêutica entre a platonização acadêmica de um lado e a reconstrução aristotélica do outro. Tanto a inconsistência da tradição sobre a produção literária de Filolau como a existência de ampla literatura pseudoepigráfica helenística sugerem a necessidade de um atento trabalho de peneira dos fragmentos de Filolau em busca dos motivos mais autênticos de sua filosofia. Em última análise, as duas questões dependem de uma característica fundamental da literatura pitagórica pseudoepigráfica helenística, que é aquela de derivar sua compreensão da relação entre pitagorismo e platonismo de maneira cada vez diferente nos diversos momentos da história da polêmica intra-acadêmica entre dogmáticos e céticos. Por outro lado, no interior da reconstrução platônico-pitagorizante da filosofia dos "antigos", a descrição que Aristóteles, no século IV a.C, faz do pitagorismo não encontra eco algum. Ao contrário, o valor de seu testemunho é amplamente criticado em seguida pela tradição platônica. Porém, é exatamente esta distinção da lectio aristotélica em relação ao onipresente "sistema de derivação" da tradição platônica que constitui verdadeira alavanca hermenêutica para a questão filolaica, pois a proximidade dos fragmentos atribuídos a Filolau com a lectio aristotélica dos "assim chamados pitagóricos" pode tornar-se sinal de sua autenticidade.

Aristóteles de fato distingue pitagorismo e platonismo em duas questões centrais, ambas articuladas em uma célebre página de Metáfisica (987b). A primeira diferença está no lugar ontológico atribuído aos números: fora dos sensíveis para Platão, enquanto os pitagóricos sustentam que os números sejam "as próprias coisas". Trata-se da doutrina do chorismós, isto é, da separação, que Aristóteles considera um erro tipicamente platônico: a intenção polêmica de Aristóteles com o platonismo não poderia ser mais clara. A diferença indicada 
pelo testemunho aristotélico em relação à mediação acadêmica das doutrinas pitagóricas sugere que a primeira possa ser considerada um achado da visão pré-socrática dos números. Uma segunda diferença entre Platão e pitagóricos está na maneira como é concebido o um: o fato de Platão ter posto no lugar do um ilimitado pitagórico uma díade, como também de ter concebido o ilimitado como derivado do grande e do pequeno, resulta em uma doutrina "mal argumentada". Mesmo neste caso, Aristóteles está sozinho a definir essa diferença, pois a tradição doxográfica toda sublinha, ao contrário, que também os pitagóricos postulavam o um e díade indefinida como princípios da realidade, em clara dependência da derivação platonizante.

A análise de uma passagem do Filebo confirmou a credibilidade do testemunho de Aristóteles: a platonização do pitagorismo não devia corresponder somente a uma tendência acadêmica, mas já o próprio Platão devia considerar sua "segunda navegação" como uma continuação do pitagorismo. Contudo, se a página do Filebo revelou-se um testemunho pré-aristotélico da filosofia pitagórica, ela constitui ao mesmo tempo um ponto de partida para que Platão persiga seus próprios projetos teoréticos, de maneira especial em busca de uma solução para o problema da unidade e multiplicidade dos existentes.

O mesmo tema da relação ilimitado/limitado que orienta o argumento do Filebo aparece de fato naquele que devia ser o prólogo do livro de Filolau. O caráter de exceção dos testemunhos aristotélicos, diante da categorização majoritária platonizante do pitagorismo antigo, tornou central a análise dos fragmentos de Filolau. De um lado, por permitirem comprovar textualmente o processo de formação da recepção acadêmica da matemática pitagórica; por outro lado, por serem sinais inequívocos de uma teoria pitagórica dos números, datada ainda do século $\mathrm{V}$ a.C, que Aristóteles demonstra conhecer. Os fragmentos de Filolau revelam-se originalmente posicionados em relação à então secular tradição pré-socrática, operando quase uma síntese entre a cosmologia milesiana do ilimitado e a concepção da perfeição do ser no limite da matriz eleática. A autenticidade do fr. 2 é argumentada a partir do fato de não demonstrar alguma apropriação platonizante: limitantes e ilimitados são ainda pensados, não como princípios abstratos e separados do mundo, mas como atributos da própria realidade. Filolau, empreendendo uma tentativa de exemplificação da harmonía entre limitantes e ilimitados, utiliza significativamente a escala musical diatônica pitagórica. Porém, a possibilidade, revelada pelo fr. 6 de Filolau, de numerar os intervalos consoantes conduz novamente ao tema central deste capítulo, isto é, aquele do número pitagórico.

Ainda que não predominante como princípio ontológico - como queriam Platão e Aristóteles -, o número desempenha certamente uma função no interior do sistema filolaico. A análise dos fr. 4 e 5 parece indicar o fato de os números atuarem epistemologicamente, pois é exatamente pelo fato de prestar-se a uma descrição em termos numéricos que a realidade pode ser conhecida. Os números são, assim, sinais emitidos pela realidade, e como tais 
permitem que esta possa ser conhecida (fr. 5). Todavia, o mesmo fragmento sugere poder haver, em última análise, uma correspondência entre esses dois níveis, o ontológico (limitantes/ilimitados) e o epistemológico (par-ímpar). Pois a introdução de uma terceira espécie de número, o "parímpar", parece corresponder, na ordem argumentativa, à introdução da harmonía para a dupla limitantes/ilimitados. Huffman resiste todavia em considerar que os números no programa filosófico de Filolau possam desempenhar outro papel a não ser aquele de princípios explicativos da realidade, de maneira especial em polêmica com o evidente misticismo numérico, que, todavia, é também expresso nos fragmentos. Qualquer que seja este papel, contudo, a relação entre Filolau e os números mereceu o resumo que Aristóteles teria dedicado à categorização dos "assim chamados pitagóricos", e que coincide em diversos lugares com o livro de Filolau. Em suma, Filolau pode ser considerado a solução da atribuição ao pitagorismo antigo, mais precisamente do século $\mathrm{V}$ a.C, de uma doutrina do "tudo é número", que estas páginas estavam procurando.

Como no caso acima das teorias da imortalidade, portanto, é novamente Aristóteles a fornecer o testemunho mais confiável da existência de uma teoria numérica no pitagorismo antigo. Esse mesmo testemunho, quando espelhado em sua provável fonte filolaica, permite detectar o longo processo de apropriação platônica e acadêmica da matemática pitagórica.

A análise da tradição sobre a teoria dos números pitagórica, portanto, articulando os diversos níveis de uso dos números no pitagorismo antigo, do místico ao epistemológico, ao longo dos diferentes estratos da tradição, revelou mais uma vez o processo de formação da categoria pitagorismo em suas dimensões, sincrônica e diacrônica. Processo este que acaba revelando, ao mesmo tempo, significativas descontinuidades ao longo da tradição: abordagens inicialmente válidas, como aquelas de um provável misticismo numérico protopitagórico, são em seguida abandonadas, provavelmente por não dialogarem mais diretamente com o contexto mais geral da filosofia daquele segundo momento. Porém, são enfim retomadas com renovado entusiasmo em épocas posteriores, notadamente no período neoplatônico. Dessa forma, é possível que a matemática de Jâmblico pudesse ser mais próxima à mística dos números protopitagórica do que o eram os números de Filolau.

Contudo, a suposição de que possa haver clara divisão entre mística dos números e epistemologia, em todas as fases do pitagorismo, até mesmo na fase filolaica - como visto anteriormente -,é esta mesma resultado de preconceitos historiográficos. Depende, em última análise, de uma visão positivista da história do pensamento, desde suas origens, como um progresso contínuo em direção a uma não bem identificada ideia de racionalidade moderna, magistralmente representada por Galileu e Descartes, não acaso identificada com o raciocínio matemático. A descrição do pitagorismo antigo a partir destas precompreensões historiográficas, portanto, revela-se equivocada do ponto de vista de seu valor histórico. E acaba também perdendo aquela que é 
O pitagorismo como categoria historiográfica

provavelmente a característica mais extraordinária dele: a de um movimento de vida e pensamento que percorre séculos a fio da antiguidade conseguindo ser identificado como tal, apesar - ou melhor - por meio da polifonia de suas diferenças e contradições. 
Conclusão 
Nada melhor para concluir uma obra historiográfica sobre o pitagorismo que um detalhe editorial, aparentemente inócuo, mas que se revela significativo para a história da crítica do pitagorismo no século XX. Giangiulio introduz sua edição da literatura pitagórica pela editora Mondadori (Pitagora 2000: XVI) reproduzindo uma seção inteira da obra imprescindível de Burkert sobre o pitagorismo: Lore and Science in Ancient Pythagoreanism (1972: 208-217). Omite, todavia, significativamente, uma citação de Rohde que aparece em Burkert (1972: 217). ${ }^{1}$ A citação é a seguinte:

Cada idade tem seu próprio ideal de sabedoria; e houve um tempo quando o ideal do homem sábio, que, por seus próprios poderes inatos, conseguiu uma posição espiritual de destaque e discernimento, tornou-se presente nas pessoas de certos grandes homens que pareciam preencher as mais altas condições de sabedoria e poder que foram atribuídas ao vidente extático e ao sacerdote da purificação [...] nós não podemos chamá-los filósofos, nem sequer precursores da filosofia grega. Mais frequentemente seu ponto de vista foi aquele que o real impulso filosófico em direção à autodeterminação e à liberdade da alma havia consciente e decisivamente rejeitado, e continuou a rejeitar, embora, na verdade, não sem flutuações ocasionais e retrocessos. Assim, escreveu Erwin Rohde (Psyche II, 90), em referência a figuras como Epimênides e Abáris, sem incluir Pitágoras. Contudo, a mais antiga evidência indica que é precisamente nesta perspectiva que temos de ver Pitágoras. ${ }^{2}$

A omissão não é obviamente casual e obedece a uma disseminada dificuldade da crítica contemporânea para lidar com a perspectiva acima delineada por Rohde, na qual Burkert sugere que deva ser vista a figura de Pitágoras: isto é, aquela de uma história da filosofia que não se limite a repetir o script das diadochai de personagens e de conceitos formatados pela doxografia aristotélica, mas busque compreender a emergência do fenômeno no interior do contexto pragmático da sabedoria arcaica e de suas tipologias.

${ }^{1}$ Cf. Giangiulio (Pitagora 2000: XVI). A omissão não é injustificada do ponto de vista formal: o autor avisa (Pitagora 2000, V) sobre a ocorrência de "poche omissioni" na tradução da referida seção de Burkert.

${ }^{2}$ Orig.: "Every age has its own ideal of Wisdom; and there came a time when the ideal of the Wise Man, who by his own innate powers has achieved a commanding spiritual position and insight, became embodied in the persons of certain great men who seemed to fulfill the highest conceptions of wisdom and power that were attributed to the ecstatic seer and priest of purification (...) We cannot call them philosophers-not even the forerunners of Greek philosophy. More often their point of view was one which the real philosophic impulse toward self-determination and the freedom of the soul consciously and decisively rejected, and continued to reject, though not indeed without occasional wavering and backsliding'. So wrote Erwin Rohde (Psyche II, 90), in reference to figures like Epimenides and Abaris, without including Pythagoras. But the most ancient evidence indicates that it is precisely in this perspective that we must see Pythagoras”. As reticências no interior da citação são do próprio autor. 
A ilusão criada pela coleção dielsiana dos textos sobre a filosofia pré-socrática sugeriu que a sucessão dos sistemas filosóficos ao longo da história pudesse significar - hegelianamente - algum tipo de progresso do pensamento. Todavia, o desvelamento dessa ilusão retrospectiva em relação à existência de uma escola filosófica pitagórica, ao lado e em diálogo com outras, não levou ainda grande parte da crítica a rever esta perspectiva historiográfica e a compreender a filosofia pré-socrática em geral e o pitagorismo de maneira especial, por meio das características próprias dos primeiros passos, permeáveis e fluidos, da filosofia em formação. A proposta de Laks (2007: 233-235), de certa maneira conciliadora, é de compreender a heterogeneidade com a qual a filosofia pré-socrática se apresenta como "uma diversidade não selvagem, e sim reflexiva", no sentido de obedecer, weberianamente, a dois tipos de "consistências": uma lógica, pela qual uma nova tese implica a resposta ou a explicitação de uma teoria anterior; e uma prática, que mobiliza mais diretamente a questão do sujeito, no caso específico do autor de determinada filosofia. As páginas da presente obra quiseram revelar franca inserção das ideias e dos protagonistas do protopitagorismo e do pitagorismo do século $\mathrm{V}$ no contexto da disciplina filosófica em formação. Contudo, a percepção de que haveria uma segunda consistência, ao lado da imagem anacrônica dos pré-socráticos como scholars e colleges em debate entre eles, como a consistência lógica parece sugerir, é certamente o avanço hermenêutico mais relevante. ${ }^{3}$

$\mathrm{Na}$ verdade, há algo de heterogêneo no pitagorismo que é, no limite, irredutível a esta lógica disciplinar. Ainda que, com razão, Laks (2007: 230) afirme que "é um lugar hoje bastante comum afirmar que a filosofia, como disciplina, não existe antes de Platão", não é possível simplesmente esquecer que a tradição considera Pitágoras como o inventor dos termos filosofia e filósofo (D. L. Vitae I. 12 = Heraclid. fr. 87 Wehrli). ${ }^{4}$ No entanto, a filosofia conforme o viés da tradição pitagórica parece definir-se bem, como disciplina, também pela segunda consistência, aquela prática; isto é, de estilos de vida, doutrinas reveladas e ouvidas, ritualidades éticas e sapienciais.

O "buraco sem fundo" (the bottomless pit) da pesquisa sobre os pitagóricos - na célebre expressão de Guthrie (1962: 146 n1) - revelou-se um locus privilegiado para a revisão das práticas historiográficas comumente utilizadas. Dessa forma, a dificuldade de fazer caber a filosofia pitagórica, "trait d'union", entre as primeiras duas fases da filosofia antiga, isto é, a jônica e a itálica, nos estreitos limites da historiografia normal, ficou patente e obrigou a presente obra a rediscutir os procedimentos metodológicos de aproximação ao

\footnotetext{
${ }^{3}$ Apesar de enunciá-la, todavia, Laks não desenvolve - como faz com a consistência lógica esta segunda. A omissão é ainda um sintoma da dificuldade da historiografia da filosofia antiga em enfrentar seu objeto fora dos esquemas "presentistas" da tradição (cf. Laks 2007: 233).

${ }^{4}$ Burkert (1960) criticou por primeiro a confiabilidade do testemunho, que remonta a Heraclides Pôntico. Também cético é Huffman (2008: 205-206). Mais confiante na tradição está Riedweg (2002, 156-164). Centrone (1996,93-98), apesar de cético, considera que, mesmo assim, possa-se qualificar Pitágoras como filósofo.
} 
seu objeto. Na melhor tradição científica moderna, foi obrigada a reconstruí-lo, de certa maneira, para poder examiná-lo.

Em suma, a história da tradição do pitagorismo é uma história de omissões.

A omissão editorial de Giangiulio é o exemplo mais recente de um processo secular de recepção, pelo qual, como em um palimpsesto, formas e conteúdos desta filosofia foram apagados e reescritos a partir de sempre novos interesses redacionais (Riedweg 2002: 201). O resultado disso, do ponto de vista da teoria das fontes, assustou com razão muitos comentadores, desde a antiguidade: uma multiplicidade poliédrica de imagens do pitagorismo, que o representam ora como seita religiosa, ora como escola filosófica, ora ainda como partido político ou como comunidade científica. E não é certamente suficiente, como boa prática científica, uma genérica "confiança fundamentada nos testemunhos", conforme o desejo sinceramente expresso por Boyancé em seu discurso in memoriam de Ferrero (1966: 31). De fato, muitos estudiosos, no meio do mato sem cachorro da Quellenforschung do pitagorismo, como que em desespero, acabaram por "entregar-se a um método intuitivo e a formular hipóteses baseadas na simples verossimilhança" (Centrone 1996: 23), ${ }^{5}$ aumentando assim a confusão, à qual já se referia Boeckh (1819), no lugar de diminuí-la.

A proposta dessas páginas, ao contrário, foi aquela de procurar definir um percurso metodológico consciente, que, em vez de tentar resolver a complexidade do fenômeno optando por uma ou outra imagem, propôs-se a compreender o pitagorismo como categoria historiográfica. Seguindo a metáfora, anteriormente desenhada, do palimpsesto, a tese destas páginas é que a solução não deve ser procurada principalmente em um pretenso pergaminho original, e sim, mais apropriadamente, no próprio processo de contínua sobrescrita deste. À procura de compreender a lógica de suas omissões, traduções, reapropriações ao longo da história. Interpretando interpretações.

Longe de considerar, portanto, a imagem multifacetada do pitagorismo como simplesmente resultado de uma série de acidentes, procurou-se acompanhar o percurso das escolhas que constituíram a tradição, verificando, quando possível, seus pressupostos, e indicando as consequências destas para a interpretação. Receberam este tratamento não somente algumas temáticas centrais, como a metempsicose e a teoria dos números, mas também o próprio percurso de definição do pitagorismo como categoria.

Não se tratou, contudo, de escolher entre um pitagorismo acusmático, de um lado, e outro matemático, do outro - como parte da história da crítica moderna quis fazer, conforme foi visto no capítulo primeiro. Ainda que os inícios da koinonía pitagórica devessem de fato ser acusmáticos, o fato não explica sozinho o amplo leque das tradições sobre o pitagorismo, mesmo em época présocrática. Em uma primeira impressão, a abordagem em capítulos separados das duas temáticas que mais fortemente estão presentes na tradição da filosofia pitagórica, a metempsicose (capitulo terceiro) e a teoria dos números (capítulo

${ }^{5}$ Orig.: "ad affidarsi a un metodo intuitivo e a formulare ipotesi basate sulla semplice verosimiglianza”. 
quarto), pode parecer reproduzir hermeneuticamente a distinção clássica entre bios e theoría. O primeiro diria respeito a mitos e ritos da imortalidade da alma; a segunda referir-se-ia à ciência dos números. Todavia, não é certamente este o caso. Ao contrário, a análise acima desenvolvida demonstrou que em ambas as temáticas tão caras à tradição sobre o pitagorismo aparecem lectiones tanto místicas como científicas, pois, por um lado, a teoria da metempsicose não responde somente a uma mística soteriológica, mas se torna também elemento explicativo da realidade em sua conaturalidade, além de motivo epistemológico na prática da anamnese. Por outro lado, a teoria dos números não corresponde somente a uma reflexão aritmogeométrica, ontológica e cosmológica, mas também serve a uma mística numerológica amplamente atestada pela tradição.

Isso posto, se Filolau possui uma teoria da alma como harmonia de elementos materiais, ao lado de uma teoria da imortalidade da alma; e da mesma forma utiliza os números não somente como princípios epistemológicos de seu sistema ontológico, mas também revela seu sentido numerológico; é certamente o caso de se perguntar se a distinção entre mística e ciência, aqui mostrada, faz algum sentido para descrever o pitagorismo antigo e a filosofia em suas origens como tal. Os capítulos terceiro e quarto, articulando as duas dimensões da categorização do pitagorismo, diacrônica e sincrônica, permitiram confirmar a suspeita citada. Em sua dimensão sincrônica, a categorização do pitagorismo demonstrou obedecer à intenção de separar dicotomicamente mística e ciência; enquanto, em sua dimensão diacrônica, os processos de omissão e redução da multiplicidade em que se apresentam as doutrinas pitagóricas revelaram-se operantes na recepção acadêmica, peripatética, neoplatônica etc.

No entanto, em sua dimensão diacrônica, a categoria historiográfica do pitagorismo resistiu a diferentes tentativas de reduzi-la a um lado ou a outro da dicotomia bios-theoría. Essas tentativas não operam exclusivamente no que se refere à distinção acusmáticos vs. matemáticos no protopitagorismo, mas continuam presentes na história do movimento mesmo após a mediação da tradição acadêmica e sua vulgata pitagórica. Em época imperial, há de fato um abismo entre o "matemático" Moderato di Gades e o "acusmático" Apolônio de Tiana. Todavia, ambos são igualmente identificados como pitagóricos. E não é o caso de explicar esta homología por uma simples referência a um ideal de vida pitagórico, pois esse ideal deveria necessariamente incluir um conjunto de doutrinas que o identificava, ainda que este conjunto não chegue jamais a constituir um cânon e permaneça convenientemente a referência ao segredo e à oralidade como estratégia de garantia das diferentes leituras. ${ }^{6}$

A essa problemática pertence a polêmica sobre o fim do pitagorismo em época helenística. A questão mereceria sozinha uma nova monografia. É aqui lembrada simplesmente como ilustração das tentativas de inserir uma lógica evolutiva na história do pitagorismo, à qual, todavia, a tradição parcialmente resiste. É comum entre os comentadores atuais, na esteira de Burkert (1961: 232), postular um reflorecer do pitagorismo nos últimos anos do primeiro

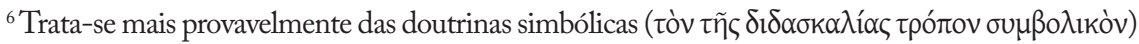
- na terminologia usada por Jâmblico (VP:20) - representadas pela memória dos acusmata.
} 
século a.C, depois de sua extinção, que teria ocorrido em 360 a.C, ano em que Aristóxeno declara ter conhecido o último pitagórico (fr. $14 \mathrm{Wehrli)}$ ). O renascimento do pitagorismo é testemunhado por Cícero, em sua introdução à tradução do Timeu: seu amigo Nigídio Fígulo teria feito reviver (renovaret) o pitagorismo (Cicero. Timaeus 1.1). As duas fases do pitagorismo não estariam somente separadas no tempo, pois, segundo o próprio Burkert (1982), os dois movimentos seriam bastante heterogêneos. ${ }^{7}$

Entretanto, o postulado da ruptura entre o pitagorismo antigo e o neopitagorismo incorre em algumas dificuldades. Primeiramente, para se sustentar, precisa esquecer a continuidade, ao menos literária e cultural, representada pela literatura pseudoepigráfica helenística, que preenche o pretenso "gap" de três séculos que a ruptura criara. Além de não estar claro qual seja o valor histórico a ser concedido aos testemunhos acima de Aristóxeno e Cícero. ${ }^{8}$

Por outro lado, as vantagens dessa separação para certa historiografia do pitagorismo são incomparáveis. Notadamente por permitirem empurrar para uma época tardia aquelas características acusmáticas da filosofia pitagórica que deviam parecer destoantes com a imagem canonizada do iluminismo jônico e da filosofia itálica antigos. É certamente o caso de Dodds, quando afirma que:

Muitos estudiosos do tema viram no século I a.C o período decisivo de Weltwende, período no qual a maré do racionalismo, que nos cem anos anteriores se havia desenvolvido como nunca, finalmente havia esgotado seu impulso e começado a recuar. Não resta dúvida de que todas as escolas filosóficas, exceto a epicurista, tomaram neste momento um novo caminho. [...] Da mesma forma, é significativo o renascimento do pitagorismo, após dois séculos de aparente esquecimento, não como escola doutrinária formal, mas como culto e como estilo de vida. Confiava abertamente na autoridade, não na lógica: Pitágoras era apresentado como um sábio inspirado (Dodds 1951: 247).

Contudo, essas mesmas características que Dodds atribui ao neopitagorismo, a de constituir-se como bios em oposição à doutrina de uma escola, de cultivar o princípio da autoridade, e mesmo de apresentar Pitágoras como um homem divino, todas poderiam valer já para o protopitagorismo.

O preconceito historiográfico que desenha o caminho desta hermenêutica da separação é aquele do esgotamento, em época tardia, do impulso racional da filosofía clássica. É possível encontrá-lo mesmo em um autor como Festugière, frequentador assíduo da literatura mística antiga. Seu juízo sobre o neopitagorismo, que não esconde um sentimento de escândalo e o repúdio pessoal do comentador, é aquele de uma perversão ou uma degradação da pura ciência teorética clássica, em consequência do relaxamento das morais contemporâneas (Festugière 1932: 74-77).

${ }^{7}$ Cf. Contrários à ruptura defendida por Burkert, tanto Dörrie $(1963,269)$ quanto Kingsley (1995: 320ss.).

${ }^{8}$ Cf. para isso os argumentos de Kingsley (1955: 323-324). 
Contra a ideia dessa ruptura, portanto, para além dos argumentos que tendem a considerá-la bastante duvidosa do ponto de vista histórico, pesa também a observação da origem protopitagórica de práticas e doutrinas que a crítica quis empurrar para o pitagorismo tardio por representarem um incômodo hermenêutico na busca da pura filosofia em suas origens. A continuidade, portanto, é maior do que se quis geralmente admitir. Desde o início da tradição pitagórica, bios e theoría continuam fundamentalmente inseparáveis.

A imagem que resulta da análise da categoria do pitagorismo ao longo da história da tradição é a de uma grande tradição filosófica homogênea que pretende compreender o ser humano, o céu, a história, a política, mediante conceitos como harmonia, número, justiça etc. E, todavia, porquanto esta imagem do pitagorismo possa parecer fascinante e tenha conquistado adeptos ao longo de toda história do Ocidente, é ela mesma resultado de uma categorização, que, por sua vez, obedece aos interesses de quem conta a história desta forma. A vulgata platônica à qual teriam sido reconduzidas as diversas tradições pitagóricas anteriores constitui o eixo historiográfico fundamental dessa reconstrução, como os exemplos das teorias da imortalidade da alma e da doutrina dos números bem demonstraram. A recepção neoplatônica, de maneira especial, recobre um papel central nesse sentido, graças à sistematização do pitagorismo em suas Vidas.

Mesmo que tenha se demonstrado árduo identificar quanto do pitagorismo antigo haveria sobrado de fato nessa recepção acadêmica, não é possível negar que a vulgata platônica tenha contribuído positivamente para imortalizar o pitagorismo como "a filosofia" por antonomásia, permitindo que o conjunto de estilos e doutrinas "assim chamadas pitagóricas" conquistasse a simpatia, quando não mesmo uma adesão incondicional, de tantas e diversas personagens ao longo da história, desde os renascentistas Marsilio Ficino e Pico della Mirandola até os precursores da ciência moderna, Copérnico, Kepler e Galileu. ${ }^{9}$

Frequentemente o sucesso histórico do pitagorismo é utilizado para justificar retroativamente o valor de uma tradição que em si mesma encontrase irremediavelmente contaminada por elementos suspeitos e inaceitáveis ao olhar do cientista moderno. Com um alívio mal escondido, parte da crítica contemporânea reconhece que, apesar de tudo, sua influência na ciência moderna fornece à conturbada história do pitagorismo um "final feliz" ( $h a p p y$ ending - Kahn 2001: X). ${ }^{10}$

${ }^{9}$ Copérnico reconhece explicitamente a influência pitagórica sobre a tese da mobilidade da terra no Prefácio de seu De revolutionibus: Pythagoreorum E̋ quorundam aliorum sequi exemplum. Nesta tese, refere-se ao Edito da Sagrada Congregação do Índice (datado 5 de março de 1616) citado por Galileu no início de seu Dialogo sopra $i$ due massimi sistemi del mondo tolemaico e copernicano: "Si promulgò a gli anni passati in Roma un salutifero editto, che, per ovviare a' pericolosi scandoli dell'età presente, imponeva opportuno silenzio all'opinione Pittagorica della mobilità della Terra". De sua parte, Kepler é chamado de "Pitágoras redivivus" por Riedweg (2002: 206), por procurar demonstrar a fundamental harmonia do mundo em perspectiva cristãpitagórica e por se considerar, intelectualmente, a própria reencarnação de Pitágoras.

${ }_{10}$ Assim, Kahn (2001: X): "[Pythagorean] tradition includes so many elements of wild, 
Entretanto, não é algo dado que a história do pitagorismo precise desse final feliz científico. Ao contrário, as páginas da presente obra pretenderam mostrar que esta metodologia de coleta seletiva no interior das tradições sobre o pitagorismo é historicamente incorreta e filosoficamente vã. Burkert, por sua vez, apontava para isso em relação à compreensão da própria figura de Pitágoras, cujos problemas de equivocidade espelham-se ao longo de toda a categoria historiográfica do pitagorismo:

Pareceu muitas vezes suficiente um "não somente-mas também": ele não era somente um curandeiro, mas também um pensador. Contudo, não será talvez que até um "xamã" possa realizar conquistas intelectuais, sem necessariamente revesti-las em uma forma estritamente racional ou conceitual? (Burkert 1972: 209). ${ }^{11}$

Mais uma vez, portanto, é a consciência da equivocidade de categorias como filosofia, religião e ciência - frequentemente usadas em sua acepção mais positivista na descrição do que seria filosofia em suas origens - que permitiu mostrar a necessidade metodológica de superar uma visão excessivamente presentista da filosofia antiga, que procura reduzir o passado a uma prova geral do presente.

Ainda que desse percurso historiográfico resulte uma imagem um tanto difusa do pitagorismo, ela deve ser preferida às várias tentativas demasiadamente claras e distintas de fechar sua multifacetada complexidade nos moldes estreitos de uma categorização irremediavelmente insuficiente. Ecoam aqui as palavras de Wittgenstein, relacionadas por ele ao conceito de jogo de linguagem:

Poderia-se dizer que o conceito de "jogo" é um conceito de contornos nebulosos. 'Mas um conceito nebuloso é de fato um conceito?' - Uma foto pouco nítida é ainda um retrato de alguém? Será que é sempre vantajoso trocar um retrato pouco claro por outro nítido? Não é exatamente daquele pouco nítido que muitas vezes precisamos? (Wittgenstein 1958: 71). ${ }^{12}$

A presente obra é, assim, o resultado de uma escolha consciente, anunciada na Introdução, de evitar propor simplesmente mais uma interpretação do pitagorismo; essas páginas, ao contrário, procuraram enfrentar a própria questão historiográfica que subjaz às diversas opções hermenêuticas de solução da "questão pitagórica", e que, de certa forma, reinventam-na continuamente.

almos superstitious speculation, for example, in numerology, that it is sometimes difficult to remember that there is also a solid basis for numerical harmonics. So Copernicus and Kepler, with their fundamental contributions to modern science and to the modern world view, may be regarded as providing the Pythagorean story with a happy ending”.

${ }^{11}$ Orig.: "Often a simple 'not only-but also' has seemed enough; he was not only a 'medicine man' but also a thinker. But may not even a 'shaman' perhaps accomplish intellectual feats, without necessarily clothing them in strictly rational or conceptual form?".

12 Orig.: "One might say that the concept "game" is a concept with blurred edges. "But is a blurred concept a concept at all?' - Is an indistinct photograph a picture of a person at all? Is it even always an advantage to replace an indistinct picture by a sharp one? Isn't the indistinct one often exactly what we need?". 
Um estudo sobre o pitagorismo "arrisca ser ou inútil ou insuficiente, tamanha é a quantidade de literatura, tão complexo é o problema”, já anotava lucidamente Maria Timpanaro Cardini (1958: I, 3). ${ }^{13}$ Se também estas páginas fossem obrigadas a escolher entre esses dois destinos, prefeririam certamente crer terem escapado do primeiro, ainda que caindo inevitavelmente no segundo.

${ }^{13}$ Orig.: "rischia di essere o inutile o insufficiente: tanta è la mole della letteratura, tanto complesso è il problema”. 


\section{BibLIOgRAFIA}

\section{Fontes primárias}

Aelian. Historical Miscellany, Transl. Nigel G. Wilson. Harvard University Press, Harvard, 1997.

Agostino. Le ritrattazioni. Introduzione generale di G. Madec; traduzione, annotazioni e sommario di U. Pizzani U. Città nuova, Roma, 1994.

Agostino. Contro gli accademici. Introduzione, traduzione, note e apparati di G. Catapano. Bompiani, Milano, 2005.

Alessandro di Afrodisia e Pseudo-Alessandro. Commentario alla "Metafisica" di Aristotele. A cura di Giancarlo Movia. Bompiani, Milano, 2007.

Ambrogio. Commenti ai Salmi. In Migne, J. P. Patrologia Latina 6, col. 405-9. Garnier Frères, Paris, 1878.

Aristotele. Tre Etiche. Trad. Arianna Fermani. Bompiani, Milano, 2008.

Aristoteles. Aristotelis qui ferebant librorum fragmenta. Collegit V. Rose, Lipsiae, Teubner, 1886.

Aristóteles. Metafísica. Ensaio introdutório, texto grego com tradução e comentário de Giovanni Reale, trad. Marcelo Perine. Loyola, São Paulo, 2002.

Aristóteles. De Anima. Apresentação, tradução e notas de Maria Cecília Gomes dos Reis. São Paulo, Ed. 34, 2006.

Aristotle. De sensu and De memoria. Text and translation, with introduction and commentary, by G. R. T. Ross. Cambridge University Press, Cambridge, 1906.

Aristotle. Politics. Transl.H. Rackham (Loeb Classical Library). Cambridge: Harvard U. Press, 1932.

Clemens Alexandrinus. Stromata. Herausgegeben von Otto Stählin (1906), Buch I-VI, 4te Auflage; neue herausgegeben von Ludwig Früchtel, Ursula Treu [Die griechischen christlichen Schriftsteller, 52 (15)]. Akademie Verlag, Berlin, 1985.

Copernico, Nicolaus. De Revolutionibus Orbium Coelestium. Ioh. Petreium, Norimbergae, 1543.

Cusano, Nicola. Opere. A cura di G. Federici Vescovini. UTET, Torino, 1972. Damascius. Traité des premiers príncipes. Texte établi par L.-G. Westerink et 
traduit par J. Combès, 3 vols. Les Belles Lettres, Paris, 1986-1991.

Derveni Papyrus, The. Edited with Introduction and Commentary by Theokritos Kouremenos, George M. Parássoglou. Kyriakos Tsantsanoglou (Studi e testi per il "Corpus dei papiri filosofici greci e latini", 13). Leo. S. Olschki, Florence, 2006.

Diels, H. A. Doxographi Graeci. Weidmann, Berlin, 1879.

Diels, H. A. e Kranz, W. Die Fragmente der Vorsokratiker. 6a ed., Berlin, Weidmann, 1951 (Primeira edição: Diels, H A. Die Fragmente der Vorsokratiker. Weidmann, Berlin, 1906).

Dindorf, W. Scholia Graeca in Homeri Odysseam. 2 vols., Oxford University Press, Oxford, 1855. (repr. A. M. Hakkert, Amsterdam, 1962).

Diogene Laerzio. Vite e dottrine dei più celebri fllosofi. A cura di G. Reale. Bompiani, Milano, 2005.

Elmsley , P. Scholia in Sophoclem. Clarendon Press, Oxford, 1825.

Erodoto. Storie. Testo greco a fronte. Introduzione di Filippo Càssola; traduzione di Augusta Izzo D'Accinni; premessa al testo e note di Daniela Fausti (1984), 4 vols. (1: Libri I-II; 2: Libri III-IV; 3: Libri V-VII; 4: Libri VIII-IX). Biblioteca Universale Rizzoli (BUR), Milano, 1997.

Eschilo. Tutti iframmenti con la prima traduzione degli scolii antichi. Bompiani, Milano, 2009.

Euripides. Evripidis Tragoediae (vols. 1 \& 2; vol. 3 Tragödiae Superstites et Deperditarum Fragmenta), Ex Recensione [Joh.] Aug. Nauck. B. G. Teubner, Lipsiae, 1854 (vols. 1 \& 2; 3 ed., 1871); 1869 (vol. 3; 2 ed. 1871).

Eusebius of Caesarea. Preparation for the Gospel, translated by Edwin Hamilton Gifford. 2 vols. Clarendon Press, Oxford, 1903.

Ficinus, M. (1576). Opera omnia, 2 vols. Basel (Riproduzione in fototypia a cura di M. Sancipriano, con presentazione di P. O. Kristeller. Bottega d'Erasmo, Torino, 1959, 1962, 1983).

Galileo Galilei. Dialogo sopra i due massimi sistemi del mondo tolemaico e copernicano, 1632 (ed. moderna: Einaudi, Torino, 1970).

Giamblico. La vita pitagorica. A cura di L. Monteneri. Laterza, Roma/Bari, 1994.

Giamblico. Summa Pitagorica. Introduzione, traduzione, note e apparati di Francesco Romano. Bompiani, Milano, 2006.

Giuseppe, Flavio. La guerra giudaica. Trad. e note G. Vittucci, 2 vols. Arnaldo Mondadori, Milano, 1974. 
Greene, W. C. Scholia Platonica (scholia vetera). American Philological Association, Haverford (Pennsylvania), 1938.

Hermann, G. (ed.) (1805). Orphica, cum notis H. Stephani, A. Chr. Eschenbachii, I. M. Gesneri, Th. Tyrwhitti. Caspar Fristsch, Lipsiae (nachdruck Georg Olms, Hildesheim, 1971).

Hesíodo. Os trabalhos e os dias. Tradução de Mary de Camargo Neves Lafer. Iluminuras, São Paulo, 1989.

Iamblichus. De vita Pythagorica liber; accedit epimetrum De Pythagorae Aureo carmine. Ed. [J.] A. Nauck. St. Petersburg, 1884 (repr. A. M. Hakkert, Amsterdam, 1965).

Iamblichus. Iamblichi. De vita Pythagorica Liber, ed. Ludwig Deubner. Teubner, Leipzig, 1937.

Jamblique. Vie de Pythagore. Introduction, traduction et notes par Luc Brisson et A. Ph. Segonds. Les Belles Lettres, Paris, 1966.

IoAnnis Stobaei. Florilegium, ed. Thomas Gaisford. Ex typographeo Clarendoniano, Oxford, 1822-1855.

Isócrates. Discursos. Trad.J. M. Guzmán Hermida, 2 vols. (Biblioteca Clásica Gredos, 23). Editorial Gredos, Madrid, 1979-80.

Jacoвy, F. Die Fragmente der Griechischen Historiker, Berlin 1923-1958, cont. G. Schepens. Koninklijke Brill NV, Leiden/Boston/Köln, 1998-1999.

Kern, O. Orphicorum fragmenta. Weidmann, Berlin, 1922.

Lactantius. De vita beata. In Migne,J.P. Patrologia Latina 6, col.777, Garnier Frères, Paris, 1878a.

Lactantius. Divinarum Institutionum. In Migne, J. P. Patrologia Latina 6, col. 405-9, Garnier Frères, Paris, 1878b.

Liddell, H. G. e Scott, R. Greek-English Lexicon. IX Edition with a Revised Supplement. Clarendon Press Oxford, 1996.

Luciano di Samosata, Tutti gli scritti, traduzione di Luigi Settembrini. Bompiani, Milano, 2007.

Numénius. Fragments. Ed. É. des Places. Les Belles Lettres, Paris, 1974.

Olympiodorus. The Greek Commentaries on Plato's Phaedo. 1 vol., Transl. L. G. Westerink. Royal Netherlands Academy of Arts \& Sciences, Amsterdam, 1976.

Ovid. Metamorphoses. Translated by Brookes More. Boston, Cornhill Publishing Co. 1922.

Petrarca, F. Canzoniere, Trionfi, Rime varie. A cura di Carlo Muscetta e Daniele Ponchiroli. Einaudi, Milano, 1958. 
Philo. Philonis Alexandrini opera quae supersunt, ed. L. Cohn, P. Wendland, S. Reiter, 6 vols. Georg Reimer, Berlin, 1915 (nachdruck De Gruyter, 1962).

Philo. [Works of Philo] Vol. IX (Every Good Man Is Free; The Contemplative Life; The Eternity of the World; Against Flaccus; Apology for the Jews; On Providence). Transl. F. H. Colson. Loeb Classical Library. Harvard University Press, Cambridge/London , 1941.

Philostratus. The Life of Apollonius of Tyana. Trad. de F. C. Conybeare. Harvard University Press, Cambridge/London, 1948-50.

Photius. Bibliothèque. Ed. R. Henry, 8 vols. (1: 1959; 2: 1960; 3: 1962; 4: 1965; 5: 1967; 6: 1971; 7: 1974; 8: 1977). Les Belles Lettres, Paris, 1959-1977.

Picus Mirandullanus, J. F. [Pico della Mirandola, G.] (1572). Opera quae extant omnia. Basel (Riproduzione in fototypia $=$ vol. 1 dell'Opera omnia, 2 vols., con una premessa di Eugenio Garin. Bottega d'Erasmo, Torino, 1971).

Pitagora. Le opere e le testimonianze. A cura di M. Giangiulio, 2 vols. Mondadori, Milano, 2000.

Pitagorici. Testimonianze e Frammenti. A cura di M. Timpanaro Cardini, 3 vols. La Nuova Italia, Firenze, 1958-62.

Plato. Meno. Edited with Introduction and Commentary by R. S. Bluck. Cambridge University Press, Cambridge, 1964.

Plato. Philebus. Translated with Introduction and Commentary by R. Hackfort, London/New York, 1958.

Plato. Philebus. Translated by R. A. H. Waterfield with Introduction, Penguin, Harmondsworth, 1982.

Platone. Tutti gli scritti. A cura di Giovanni Reale. Rusconi, Milano, 1991.

Platone. Opere Complete. Edizione elettronica a cura di G. Iannotta, A. Manchi, D. Papitto. Indice dei nomi e degli argomenti a cura di Gabriele Giannantoni. Laterza, Roma, 1999.

Platone. Filebo. Introduzione, traduzione e note a cura di Maurizio Migliori. Bompiani, Milano, 2000.

Platone. La Repubblica. Testo greco a fronte, curato da M. Vegetti. Biblioteca Universale Rizzoli (BUR), Milano, 2007.

Platone. Lettere. A cura di Margherita Isnardi Parente. Trad. di Maria Grazia Ciani. Fondazione Lorenzo Valla/Arnoldo Mondadori Editore, Milano, 2002.

Plutarch. Lives. Trans. B. Perrin, 11 vols. Harvard University Press, Cambridge, 1914-1926. 
Plutarch. Simposiacs (Quaestiones Convivales). The complete works of Plutarch: essays and miscellanies, ed. Thomas Y. Crowell, vol. III. T. Crowell \& Co., New York, 1909.

Porfirio. Astinenza dagli animali. A cura di G. Girgenti e A. R. Sodan. Bompiani, Milano, 2005.

Por Phyrius. Porphyrii philosophi Platonici Opuscula selecta, ed. [J.] A. Nauck. Teubner, Leipzig, 1886.

Senocrate-Ermodoro. Frammenti. Edizione, traduzione e commento di M. Isnardi Parente. Bibliopolis, Napoli, 1982.

Siculus, Diodorus. Library of History, vol. IV, Books IX-1XII.40. Transl. C. H. Oldfather (Loeb Classical Library, 375). Harvard University Press, Cambridge, 1935.

Sophocles. The Electra of Sophocles. Edited with introduction and notes by Sir Richard Jebb. Cambridge University Press, Cambridge, 1894.

Speusippo. Frammenti. Edizione, traduzione e commento a cura di M. Isnardi Parente. Istituto Italiano per gli Studi Filosofici, Napoli, 1980.

Speusippus of Athens. A Critical Study. Collection of the Related Texts and Commentary by L. Tarán (Philosophia Antiqua, 39.). Brill, Leiden, 1981.

Tertullianus. De Anima, in Migne, J. P. Patrologia Latina 2, col. 697-701, Garnier Frères, Paris, 1878.

Thesleff, H. The Pythagorean Texts of the Hellenistic Period, Acta Academiae Aboensis, Åbo, 1965.

Timaeus Locrus. De Natura Mundi et Animae. Überlieferung, Testimonia, Text und Übersetzung von Walter Marg (Philosophia Antiqua, 24). E. J. Brill, Leiden, 1972.

Titus Livius. Ab Urbe condita; recognovervnt et adnotatione critica instrvxervnt Robertvs Seymour Conway et Carolvs Flamstead Walters, 5 vols. Ex Typographeo Clarendoniano, Oxford, 1914-1965.

Wehrli, F. Die Schule des Aristoteles; Texte und Kommentar (1944-1960), Heft I: Dikaiarchos (1944), Heft II: Aristoxenos (1945), Heft III: Klearchos (1948), Heft VII: Herakleides Pontikos (1953); Heft VIII: Eudemos von Rhodos (1955). Benno Schwabe, Basel, 1944-1955; 2te ergänzte und verbesserte Aufl. 1967.

Zosime de Panopolis (1995). Les alchimistes grecs, Vol.IV,1: Zosime de Panopolis, Mémoires authentiques. Trad. M. Mertens. Les Belles-Lettres, Paris. 


\section{Fontes secundárias}

Accame, S. (1980).'Pitagora e la fondazione di Dicearchia'. Settima Miscellanea Greca e Romana. Istituto Italiano per la Storia Antica, Roma: 3-44.

Achtemeier, P. J. (1972). 'The Origin and Function of the Pre-marcan Miracle Catenae'. Journal of Biblical Literature, 91 (2): 198-221.

Alesse, F. (2000). 'La dottrina pitagorica della metempsicosi nel De Anima di Aristotele'. In Tortorelli Ghidini, M.; Marino, A. S. e Visconti, A. Tra Orfeo e Pitagora: origini e incontri di culture nell'antichità. Atti dei seminari napoletani 1996-98. Bibliopolis, Napoli: 397-412.

Alderink, L. J. (1981). Creation and salvation in ancient Orphism. Scholars Press, Chico/California.

Alfieri, V. E. (1953). Atomos Idea: l'origine del concetto dell atomo nel pensiero greco. Le Monnier, Firenze.

Balaudé, J.-F. (2002). Le vocabulaire des Présocratiques. Ellipses, Paris.

Baldi, B. (1888). Vita di Pitagora. Tip. delle Scienze matematiche e fisiche, Roma.

Bamford, C. e Kisly, L. (2006). 'Common Sense: an Interview with Peter Kingsley'. Parabola, 31 (1): 24-30.

Barbera, A. (1981). 'Republic 530C-531C: Another Look at Plato and the Pythagoreans'. The American Journal of Philology, 102 (4): 395-410.

Barnes, J. (1982). The Presocratic Philosophers, second revised edition. Routledge and Kegan Paul, London.

Bertermann, W. (1913). De Iamblichi Vitae Pythagoricae fontibus. Regimonti: Ex officina Hartungiana, Königsberg.

Bechtle, G. (2003). 'Pitágoras: entre ciência e vida'. In M. Erler e A. Graeser. Filósofos da Antiguidade. Ed. Unisinos, São Leopoldo: 52-75.

Becker, O. (1957). Zwei Untersuchungen zur antiken Logik. Otto Harassowitz, Wiesbaden.

Bellido, A. M. (1972). Atenas y el pitagorismo: investigación en las fuentes de la comedia. Universidad de Salamanca, Salamanca

Bernabé, A. (1998).'Platone e l'orfismo'. In G. Sfameni Gasparro (a cura di), Destino e salvezza: tra culti pagani e gnosi cristiana. Itinerari storicoreligiosi sulle orme di Ugo Bianchi. Giordano, Cosenza: 37-97.

- (2000). 'Nuovi frammenti orfici e una nuova edizione degli Orphika'. In Tortorelli Ghidini, M.; Marino, A. S. e Visconti A. Tra Orfeo e Pitagora: origini e incontri di culture nell'antichità. Atti dei seminari napoletani 1996-98. Bibliopolis, Napoli: 44-80. 
- (2002).'Orphisme et Présocratiques: bilan et perspectives d'un dialogue complexe'. In Laks, A., Louget, C. (eds.). Qu'est-ce que la philosophie présocratique? What is presocratic philosophy?, Presses Universitaires du Septentrion, Villeneuve d'Ascq.

- (2004). Textos órficos y filosofía presocrática. Materiales para una comparación. Editorial Trotta, Madrid.

_ _ (2007a). 'Lâme après la mort: modèles orphiques et transposition platonicienne'. In Pradeau, J. F (ed.), Études platoniciennes IV, Les puissances de l'âme selon Platon, Les Belles Lettres, Paris: 25-44.

- _ (2007b). 'La muerte es vida. Sentido de una paradoja órfica'. In Bernabé,A

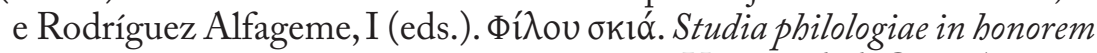
Rosae Aguilar ab amicis et sodalibus dicata. Universidad Complutense, Madrid: $175-181$.

- (2011). Platão e Orfeu (Coleção Archai, 5). Tradução de Dennys G. Xavier. Annablume, São Paulo.

Bernabé, A., Casadesús, F. (2009). Orfeo y la tradición órfica. Un reencuentro. Akal, Madri.

Bernabé, A., Jiménez San Cristóbal, A. I (2008). Instructions for the Netherworld: The Orphic Gold Tablets. With an Iconographical Appendix by R. Olmos, and Illustrations by S. Olmos. Translated by M. Chase. Koninklijke Brill NV, Leiden/Boston.

Bestor, T. W. (1980). 'Plato's Semantics and Plato's Parmenides'. Phronesis, 25 (1): $38-75$.

Betegh, G. (2004). The Derveni Papyrus. Cosmology, Theology, and Interpretation, Cambridge University Press, Cambridge.

_- (2006). 'Escatology and Cosmology. Models and Problems'. In Sassi M. M. La costruzione del discorso filosofico nell'età dei Presocratici. Edizioni della Normale, Pisa: 27-50.

Biondi, G. (2009). La favola di Euforbo e Pitagora. Manifestolibri, Roma.

Boas, G. (1948). 'The Role of Protophilosophies in Intellectual History'. Journal of Philosophy, vol. 45: 673-684.

Boeckn, A. (1819). Philolaos des Pythagoreers Lehren nebst den Bruchstücken seines Werkes. Vossischen Buchhandlung, Berlin.

Boyancé, P. (1966). 'La Storia del Pitagorismo Romano par Leonardo Ferrero'. In Università degli Studi di Trieste. Ricordo di Leonardo Ferrero - 29 aprile 1966. Tipografia Moderna, Trieste: 31-37.

- - (1972). Le culte des Muses chez les philosophes Grecs. E. De Boccard, Paris. Bonazzi, M., Lévy, C., Steel, C. (eds.) (2007). A Platonic Pythagoras. Studies on 
Platonism. Turnhout, Brepols.

Brisson, L. (2000a). 'Nascita di un mito filosofico: Giamblico (VP 146) su Aglaophamos'. In Tortorelli Ghidini, M.; Marino, A. S. e Visconti, A. Tra Orfeo e Pitagora: origini e incontri di culture nell'antichità. Atti dei seminari napoletani 1996-98. Bibliopolis, Napoli: 44-80.

- (2000b). Lectures de Platon. Librairie Philosophique J. Vrin, Paris (ed. bras. Leituras de Platão, trad. Sonia Maria Maciel. Edipucrs, Porto Alegre).

Burkert, W. (1960). 'Platon oder Pythagoras? Zum Ursprung des Wortes Philosophie’. Hermes, 88: 159-77.

- (1972). Lore and science in ancient Pythagoreanism, transl. A. L. Minar Jr. Cambridge University Press, Cambridge.

- (1977). Griechische Religion der archaischen und klassischen Epoche. Stuttgart (ed. italiana: I Greci. Storia delle Religioni, vol. 8, 2 tomi, trad. Piero Pavanini, prefazione di Giulia Sfameni Gasparro. Jaca Book, Milano, 1984).

- (1980). 'Neue Funde zur Orphik'. Informationen zum altsprachlichen Unterricht, vol. 2: 27-42.

(1982). 'Craft versus Sect: The Problem of Orphics and Pythagoreans'. In Meyer, Ben F., Sanders, E. P. (eds.) Jewish and Christian Self-definition (Self-Definition in the Greco- Roman World, 3). Fortress Press, Philadelphia: 1-22.

- (1998). 'Pythagoreische Retraktationen: Von den Grenzen einer möglichen Edition. In Burkert, W. (org.). Fragmentsammlungen philosophischer Texte der Antike. Atti del Seminario Internazionale Ascona, Centro Stefano Franscini 22-27 Settembre 1996. Vandenhoek \& Ruprech, Göttingen: 302-319.

_- (2005).'La teogonia originale di Orfeo secondo il Papiro di Derveni. In Guidorizzi, G. e Melotti, M. (eds.). Orfeo e le sue metamorfosi: mito, arte e poesia. Carocci, Roma: 46-64.

Burnet, J. (1908). Early Greek Philosophy. Adam and Charles Black, London. Burnyeat, M. F (2005). 'Archytas and the Optics'. Science in Context, 18 (1): 35-53.

Bywater, I (1868). 'On the Fragments attributed to Philolaus the Pythagorean'. Journal of Philology, 1: 21-53.

Caldas Aulete, F. J. de (ed.) (1958). Dicionário Contemporâneo da Lingua Portuguesa, 5 vols. Delta, Rio de Janeiro.

Calogero, G. (1932). Studi sull'Eleatismo. Tipografia Bardi, Roma.

__ (1941). 'Dal Diels al Kranz'. Gnomon, 17, fasc. V e VI. 
Cambiano, G. (1992). 'Figura e numero'. In M. Vegetti (org.). Introduzione alle culture antiche II: il sapere degli antichi. Bollati Boringhieri, Torino: 83-109.

Cameron, A. (1938). The Pythagorean Background of the Theory of Recollection. George Banta, Wisconsin.

Canfora, L. (2002). Noi e gli antichi. Perché lo studio dei greci e dei romani giova all' intelligenza dei moderni. Milano, Rizzoli.

Capparelli, V. (1941). La sapienza di Pitagora. Casa editrice dott. A. Milani, Padova.

Carcopino, J. (1956). De Pythagore aux Apôtres. Études sur la conversion du monde romain. Flammarion, Paris.

Casadio, G. (1987). 'Adversaria Orphica. A proposito di un libro recente sull'Orfismo'. Orpheus, 8: 381-395.

__ (1991). La metempsicosi tra Orfeo e Pitagora'. In P. Borgeaud (org.). Orphisme et Orphée, en l'honneur de Jean Rudhardt (Recherches et Rencontres. Publications de la Faculté des Lettres de Genève, 3). Librairie Droz, Genève: 119-155.

Casertano, G. (1987). 'Due note sui primi Pitagorici'. In VVAA, Filologia e forme letterarie. Studi offerti a F. Della Corte Universitá Degli Studi Di Urbino, Urbino, vol.V: 5-25.

- (1988). 'I pitagorici e il potere'. In Casertano, G. (org.). I fllosofi e il potere nella società e nella cultura antiche. Guida, Napoli: 15-27.

__ (1989). 'Filosofare dialektikos in Platone: il Filebo (L'eterna malattia del discorso)'. Elenchos 10: 61-102.

_- (2007a). 'Una volta fui arbusto e muto pesce del mare'. In Casertano, G. Empedocle tra poesia, medicina, filosofia e politica. Loffredo, Napoli: 331337.

__ (2007b).'Verdade e erro no Poema de Parmênides'. Anais de Filosofia Clássica, 2 (1): 1-16.

—_ (2009). I presocratici. Carocci, Roma.

Casini, P. (1998). L'antica sapienza italica: cronistoria di un mito. Il Mulino, Bologna.

Centrone, B. (1990). Pseudopythagorica Ethica: i trattati morali di Archita, Metopo, Teage, Eurifamo. Bibliopolis, Napoli.

__ (1992). 'L'VIII libro delle "Vite" di Diogene Laerzio'. In W. Haase (ed.). Aufstieg und Niedergang der römischen Welt, 36 - Philosophie, Wissenschaften, Technik. Walter De Gruyter, Berlin: 4183-4217. 
(1996). Introduzione ai Pitagorici. Laterza, Bari/Roma.

(1998). 'Alcmeon de Crotone'. In R. Goulet (org.). Dictionnaire des Philosophes Antiques, vol. I. CNRS Editions, Paris: 116-117.

(1999). 'Recensione a L. Zhmud. Wissenschaft, Philosophie u. Religion im früher Pythagoreismus, Akademie Verlag, Berlin, 1997'. Elenchos, anno XX, vol. 2: 420-426.

- (2000). Cosa significa essere pitagorico in età imperiale: per una riconsiderazione della categoria storiografica del neo pitagorismo. In A. Brancacci. La filosofia in età imperiale: le scuole e le tradizioni flosofiche. Bibliopolis, Napoli, 139-167.

Cherniss, H. (1935). Aristotle's Criticism of Presocratic Philosophy. Johns Hopkins Press, Baltimore.

__ (1944). Aristotle's Criticism of Plato and the Academy. Johns Hopkins Press, Baltimore.

- (1945). The riddle of the Early Academy. University of California Press and Cambridge University Press, Berkeley/Cambridge.

- (1951). 'The Characteristics and Effects of Presocratic Philosophy'. Journal of the History of Ideas, 12 (3): 319-345.

—_ (1977). Selected Papers, ed. L. Tarán. E. J. Brill, Leiden.

Chevitarese, A. L. (2004). 'O plêthos urbano e os vestígios pitagóricos na comédia antiga ateniense'. Boletim do Centro de Pensamento Antigo, 16: 135-148.

Ciaceri, E. (1931-1932). 'Orfismo e pitagorismo nei loro rapporti politicosociali'. Atti dell'Accademia di Archeologia, Lettere e Belle Arti, n. s. XII: 209-223.

Colli, G.(1977). La sapienza greca, vol. I. Adelphi, Milano.

Collobert, C. (2002). 'Aristotle's review of the presocratics'. Journal of the History of Philosophy, 40 (3): 281-295.

Cornelli, G. (2002). “Os óculos de Aristóteles e a história pitagórica: pluralidade e contradição nas origens da filosofia ocidental". Boletim do Centro de Pensamento Antigo, 12: 153-172.

__ (2003a). 'Caminhos de duas mãos: trocas filosóficas entre pitagorismo e platonismo'. Boletim do Centro de Pensamento Antigo, 15: 43-54.

- (2003b). 'O pitagorismo em suas origens: fontes, comunidade, metempsicose e cosmologia'. Boletim do Centro de Pensamento Antigo, 16: 191-208.

__ (2003c). 'As origens pitagóricas do método filosófico: o uso das archai 
como princípios metodológicos em Filolau'. Hypnos, 11: 71-83.

(2006). 'Metempsicosis y anamnesis: el diálogo platónico con las tradiciones religiosas de su tiempo'. Limes, 16: 47-59.

_- (2007b). 'Filosofia Antiga Underground: da Katábasis ao Hades à Caverna de Platão'. REVER, ano 7: 94-107.

—_ (2009a). 'Calcular a saúde: a saúde como equilíbrio de forças na tradição pitagórica'. In Miriam C. D. Peixoto. (org.). A saúde dos antigos: reflexões gregas e romanas. Edições Loyola, São Paulo: 33-42.

—_ (2009b). 'Platão aprendiz do teatro: a construção dramática da filosofia política de Platão'. In Funari, P. P. et al. (orgs.). Politica e identidades no mundo antigo. Annablume, São Paulo: 73-86.

- (2010). 'Una città dentro le città: la politica pitagorica tra i lógoi di Pitagora e le rivolte antipitagoriche'. In: Cornelli, G.; Casertano. G. (orgs.). Pensare la città antica: categorie e rappresentazioni. Loffredo, Napoli: 21-38.

Cornelli, G. e Coelho, M. C. M. N. (2007a). 'Quem não é geômetra não entre! Geometria, Filosofia e Platonismo'. Kriterion, 116: 417-435.

Cornford, F. M. (1907). Thucydides Mythistoricus. Edward Arnold, London.

- (1922). 'Mysticism and Science in the Pythagorean Tradition'. The Classical Quarterly, 16: 137-150.

- (1923). 'Mysticism and Science in the Pythagorean Tradition'. The Classical Quarterly, 17: 1-12.

- (1939). Plato and Parmenides: Parmenides 'Way of Truth' and Plato's Parmenides. Kegan Paul, London.

Corssen, P. (1912a). 'Die Sprengung des pythagoreischen Bundes'. Philologus, 71: 332-52.

—_ (1912b). 'Zum Abaris des Heraklides Ponticus'. Rheinisches Museum für Philologie, 67, 20-47.

Creese, D. (2010). The Monochord in Ancient Greek Harmonic Science. Cambridge University Press, Cambridge.

Cumont, F. (1942a). 'Le coq blanc des Mazdeens et les Pythagoriciens'. Comptes rendus de l'Academie des Inscriptions et Belles-Lettres, Paris: 284300.

- (1942b). Recherches sur le symbolism funeraire des Romains. Geuthner, Paris. Curd, P. (1998). The Legacy of Parmenides: eleatic monism and later presocratic thought. Princeton University Press, Princeton.

Cusano, N. (1972). Opere. A cura di G. Federici Vescovini. UTET, Torino. 
D. S. M. (1943), 'Reviewed work: Early Pythagorean Politics in Practice and Theory by Edwin L. Minar, Jr'. The Journal of Philosophy, 40 (3): 79-81.

De Vogel, C. J. (1957). Greek Philosophy: a Collection of Texts, vol. I: Thales to Plato. E. J. Brill, Leiden.

- (1966). Pythagoras and Early Pythagoreanism. An Interpretation of Neglected Evidence on the Philosopher Pythagoras. Van Gorcum, Assen.

(1981). 'The soma-sema formula: its function in Plato and Plotinus compared to Christian writers'. In Blumenthal, H. J. e Markus, R. A. (eds.). Neoplatonism and early Christian thought. Essays in honour of $A$. $H$. Armstrong, Variorum Publ., London: 79-95.

Delatte, A. (1915). Études sur la littérature pythagoricienne. Champion, Paris.

- - (1922a). Essai sur la politique pythagoricienne. Liège, Paris.

- (1922b). La vie de Pythagore de Diogène Laërce. Lamertin, Brussels.

Detienne, M. (1959a). 'La démonologie d'Empédocles', Revue des Études Grecques, 72: 1-17.

__ (1959b). 'Sur la démonologie de l'ancien pythagorisme'. Revue de l'bistoire des religions, 155: 21-31.

- (1962). Homère, Hésiode et Pythagore: poésie et philosophie dans le pythagorisme ancien. Latomus, revue d'études latines (Bruxelles), vols. 55-57.

- (1963). La notion de daimon dan le pythagorisme. Les Belles Lettres, Paris.

- (1970). 'La cuisine de Pythagore'. Archives des sciences sociales des religions, 29 (1): 141-162.

- (1972). Les Jardins d'Adonis. Gallimard. Paris. (ed. americana The Gardens of Adonis, trad. Janet Lloyd. Princeton University Press, Princeton, 1977).

- (2000). Comparer l'incomparable. Seuil, Paris.

Diels, H. (1890). 'Ein gefalschtes Pythagorasbuch'. Archiv für Geschichte der Philosophie, 3: 451-472.

Diès, A. (1927). Autour de Platon. Essais de critique et d'histoire, 2 vols. Gabriel Beauchesne, Paris/Besançon.

Dillon, J. M. (1977). The Middle Platonists. Cornell University Press, Ithaca.

- (2003). The Heirs of Plato: A Study of the Old Academy (347-274 BC). Oxford University Press, Oxford.

Dindorf, W. (1855). Scholia Graca in Homeri Odysseam. Kessinger Publishing, Oxford.

Dodds, E. R. (1951). The Greeks and The Irrational. University of California 
Press. Berkeley.

Döring, A. G. P. (1892). 'Wandlungen in der pythagoreischen Lehre'. Archiv für Geschichte, 5: 503-531.

Drosdex, A. (2007). Greek Philosophers as Theologians: the Divine Arche. Ashgate, Hampshire.

Dubois, L. (1996). Inscriptions grecques dialectales d'Olbia du Pont. Librairie Droz, Genève.

Federico, E. (2000). 'Euforbo/Pitagora genealogo dell'anima'. In Tortorelli Ghidini, M.; Marino, A. S., Visconti A. Tra Orfeo e Pitagora: origini e incontri di culture nell'antichità. Atti dei seminari napoletani 1996-98. Bibliopolis, Napoli: 367-396.

Feldman,L.H. (1963). 'Reviewed work: Homère, Hésiode et Pythagore: Poésie et philosophie dans le pythagorisme ancien by Marcel Detienne'. The Classical World, 57 (1): 16.

- (1968). 'Reviewed work: Pythagoras and Early Pythagoreanism. An Interpretation of Neglected Evidence on the Philosopher Pythagoras by C. J. de Vogel'. The Classical World, 61 (9): 402.

Ferrero, Leonardo (1955). Storia del Pitagorismo nel mondo romano, Dalle origini alla fine della repubblica. Victrix, Torino.

Ferwerda, R. (1985). 'The meaning of the word $\sigma \tilde{\omega} \mu \alpha$ in Plato's Cratylus 400c', Hermes, 113: 266-279.

Festugière, A. J. (1972). Etudes de religion Grecque et hellenistique. Librairie philosophique J. Vrin, Paris.

Frank, E. (1923). Plato und die sogenannten Pythagoreer. Ein Kapitel aus der Geschichte des griechischen Geistes. Max Niemeyer, Halle.

— - (1943). 'Pythagorean Politics in Southern Italy. An Analysis of the Sources by Kurt von Fritz'. The American Journal of Philology, 64 (2): 220-225.

—_ (1955). 'Knowledge, Will and Belief', In L. Edelstein (ed.). Collected essays - Wissen, Wollen, Glauben. Gesammelte Aufsätze zur Philosophiegeschichte und Existentialphilosophie. Artemis, Zürich/Stuttgart.

Gaiser, K. (1963). Platons Ungeschriebene Lehre: Studien zur Systematischen und Geschichtlichen Begründung der Wissenschaften in der Platonischen Schule. Ernst Klett, Stuttgart.

_- (1988). La metafisica della storia in Platone. Traduzione di G. Reale. Vita e Pensiero, Milano.

Gazzinelli, G. G. (2007). Fragmentos órficos. Editora UFMG, Belo Horizonte. 
Gemelli, M. L. M. (2006). 'Resenha de Kinsgley. Reality'. Gnomon. Kritische Zeitschrift für die gesamte klassische Altertumswissenschaft, 78. Verlag C. H. Beck, München: 657-672.

—_ (2007a). Democrito e l'Accademia. Studi Sulla Trasmissione Dell'atomismo Antico da Aristotele a Simplicio. Walter De Gruyter, Berlin/New York.

—_ (2007b). Die Vorsokratiker. Band I. Artemis \& Winkler, Düsseldorf.

Gigon, O. (1945). Der Ursprung der griechischen Philosophie: Von Hesiod bis Parmenides. Benno Schwabe, Basel.

Gomperz, T. (1893-1902). Griechische Denker. Eine Geschichte der antiken Philosophie. Leipzig (ed. castellana Pensadores Griegos: historia de la filosofía de la antigüedad, 3 vols., trad. Carlos Guillermo Körner, con un Prólogo de J. Natalicio González. Editorial Guarania, Asunción del Paraguay, 1951; Asunción/Buenos Aires, 1952).

Gosling, J. (1999). 'Y a-t-il une forme de l'indéterminé?', In M. Dixaut (org.). La fêlure du Plasir. Études sur le Philèbe de Platon. 2 vols. Vrin, Paris: 4359.

Goulet, R. (2001). Études sur les Vies de philosophes de l'Antiquité tardive. Diogène Laërce, Porphyre de Tyr, Eunape de Sardes. Librairie Philosophique J. Vrin, Paris.

Graf, F. (2000). 'Text and Ritual. The Corpus Eschatologicorum'. In Cerri, G. La letteratura pseudoepigrafa nella cultura greca e romana. Atti di un incontro di studi. Napoli, 15-17 Gennaio 1998. Annali dell'Università di Napoli l'Orientale (AION), Filol.22: 59-77.

Guthrie, W. K. C. (1952). Orpheus and Greek Religion. Harrison, London.

_- (1957). 'Aristotle as a Historian of Philosophy: Some preliminaries'. Journal of Hellenic Studies, 77: 35-41.

- - (1962). A history of Greek Philosophy, vol. I: the Earlier Presocratics and the Pythagoreans. Oxford University Press, Oxford.

Hadot, P. (1999). O que é flosofia antiga? Loyola, São Paulo.

Heath, T. (1921). A History of Greek Mathematics, 1 vol. Clarendon Press, Oxford.

Heidel, W. A. (1940). 'The Pythagoreans and Greek Mathematics'. American Journal of Philology, 61 (1): 1-33.

Huffman, C. A. (1985). 'The Authenticity of Archytas Fr. 1'. Classical Quarterly, 35 (2): 344-348.

(1988). 'The Role of Number in Philolaus' Philosophy'. Phronesis, 33 1): 1-30. 
- (1993). Philolaus of Croton: Pythagorean and Presocratic. A Commentary on the Fragments and Testimonia with Interpretive Essays. Cambridge University Press, Cambridge.

- (2005).Archytas of Tarentum: Pythagorean, Philosopher and Mathematician King. Cambridge University Press, Cambridge.

- (2006). 'Aristoxenus Pythagorean Precepts: a rational Pythagorean ethics'. In Sassi M. M. La costruzione del discorso fllosofico nell' età dei Presocratici. Edizioni della Normale, Pisa: 103-21.

_- (2007). 'Philolaus and the central fire'. In Stern-Gillet, G., Corrigan K. Reading Ancient Texts. Vol. I: Presocratics and Plato, Essays in Honour of Denis O'Brien. Koninklije Brill NV, Leiden.

- _ (2008a). 'Another Incarnation of Pythagoras'. Ancient Philosophy, 28: 201-226.

- (2008b).'The Pythagorean precepts of Aristoxenus: crucial evidence for Pythagorean moral philosophy'. The Classical Quarterly, 58 (1): 104-119.

- (2008c). 'Two problems in Pythagoreanism'. In P. Curd, D. W. Graham (eds.). The Oxford Handbook of Presocratic Philosophy. Oxford University Press, Oxford: 284-304.

Isnardi Parente, M. (1971). 'Per l'interpretazione di Aristotele, De anima I, 404b 18 ss.' In R. Palmer, R. Hamerton-Kelly (eds.). Philomathes. Studies in memory of Philip Merlan. The Hague, 1971:146-169.

__ (1977). 'Dottrina delle idee e dottrina dei principi nell'Accademia antica'. Annali della Scuola Normale Superiore di Pisa, serie III, 7 (3): 1017-1128.

- (1989). L'eredità di Platone nell'Accademia antica. Guerini, Milano.

ISO 843 (1997). Conversion of Greekcharacters into Latin characters-Information and documentation. International Organization for Standardization, Geneva.

Jaeger, W. (1928). 'Über Ursprung und Kreislauf des philosophischen Lebensideals'. Sitzungsberichte der Preussischen Akademie der Wissenschaften: 390-421.

- (1934). Aristotle: Fundamentals of the History of his Development (1924). Translated, with the author's corrections and additions, by Richard Robinson. Clarendon Press, Oxford.

- (1947). The Theology of the Early Greek Philosophers (Gifford Lectures, 1936-1937). Oxford University Press, Oxford.

Joost-Gaugier, C. L. (2009). Pythagoras and Renaissace Europe: Finding Heaven. Cambridge University Press, Cambridge.

Kahn, C. H. (1969). 'The thesis of Parmenides'. The Review of Metaphysics, 22 
(4): 700-724.

—_ (1974). 'Pythagorean Philosophy before Plato'. In Mourelatos A. The Pre-socratics. Anchor/Doubleday, New York.

- (2001). Pythagoras and the Pythagoreans: a Brief History. Hackett Publications, Cambridge.

Kahrstedt,U.(1918).'Zur Geschichte Grossgriechenlands im 5.Jahrhundert'. Hermes, 53:180-187.

Kees, H. (1956). Totenglauben und jenseitsvorstellungen der alten Agypter. Akademie-Verlag, Berlin.

Kerényi, K. (1950). Pythagoras und Orpheus. Rhein-Verlag, Zürich.

Kerferd, G. B (1965). ' $\triangle$ AIM $\Omega$ N in Pythagorean Thought'. Resenha de "La notion de $\delta \alpha i ́ \mu \omega v$ dans le pythagorisme ancien de Marcel Detienne". The Classical Review, new series, 15 (1): 77-79.

—_ (1968). 'What Can We Know of Pythagoras?' Reviewed work: "Pythagoras and Early Pythagoreanism: An Interpretation of Neglected Evidence of the Philosopher Pythagoras, by C. J. de Vogel". The Classical Review, new series, 18 (3): 282-284.

Kern, O. (1888). 'Empedokles und die Orphiker'. Archiv für Geschichte der Philosophie, 1 (4): 498-508.

Kingsley, P. (1994). 'Philolaus: Review of Pbilolaus of Croton: Pythagorean and Presocratic by Carl A. Huffman'. The Classical Review, new series, 44 (2): 294-296.

- (1995). Ancient Philosophy, Mystery and Magic: Empedocles and the Pythagorean Tradition. Clarendon Press, Oxford.

- (1999). In the dark places of wisdom. Golden Sufi Publishing, Inverness.

- (2003). Reality. Golden Sufi Publishing, Inverness.

- (2010). A Story Waiting to Pierce you: Mongolia, Tibet and the Destiny of the Western World. The Golden Sufi Center, Point Reyes (CA).

Kirk, G. S., Raven, J. E., Schofield, M. (1983). The Presocratic Philosophers. 2nd edition. Cambridge University Press, Cambridge.

Knorr, W. R (1975). The Evolution of the Euclidean Elements. D. Reidel, Dordrecht/Boston.

Krämer, H. (1959). Arete bei Platon und Aristoteles. Zum Wesen und zur Geschichte der platonischen Ontologie. Akademie der Wissenshaften, Heidelberg.

Kranz, W. (1934). 'Vorsokratisches I'. Hermes, 69: 114-119; 'Vorsokratisches II'. Hermes, 69: 226-228. 
Krische, A. B (1830). De societatis a Pythagora in urbe Crotoniatarum scopo politico commentatio. Typis Dieterichianis, Göttingen.

Laks, A. (2007). Histoire, Doxographie, vérité: études sur Aristote, Théophraste et la philosophie présocratique. Éditions Peeters, Louvain-La-Neuve.

Laks, A., Most, G.W.(1997). Studies on the Derveni Papyrus. Oxford University Press, Oxford.

Lee, H. D. P. (1936). Zeno of Elea. Cambridge Press, Cambridge.

Leszl, W. (1981). 'Il dibattito attuale su platonismo e pitagorismo nell'Accademia antica: un recente saggio di M. Isnardi Parente'.Dialoghi di Archeologia, 1, nuova serie, 3: 113-124.

LÉvy, I (1926). Recherches sur les sources de la légende de Pythagore. Leroux, Paris.

_- (1927). La légende de Pythagore de Grèce en Palestine. Librairie Ancienne Honoré Champion, Paris.

- (1965). Recherces esséniennes et pythagoriciennes. Librairie Droz/Minard, Genève/Paris.

Lloyd, G. E. R. (1989). The Revolutions of Wisdom. University of California Press, Berkeley.

Lohmann, J. (1970). Mousike und Logos: Aufsätze zur griechischen Philosophie und Musiktheorie. Musikwissenschaftliche Verlags-Gesellschaft, Stuttgart.

Long, H. S. (1948). A Study of the doctrine of metempsychoses. Princeton University Press, Princeton.

Macris, C. (2003). 'Pythagore, un maître charismatique de la fin de la période archaïque'. In G. Filoramo (ed.). Carisma profetico: fattore di innovazione religiosa. Morcelliana, Brescia: 243-289.

Maddalena, A. (1954). I pitagorici. Laterza, Bari.

Mansfeld, J. (1986). 'Aristotle, Plato and the Preplatonic Doxography and Chronography'. In Cambiano, G. (ed.). Storiografia e dossografia nella filosofia antica. Tirrenia stampatori, Torino: 1-59.

- (1990). 'Aristotle, Plato, and the Preplatonic Doxography and Chronography'. In Mansfeld, J. Studies in the Historiography of Greek Philosophy. Van Gorcum, Assen/Maastricht: 22-83.

Martin, A. e Primavesi, O. (1998). Empedocles de Strasbourg. Walter de Gruyter, Berlin/New York.

Masaracchia, A. (1993).'Orfeo e gli orfici in Platone'. In A. Masaracchia (ed.). Orfeo e l'orfismo. Atti del seminario nazionale (Roma/Perugia 1985-1991). Quaderni Urbinati di Cultura Classica (Atti), Roma: 
173-197.

May, J. M. F (1966). The coinage of Abdera (540-345 B.C). Royal Numismatic Society, London.

Meattini, V. (1983). 'Quomodo vivendum est? Appunti sul pitagorismo del Gorgia'. Annali dell'Istituto Italiano di Studi Storici, 6, 1979/1980 (1983): 9-29.

Mele, A. (1982). 'La Megale Hellas pitagorica: aspetti politici, economici e sociali'. In Megale Hellas. Nome e Immagine. Istituto per la storia e l'archeologia della Magna Grecia, Napoli.

_- (2000). 'Megale Hellas e pitagorismo'. In Tortorelli Ghidini, M.; Marino, A. S., Visconti, A. Tra Orfeo e Pitagora: origini e incontri di culture nell'antichità. Atti dei seminari napoletani 1996-98. Bibliopolis, Napoli: 297-334.

- (2007). Colonie achee e pitagorismo. Luciano Editore, Napoli.

Meriani, A. (2003). ‘Teoria musicale e antiempirismo'. In Platone. Repubblica. Vol. V, Libri VI-VII. Traduzione e commento a cura di Mario Vegetti. Bibliopolis, Napoli: 565-602.

Migliori, M. (1993). L'uomo fra piacere, intelligenza e bene. Commentario storico-filosofico al "Filebo" di Platone. Vita e Pensiero, Milano.

Minar Jr., E. L. (1942). Early Pythagorean Politics in Practice and Theory. Waverly Press, Baltimore.

- (1964). 'Reviewed work: Weisheit und Wissenschaft. Studien zu Pythagoras, Philolaos und Platon by Walter Burkert and Pythagoras: Leben und Lehre in Wirklichkeit und Legende by Ernst Bindel'. The Classical World, 58 (4): 120-121.

Montepaone, C. (2011). Pitagoriche: scritti femminili di età ellenistica. Edipuglia, Bari, 2011.

Morgan, M. L. (1997). '[Review of] Peter Kingsley. Ancient Philosophy, Mystery, and Magic. The American Historical Review, 102 (4): 11291131.

Morrison, J. S. (1956). 'Pythagoras of Samos'. Classical Quarterly, 50 (new series, 6): 135-156.

Mourelatos, A. (1970). The Route of Parmenides. Yale University Press, New Haven.

Murari, F. (2002). 'Mito e Tragédia em Tucídides: a leitura de Francis M. Cornford'. Letras Clássicas, 6: 135-144.

Musti, D. (1990). 'Le rivolte antipitagoriche e la concezione pitagorica del tempo'. Quaderni Urbinati di Cultura Classica, nuova serie, 36 (3): 35-65. 
Navia, L. E. (1990). Pythagoras: An Annotated Bibliography. Garland, New York.

Nietzsche, F. W.(1878). 'Zur Geschichte der Theognideischen Spruchsammlung'. Rheinisches Museum für Philologie, 22: 161-200.

__ (1994). I filosofi preplatonici, a cura di Piero Di Giovanni. Laterza, Roma/ Bari.

Nilsson, M. P. (1935). 'Early orphism and kindred religious movements', Harvard Theological Review, 28 (3): 181-230.

NuccI, M. (1999). '[Recensione Bibliografica a] Kingsley P. Ancient Philosophy, Mistery and Magic'. Elenchos, anno XX, fasc. 2: 427-438.

Nussbaum, M. (1979).'Eleatic Conventionalism and Philolaus on the Conditions of Thought'. Harvard Studies in Classical Philology, 83: 63108.

O’Brien, D. (1998). 'Reviewed work: Ancient Philosophy, Mystery, and Magic: Empedocles and Pythagorean Tradition by Peter Kingsley'. Isis, 89 (1): 122-124.

O’Meara, D. (1989). Pythagoras revived. Mathematics and Philosophy in Late Antiquity. Clarendon Press, Oxford, 1989.

Pascal, B. (1904). Graecia Capta. Successori Le Monnier, Firenze.

Peixoto, M. (2009). 'Kairos e Metron: a saúde da alma na therapeia do corpo'. In M. Peixoto (org.). A saúde dos antigos: reflexões gregas e romanas. Loyola, São Paulo: 55-66.

Philip, J. A. (1959). 'The Biographical Tradition-Pythagoras'. Transactions and Proceedings of the American Philological Association, 90: 185-194.

- (1966). Pythagoras and Early Pythagoreanism. University of Toronto Press, Toronto.

Pollard, J. R. T. (1964). 'Reviewed work: Homère, Hésiode et Pythagore: poésie et philosophie dans le pythagorisme ancien by Marcel Detienne'. The Journal of Hellenic Studies, 84, 188.

Prier, R. A. (1978). ' $\Sigma \tilde{\eta} \mu \alpha$ and the symbolic nature of pre-Socratic thought'. Quaderni Urbinati di Cultura Classica, 29: 91-101.

Prontera, F. (1976-77). ‘Gli “ultimi” pitagorici. Contributo per una revisione della tradizione'. Dialoghi di archeologia, 9-10: 267-332.

Pugliese Carratelli, G. (2001). Le lamine d'oro orfiche: istruzioni per il viaggio oltremondano degli iniziati greci. Adelphi, Milano.

Rathmann, G. G. [= W. W.] (1933). Quaestiones Pythagoreae Orphicae Empedocleae, Phil. Dissertatio inauguralis. Halis Saxonum (Halle) 
(Reissued in Pythagoreanism II. Garland, New York: 1987).

Raven, J. E. (1948). Pythagoreans and Eleatics. An Account of the Interaction between the Two Opposed Schools during the Fifth and the Early Fourth Centuries BC. Cambridge University Press, Cambridge (reprint Ares Publishers, Chicago, 1966).

Reale, G. (1968). Storia della Filosofia Antica, vol. 5. Vita e Pensiero, Milano.

(1991). Per una nuova interpretazione di Platone: rilettura della metafisica dei grandi dialoghi alla luce delle Dottrine non scritte. Vita e Pensiero, Milano.

Redfield, J. (1991). 'The Politics of Immortality'. In P. Borgeaud (org.). Orphisme et Orphée, en l'honneur de Jean Rudhardt (Recherches et Rencontres. Publications de la Faculté des Lettres de Genève, 3). Librairie Droz, Genève: 103-118.

Reinhardt, K.(1916). Parmenides und die Geschichte der griechischen Philosophie. Bonn (nachdruck Vittorio Klostermann, Frankfurt, 1985).

Rey, A. (1933). La jeunesse de la science grecque. La Renaissance du Livre, Paris. Rey Puente, F. (2001). Os sentidos do tempo em Aristóteles. Loyola, São Paulo.

- (2010). Ensaios sobre o tempo na Filosofia Antiga (Coleção Archai, 4). Annablume, São Paulo.

Riedweg, C. (1995). 'Orphisches bei Empedokles'. Antike und Abendland, 41: 34-59.

- (2002). Pythagoras: Leben, Lehre, Nachwirkung. C. H. Beck, Munique (ed. italiana Pitagora: vita, dottrina e influenza. Presentazione, traduzione e apparati a cura di Maria Luisa Gatti. Vita e Pensiero, Milano, 2007).

Ries, K. (1959). Isokrates und Platon im Ringen um die Philosophia. Ph. D. Dissertation, München.

Ritter, A. H. (1829-1834). Geschichte der Philosophie, 12 vols.; vols. 1-4 - alter Zeit. Friedrich Perthes, Hamburg.

Robbiano, C. (2006). Becoming Being: on Parmenides'Trasformative Philosophy. Academia Verlag, Sankt Augustin.

Roвbins, F. E. (1921). 'The Tradition of Greek Arithmology'. Classical Philology, 16 (2): 97-123.

Rocconi, E. (2003). Le parole delle muse: la formazione del lessico tecnico musicale nella Grecia Antica (Seminari Romani di Cultura Greca, Quaderni, 5). Ed. Quasar, Roma.

Rohde, E. (1871). 'Die Quellen des Iamblichus in seiner Biographie des Pythagoras'. Rheinisches Museum für Philologie, 26: 554-576. 
- (1872).'Die Quellen des Iamblichus in seiner Biographie des Pythagoras'. Rheinisches Museum für Philologie, 27: 23-61.

_- (1898). Psyche: Seelencult und Unsterblichkeitsglaube der Griechen. J. C. B. Mohr/Paul Siebeck, Leipzig/Tübingen (ed. inglesa Psyche: The Cult of Souls and Belief in Immortality among the Ancient Greeks, transl. W. B. Hillis. Routledge; Kegan Paul, London, 1920).

- (1907). Psyche. Seelencult und Unterblichkeitsglaube der Griechen, 4te Auflage. Mohr Siebeck Tübingen.

Rostagni, A. (1922). 'Un nuovo capitolo nella storia della retorica e della sofistica'. Studi Italiani di Filologia Classica, nuova serie, vol. 2, fasc. 1-I2: 148-201.

- (1982). Il verbo di Pitagora. Il Basilico, Genova.

Salas, O. D. A. (1996). Pitágoras y los Orígenes de la Matemática Griega. Universidad Nacional Autonoma de México, México.

Sandbach, F. H. (1958/59). 'Ion of Chios on Pythagoras'. Proceedings of the Cambridge Philological Society, 5: 36.

Santillana, G. de e Pitts, W. (1951).'Philolaos in Limbo, or: What Happened to the Pythagoreans'Author(s)'. Isis, 42 (2): 112-120.

SAssi, M. M. (1994). 'La filosofia 'italica: genealogia e varianti di una formula storiografica'. In Forme di religiosità e tradizioni sapienziali in Magna Grecia. Atti del Convegno (Napoli 14-15 dicembre 1993), AION Annali dell'Istituto Universitario Orientale di Napoli, n. 16: 29-53.

- (2009). Gli inizi della filosofia: in Grecia. Bollati Boringhieri, Milano.

Scarpi, P. (2007). 'Empedocle mago'. In G. Casertano (org.). Empedocle tra poesia, medicina, filosofia e politica. Loffredo, Napoli, 143-156.

Schleiermacher, F. (1812/13). Ethik. Ed. Hans-Joachim Birkner. Felix Meiner, Hamburg.

Seltman, C. (1933). Greek Coins. Methuen \& Co., London.

Spinelli, M. (2003). Filósofos pré-socráticos: primeiros mestres da filosofia e da ciência grega. Edipucrs, Porto Alegre.

Striker, G. (1970). Peras und Apeiron. Das Problem der Formen in Platons Philebos (Hypomnemata, 30). Vandenhoeck \& Ruprecht, Göttingen.

Stroumsa, G. G. (1997). '[Review:] Peter Kingsley, Ancient Philosophy, Mystery, and Magic: Empedocles and Pythagorean Tradition'. Numen, 44 (2): 211-213.

Szlezák, T. A. (1972). Pseudo-Archytas über die Kategorien. Walter De Gruyter, Berlin. 
- (1985). Platon und die Schriftlichkeit der Philosophie: Interpretationen zu den frühen undmittleren Dialogen. Walter De Gruyter, Berlin.

Szlezák, T. A. (2011). 'Platão e os pitagóricos'. Archai 6: 121-132.

Tambrun-Krasker, B. (1999). 'Marsile Ficin et le "Commentaire” de Pléthon sur les "Oracles Chaldaiques". Accademia: Revue de la Societè Marsile Ficin, 1: 9-42.

TANnery, P. (1887a). La geometrie grecque: comment son bistoire nous est parvenue et ce que nous en savons. Gauthier-Villars, Paris.

__ (1887b). Pour l'histoire de la Science Hellène. De Thalès à Empédocle. Alcan, Paris.

—_ (1899). 'Sur un fragment de Philolaos (A14)'. Archiv für Geschichte der Philosophie, 2 (4): 379-386.

- (1901). 'Orphica'. Revue de Philologie, 25: 313-319.

Tate, J. (1942). 'Pythagoreans in Italy. Reviewed work: Pythagorean Politics in Southern Italy by Kurt von Fritz'. The Classical Review, 56 (2): 74-75.

TAYlor, A. E. (1911). Varia Socratica. Oxford University Press, Oxford.

- (1968). Platone. L'uomo e l'opera. La Nuova Italia, Firenze.

Thesleff, H. (1961). An Introduction to the Pythagorean Writings of the Hellenistic Period. Acta Academiae Aboensis, Åbo.

- (1968). 'Reviewed work: Pythagoras and Early Pythagoreanism. An Interpretation of Neglected Evidence on the Philosopher Pythagoras by C. J. de Vogel'. Mnemosyne, series IV, vol. 21, fasc. 2/3: 298-300.

Thomas, H. W. (1938). EПEKEINA, Untersuchungen über das Überlieferungsgut in den Jenseitsmythen Platons. Inaugural-Dissertation, Würzburg.

Tortorelli Ghidini, M. (2000). 'Da Orfeo agli orfici'. In Tortorelli Ghidini, M.; Marino, A. S.,Visconti A. Tra Orfeo e Pitagora: origini e incontri di culture nell'antichità. Atti dei seminari napoletani 1996-98. Bibliopolis, Napoli: 11-41.

- (2006). Figli della terra e del cielo stellato: testi orfici con traduzione e commento. M. D'Auria, Napoli.

Toynbee, A. J. (1939). A Study of History, 12 vols.; vols. 5 and 6: The Disintegrations of Civilizations, parts 1 and 2. Oxford University Press, Oxford.

Trabattoni, F. (1999). Oralità e scrittura in Platone. Università degli Studi di Milano, Milano.

- (2005). La verità nascosta. Oralità e scrittura in Platone e nella Grecia classica. Carocci, Roma. 
Trépanier, S. (2004). Empedocles: an Interpretation. Routledge, New York/ London.

Ustinova, Y. (2009). Caves and the Ancient Greek Mind: Descending Underground in the Search for Ultimate Truth. Oxford University Press, New York.

Van der Waerden, B. L. (1947-1949). 'Die Arithmetik der Pythagoreer'. Mathematische Annalen, 120 (1947-1949): 676-700.

Vegetti, M. (1989). L'etica degli antichi. Laterza, Roma/Bari.

___(1998).'Adimanto'.In Platone. Repubblica.Vol.II, Libri II-III.Traduzione e commento a cura di Mario Vegetti. Bibliopolis, Napoli: 221-232.

- (1999). Introduzione alla lettura della Repubblica di Platone. Laterza, Roma/Bari.

Viano, C. (org.) (2005). L'Alchimie et ses racines philosophiques. La tradition grecque et la tradition arabe. Librairie Philosophique J. Vrin, Paris.

Vidal-Naquet, P. (1964). 'Homere, Hesiode, Pythagore'. Économies, Sociétés, Civilisations, 19 (5): 1022-1023.

Vinogradov, J. G. (1991).'Zur sachlichen und geschichtlichen Deutung der Orphiker-Plaettchen von Olbia'. In P. Borgeaud. Orphisme et Orphée, en l'bonneur de Jean Rudhardt (Recherches et Rencontres. Publications de la Faculté des Lettres de Genève, 3). Librairie Droz, Genève: 77-86.

Vlastos, G. (1952). 'Theology and Philosophy in Early Greek Thought'. Philosophical Quarterly, 2: 97-123.

- (1963). 'Rev. of H.-J. Kramer, Arete bei Platon und. Aristoteles'. Gnomon, 41: 641-55.

Von Fritz, K. (1940). Pythagorean Politics in Southern Italy. An Analysis of the Sources. Columbia University Press, New York.

- (1945). 'The Discovery of Incommensurability by Hippasos of Metapontum'. Annals of Mathematics, 2 (46): 242-264.

- (1957). 'Estris hekatorothi in Pindar's second Olympian and Pythagoras' Theory of Metempsychosis'. Phronesis, 2 (2): 85-89.

- (1964). 'Reviewed work: Weisheit und Wissenschaft. Studien zu Pythagoras, Philolaos und Platon by Walter Burkert'. Isis, 55 (4): 459-461.

West, L. (1982). 'The Orphics of Olbia'. Zeitschrift fur Papyrologie und Epigraphik, 45: 17-29.

- (1983). The Orphic Poems. Clarendon Press, Oxford (ed. italiana I poemi orfici, trad. M. Tortorelli Ghidini. Loffredo, Napoli, 1993).

Wiersma, W. (1942). 'Die Fragmente des Philolaos und das sogenannte 
philolaische Weltsystem'. Mnemosyne, 3 (10): 23-32.

Wilamowitz Moellendorf, U. von (1920). Platon. I, Sein Leben, seine Werken; II, Beilage und Textkritik. Weidmann, Berlin.

—_ (1932). Der Glaube der Hellenen, Weidmann, Berlin.

Wittgenstein,L. (1958). Philosophical Investigations. Transl.E. M. Anscombe. Blackwell, Oxford.

Zeller, E., Mondolfo, R. (1938). La fllosofia dei greci nel suo sviluppo storico. Trad. R. Mondolfo. La Nuova Italia, Firenze.

Zhmud, L. J (1989). “All Is Number?” "Basic Doctrine” of Pythagoreanism Reconsidered'. Phronesis, 34: 270-292.

- (1992). 'Mathematici and Acusmatici in the Pythagorean School'. In Boudouris K. (ed.). Pythagorean Philosophy. International Center for Greek Philosophy and Culture, Athens.

—_ (1997). Wissenschaft, Philosophie und Religion im frühen Pythagoreismus. Akademie Verlag, Berlin.

Zucconi, M. (1970). 'La tradizione dei discorsi di Pitagora in Giamblico, Vita Pythagorica 37-57’. Rivista di Filologia e di Istruzione Classica, 98 (4): 491-501.

Zuntz, G.(1971). Persephone: Three Essays on Religion and Thought in Magna Graecia. Clarendon Press, Oxford. 


\section{INDEX LOCORVM}

Agostinho

Contra academicos (contra acad.)

P1 32: col. 954

47

Retractationes (retr.)

P1 32: col. 58-9

Alcmeão

$24 \mathrm{~b} 4 \mathrm{dk}$

115

Alexandre de Afrodísia

Comentários sobre a metafísica

de aristóteles (in metaph.)

186

Alexis

A pitagórica

fr. 201 kassel-austin $=58 \mathrm{e} 1 \mathrm{dk}$

92

Ambrósio

Enarratio in psalmos (in salm.)

P1 15: col. 1275

Anaxímenes

$13 \mathrm{~b} 2 \mathrm{dk}$

Anônimo LONDInEnse (cf. Filolau)

44 a27-28 dk

Antístenes - cf. Escólios

Escólio sobre a Odisséia
$404 \mathrm{a} 16=67 \mathrm{a} 28 \mathrm{dk} \quad 115,149,150$

404a $21-25$

150

$404 \mathrm{~b} 8=31 \mathrm{~b} 109 \mathrm{a} \mathrm{dk} \quad 121$

404b 29-30 150

De caelo 56

284a23 155

293a20 102

300a16 164

Ética nicomaqueia $(E N)$

1159b: 25-32

86

Física (Phys.)

$203 \mathrm{a}=58 \mathrm{~b} 28 \mathrm{dk} \quad 187,202,203$

$219 \mathrm{~b} 6-7$

189

313b 23-27

188

Metafísica (Met.)

$985 \mathrm{~b} 23$

985b 23-26

$985 \mathrm{~b} 25$

$56,82,164,166$

164,166

183

985b 27-32

986

167,204

103

121

986a $3 \quad 164,200$

986a 12

56

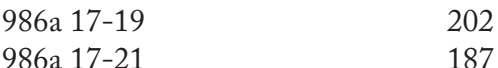

986a 21

986a $22 \quad 167$

987a 13-19 186

987a $28 \quad 182$

987a $29 \quad 56,61,179$

987a 29-31 182

$987 \mathrm{~b} \quad 182$

987b $11 \quad 167$

De anima (De An.) 
987b 11-12

987b 11-14

182

987b $14-988$ a 8

165

987b 18-22

987b 22-25

987b 25-33

987b 27

987b 28

987b 29

987b 33 - 988a 2

$989 \mathrm{~b}$

989b 29

990a 7-13

990a 14-16

990a 16-17

990a 18-22

990a 21

990a 27

$996 \mathrm{a} 4$

1074b 1-10

1080b 16-19

1083b 8

1083b 11

1083b 17

1085 a 33

1090a 23-24

1090a 30

1090a 32

1090b 23

1091a 12

1091a 13

1091a15-18

1091a 34 - b 12

1091b 9

1092b 1-13

1092b 8-13

Metereologica (Mete.)

De sensu

Sobre os pitagóricos

fr. 6 rose

fr. 191 rose

fr. 192 rose $=14 \mathrm{a} 7 \mathrm{dk}=$ iambl. Vp: 31

fr. 199 rose

fr. 1 ross = iambl. Vp: 140-143

Aristóxeno

Fr. 14 wehrli

Fr. 15 wehrli $=14 \mathrm{a} 3 \mathrm{dk}$

Fr. 23; 4 wehrli
155

183

183

183,187

60

163

169

185

198

56

189

189

173

189, 203

163

56

56

155

164

56

163

164

167

164

56

164

163

181

173

188

155

155

173

165,168

102

188

131

148

82,192

187

167
Arquitas

$47 \mathrm{~b} 1 \mathrm{dk}$

Cícero

Cato maior

46

Timaeus 219

Tusculanae disputationes (tusc. Disput.) 46

Clemente de Alexandria

Stromata

98

Comédia Ática Intermediária - cf. Alexis

Damascio de Damasco

Deprincipiis

195

Demétrio de Magnésia

D. L. Vitae VIII. 12

De principiis

195

Demócrito

$68 \mathrm{a} 1 \mathrm{dk}=$ d. L. Vitae IX. $38 \quad 149$

$68 \mathrm{b0a}-\mathrm{c} \mathrm{dk} \quad 149$

$68 \mathrm{~b} 1 \mathrm{dk} \quad 149$

68 b84; 244 e 264 dk $\quad 149$

DERVENI, papiro (p. Derv.) - cf. Papiro

Derveni

Dicearco

Fr. 7 wehrli $\quad 110$

Fr. 36 wehrli 110

Diodoro Sículo (Diod. Sic.)

Bibliotheca histórica

111,147

Diógenes LaÉrcio (D. L.)

Vidas e doutrinas dos flósofos ilustres (vitae)

I. $12=$ Heraclid. Fr. 87 Wehrli 216

I. 13

40,77

I. 14

40,77

I. 15

77

III. 6

III. 9-18

176

VII. 46

202

VIII. 3

44,97

VIII. 4-5 = Heraclid. Fr. 89 Wehrli

147 
VIII. 6

VIII. 6-8

92,175

VIII. 10

VIII. 15

VIII. 21

84,175

95

VIII. $36=21 \mathrm{~b} 7 \mathrm{dk}$

VIII. 37

VIII. 43

VIII. 54-56

VIII. 83

VIII. 84

VIII. 85

IX.

IX. 18

IX. 38

EMPÉDOCLES

31 b109a dk = de an. 404b8

121

$31 \mathrm{~b} 109 \mathrm{dk}$

$31 \mathrm{~b} 112 \mathrm{dk}$ 120,121

$31 \mathrm{~b} 115 \mathrm{dk}$ 114

$31 \mathrm{~b} 122 \mathrm{dk}$

121

121

122

$31 \mathrm{~b} 129 \mathrm{dk}$

132

Escólios

Escólios sobre o Fedro

Schol. In Phaedr.: 279c = FgrHist: 566

fr. 13

Escólio Sobre a Odisséia

Schol. In Hom. Odyss. I; 1: 50-63 50

Escólios sobre Sófocles

Schol. In Soph. 62

Espeusipo (Speusip.)

Fr. 4 lang = $44 \mathrm{a} 13 \mathrm{dk}$ (cf. Filolau) 167

Fr. 48 taran 185

Aristóteles; Metafísica 1085a33

167

Ésquilo (Aesch.)

Prometeu (Prom.)

EuríPIDES

A Sábia Melanipe (fr. 495 nauck) 128

Hipólito

Estobeu (Stob.)

Anthologium (Florilegium) 136, 181
Eusébio de Cesaréia

Praeparatio evangélica

Filolau

$44 \mathrm{a} 7 \mathrm{a}$ dk 203

44 a $13 \mathrm{dk}$ (cf. Espeusipo) 142, 167

$44 \mathrm{a} 14 \mathrm{dk}$

44 a27-28 dk (cf. Anônimo

Londinense) 176, 176

$44 \mathrm{a} 29 \mathrm{dk}$

121

$44 \mathrm{~b} 1 \mathrm{dk}$

115, 194, 195

$44 \mathrm{~b} 2 \mathrm{dk}$

197

$44 \mathrm{~b} 3 \mathrm{dk}$

198

$44 \mathrm{~b} 4 \mathrm{dk}$

62,200

$44 \mathrm{~b} 5 \mathrm{dk}$

205

44 b6 1-8 dk $\quad 198$

44 b6 16-24 dk 200

$44 \mathrm{~b} 7 \mathrm{dk}$

199,203

$44 \mathrm{~b} 12 \mathrm{dk}$

177

$44 \mathrm{~b} 13 \mathrm{dk}$

144,188

$44 \mathrm{~b} 14 \mathrm{dk}$

131

$44 \mathrm{~b} 20 \mathrm{dk}$

204

$44 \mathrm{~b} 21 \mathrm{dk} \quad 26$

$44 \mathrm{~b} 22 \mathrm{dk} \quad 133$

Fílon (Filo)

De vita contemplativa

91

Fócio

Biblioteca (Bibl.) 180

Anônimo de Fócio (Anon. Phot. Thesleff) 98

FRAGMENTOS ÓRFICOS

Fr. 23 kern 130

Fr. 32c kern $=4$ a 65 colli $\quad 110$

Fr. 54 kern 130

Heráclito

$22 \mathrm{a} 22 \mathrm{dk}$

$22 \mathrm{~b} 40 \mathrm{dk}$

75,119

$22 \mathrm{~b} 57$ e $106 \mathrm{dk}$

119

$22 \mathrm{~b} 93 \mathrm{dk}$

136

$22 \mathrm{~b} 129 \mathrm{dk}$

118

Heráclides Pôntico

Fr. 87 Wehrli = d. L. Vitae I. 12216

Fr. 89 Wehrli = d. L. Vitae VIII. 4-5 147 
Heródoto (Herodt.
Histórias (Hist.)

II. 12

144

II. 81

143

II. 123

143

IV. 94-96

146

IV. 95

144,146

Hipaso

$18 \mathrm{~b} 7 \mathrm{dk}$

172

Historiógrafos Gregos

FgrHist: 566 f 13 = Schol. In Phaedr.: 279c

FgrHist 1064 f 254

84

Homero

Ilíada (Il.) $123,136,148$

Odisséia (Od.) 136

Íon DE Quios

$36 \mathrm{~b} 2 \mathrm{dk}$ 118

$36 \mathrm{~b} 4 \mathrm{dk}$ 118,120

IsócrATES

Busiris $28-29=14 \mathrm{a} 4 \mathrm{dk}$

92,144

JÂMBLico (Iambl.)

De communi mathematica scientia ( $D e$ comm. Mathem.)

25: 76.16

25: 76.16-78.8

98, 102 100

De vita pythagorica $(V P)$ 1

16,24 218

29

84

30 $44,84,94,96$

$31=14 \mathrm{a} 7 \mathrm{dk}=$ arist. Fr. 192 rose

82,93

$37-57$

31,49

40

88

46

93

52

148

63

120

69-70

88

$71-72$

72

85

73-74

90

74

92

80
81

98, 99

82

85

87

$87-88$

88

96-100

104

130

132

140

140-143

165

185

189

189-194

194

195

229-230

238

239

247

248

$248-257$

249

254

255

257

266

267

Josefo; Flávio

A guerra judaica

91

LÂminas de Ólbia

94a dubois

134

$94 \mathrm{c}$ dubois

134

LÂminas de ThuriI

Fr. 32c kern; 4 a 65 colli

110

LATÂNCIO

De vita beata

P1 6: col. 777

Divinarum institutionum (Div. Inst.)

P1 6; col. 405-9

47 
NumÊNio

Sobre a discordância entre os acadêmicos e Platão

(fr. 24; 73-79 des places)

180

Olimpiodoro

Inphaedon (In Phaed.) 135 westerink 111

ÓRFICOS; FRAGMENTOS - CF. FRAGMENTOS ÓRFICOS

Ovídio

Metamorphoses (Metam.)

122

PAPIRO DERVENI

Col. Xx

126,128

PARMÊnides

$28 \mathrm{~b} 8 \mathrm{dk}$

Petrarca

Triumphus fame III: 7-8

Platão

Carta VII

$339 \mathrm{~d}$

Crátilo (Crat.)

138

$400 \mathrm{c}$ $65,131,133,135$

402 b-c

124

$405 \mathrm{~d}$

81

$409 \mathrm{~b}$

78

Fédon (Phaed.)

$69 \mathrm{c}-\mathrm{d}$

$69 \mathrm{e}-70 \mathrm{a}$

139

$82 \mathrm{a}$

156

$82 \mathrm{e}$

138

85

115

Fedro (Phaedr.)

62b, 67c-d, 81e, 92a 65

$245 \mathrm{c}-246 \mathrm{a} \quad 150$

248 c-e 129

$250 \mathrm{c}$

138

Filebo (Phlb)

$12 \mathrm{c}$

192

$16 \mathrm{~b}$

190

$16 \mathrm{c}$ 185

$16 \mathrm{c}-\mathrm{d}$

190

$16 c-23 c$

189

$16 \mathrm{e}$

190

$17 \mathrm{a}$

190, 191, 198
$17 \mathrm{c}-\mathrm{e}$

191

$17 \mathrm{~d}$

190

$18 \mathrm{~b}$

191

$19 \mathrm{a}$

191

$23 \mathrm{c}-\mathrm{d}$

192

$66 \mathrm{c}$

124

Górgias (Gorg.)

492 e - 493 c

131

503 e -504 a

131

$492 \mathrm{e}$

134, 153

Leis (Leg.)

$715 \mathrm{e}$

124

$739 \mathrm{c}$

87

VI, 782 c

124

X, 895

150

Lisis

207 c

87

Mênon (Men.)

$80 \mathrm{~d}$

$81 \mathrm{a}$

65,125

$81 \mathrm{a}-\mathrm{c}$

$125,128,129,140$

República (Resp.)

II, $363 \mathrm{c}-\mathrm{d}$

127.

II, 364 b-c

II, $364 \mathrm{e}$

II, 378 a

II, 379 a

V, 449 c

V, 451 a

124,127

123, 128

127,128

132

86

130

177

VII, 528 b

81, 193

VII, $531 \mathrm{a}-\mathrm{d}$

81

VII, 531 c

193

$560 \mathrm{~d}-\mathrm{e}$

127

$\mathrm{X}, 600 \mathrm{a}-\mathrm{b}$

81

$\mathrm{X}, 608 \mathrm{~d}$

139

X, 620 c

156

Timeu

$56,121,152,153,176$, 177, 199204

$35 \mathrm{~b}$

199

$45 \mathrm{c}$

121

Plínio

Naturalis historiae (Hist. Nat.) Xxxiv $26 \quad 46$

Plutarco

Quaestiones convivales (Quaest. Conv.)

VIII. 7, 1

46

Vida de Numa (Numa). $8 \quad 46$ 
Porfírio (Porph.)

A abstinência dos animais (De Abst.)

2.28: 2

Vida de Pitágoras (VP)

1

7

9

18

49

$18-19$

30

19

$19-20$

$91,109,110,115,128,154$

20

21

$44,84,95,96$

26

44

147

30

122

90

37

53

53

56

34,98

44,181

96

$60-61$
Timon

$44 \mathrm{a} 8 \mathrm{dk}=$ aulus gellius; noctes atticae III

$17 ; 6$

176

Tito Lívio

$A b$ urbe condita

46

Xenócrates

Fr. 165 isnardi-parente

150

Xenófanes

$21 \mathrm{a} 1 \mathrm{dk}$

$21 \mathrm{a} 47 \mathrm{dk}$

$21 \mathrm{a} 52 \mathrm{dk}$

113

$21 \mathrm{~b} 7 \mathrm{dk}=\mathrm{d}$. L. Vitae VIII. 36

112

$21 \mathrm{~b} 19 \mathrm{dk}$

113

21 b 27-29; $33 \mathrm{dk}$

Proclo (Procl.)

Comentário ao Timeu (In Tim.)

Sículo; Diodoro (diod. Sic.) - cf. Diodoro Sículo

Siriano

Comentário à Metafísica de Aristóteles

(In Met.)

Sófocles (Soph.)

Electra (E1.)

Teofrasto (Theophr.)

Metafísica (Met.)

$58 \mathrm{~b} \mathrm{dk}$

Tertuliano

De anima pl 2: col. 697-701

Timeu de Locros (Lócres)

Schol. In Phaedr.: 279c = FgrHist: 566

f. 13

D. L. Vitae VIII 1085. 


\section{INDEX NOMINVM}

Abaris: 68, 215

Accame, S.: 97

Achtemeier, P. J.: 93, 94

Acron de Acragas: 179

Adimanto: 86, 87, 132

Adonis: 64

Adrasteia: 129, 130

Aglaofemo: 47, 48

Agostinho: 47

Alderink, L. J.: 135

Alcmeão: 78, 80, 103, 115

Alexandre de Afrodísia: 168, 186

Alexis: 92, 94

Alesse, F.: 150, 153, 155, 156

Alfieri, V.E.: 53, 149

Ambrósio: 47

Anaxágoras: 40, 57, 74, 186, 196-198

Anaximandro: 28; 40; 113; 119; 198

Anaxímenes: 40; 111

Antifonte: 4

Antíoco de Ascalon: 180

Antístenes: 49, 97

Apolo: 68, 121, 147, 148

Apolônio de Tiana: 49, 84, 86, 218

Aquiles: 147

Arcesilau: 180

Aristóteles: 15, 17, 18, 26, 27, 33, 37, 42, 50, 52, 54-57, 60, 62, 67, 69, 73, 77, 79, 82, 86, 92, 93, 98, 101-104, 110, $113,115,121,131,132,148-150$, 152-156, 158, 161, 163-174, 176, 179-189, 195, 196, 198, 201-204, 206, 208, 211
Aristóxeno: 30, 33, 35, 36, 43, 46, 73, $78,88,90,97,99,146,167,180$, 192, 219

Arquelau: 40

Arquitas (cf. Pseudo-Arquitas): 13, 27, 43, 56, 57, 62, 78, 80-82, 92, 101, $102,121,131,155,158,166,172$, 172, 178, 179

Baco (cf. Dioniso): 137

Balaudé, J.-F.: 114

Baldi; B.: 47

Barbera, A.: 193

Barnes, J.: 195

Bechtle, G.: 29

Becker, O.: 59

Bellido, A. M.: 92

Bernabé, A.: 19, 64, 65, 111, 123, 124, 126, 129, 130, 132, 134, 135, 137, 138, 139

Bertermann, W.: 3249

Bestor, T.W.: 135

Betegh, G.: 64, 110

Biondi, G.: 146-148

Bluck, R. S.: 123, 125

Boas, G.: 15

Boeckh, A.: 23-26, 28, 162, 174, 177, 196, 217

Boyancé, P.: 123, 217

Brisson, L.: 19, 49, 78, 123, 124, 176

Burkert, W.: 14, 15, 16, 24, 26, 30, 32, $33,53,56,59-62,64,68,69,73-75$, $78,82,83,84,86,90,91,92,95$, 97, 99-103, 105, 110, 112, 114, 
$115,117-119,120,121,124,126$, 131, 132, 134-136, 139, 142, 144, 146-148, 150, 154, 155, 162, 164, $166,168,169,173,174,175,177$, 178, 179, 180-182, 184-189, 192, 193, 195-197, 199, 201-206, 209, $215,216,218,219,221$

Burnet, J.: 15, 34-39, 54, 56, 69, 101, 110, 112, 162, 168, 169, 172, 177, 179, 193, 195, 208

Burnyeat, M. F.: 122

Bywater, I.: 162, 177, 195, 201

Cálicles: 130, 131

Calogero, G.: 30, 54

Cambiano, G.: 204, 231

Cameron, A.: 56

Capparelli, V.: 45

Carcopino, J.: 64

Casadesús, F.: 65

Casadio, G.: 111, 112, 123, 126, 130, 131, 133-135, 137, 138, 140, 144

Casertano, G.: 13, 48, 53, 59, 112, 121, 148, 150, 153, 168, 170, 193

Casini, P.: 48

Cebes: 139, 205

Centrone, B.: 15, 24, 28, 29, 42, 48, 49, $51,59,77,78,80,82,83,85,91-93$, $98,99,102,103,112,123,144,148$, $152,155,168,171,173,175,177$, 180, 181, 184-186, 188, 193, 199, 216, 217

Cherniss, H.: 39, 53-56, 66, 69, 150, 153, 161, 162, 164-167, 169, 171, $172,174,183,196,208$

Chevitarese, A. L.: 92

Ciaceri, E.: 139

Cícero: 44, 46, 219

Clearco: 73

Clemente de Alexandria: 98, 112, 133

Clínias de Tarento: 87

Coelho; M. C. M. N.: 205

Colli; G: 110

Collobert; C.: 55, 56

Copérnico, Nicolau: 220, 221

Corax: 179

Cornelli, G.: 26, 50, 67, 97, 103, 110, $113,115,140,142,144,203,205$

Cornford, F. M.: 15, 36-40, 54, 69, 115, $140,165,166,168,170$
Conybeare, F. C.: 86

Corssen, P.: 147

Crátino: 113

Creese, D.: 200

Cumont, F.: 64, 70

Curd, P.: 201

Cusa, Nicolau de (Cusano, Nicolau): 47

Damascio de Damasco: 195

Damon: 88, 89

Darwin, C.: 37

Deméter: 144

Derveni, Papiro: 64, 124, 126-128, 136, 157, 189

Deubner, L.: 32,100

Delatte, A.: 33, 42, 43, 59, 69, 78, 94, 101, 147, 158, 169

Demétrio de Magnésia: 175

Demócrito: 40, 53, 78, 115, 149, 158, $164,166,178$

Detienne, M.: 14, 62-64, 66, 70, 91, 140

De Vogel, C. J.: 24, 30, 31, 34, 42, 45, 49-51, 88, 110, 126, 135, 137

Dicearco: 33, 43, 49, 73, 110, 146

Diels, H. A.: 30, 31, 33, 42, 54, 69, 115, $153,179,195$

Diès, A.: 130

Dike: 130

Dillon, J. M.: 180, 181

Diocles de Magnésia: 32

Diodoro Sículo: 111

Diógenes Laércio: 15, 32, 33, 40, 44, 46, $77,79,84,85,93,103,113,147,175$

Dion: 175

Dioniso (cf. também Baco): 134, 139, 144, 175

Dioniso Zagreu: 65

Dionísio de Siracusa: 88, 89

Dionísio II de Siracusa: 94, 95

Diodoro Sículo: 111

Dodds, E. R.: 112, 114, 126, 135, 136, 219

Döring, A. G. P.: 35

Drosdek, A.: 115

D. S. M.: 42

Dubois, L.: 134

Ecfanto: 78, 172

Eleusis: 127

Empédocles: 29, 30, 38, 50, 66, 78, 110, 114, 116, 120-122, 125, 129, 130, 132, 141, 144, 156-158, 186, 197 
Epicuro: 40, 219

Epimênides: 27, 113, 215.

Espeusipo: 57, 142, 167, 180, 181, 185

Ésquilo: 130

Estobeu: 136, 181

Eudemo: 74

Eudoro: 180

Eudoxo: 78

Euforbo: 146-148

Eumolpo: 127

Eurífamo: 89

Eurípides: 123, 128, 130, 134

Eurito: 78, 165, 166, 168, 178, 202, 205

Eusébio de Cesaréia: 61

Favorino: 32

Federico, E.: 140, 147

Feldman, L. H.: 51, 63

Ferécides: 118, 119

Ferrero, L.: 45, 48, 217

Ferwerda, R.: 135-138

Festugière, A. J.: 64, 66, 219

Ficino; M.: 47, 48

Filodemo: 124

Filolau: 13, 15, 18, 23, 24, 26, 27, 30, $31,38,48,57,60-62,66,78,79$, 80, 92, 101-103, 114-117, 119, 121, 131-136, 138, 142, 155, 158, 161-163, 167, 172-180, 182, 187, 188, 190, 193-206, 208-211, 218

Fílon (Filo): 91

Filostrato: 86

Fintias: 88,89

Fócio: 98, 179, 180

Frank, E.: 32, 56, 57, 59, 69, 101, 131, 132, 149, 161, 162, 166, 167, 169, 174, 193, 195, 199, 208

Gaiser; K.: 74, 83

Galileu Galilei: 211, 220

Gazzinelli G. G.: 127

Gemelli, M. L. M.: 53, 66, 67, 68, 75, $76,93,115,119,122,128,149,150$, 197

Gigon, O.: 172

Glauco: 139, 193

Glauco de Régio: 149

Gomperz, T.: 54, 182

Górgias: 49, 50, 197

Gosling, J.: 193

Goulet, R.: 84
Graf, F.: 134

Guilherme de Moerbeke: 185

Guthrie, W. K. C.: 13, 15, 36, 37, 39, 40, $42,69,101,110,114-116,131,135$, $137,150,153,163,170,216$

Hades: 65, 95, 110, 127, 131, 135, 141, $142,147,149,149$

Hadot, P.: 67

Heathm, T.: 16

Hecateu: 119

Hegel, G. W. F.: 16, 28, 55, 216

Heidel, W. A.: 179

Hera: 89, 119

Heráclides Pôntico: 33, 73, 147, 148, 216

Heráclito: 15, 30, 31, 75, 112, 118-120, 122, 136, 145, 157, 196, 197

Hermann, G.: 123

Hermes (cf. também Mercúrio): 48, 147

Hermipo: 175, 176

Hermodamante: 62

Heródoto: 17, 65, 110, 111, 119, 124, 134, 143-146, 156, 158, 199

Hesíodo: 62, 63, 79, 113, 119, 155

Hipaso: 87, 92, 99, 100, 101, 172

Hipócrates de Quios: 60, 199, 205, 206

Huffman, C. A.: 14, 16, 26, 59, 61, 62, 66, 74, 78-81, 90, 92, 93, 101, 102, 103, $112,114,115,122,131,132,155$, 162, 163, 164, 173-179, 181, 182, 185-188, 192, 195, 196, 198, 199, 201-206, 209, 211, 216, 236, 238

Íon de Quios: 118

Isnardi Parente M.: 150, 180, 181, 183, 184

Isócrate: 92, 143-145, 158

Jacoby; F.: 87

Jaeger, W.: 43, 73, 83

Jâmblico: 15, 16, 23, 25, 30-32, 34, 44, $46,48,49,78,79,83-85,87,88$, 90-92, 95-103, 105, 141, 172, 176, 178, 180, 211, 218

Jiménez San Cristóbal, A. I.: 126

Joost-Gaugier, C. L.: 48

Josefo, Flávio: 91

Kahn, C. H.: 13, 40, 112, 119, 121, 145, 184, 185, 189, 195, 198, 199, 201, 220

Kahrstedt, U.: 42 
Kees, H.: 144

Kepler, J.: 220, 221

Kerferd, G. B.: 51, 63

Kern, O.: 64, 110, 112, 130

Kerényi, K.: 111, 147

Kingsley, P.: 14, 16, 64-68, 70, 114, 119, 121, 124, 126, 204, 219

Kirk, G. S.: 144, 162, 166

Knorr, W. R.: 205

Kouremenos, T.: 64

Krämer, H.: 74, 183

Kranz, W.: 30, 31, 54, 118, 120, 153, 195

Krische, A. B.: 42

Laks, A.: 55, 64, 127, 216

Laks, A.: 64, 127

Latâncio: 47

Lee, H. D. P.: 53

Leszl, W.: 180

Leucipo: 40, 164, 166

Lévy, I.: 32, 64, 110, 146, 162, 195

Lísis: 89

Lloyd, G. E. R.: 204

Long, H. S.: 112, 126, 144

Luciano de Samósata: 87

Macris, C.: 94, 120

Maddalena, A.: 112, 153, 175

Mamerco: 28

Mamerto, Claudiano: 133

Mansfeld, J.: 55

Martin, A.: 66

Masaracchia, A.: 123

May, J. M. F.: 42

Meattini, V.: 131

Médici, Cosimo de: 47, 48

Melanipe: 128

Mele, A.: 48, 96, 144

Menelau: 147, 148

Menestor: 80

Mênon (personagem platônico): 65, $125,126,128,129,140,142$

Mênon (discípulo de Aristóteles, a quem se atribui o Anônimo Londinense): 78, 176

Mercúrio (cf. também Hermes): 47, 48

Meriani, A.: 81

Migliori, M.: 190, 191

Minar Jr.; E. L. $\quad 14 ; 44 ; 45 ; 59 ; 62$; $78,83,86,101$
Mirandola - cf. Pico della Mirandola

Mnemosýne: 65, 141, 142

Mnesarco: 119, 146

Momigliano, A.: 84

Mondolfo, R.: 15, 24-28, 45, 52-54, 73, 80, 109-111, 115, 116, 118, 120, $121,122,144,149,150,153,162$, 169,173

Morgan, M. L.: 68

Morrison, J. S.: 144

Most, G. W: 64, 127

Mourelatos, A.: 201

Murari, F.: 37

Museu: 123, 127, 128

Musti, D.: 48, 49, 97

Nauck, A.: 128

Neantes: 62, 95, 121

Nicômaco: 32, 85, 95, 167, 176

Nigídio Fígulo: 219

Nietzsche, F. W.: 29, 32

Nilsson, M. P.: 135, 137

Nucci, M.: 66, 120

Nussbaum, M.: 166

Numa Pompílio: 46

Numênio de Apaméia: 180

Obbink, D.: 64

O'Brien, D.: 68

Olimpiodoro: 111

O'Meara, D.: 181

Orfeu: 47, 48, 118, 123, 128, 135

Ovídio: 46, 122

Parmênides: 29, 37, 40, 52, 53, 54, 66, 67, 74, 78, 142, 185, 186, 196,199, 201

Pascal, B.: 122

Pátroclo:147

Peixoto, M.: 115

Perséfone: 65, 125, 137

Petrarca: 47

Philip, J. A.: 31, 33, 42, 50, 83, 85, 86, $97,114,116,122,150,175,193$, 205

Pico della Mirandola, G.: 47, 48, 220

Pierris, A. L.: 64

Píndaro: 125, 126, 129

Pitágoras: 15, 16, 23, 27-31, 33-40, 42-51, 59, 61, 62, 64, 68, 73, 75, 78-82, 84, 85, 88-103, 109-116, 118-122, 141, 144-149, 157, 158, 
167, 172, 173, 175, 178-181, 192, $215,216,219,220,221$

Pitts, W.: 57

Platão: 15, 17, 24, 34, 40, 41, 47, 48, 54-60, 62, 65, 67, 69, 73, 74, 78, 80-82, 86, 87, 92, 104, 111, 115, $116, \quad 121-124, \quad 126-134,137$, 139, 140, 142, 148, 150, 152, 153, $155-158,162,165,167,169$, 175-177, 179-187, 189, 192, 193, 195, 196, 198, 200, 201, 204, 209, 210, 216

Plotino: 47, 112

Plínio: 46

Plutarco: 46, 124

Polemarco: 86

Pollard,J. R. T.: 63

Pompeu Trogo: 31

Porfírio: 15, 30, 32, 34, 44, 46, 49, 62, 84, $85,90,91,95,96,98,105,109,110$, $115,128,154,157,158,161,180$

Prier, R. A.: 136

Prontera, F.: 48

Proclo: 149, 181, 184, 185

Proros de Cirene: 87

Protarco: 191

Pseudo-Arquitas (cf. também Arquitas: 92 Pugliese Carratelli, G.: 64, 65, 110, 123, $126,128,136,139,141,142$

Rathmann, G.: 110, 112, 121, 135, 143, $144,150,153$

Raven, J. E.: 39, 54, 144, 162, 166, 170, 195

Reale, G.: 55, 74, 155, 183

Redfield, J.: 140

Reinhardt, K.: 54

Rey, A.: 54, 169

Rey Puente, F.: 189

Riedweg, C.: 14, 68, 83, 94, 101, 112, $113,118,121,122,135,147,129$, 216, 217, 220

Ries, K.: 145

Robbiano, C.: 201

Robbins, F. E.: 204

Rocconi, E.: 200

Rohde, E.: 32-34, 49, 69, 78, 83, 89, 99, $101,110,115,135,143,147,215$

Rostagni, A.: 15, 45, 49-51, 88, 112, $113,115,122$
Salas, O. D. A.: 57,59

Sandbach, F. H.: 118, 120

Santillana, G. de: 57

Sassi, M. M.: 40, 141

Sátiro, 175

Scarpi, P.: 121

Schleiermacher, F.: 28

Schofield, M.: 144, 162, 166

Segonds, A. P.: 49, 78

Seltman, C.: 42

Símias: 115,205

Siriano: 8, 181, 184

Sófocles: 148

Spinelli, M.: 162

Striker, G.: 190

Stroumsa, G. G.: 66

Szlezák, T. A.: 74, 92, 183, 184

Tambrun-Krasker, B.: 48

Tannery, P.: 52-54, 59, 69, 101, 135, $165,204,205$

Tate, J.: 43

Taylor, A. E.: 56, 69, 169, 193

Teano: 78, 94, 181, 184

Telauge: 40

Temistocleia de Delfos: 192

Teodoro de Cirene: 60, 78

Teofrasto: 33, 124, 181, 185

Tertuliano: 47

Thesleff, H.: 24, 31, 50, 51, 57, 79, 92, 98, 177,179, 181

Thomas, H. W.: 136

Timão de Fliunte: 113

Timeu de Locros (Lócres): 176

Tímica: 78, 94, 95

Timon: 176

Tísias: 179

Tito Lívio: 46

Tortorelli Ghidini, M.: 64, 110, 124, 134, 137, 142

Toynbee, A. J.: 83

Trabattoni, F.: 183

Trásilo: 149

Trépanier, S.: 121, 122

Tucídides: 37

Ulisses: 49

Ustinova, Y.: 110

Van der Waerden, B. L.: 59

Vegetti, M.: 80, 81, 124, 127, 140

Viano, C.: 66 
Vidal-Naquet, P.: 63

Vinogradov, J. G.: 134

Vlastos, G.: 132, 183

Von Fritz, K.: 14, 33, 43-45, 59-61, 85, 100, 111, 162

Wehrli F.: 73, 99, 110, 147, 192, 216, 219

West, M. L.: 66, 121, 123, 127, 134

Wiersma, W.: 175

Wilamowitz Moellendorf, U. Von: 56, $115,123,126,131,132,135,136$, 143, 176

Wilson, B.: 84

Wittgenstein, L.: 221

Xenócrates: 150, 180

Xenófanes: 15, 30, 52, 112-115, 117, $119,132,157$

Zalmoxis: 110, 144, 146

Zeller, E.: 15, 21, 24-32, 34, 41-43, 45, 50, 52-54, 57, 59, 60, 69, 70, 73, 77, 80, 104, 109-112, 115, 116, 118, 120-122, 144, 149, 150, 153, 161, $169,173,178$

Zenão: 37, 40, 52, 53

Zeus: 138

Zhmud, L. J.: 15, 28-30, 59, 77, 78, 83, 97-99, 101, 134, 135, 144, 162-164, 167, 171-173, 208

Zoroastro: 47

Zósimo de Panópolis: 66

Zucconi, M.: 49

Zuntz, G.: 64, 121 


\section{INDEX RERVM}

Academia; primeira (cf. também Média academia): 47, 60, 62, 74, 142, 148, 167, 180, 184, 193

Acusma; Acusmata; Akoúsmata;

Acusmáticos: 15, 30, 34, 35, 59, $60,78,82,83,92,93,98-102,105$, $117,121,136,168,217-219$

Adrasteia; lei de: 129, 130

Alexandria: 91

Alimentação (cf. também Carne;

Vegetarianismo): 63, 122

Alma (Psyché; cf. também Imortalidade;

Metempsicose; Palingênese;

Períbolos; Transmigração): 26,

27, 60, 64, 88, 90, 91, 109-120,

122-141, 143, 144, 146, 147, 149,

150-154, 156-158, 164, 167, 189,

$204,215,218,220$

Alquimia: 66

Anamnese; Anamnésis (cf. também Memória; Mnemê; Mnemosyne): $125,128,140-142,149,157$, 218

Animal; Animais: 35, 63, 88, 91-92, 114, 146-147, 155

ÁPEIRA; Apeíron (Ilimitado; cf. também

Limitante; Limite; Peiránonta;

Peperasménon; Péras): 185, 186, 191, 192, 196

Apócrifos (cf. tambémPseudoepigráficos):

$24,51,79,92,180$

APORĹA: 82, 104, 181, 189

Apóstatas; Apostasia: 53, 84, 89, 105
Ar (cf. também. Atmosfera; Respiração): 111, 115, 143, 149, 176, 192, 198

ARCHAÍ; Arché (cf. também Princípio): 37, 114, 164, 167, 172, 196, 198-199, 203

ARIthMos (cf. também Aritmética; Aritmologia; Número): 166, 171

Aritmética (cf. também Arithmos; Aritmologia; Número): 81, 176, 202

Aritmogeometria (cf. também Arithmos; Aritmologia; Número): 47, 62, 203, 218

Aritmologia (cf. também Arithmos; Aritmética; Número): 59, 204

Arqueologia; Arqueológico(s): 42, 48, 64, 66, 70, 74, 75, 96, 114, 124

ARTIOPÉRITTON (cf. também Contrários; Opostos): 187, 202

Astrologia: 204

Astros; Astronomia: 30, 81, 98, 109, 128, 193

Atenas: 47, 144, 176, 195

Atmosfera (cf. também. Ar; Respiração): 153

Атоміsmo; Átomo(s): 37, 53, 115, 140, 149, 150, 152, 164, 165, 166

Bens; comunhão ou partilha de: 83, 85-88, 95-97, 105

Bíos (cf. também Vida): 35, 67, 70, 78-82, 84, 85, 87, 89, 97, 98, 102, $105,117,124,172,218-220$ 
Cabala: 48

CARne; abstinência de (cf. também Vegetarianismo): 35

CHORISMÓs: 184, 187, 209

Ciclo(s) (cf. também Kíklos): 35, 110, 111, 130, 204

CiênCIA: 26, 34-39, 52, 57, 59, 60, 75, 76, 81, 92, 98, 102, 104, 155, 203, 218-221

Cirene: 60, 87

Comédia Ática InTERMEdiária: 30

Contrários (cf. também Artiopéritton; Opostos): 167

Corinto: 88

Corpo (cf. também Sôma): 88, 90, 110, 111, 115, 116, 129-140, 143, 147, 152-154, 156, 164, 168, 176, 188, 191, 197, 203

Corpus Hermeticum: 48

Cosmologia: 38 , 52, 64, 80, 109, 121, 123, 130, 165, 188, 189, 196, 199, 200, 203, 210, 218

Creofiléus: 63

Crotona: 30, 42-45, 49, 51, 78, 84, 88, 94, 95, 100, 113

Culpa: 133,139

Culto: 60, 83, 88, 97, 104, 141, 146, 148, 168, 219

Cura; Curar (cf. também Medicina): $67,68,90,93,120,129$

DAÍMON: 63, 114, 116, 133

Delfos: 99, 136, 192

DESMOTÉRION (cf. também Sêma): 137

DíADE indefinida [ou indeterminada] (cf. também Dýas; aoristós): 155, 183-188, 194, 210

Dialética; Dialético (método): 125, 183, 184, 190, 191, 193, 194, 199

DIDASKALEION (cf. também Escola): 84.

Dionisismo: 65

DoKIMASíA: 85,89

DórIos; Dórico(s): 28, 31, 51, 132, 179 , 180

Dýas; aoristós (cf. também Díade indefinida [ou indeterminada]): 186

EducaçÃo: 28, 43, 81, 175

Egito; Egípcio(s): 47, 67, 97, 119 143-145

Eleatas; Eleática; Eleatismo: 37-39,
$52-54,69,78,196,198,201,210$

ElÉIA: 78

Elementos (cf. também Stoichéia): 38, $65,88,115,131,133,163,183,185$, 187, 188, 193, 200, 202, 218

Eleutherna; lâmina (s) de: 65, 142

ENTELÉCHEIA: 154

Entes matemáticos (cf. também Mathematikâ): 183

Eleutherna; lâminas (s) de: 65, 142

ENTELLA; lâmina (s) de: 142

EPIMÉLEIA: 120

Er; mito de: 153, 156

Escola (cf. também Didaskaleion): 24, $25,27,30,35,37,39,44,50,53,57$, $65,69,74,75,77,80,81,84,96,101$, $102,104,112,115,119,172,181$, 183, 195, 209, 216, 217, 219

Esotéricas (doutrinas); Esotéricos (ensinamentos): 83, 93, 123, 183, 197

Estoica (tradição); Estoicos 90,180

Esfera(s): 27, 92, 122, 161, 199, 203

Essênios: 64, 91

Etimologia: 111, 135-139, 157, 168

Eurístico (método): 189, 190

ÉTHOS; Ética: 28, 3,4 64, 65, 67, 88, 90, $96,110,113,117,131,138,140$, $141,149,157,192,216$

Física: 37, 82, 102, 111, 150, 187, 188, 202, 203

Fogo: 121, 167, 172, 173, 186, 190, 198, 199, 203

Fogo CENTRAL: 27, 161

Genealogia; Genealógico(a): 16, 48, $50,79,101,104,120,147,179,243$

Geometria: 81, 98, 203, 205, 233

Gnômon(s): 202.

Grandeza (cf. também Mégethos): 113, 121, 165, 167, 199, 200, 203.

GrÉcia: 28, 42, 43, 45, 47, 48, 43, 60, $66,68,75,84,91,95-97,109,110$, $119,129,139,140,142,143,146$, 179,204

Hades: 65, 95, 110, 127, 131, 135, 141, $142,147,149$

HARMÓCHTHE (Acordo; cf. também Harmonia): 199

Harmonia (cf. também Medida; 
Métron; Isonomia; Proporção): 27, 99, 115, 116, 121, 122, 133, 141, 161, 163, 190-193, 197-203, 205, 206, 210, 211, 218, 220

Helenismo; Helenística(o): 13, 31, 51, 64, 67, 79, 80, 90-93, 95, 178, 181, 199, 209, 218, 219

HeTAIRÍA: 83, 97, 104

HipocráticA; medicina (cf. Medicina): 168, 204, 205

Hipponion; lâmina (s) de: 141

Номоіо́мАТА: 60, 168

IDION: 80

Ilimitado(s) (Ápeira; Apeíron; cf. também Limitante; Limite; Peiránonta; Peperasménon; Péras): 115, 183-188, 190, 192-206, 210, 211

ImitaçÃo (cf. também Mímesis): 88, 129, 164, 165, 167-170, 208

InFinito (cf. também Ilimitado): 190, 198

Imortalidade (cf. também Alma; Metempsicose; Palingênese; Psyché; Transmigração): 64, 65, 107, 109-111, 113-127, 129-131, 133-135, 137-147, 149, 151, 153, 155-158, 161, 167, 208, 211, 218, 220

InCOMENSURABILIDADE; doutrina da: 92, 205, 206

Isonomia; Isonomía: 95, 149

ItÁLIA; Itálica; Itálicos: 28, 38, 40, 44, 46-48, 50, 52, 67, 76, 77, 95, 96, 102, 104, 120, 130, 131, 135, 138, 144, 182, 186, 216, 219

Jônios; Jônico(s): 28, 31, 38, 40, 52, 60, 76, 104, 111, 146, 173, 198, 216, 219

KATÁBASIS: 95, 146

KATHÁRSIS: (cf. também Purificação): $34,35,61$

KíKLOS (cf. também Ciclo): 110

KoInonín: 29, 34, 43, 44, 65, 80, 82, 83, 87, 89, 94, 96-98, 101, 105, 126, 139-141, 217

KOPIDES: 31

Kósmos: 30, 196

KRÁSIS: 153
LÂMINAS [de ouro]: 64, 65

Lестіо: 16, 24, 29, 31, 34, 51, 55-57, 65, $66,77,115,128,137,139,164,169$, $174,178,179,181,182,184,185$, 187, 195, 204, 205, 209, 218

Limitante; Limite (Peiránonta; Péras; cf. também Ápeira; Apeíron; Ilimitado; Peperasménon): 115, 165 , 188, 190-206, 210, 211

Locros (Locrés): 96, 176

LóGOI: 49-51, 75, 88, 197

Magna Grécia (cf. também Itália): 28, 42, 43, 45, 48, 53, 66, 75, 84, 95-97, 129, 139, 140, 142, 143, 179

Mareótida: 91

Matemática: 28, 38, 43, 52, 57, 59-62, 81, 82, 92, 99-102, 105, 109, $116,119,128,142,150,155,158$, $161-165,167,169,179,180,183$, 189, 195, 201, 204, 206, 208, 210, 211

Matemáticos; Mathematikós: 34, 35, 60, 92, 98-103, 105, 121, 206, 217, 218

MATHEMATiKÁ (cf. também entes matemáticos)

Média academia (cf. também Academia; primeira): 180

Medicina (cf. também Cura; Curar): 115, 116, 128, 168, 203-205

Medida(s) (Métra; Métron; cf. também Harmonia; Isonomia; Proporção): 149, 191, 193, 206

MÉGETHOS: 199, 203

Memória; Mnemê; Mnemosýne (cf. também Anamnese; Anamnésis): $38,49,65,88,89,95,110,112,113$, $115,120,123,140-142,147157$, 175,218

Metaponto: 78, 95, 100, 148

Metempsicose; Metempsychósis (cf. também Alma; Imortalidade; Palingênese; Psyché Transmigração): 47, 56, 64, 91, 92, 105, 107, 109-117, 119, 121-131, 133, 135-145, 147, 149, 151-158, 217, 218

MÉTHEXIS (cf. também Participação): $167,169,182$ 
MÉTRA; Métron (Medida; Proporção; cf. também Harmonia; Isonomia): 193

Milagres (cf. também Mirabilia): 93, 94, 148

MímESIS (cf. também Imitação): 167-170, 182

MIRABILIA (cf. também Milagres): 148

Misticismo: 37, 59, 60, 64, 116, 204, 211

Mistura: 90, 136, 188, 192, 193, 201, 202

Moral: 27, 28, 43, 50, 79, 118, 92, 95, 124, 128-130, 138-140, 153, 157, 219

Mulheres: 28, 50, 78, 79, 86, 87, 94-96, 125, 126, 140

MúsicA: 28, 43, 60, 81, 98, 99, 191-193, 199-201, 203, 204, 210

MÝthos; Mýthoi; Mythologia: 126, 153, 155, 158, 197

Neopitagóricos; Neopitagorismo: 26, 29, 47, 66, 70, 181, 219

Neoplatônicos; Neoplatonismo: 32, 66, 73, 179-181, 211, 218, 220

Número(s) (cf. também Arithmos; Aritmética; Aritmologia): 17, 18, $27,29,30,52,59,60-62,77,79,80$, $84,98,99,130,150,161,163-174$, 178, 181-189, 191, 193, 195, 196, 200-211. 217, 218, 220, 221

Numismática: 42

Numerologia: 59-61, 204, 205, 207, 218

OMAKOEÎN: 96, 97

Opostos (cf. também Artiopéritton; Contrários): 37, 81, 99, 100, 116, 121

Oráculos Caldaicos: 48

Orficos; Orfismo: 64, 65, 70, 75, $118-120,123,124,126,128,129$, 130, 133-136, 139, 140, 142-144, $155,157,158,189$

Oriental; Oriente: 26-28, 48, 57, 64, $66,70,119$

PAIDÉLA: 81

PAIDEUTIKón; Politikón; Physikón: 31

Palingênese (cf. também Alma; Imortalidade; Metempsicose; Psyché; Transmigração): 111, 120,
$122,125,147,157,158$

PAPiro(s): 64, 66, 124, 126-128, 136, $157,176,177,189$

Parentesco universal: $91,109,128$, 154,158

Participação (cf. também Méthexis): $28,86,164,165,167,183$

Pelinna; lâminas de: 65, 137

Pentagrama: 87

PEIRÁNONTA (Limitante; cf. também Apeíron; Limite; Ilimitado; Peperasménon;Péras): 196

PEPERASMÉNON (Delimitado; cf. também Apeiron; Limitante; Limite; Ilimitado; Peiránonta; Péras): 186, 187, 196

PÉRAS (Limite; cf. também Apeíron; Ilimitado; Limitante; Peiránonta; Peperasménon): 186, 188, 192, 196

PERÍBOLOS: 137

Peripatético(s): 30, 33, 49, 73, 90, 100, 147, 175, 181, 218

Petélia; lâmina (s) de: 142

Pharsalos; lâmina (s) de: 142

Pherai; lâminas de: 65

PHILÍl; Phílôn: 86, 88, 89, 105

Platonismo: 47, 56, 74, 112, 171, 179-182, 184, 189, 208, 209

Poetas gnômicos: 27

Políades (cf. Pólis): 91, 95, 139, 140

Políades (festas religiosas): 91, 139

Polis; Polizen: 96, 140

Política; Político(s): 13, 14, 28-30,33, 41-46, 48-51, 62, 69, 75, 83-85, 90, 96-98, 103, 105, 109, 123, 129, 139, 140, 162, 217, 220

PRÁGMatA; Pragmatéia: 100, 163, 168, 184, 199, 215

Pré-Platônicos: 29, 40, 69, 114, 116, 124,174

PrÉ-socráticos: 15, 17, 18, 24, 26, 28, $30,39,53-56,58,66,68,69,74,75$, $80,93,114,128,136,166,168,176$, 178, 184, 188-190, 196, 197, 199, 201, 208-210, 216, 217

Princípios (cf. também Archaî): 26, 34, $35,65,74,79,114,141,164,167$, 169, 170, 181-191, 193, 196-198, 201, 203, 204, 206, 208, 210, 211, 
218

Procriação (cf. também Reprodução; Sexo): 95

Proporção (cf. também Harmonia; Isonomia; Medida; Métron): 26, 84, 131, 141, 168, 203

Protopitagorismo: 15, 17, 18, 43, 61-63, 68, 70, 81, 82, 93, 104, 105, $110,114,117,120,121,122,141$, $148,152,155,156-158,161,168$, 169, 171, 209, 211, 216, 218, 219, 220

PsêPHOS; Pséphoi: 165, 202

Pseudoepigráficos (cf. também Apócrifos): 120, 123, 175, 177, 179, 181, 184, 195, 199, 209, 219

PSYCHÉ (cf. também Alma; Imortalidade; Metempsicose; Transmigração): 60, 111, 114-117, 131-134, 150, 215

Purificação (cf. também Kathársis): 34, 35, 120-122, 180, 215

Religião (cf. também Culto): 14, 26-29, 34-39, 41, 44-46, 51, 61-66, 69, 70, 75, 83, 84, 91, 97, 101-103, $110,113,116,117,121,123,126$, 131, 134, 138-140, 142, 149, 192, 217,221

Reprodução (cf. também Procriação; Sexo)

Respiração (cf. também Ar; Atmosfera): 153, 188

Ritmos (cf. também Rýthmoi): 68, 191, 193, 197

Roma; Romanos: 18, 45-48, 64, 69, 143

RÝTHMOI (cf. também Ritmos): 193

SACRIfício: 63, 91, 92, 127, 145, 146

SAmos; Sâmio: 46, 63, 84, 97, 119, 145

Segredo (cf. também Sigilo): 82, 87, 92, 93, 99, 148, 172, 192, 218

Seita: 35, 48, 83, 84, 91, 93, 95, 105, $134,149,217$

SÊMA (cf. também Desmotérion): 130-139, 157, 201, 203

Sexo (cf. também Procriação; Reprodução): 94, 95

Sigilo (cf. também Segredo): 84, 85, 92, 93, 105

SilêNCIO: 85, 92, 93, 97, 136, 143-145
Sete sÁbios: 27

SíbARIs; Sibari (cf. também Thurii): 42, 144

Sofistas; Sofística: 50, 55, 113, 191

SомA (cf. também Corpo): 130-135, 137-139, 157, 195, 204

STOICHÉIA (cf. também Elementos): 164,183

SÝmBOLA; Sýmbolon: 30, 34, 35, 60, 78, $82,83,90,93,98,102,134,136,141$

SYNGÉNELA: 128,136

SYSTÉMATA: 192

Tarento: 56, 78, 82, 87, 95, 205

Teвas: 205

TELEstaI: 135,139

Teologia: 47, 48, 62, 103, 113, 117

Terapeutas: 91

Thíasos: 83, 104

Thuri (cf. tabém Síbaris, Sibari): 65, 110,114

ThuriI; lâminas de: 65,110

Tradição: 13-17, 23, 25, 26, 30, 33-35, $38,39,45-50,52,56,57,59-61,65$, 66, 69, 70, 73-76, 78-81, 83, 84, 87-98, 100-105, 109-113, 117, 120, 122-124, 126, 129, 130, 132, 136, 137, 139, 144-149, 155-157, 161, $162,166,169,171-178,180,181$, 183-185, 189, 192, 196-198, 204, 208-211, 216-218, 220

TITÃs: 139

Tróia: 147

TRÓPOS; Monotrópos; Polýtropos: 29, 49, $50,81,87,102$

Transmigração (cf. também Alma, Imortalidade, Metempsicose, Palingênese, Psyché): 17, 27, 35, 109-112, 116, 122, 147, 153, 154, 156,158

Vegetarianismo (cf. também Carne; abstinência de): 91, 102, 124

VIDA (cf. também Bíos): 14-16, 20, 23, 27, 29, 32-34, 38, 43, 46-49, 61, 65, 67, 78-88, 90, 91, 98, 100-105, $111,114,116-118,125,127-132$, 134-136, 140, 146, 147, 149, 153, 154, 158, 172, 179, 190, 192, 199, 212, 216, 218, 219

XАм̃̃; Xamanismo: 61, 221 


\section{Volumes publicados na Coleç̧ão Humanitas SUPPLEMENTUM}

1. Francisco de Oliveira, Cláudia Teixeira e Paula Barata Dias: Espaços e Paisagens. Antiguidade Clássica e Heranças Contemporâneas. Vol. 1 - Linguas e Literaturas. Grécia e Roma (Coimbra, Classica Digitalia/CECH, 2009).

2. Francisco de Oliveira, Cláudia Teixeira e Paula Barata Dias: Espaços e Paisagens. Antiguidade Clássica e Heranças Contemporâneas. Vol. 2 - Linguas e Literaturas. Idade Média. Renascimento. Recepşão (Coimbra, Classica Digitalia/CECH, 2009).

3. Francisco de Oliveira, Jorge de Oliveira e Manuel Patrício: Espaços e Paisagens. Antiguidade Clássicae Heranças Contemporâneas. Vol.3-História, Arqueologia e Arte (Coimbra, Classica Digitalia/CECH, 2010).

4. Maria Helena da Rocha Pereira, José Ribeiro Ferreira e Francisco de Oliveira (Coords.): Horácio e a sua perenidade (Coimbra, Classica Digitalia/CECH, 2009).

5. José Luís Lopes Brandão: Máscaras dos Césares. Teatro e moralidade nas Vidas suetonianas (Coimbra, Classica Digitalia/CECH, 2009).

6. José Ribeiro Ferreira, Delfim Leão, Manuel Tröster and Paula Barata Dias (eds): Symposion and Philanthropia in Plutarch (Coimbra, Classica Digitalia/CECH, 2009).

7. Gabriele Cornelli (Org.): Representações da Cidade Antiga. Categorias históricas e discursos filosóficos (Coimbra, Classica Digitalia/CECH/Grupo Archai, 2010).

8. Maria Cristina de Sousa Pimentel e Nuno Simões Rodrigues (Coords.): Sociedade, poder e cultura no tempo de Ovidio (Coimbra, Classica Digitalia/ $\mathrm{CECH} / \mathrm{CEC} / \mathrm{CH}, 2010)$.

9. Françoise Frazier et Delfim F. Leão (eds.): Tychè et pronoia. La marche du monde selon Plutarque (Coimbra, Classica Digitalia/CECH, École Doctorale 395, ArScAn-THEMAM, 2010).

10. Juan Carlos Iglesias-Zoido, El legado de Tucídides en la cultura occidental (Coimbra, Classica Digitalia/CECH, ARENGA, 2011).

11. Gabriele Cornelli, O pitagorismo como categoria historiográfica (Coimbra, Classica Digitalia/CECH, 2011). 
Esta obra faz emergir da história da interpretação do pitagorismo os pontos essenciais que contribuíram para a formação de tantas e diversas leituras sobre o próprio pitagorismo. Gabriele Cornelli realiza uma atenta apresentação das fontes primárias e secundárias sobre os textos pitagóricos, dando contornos à vasta complexidade do tema. O livro se estrutura em quatro capítulos, que abordam, respectivamente, a história da crítica, de Zeller aos nossos dias; a questão metodológica do pitagorismo como categoria historiográfica; as teorias da imortalidade da alma e do número como elemento importante nas doutrinas pitagóricas.

Resultado de uma escolha consciente, anunciada deste a introdução, de evitar propor simplesmente mais uma interpretação do pitagorismo, essas páginas, ao contrário, procuram enfrentar a própria questão historiográfica que subjaz às diversas opções hermenêuticas de solução da "questão pitagórica", e que, de certa forma, reinventam-na continuamente. O percurso metodológico aqui proposto resulta numa imagem do pitagorismo que pretende escapar das várias tentativas de reduzir sua multifacetada complexidade nos moldes estreitos de uma categorização irremediavelmente insuficiente. O quebra-cabeça historiográfico da pesquisa sobre os pitagóricos revela-se um locus privilegiado para ensaiar uma revisão das práticas historiográficas comumente utilizadas para abordar a filosofia antiga em suas origens.

«Uma utilíssima ferramenta para quem queira orientar-se com uma maior consciência histórica e hermenêutica na intricada questão pitagórica.» Giovanni Casertano

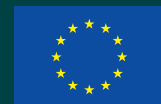

